\title{
THEORETICAL AND PREDICTED PERFORMANCE OF SELF-DRYING ROOF ENCLOSURES THROUGHOUT NORTH AMERICA
}

\section{By}

\author{
Rockford Boyer, B. Arch. Sc., BSSO \\ Bachelor of Architectural Science
}

Ryerson University, 2002

\section{A Major Research Project Presented to Ryerson University in fulfillment of the requirements of the Master of Building Science in the Department of Architectural Sciences}

Toronto, Ontario Canada, 2017

(C)Rockford Boyer, 2017 


\section{Authors Declaration}

I hereby declare that I am the sole author of this major research project. This is a true copy of the major research project, including any required final revisions. I authorize Ryerson University to lend this major research project to other institutions or individuals for the purpose of scholarly research.

I further authorize Ryerson University to reproduce this major research project by photocopying or by other means, in total or in part, at the request of other institutions or individuals for the purpose of scholarly research.

I understand that my major research project may be made electronically available to the public. 


\begin{abstract}
2017. Master of Building Science, in the Department of Architectural Sciences. Rockford Boyer Ryerson University
\end{abstract}

Roof enclosures traditionally have the largest litigation potential in the construction industry due to the complexities in the design and application. Development of a self-drying roof enclosure would potentially minimize the litigation and provide the additional benefits of increased resiliency, reduced financial burden for building owners, and minimal impact on the environment. Past studies have shown that the self-drying roof enclosures are viable, however, they must meet several performance characteristics. Oak Ridge National Laboratory developed six characteristics required to obtain a functional self-drying roof enclosure. New roofing materials on the market allow for the effective drying potential of enclosures when they become wet. WUFI 6.1 6.1 hygrothermal models were developed to determine if the theory of self-drying roof enclosures is valid in all ASHRAE climatic zones. Effective theoretical self-drying roof enclosure designs are highlighted for potential effectiveness spanning all climatic zones in North America. 


\section{Acknowledgements}

Very special thanks to the faculty in the Masters of Building Science program at Ryerson University, and especially to my supervisor, Dr. Ramani Ramakrishnan and $2^{\text {nd }}$ readers Dr. Umberto Berardi and Dr. John Straube (University of Waterloo).

Thank you to RDH, ROXUL Inc. and Cosella-Dorken who provided lab space, building materials and technical information which assisted with the testing and validation of my hygrothermal models.

Finally, thank you to my wife Vanja and our two children, Ana and Alexa, for their continued support throughout the Masters of Building Science program at Ryerson University. 


\section{Table of Contents}

Author's Declaration $\quad$ ii

Abstract iii

Acknowledgements $\quad$ iv

List of Tables $\quad$ vi

List of Figures vii

1.0 Introduction $\quad 1$

2.0 Literature Review 3

$\begin{array}{ll}3.0 \text { Methodology } & 11\end{array}$

4.0 Experimental Set Up $\quad 22$

5.0 WUFI 6.1 6.1 Simulation and Validation 25

6.0 Results and Discussion $\quad 31$

$\begin{array}{ll}7.0 \text { Conclusion } & 46\end{array}$

$\begin{array}{ll}8.0 \text { References } & 49\end{array}$

9.0 Appendix A - Increased Heat Loss Equation, Example and Solution 50

10.0 Appendix B - ASTM E96 Graph Results 52

11.0 Appendix C - Metal Deck E96 Sample Preparation 54

12.0 Appendix D - WUFI 6.1 Model Input Parameters 56

13.0 Appendix E - ASTM E96 Laboratory Results 59

14.0 Appendix F - Intentional Wetting of Roof Assemblies 79

15.0 Appendix G - Metal Deck Venting Strategies 85

16.0 Appendix H - Hygrothermal Model Profiles Throughout North America 86 


\section{List of Tables}

Table 1 - Predicted Drying Hours for NA Passive Self-Drying Roof Enclosure

Table 2 - Predicted Drying Hours for NA Active Self-Drying Roof Enclosure

40

Table 3 - Self-Drying Roof Enclosure - Climatic Zone Location Functionality

Table 4 - Average ratio of wet to dry thermal conductivity 


\section{List of Figures}

Figure 1 - Actual Drying Time of Original ORNL Self-Drying Roof Enclosure Designs 14

Figure 2 - ORNL Developed Modern Self-Drying Roof Isometric Drawing 15

Figure 3 - Predicted Drying Time of ORNL Self-Drying Roof Enclosure Designs 17

Figure 4 - Simulated "Ryerson" Self-Drying Roof Enclosure 18

Figure 5 - "Ryerson" Self-Drying Roof Enclosure Development and Simulation 19

Figure 6 - Hierarchy Diagram MRP Thought/Work Through Process 20

Figure 7 -Delta NovaFlexx for E96 (WVP) testing - Dry Cup Method 22

Figure 8 -Delta NovaFlexx ready for E96 testing (WVP) - Dry Cup Method 22

Figure 9-Materials for E96 (WVP) testing - Wet Cup Method 23

Figure 10 - Samples placed in a climate chamber at $25^{\circ} \mathrm{C}$ and $50 \% \mathrm{RH} \quad 23$

Figure 11 - Materials for samples of Metal Deck E96 (WVP) testing 24

Figure 12 - WUFI 6.1 Testing Matrix for Active and Passive Ventilation 25

Figure 13 - Passive vs. Active Ventilation Between Metal Deck Flutes 25

Figure 14 - WUFI 6.1 Calculation Including Key to Calculate Volume Percentage 28

Figure 15 - Section Through Proposed and Modeled Self-Drying Roof Enclosure 30

Figure 16 - RDH/ROXUL Self-Drying Roof Design Showing Sensor Locations 33

Figure $17-$ RDH/ROXUL Test Hut Roof Drying profile 34

Figure 18 - Test Hut vs. WUFI 6.1 Validation Wetting and Drying Profiles 36

Figure 19 - Section Through “Ryerson” Proposed Self Drying Roof 39

Figure 20 - Actual Moisture Content in Wood Wafer (RDH Test Hut) 43

Figure 21 - WUFI 6.1 Predicted Moisture Content in Mineral Wool 43

Figure 22 - Thermal Conductivity of Mineral Wool by Percentage of Moisture 45

Figure 23 - Moisture Content Increase in Mineral Wool (Winter Condensation) 46

Figure 24 - Potential Risk of Condensation at Metal Deck 47

Figure 25 - Moisture Storage Function for ROXUL's TopRock 51

Figure 26 - Moisture Storage Function -Cosella-Dorken's NovaFlexx 51 


\subsection{INTRODUCTION}

Moisture failures in flat roof building enclosures have had a negative impact on the construction industry for many decades. Moisture ingress has the potential to minimize the durability/resiliency of the enclosure, increase operational \& maintenance costs and be a nuisance to the building owner and the occupants. There is difficulty in quantifying the inclusive monetary impact of a water leak in a building whether the structure is residential, commercial or institutional; however, hard costs such as operational costs and/or replacement costs can be calculated with confidence. The driving objective on the development of a functional self-drying roof enclosure is to ultimately minimize the impact of a roof enclosure water leak on the environment, the performance and the financial burden of the building owner.

Moisture ingress into a roof enclosure can be induced into the system under three conditions: physical bulk water leaking through the water shedding membrane; roofing materials installed with built in moisture; and through diffusion or air leakage. Water leaking through the roofing membrane has been notably caused by common roofing damage functions such as blistering, incomplete laps, membrane punctures, membrane splitting, inadequate penetrations seals, membrane wrinkles, inadequate flashing including membrane abuse and neglect. Roofing materials have the potential to become moist or saturated due to the installation or storage of roofing materials under wet conditions. Moist or saturated materials which have low permeance membranes installed on either side do not have a high capacity for drying. Incomplete air/vapour membrane installed on the metal deck, has the potential to allow moisture to enter the roofing enclosure through diffusion and convection. Difference in pressures, whether vapour or air, can allow moisture laden vapour and air to enter the roof enclosure and condense on the underside of the roofing membrane under certain conditions. Standard construction practices will always allow for moisture through these three conditions therefore, introducing a system to promote self-drying will undoubtedly increase the durability, resiliency and thermal performance of the roof enclosure.

Complexities, mistakes and omissions in construction have a definite impact on the performance of buildings however, designing for failures, such as moisture ingress will increase 
the operational performance of buildings. Majority of roof enclosure failures can be categorized into three distinct modes of enclosure failure: $60-70 \%$ of the roof enclosure failures are the result of poor construction; $20-25 \%$ are a result of inadequate design; and the remaining $5-10 \%$ are the result of non-performing roofing materials. Although construction and material technologies have shown improvement over time, the speed of construction and the increased amount of value engineering will eventually negate the performance positives gained from the improved materials. Therefore, developing a self-drying roof which is easy to construct and is low cost, will be the ultimate objective of this research.

Researching and participating in many roof failure cases has indicated that the common thread for these failures is "continuous water ingress into the enclosure". There has been a general practice of constructing "budget" roof enclosures which meet the thermal performance criteria, but will not perform under moisture stressed conditions. The typical construction of Canadian "budget" roof enclosure includes; roof membrane, polyisocyanurate insulation, vapour retarder and roof deck substrate. The traditional American "budget" roof enclosure is similar to the Canadian roof enclosures; however, the vapour retarder may be removed. The performance of this type of roof in theory works well however, when moisture is added into these types of non-permeable roof enclosures, these systems under-perform. The underlying issue why these non-permeable roof enclosures work is because when moisture ingresses into the system, it takes a very long time to dry out. When moisture is present in the roof enclosure and does not have time or potential to egress, performance materials will absorb moisture and drastically reduce the overall performance of enclosure. Designing roof enclosures with the potential to dry utilizing permeable materials (strategically placed), will ensure optimum and long-lasting performance. Roof design for this research and simulation will include; roof membrane varying in colour, vapour permeable ROXUL TopRock Insulation, Cosella-Dorken Nova-Flex smart membrane and a semi-impermeable metal deck. This type of roofing enclosure will allow drying of the assembly to the interior conditioned space, where any added moisture can be handled by the mechanical systems. 


\subsection{LITERATURE REVIEW}

Roof membrane and roof component repairs, due to the ingress of moisture, are common occurrences in the construction industry over the course of the operation and the life cycle of a building or structure. When the wetting of the roofing enclosure is greater than the rate of drying the performance and durability of the roof enclosure becomes an area of concern. Key performance criteria that are at risk when roof enclosures become wet or completely saturated include; building occupant disruption, reduced enclosure durability, structural support issues, reduced thermal performance, membrane premature failure, IAQ etc. Controlling or mitigating these potential damage functions requires that the roof enclosure is adequately dry; however, if the enclosure does become wet, it should have the means to dry to the interior quickly. Oak Ridge National Laboratory (ORNL) has conducted an extensive study on the potential of selfdrying roof enclosures throughout the United States with reasonable success. At the time of this research and testing, ORNL was limited to typical roofing materials and constructions available at the time. Roofing techniques have not changed drastically over the past few decades, however, newer materials on the market can theoretically meet and surpass the requirements set out by ORNL to achieve a self-drying roof enclosure.

The research conducted by Oak Ridge National Laboratory in the mid-nineteen nineties led to the development of six self-drying roof enclosure requirements to possibly eliminate or minimize the damaging effects of moisture ingress. ORNL believed that the development of a self drying roof would result in a more sustainable and economical future for the United States of America. The 6 requirements were developed by ORNL and utilized in the design and construction of the roof enclosure and for the one-dimensional hygrothermal models. ORNL indicated that all 6 requirements were essential to meet the intent of a self-drying roof: however, these requirements were established from the materials that were currently on the market in the mid-nineteen nineties. The Pass/Fail criteria established for "Theoretical and Predicted Performance of Self-Drying Roof Enclosures Throughout North America" are acknowledged in the following 6 requirements identified by ORNL. 


\subsection{ORNL 6 Requirements for Self-Drying Roof}

1) Decreasing moisture content - the roof enclosure must decrease in moisture content over time. Exterior and interior conditions should not allow for increase upward vapour drive.

2) Moisture uptake due to condensation - the roof enclosure must not increase in moisture content over heating season due to condensation. Exception is allowed if the moisture content in critical layers does not impact roof enclosure performance.

3) No dripping to interior - the roof enclosure must not allow for bulk water to drip into the interior conditioned space below. Condensation on metal deck due to the high $\mathrm{RH}$ and colder air-conditioned spaces shall not occur.

4) Controlling vapour movement - the roof enclosure must account and minimize vapour diffusion and air leakage. A membrane shall be installed on the deck substrate to reduce the convection of water vapour and air.

5) Controlling water movement - the roof enclosure must use an absorptive layer to control and spread the bulk water over larger areas.

6) Downward drying - the roof enclosure must dry downward as quickly as possible after the roof membrane breach. Quick enclosure drying will minimize the potential oxidization and damaging of the structural components within the roof enclosure. 
ORNL completed 1,500 one-dimensional heat and mass flow transfer models to predict performance in the various climate zones around the United States of America. The 6 guiding principals identified in 2.1 were developed from the completion of these 1,500 hygrothermal simulations. The objective of the ORNL self-drying roof enclosure research was to identify functionality and to assess the applicability of these self-drying roof enclosure designs. These self-drying roof designs were based on the materials and construction practices readily available during that specific research period. ORNL believed that a self-drying roof enclosure would be a benefit to the environment, to the construction industry and to the building owner.

ORNL indicated that a roof enclosure's end of life is achieved when excessive moisture cumulates in the roof assembly and no longer has the capacity to provide the intended defence. A pre-mature end of life for a roof enclosure has a significant impact on the building owner's financial resources as well as a negative impact on the environment. ORNL initial intent of a selfdrying roof enclosure was to reduce and to maintain the United State's valuable resources. A comprehensive study by Powel and Robinson (National Institute of Standards and Technology) on the drying potential of roof assemblies was established in the early 1970's and was a value resource for ORNL research. The findings from Powel and Robinson's research stated that "the most practical and economical solution to the problem of moisture in insulated flat-roof constructions is to provide a design that would have in-service self-drying characteristics". The study continued to discuss how self-drying roof systems will maintain their integrity, reduce building maintenance capital and will have positive environmental benefit from the increased roof enclosure serviceability.

Calculations from the ORNL study indicated that the development of a self-drying roof enclosure shall have a net positive impact on both the economy and society. These calculations demonstrate that increasing the predicted service life from 15 years to 20 years will reduce the current cost of roofing by $21 \%$ or ( $\$ 12$ billion/year). To put this value in perspective, with inflation, the cost of re-roofing in 2017 dollars would be $\$ 22.5$ billion a year. The environmental impact from re-roofing a pre-mature roof enclosure moisture failure is predicted at 0.4 billion $\mathrm{ft}^{3}$ of waste a year. The two previous impact predictions on cost and environment can be calculated 
from existing historic data, however the impact due to wet insulation is unknown. Performance and financial impacts due to wet insulation is commonly unaccounted for as the impact usually goes unnoticed until there is a failure event (i.e. leak or an impact on occupants). Increased heat flow due to wet insulation does have a significant impact on the building owners financial bottom line and noted calculations can assist in predicting the impact on the building owner's energy costs. Appendix A provides the equation, example and solution for a wet mineral wool roof in Toronto, Ontario.

To minimize the impact of moisture reducing the overall performance of the roof enclosure, ORNL reviewed various strategies to transfer moisture out of the enclosure quickly. ORNL indicated that downward drying was the most effective measure for transferring the moisture out of the roof enclosure, therefore the first retrofit design was the "cork" technique. The "cork" technique consisted of drilling holes through the insulating concrete $600 \mathrm{~mm}$ apart, filling the holes with vapour permeable cork and complete by installing a re-cover membrane with new insulation on top of the concrete. A similar approach for drying was designed for roof enclosures utilizing vapour impermeable insulation. Holes were drilled into the moisture compromised insulation; existing roof membrane were repaired to create vapour retarder; and a new recover insulation and membrane were installed. With metal deck being semiimpermeable, holes were drilled below to promote additional drying through convection. Vapour diffusion ports were the final strategy ORNL tried to incorporate on existing wet roof enclosures to promote self-drying. In conjunction with a new roofing membrane and a semivapour permeable recover board a breather vent was installed on top of the system to promote upward drying. The vapour drive was intended to be passive, however active systems using fans to draw dry air though the semi-permeable recover board were also recommended. The three strategies defined for existing roof enclosures did have some reasonable amount of success however, the development of new self-drying roof enclosures was the focus. 


\section{Original ORNL Self-Drying Roof Hygrothermal Models}

Baseline calculations for three conventional built up roof enclosure (BUR) were incorporated into the Rode hygrothermal modelling software. The composition of the three baseline built-up roof enclosures located in Chicago, Miami and Seattle are consist of;
a) Liquid asphalt roof membrane, 2" rigid glass wool and a metal deck with 1 perm
b) Liquid asphalt roof membrane, 2" perlite insulation and a metal deck with 1 perm
c) Liquid asphalt roof membrane, 2" PIR insulation and a metal deck with 1 perm

To simulate a leak in the base line model, water representing $10 \%$ moisture content by volume was added to the top $10 \mathrm{~mm}$ of the thermal insulation. To establish the predicted drying time, the saturated thermal insulation had to return to the original equilibrium moisture content. The chart below demonstrates the predicted baseline roof enclosure drying times in the locations previously identified.

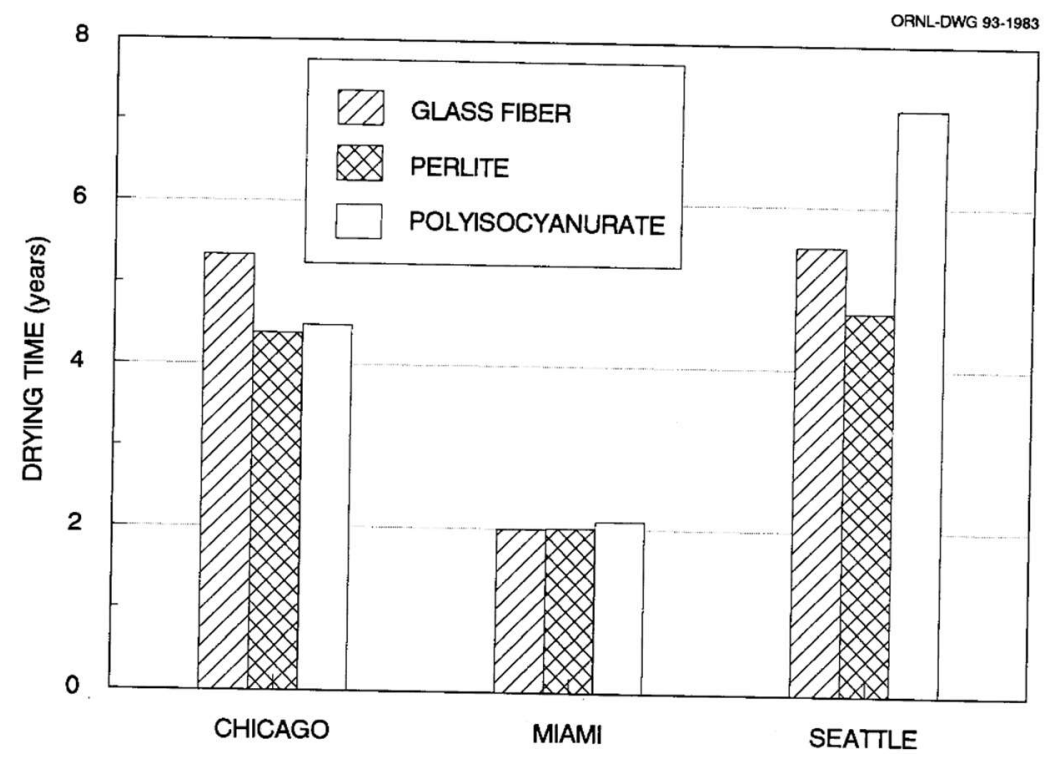

Figure 1 - Actual Drying Time of Original ORNL Self-Drying Roof Enclosure Designs

Results from the Rode Hygrothermal Model identified Miami had the fastest drying time irrelevant of insulation type used with an average drying time of 2 years. The Miami drying time was significantly faster than Chicago and Seattle due to the temperatures and amount of solar 
radiation. Chicago's roof enclosure drying time averaged 4.5 years where as Seattle's roof enclosure drying time averaged 6 years. Even though Chicago has a colder climate, the amount of solar radiation striking the black roof membrane was greater. ORNL identified solar radiation as the largest influence on the potential drying time whereas, the effect of drying due to insulation type was secondary.

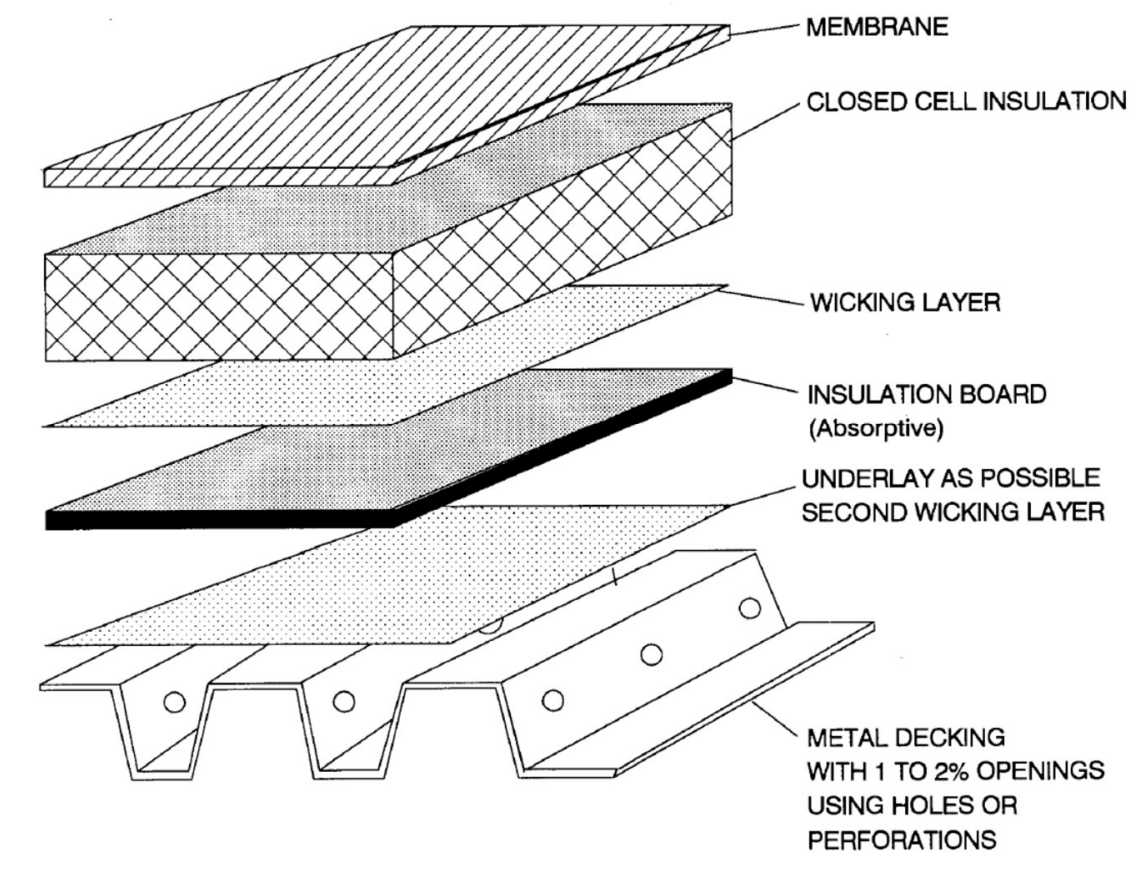

Figure 2 - ORNL Developed Modern Self-Drying Roof Isometric Drawing

The development of the ORNL modern self-drying roof originated predominately from the work conducted by Powell and Robinson (NIST). However, 6 years of research and the completion of 27 roof test specimens assisted ORNL with the understanding of how self-drying roof enclosures are to be constructed. As shown in the figure above the final design of the ORNL self-drying roof enclosure includes (Top to Bottom); vapour impermeable roof membrane, vapour impermeable roof insulation, wicking layer, absorptive insulation board, $2^{\text {nd }}$ layer of wicking membrane and a metal deck with $2 \%$ voids. This theoretical self-drying roof enclosure performance data was imputed into a hygrothermal model with performance conditions and ran over 1,500 times. The 
summary of typical results from the hygrothermal modelling performed by ORNL are identified in Figure 3.

\section{ORNL's Self-Drying Roof Model}

Variables for the self-drying roof remained constant with the baseline variables, however the metal deck in this scenario is perforated ( $2 \%$ voids). The composition of the three self-drying built-up roof enclosures located in Chicago, Miami and Seattle consist of;

d) Liquid asphalt roof membrane, 2" rigid glass wool and a metal deck with perforated deck

e) Liquid asphalt roof membrane, 2" perlite insulation and a metal deck with perforated deck

f) Liquid asphalt roof membrane, 2" PIR insulation and a metal deck with perforated deck

The chart below demonstrates the predicted baseline roof enclosure drying times in the locations previously identified.

Fibrous insulation types (perlite and fiberglass) installed overtop of a perforated metal deck (2\% voids) did show a significant drying potential versus the baseline model. Downward drying through the perforated metal deck was the key to the rapid drying potential of the fibrous insulation type roof enclosures. The PIR insulation roof did show a $50 \%$ reduction in drying time over the base model however, fibrous insulation types out performed the vapour impermeable PIR insulation by 4 to 7 times. Regardless of the climate zone, fibrous insulation types, when used with a perforated metal deck had the greater potential of drying. The strategy of using all vapour permeable components below the roofing membrane in a self-drying roof is promising, but understanding the potential for winter wetting in cold climates is needed. 


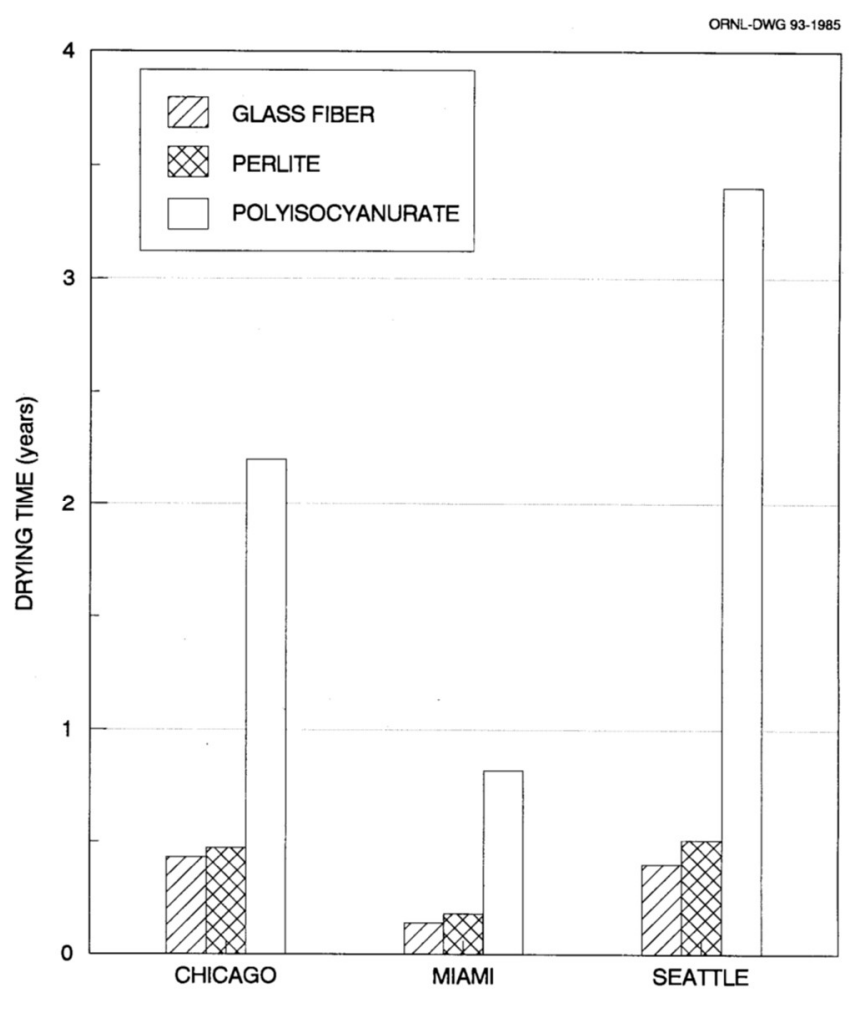

Figure 3 - Predicted Drying Time of Modern (New) ORNL Self-Drying Roof Enclosure Designs

Figure 2 and Figure 3 demonstrate ORNL's modern self-drying roof enclosure. The drying potential of the modern self-drying roof (figure 3) considerably outperforms the drying potential of the ORNL original self-drying roof enclosure (figure 2). The ORNL original roof enclosure's drying potential highly impacted by temperature and solar radiation, whereas the ORNL modern self-drying roof enclosure was highly impacted by insulation type. ORNL modern self-drying roof indicate that glass fiber roof insulation had the fastest drying time, perlite the second fastest and polyisocyanurate had the slowest rate of drying. 


\subsection{METHODOLOGY}

Moisture in building enclosures ultimately reduces the effectiveness, thermal performance and longevity of building enclosures; this is especially valid for flat roof enclosures. The reason roof enclosures are more susceptible to moisture ingress is due to their horizontal orientation and complexity. Generally, there are three modes of moisture ingress in roof enclosures: water leaks, condensation (vapour diffusion and air leakage) and built in construction moisture. With many complex orientations and systems located on the roof, trying to eliminate the water ingress into these roof enclosures is almost impossible. In addition to the construction complexities, moisture ingress can also originate from poor design, roof membrane detailing, material failures etc. Roof moisture issues are always going to be present in the Construction Industry, therefore the design strategy for roof enclosures should permit passive or semi-active drying. The intent of this research is to predict and simulate, using WUFI 6.1 hygrothermal software, for the development of a self-drying roof that follows the ORNL principles for selfdrying in all North American climate zones. The systematic approach for the development of the self-drying roof enclosure is to obtain previous data on self-drying roofs from external sources; research testing of new construction materials and their in-situ performance; and to applied fundamentals of building science and then apply them to hygrothermal simulations (WUFI 6.1).

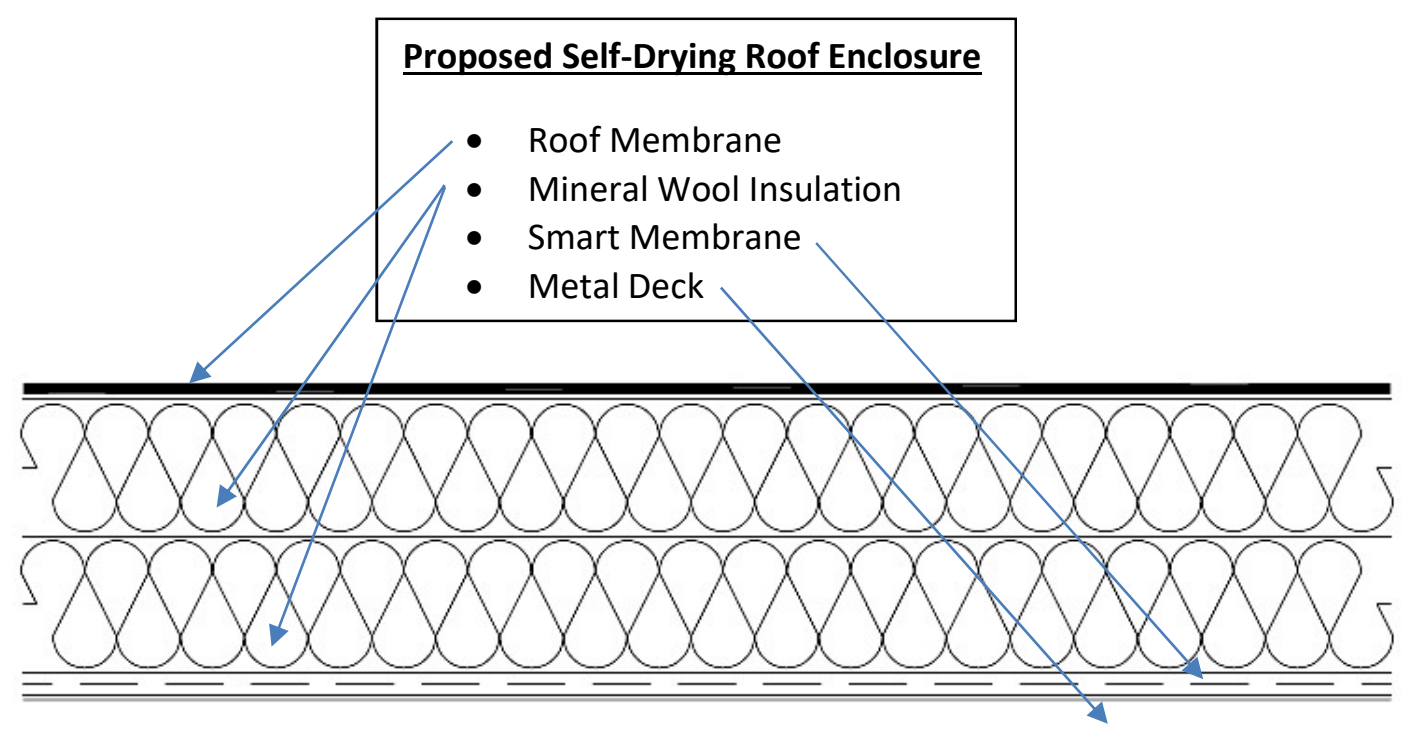

Figure 4-Simulated "Ryerson" Self-Drying Roof Enclosure 
ORNL had the most in-depth information on the development of a realistic self-drying roof design therefore, the ORNL Modern Self-Drying Roof (Figure 2) would be the theoretical baseline model for research and simulation. From the ORNL baseline model, a research program was developed by ROXUL Inc. and RDH to validate an RHD/ROXUL self-drying roof design under realistic conditions. The trial roof enclosure was built utilizing a test hut built in accordance to the ORNL self-drying roof principals and placed on a farm in Waterloo, ON. The RDH/ROXUL roof design consisted of 4 components; roof membrane, ROXUL TopRock roof insulation, CosellaDorken Smart membrane and a metal roof deck (Figure 4). Performance data for this trial "selfdrying" roof enclosure design can be found in the document "Intentional Wetting of Roof Assemblies". The data which will be obtained from the in-situ roof test hut research by RDH will be used to validate the baseline "Ryerson" self-drying roof hygrothermal model. The validated "Ryerson" model will then be used to create the other remaining simulation models ranging in specific Canadian and American climatic zones and roof membrane colours.

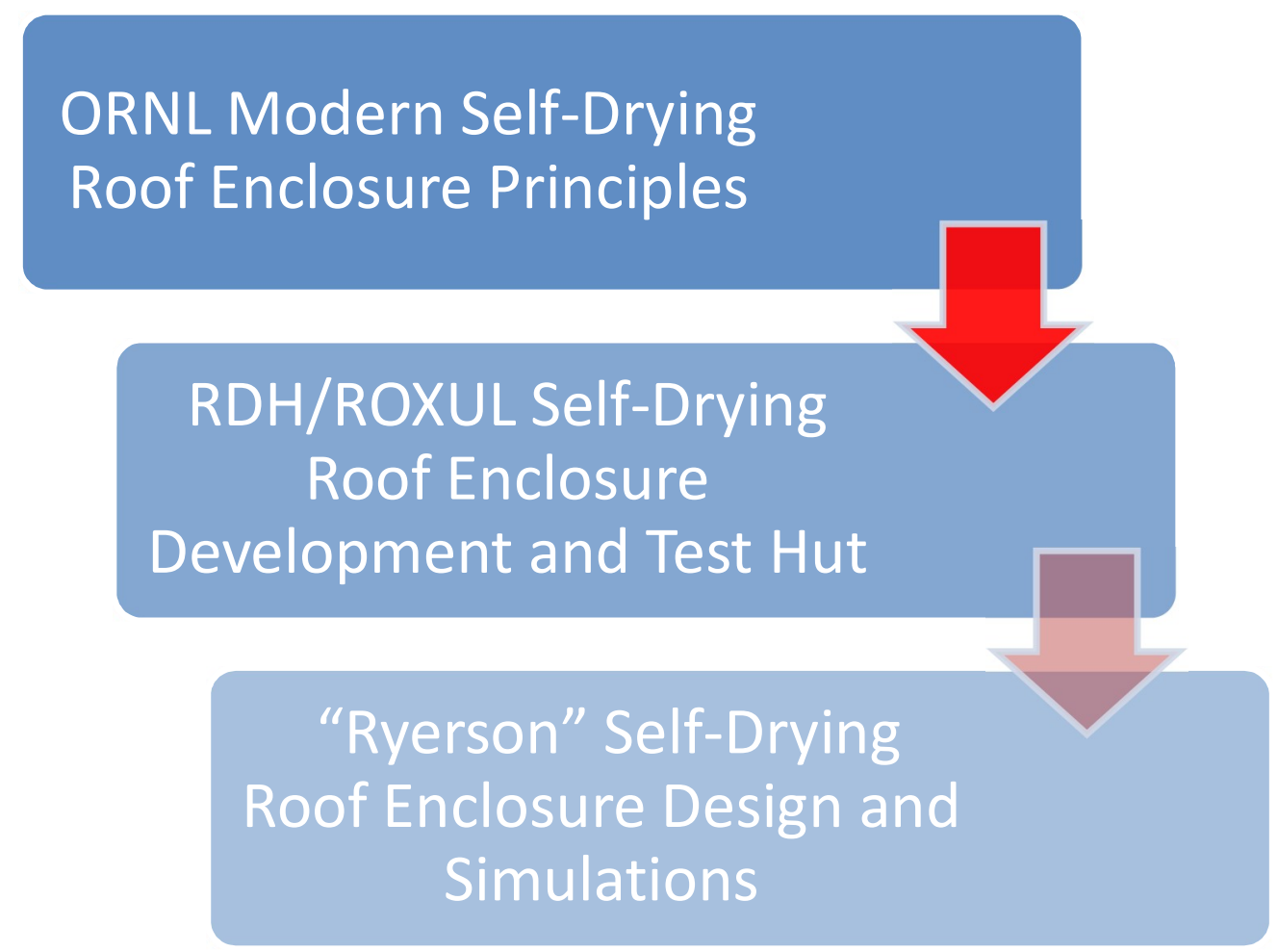

Figure 5 - "Ryerson" Self-Drying Roof Enclosure Development and Simulation 
The following hierarchy diagram demonstrates the methodology thought process for the development of the "Ryerson" self-drying roof enclosure. The initial step in the development of the self-drying roof enclosure was the design concept for the roof enclosure which was based on the ORNL modern self-drying roof. The proposed "Ryerson" design concept was given to a thirdparty building science firm (RDH) to set up, instrument, observe and report. The third-party research on the self-drying roof test hut conducted by RDH and ROXUL was not part of this research, however the data will be used as the "Ryerson” hygrothermal validation tool.

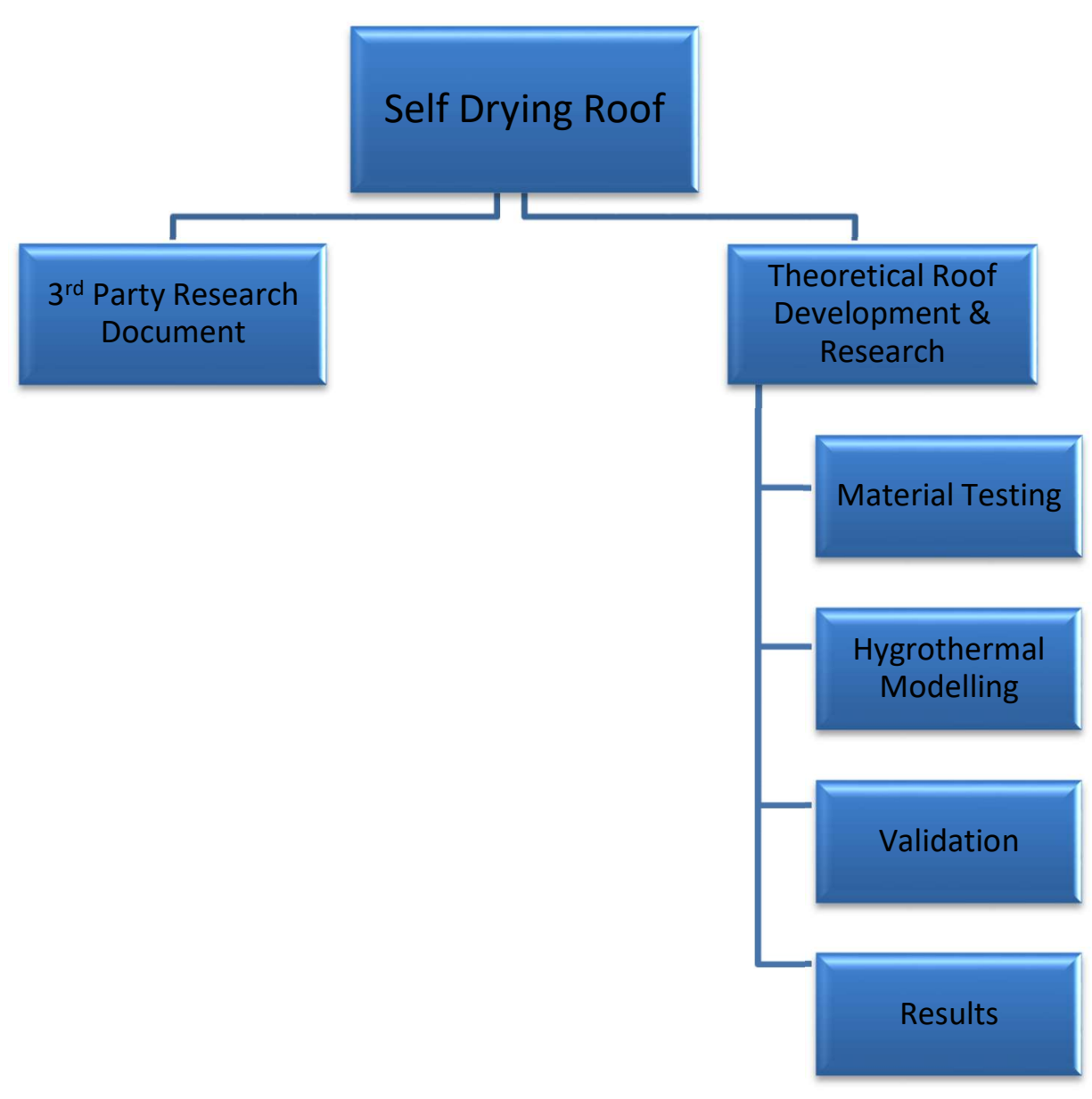

Figure 6 - Hierarchy Diagram MRP Thought/Work Through Process

Material property data needed for the self-drying roof enclosure was not available in WUFI 6.1, therefore relevant material property data testing had to be completed. E96 vapour permeance testing on the Cosell-Dorken varying vapour permeable membrane (smart 
membrane) as well as the metal deck had to be conducted and inputted into WUFI 6.1. Property data testing data is described in the experimental set up section and includes testing on the varying vapour permeable membrane as well as the metal deck. Fraunhofer Institute completed material data testing on ROXUL products in 2015 and incorporated the material property data into the North American material data in WUFI 6.1. To determine if self-drying roof enclosures were effective in all climatic zones, seventy-eight models were completed to assist with the predicted performance of these roof enclosures.

Cosella-Dorken's smart membrane ASTM E96 testing was conducted to understand the vapour permeability performance under a range of relative humidity conditions $(50 \% \mathrm{RH}, 75 \%$ $\mathrm{RH}$ and 90\% RH). To develop the data required for input into WUFI 6.1, ASTM E96 (Standard Test Methods for Water Vapor Transmission of Materials) testing was conducted at RDH laboratories. Three E96 tests with 5 samples each were conducted utilizing the Dry Cup method, Wet Cup Method and the Elevated $\mathrm{RH}$ method. There was a lack of relevant information on the permeance of metal deck therefore, ASTM 96 was also conducted on standard metal decking.) To simulate in-situ 3 metal decking samples with $1 / 4$ " holes were drilled in the metal deck with 2 metal decking samples utilizing end laps and side laps. A brief testing description and testing set up for the various scenarios are described below.

E96 Dry Cup Method - Desiccant is placed at the bottom of the sample dish and sealed with the membrane being tested (i.e. Cosella-Dorken NovaFlexx). Samples were placed in a climate chamber at constant temperature of $25^{\circ} \mathrm{C}$ and a relative humidity of $50 \%+/-2 \%$. These samples were placed in the climate chamber September $19^{\text {th }}$ and finally removed October $18^{\text {th }}$. Samples were briefly taken out weighed and recorded randomly 14 times throughout the date specified. 

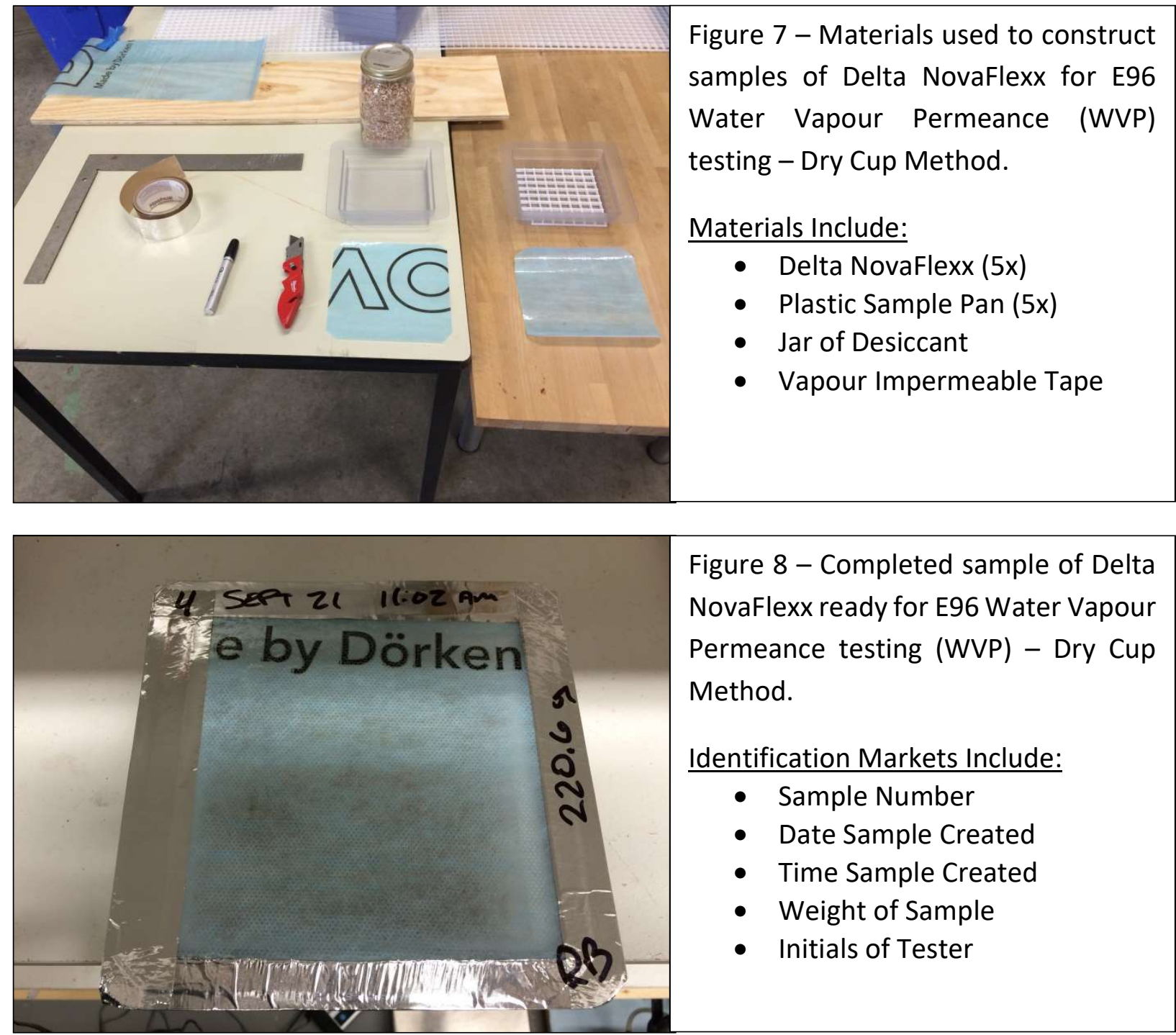

Figure 8 - Completed sample of Delta NovaFlexx ready for E96 Water Vapour Permeance testing (WVP) - Dry Cup Method.

Identification Markets Include:

- Sample Number

- Date Sample Created

- Time Sample Created

- Weight of Sample

- Initials of Tester

ASTM E96 Wet Cup Method - Water is placed at the bottom of the sample dish and sealed with the membrane being tested (i.e. Cosella-Dorken NovaFlexx). Samples were placed in a climate chamber at a constant temperature of $25^{\circ} \mathrm{C}$ and a relative humidity of $50 \%+/-2 \%$. These samples were placed in the climate chamber September $21^{\text {th }}$ and finally removed October $18^{\text {th }}$. Samples were briefly taken out, weighed and recorded randomly 14 times throughout the date specified. 


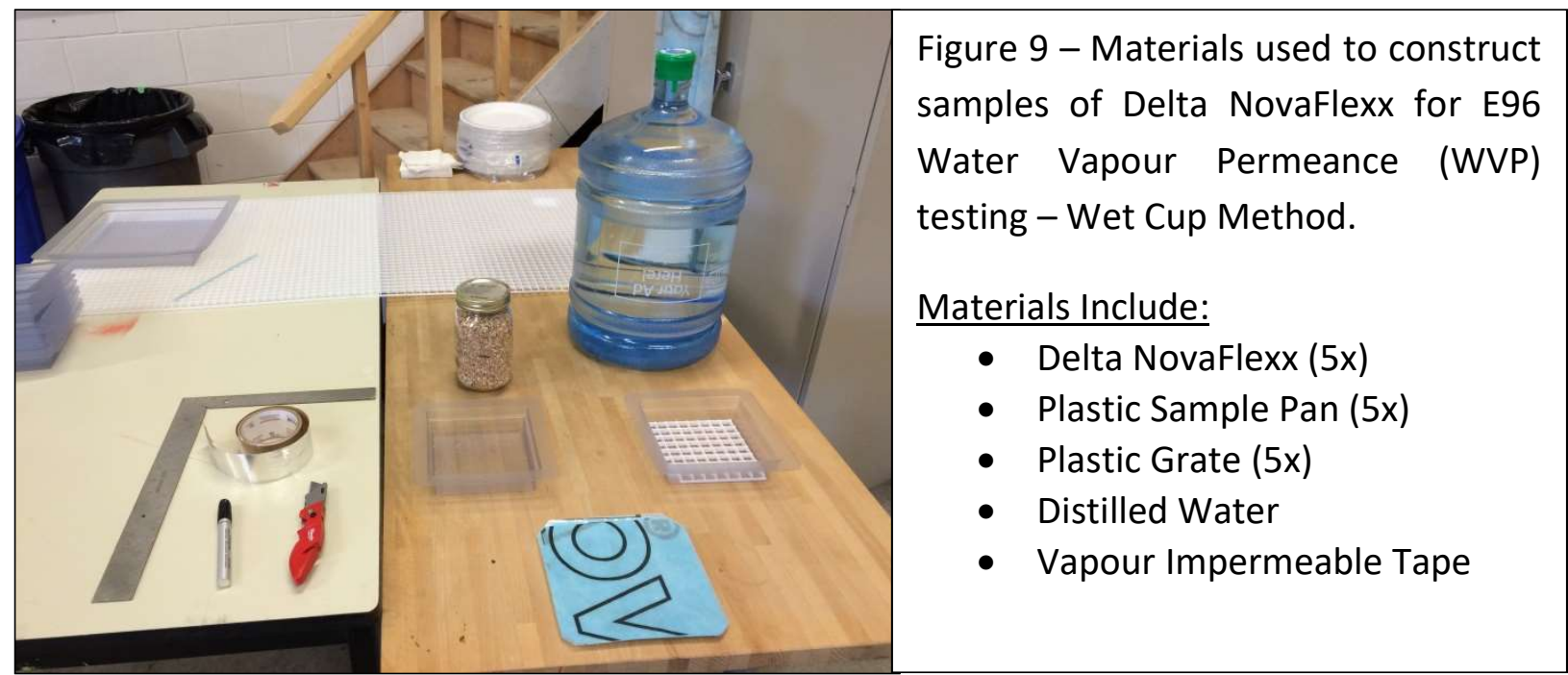

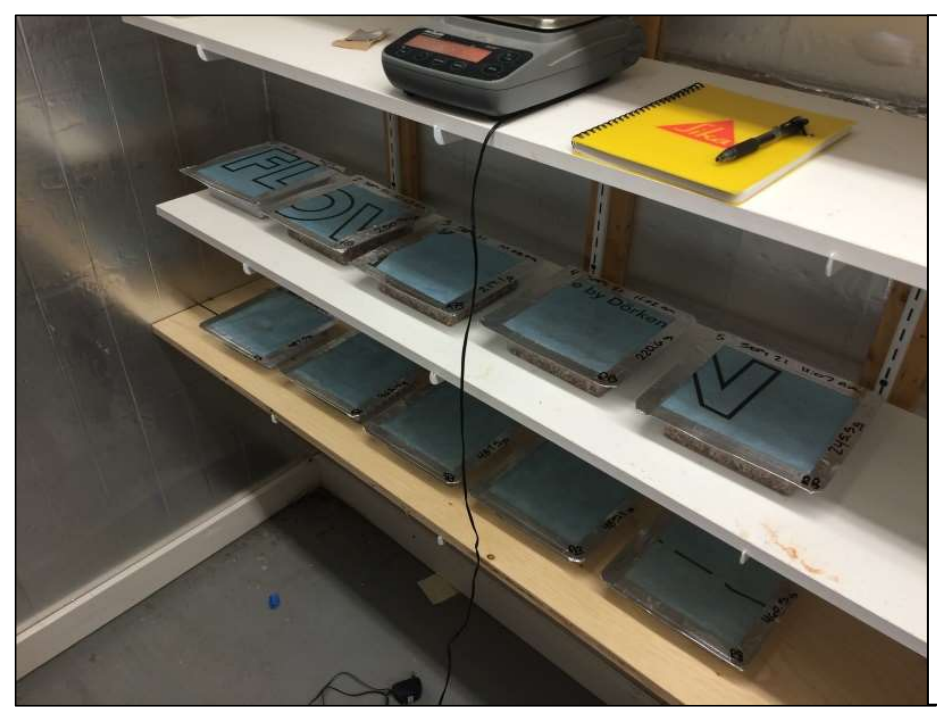

Figure 10 - Dry cup and wet cup samples placed in a climate chamber at $25^{\circ} \mathrm{C}$ and $50 \% \mathrm{RH}$.

Weighing of the samples was typically occurred every one or two days, however no more than 4 days apart.

A calibrated weight scale was used to measure the weight gain (dry cup) and weight loss (wet cup).

ASTM E96 Wet Cup Method High RH - Water is placed at the bottom of the sample dish and sealed with the membrane being tested (i.e. Cosella-Dorken NovaFlexx). Samples were placed in a climate chamber at constant temperature of $25^{\circ} \mathrm{C}$ and a relative humidity of $80 \%+/-2 \%$. These samples were placed in the climate chamber October $1^{\text {st }}$ and finally removed October $14^{\text {th }}$. Metal deck samples were taken out of climate chamber where it was weighed and recorded randomly 9 times throughout the dates specified. 


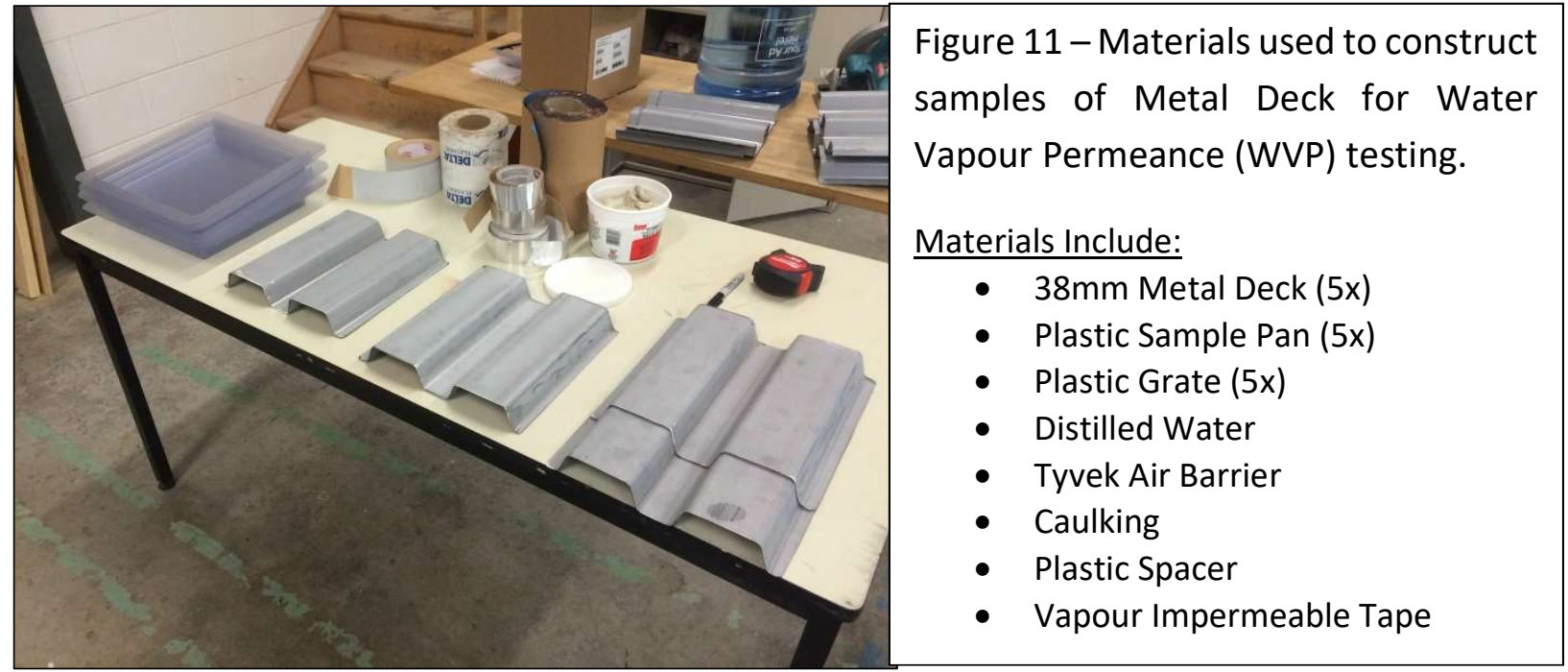

E96 Wet Cup Method - Water is placed at the bottom of the sample dish and sealed with the metal deck. Samples were placed in a climate chamber at constant temperature of $25^{\circ} \mathrm{C}$ and a relative humidity of $50 \%+/-2 \%$. These samples were placed in the climate chamber October $17^{\text {th }}$ and finally removed November $14^{\text {th }}$. Samples were briefly taken out weighed and recorded randomly 18 times throughout the date specified.

Data obtained from the ASTM E96 testing was analysed and inputted into the User Defined data library in WUFI 6.1. See the appendix for the smart membrane and metal deck E96 results.

Hygrothermal modeling using WUFI 6.1 has been a standard industry dynamic simulation tool used to assist designers in the prediction of building enclosure performance over a set period of time. Since seventy-eight models had to be modeled and analysed, the recommended solution for reliability and ease was to utilize WUFI 6.1. Material data that was not available in the material database were tested and uploaded into the user-defined material property library. The self-drying roof enclosure design parameters were inputted into the software program and remained consistent in all other iteration models except for the location, thickness ( $R$ value), metal deck ventilation and colour of membrane. Thickness ( $R$ value) changed in the various models to meet the local energy code requirements. ASHRAE 90.1-2013 was used as the baseline for local $\mathrm{R}$ value requirements. Models for both passive ventilation (none) and active ventilation (5 ACH) were modeled with three roof membrane colours, a black roof membrane, grey roof 
membrane and white roof membrane. The results were recorded based on how many hours the roof enclosure took to dry to equilibrium.

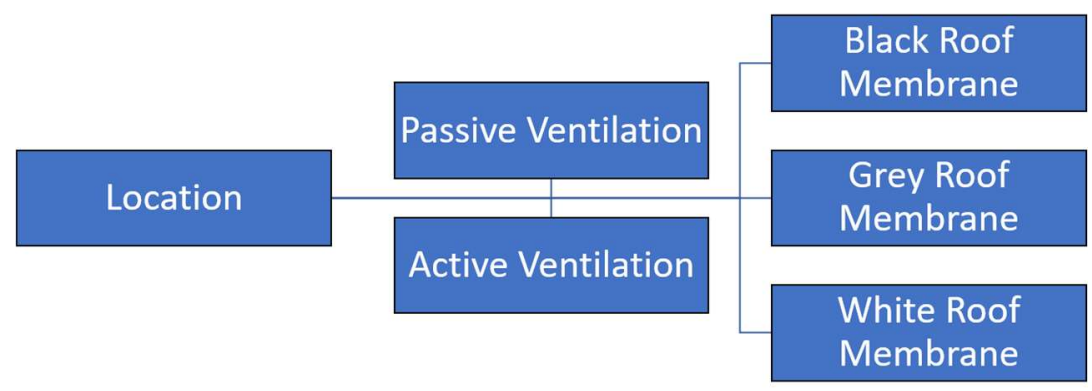

Figure 12 - WUFI 6.1 Testing Matrix for Active and Passive Ventilation

The WUFI 6.1 testing matrix consisted of 13 major North American Cities as described in Table 2, passive and active ventilation ( $\mathrm{ACH}$ through flutes of metal deck) and 3 roof membrane colours (Black, Grey and White). In total, there were 78 WUFI 6.1 iterations encompassing the 3 variables shown above.
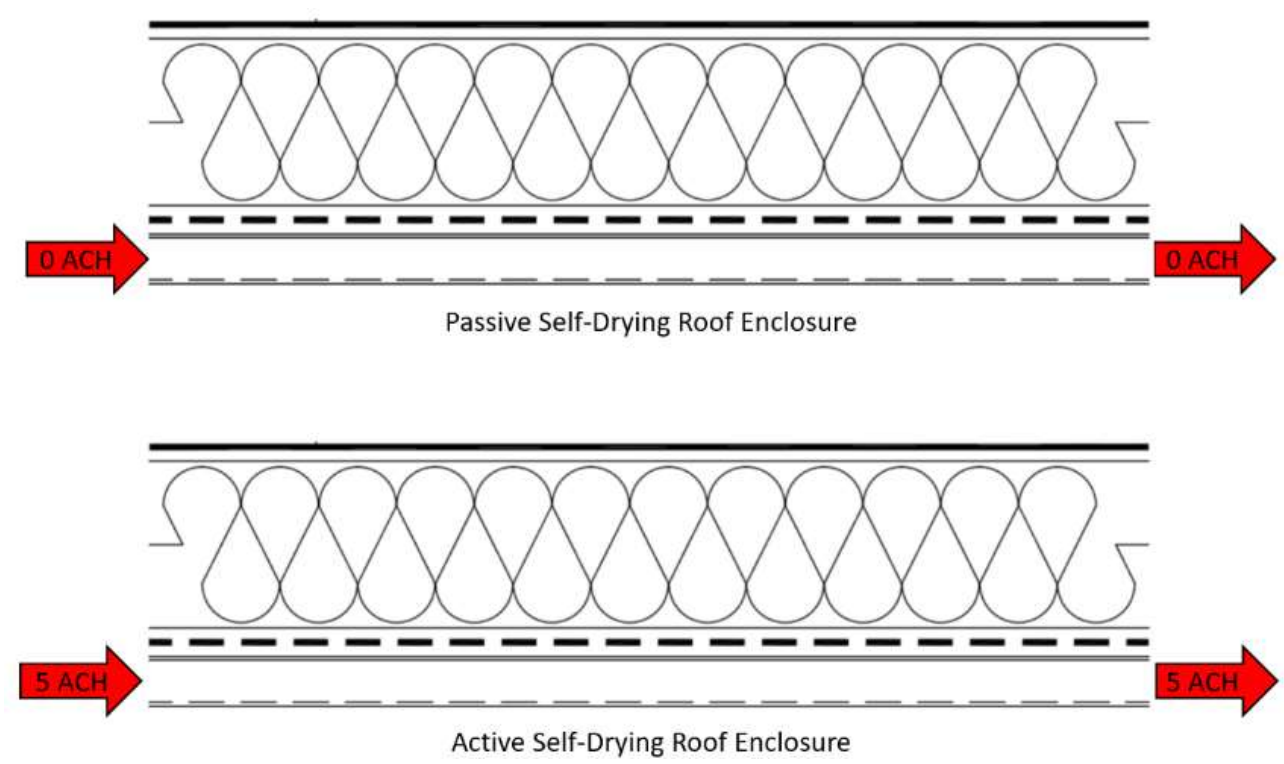

Figure 13 - Passive vs. Active Ventilation Between Metal Deck Flutes 
To determine whether the self-drying roof enclosure design was functional in all climate locations, both Canadian and American cities were selected. The cities selected ranged from hot and humid climates to cold and dry climates. Solar radiation had the largest contribution on the speed of drying however, simply because the roof design was in a warmer climate does not mean that the roof enclosure had a higher potential for drying than a colder climate. The mean cloud index (amount of cloud cover) also had a significant impact on the overall potential for roof enclosure drying. The higher the cloud index the less solar radiation acting on the roof enclosure membrane. Figure 4 indicates the city locations, ASHRAE Zones and roof $R$ value requirements which were used in WUFI 6.1 to evaluate the performance across North America.

\begin{tabular}{|l|c|c|}
\hline \multicolumn{2}{|c|}{ HYGROTHERMAL MODEL LOCATIONS - CANADIAN } \\
\hline \multicolumn{1}{|c|}{ Location } & ASHRAE Zone & Roof R Value \\
\hline St. John's, NFLD & 5 & 30 \\
\hline Vancouver, BC & 5 & 30 \\
\hline Montreal, QC & 6 & 30 \\
\hline Toronto, ON & 6 & 30 \\
\hline Edmonton, AB & 7 & 35 \\
\hline \multicolumn{1}{|c|}{ HYGROTHERMAL MODEL LOCATIONS - USA } \\
\hline \multicolumn{1}{|c|}{ Location } & ASHRAE Zone & Roof R Value \\
\hline Miami, FL & 1 & 20 \\
\hline Houston, TX & 2 & 25 \\
\hline Los Angeles, CA & 3 & 25 \\
\hline New York, NY & 4 & 30 \\
\hline Chicago, IL & 5 & 30 \\
\hline Boise, ID & 6 & 30 \\
\hline Fargo, ND & 7 & 35 \\
\hline Fairbanks, AK & 8 & 35 \\
\hline
\end{tabular}

Table 1 - North American Cities with Roof R Value Requirements (ASHRAE 90.12013 )

Before completing the 78 hygrothermal models of the self-drying roof in the various climatic locations, a validation model was created and compared to the RDH test hut data. The RDH test hut was a research program initiated with ROXUL to determine the validity of a selfdrying roof enclosure in a cold climate. The test hut assembly consisted of a 2-ply mod-bit roof, 2 layers of 3" ROXUL TopRock, Cosella-Dorken smart membrane and a metal deck. Moisture was 
added to the enclosure and the drying potential was monitored. The created validation model design closely resembled the RHD research study roof enclosure design as well as the climatic and moisture inputs. RDH established the quantity of water intentionally leaked into the test hut roof enclosure to simulate a small leak. This quantity of water injected between the two layers of mineral wool insulation was $750 \mathrm{ml}$. The same amount was used in the hygrothermal model, however the leak simulated was between the roof membrane and the top layer of mineral wool insulation. The validation WUFI 6.1 model had an acceptable alignment and trend with the RDH test hut data. Description of the validation process and results can be found in the WUFI 6.1 simulation and validation section. The validated model was the baseline for the remaining 77 hygrothermal models. Description of hygrothermal inputs and parameters are identified in the WUFI 6.1 simulation and validation section.

Two criteria were established to determine whether the modeled self-drying roof enclosures were effective in their climate zone. These two criteria were founded on the six guiding principals for the development of a self-drying roof enclosure identified by ORNL. The two ORNL derived criteria for the determination of the self-drying roof are indicated below.

Criteria $1^{*}$ - Winter moisture uptake during the heating season should not gain more moisture as to increase the mineral wool insulation's effective thermal conductivity to an unacceptable level. An unacceptable level can be identified by using the established $1 \%$ moisture content by volume, multiplied by the $80 \%$ Thermal Resistance Ratio (TRR). A self-drying roof enclosure is considered functional when the winter moisture uptake is below $0.8 \%$ by volume.

* Criteria 1 was established by combining two industry documents (New Wetting Curves for Common Roof Insulations and Thermal Resistance of a Wet Mineral Fiber) into one pass fail criteria. Though this determining factor of acceptable moisture content for a wet roof is not an industry recognized standard or criteria on performance, there have been cases where it was used in the field to determine whether a wet roof should be replaced. 
Criteria 2 - Mineral wool insulation must return to its pre-leak levels (equilibrium) in an efficient amount of time. An efficient time frame would be the average drying time of the modeled ORNL roof assemblies located in Miami, Chicago and Seattle. The average drying time for these locations was 4 months (2880 hours). Therefore, any proposed self-drying roof assembly that surpasses the 2880-hour requirement will not be considered a self drying roof. Note that the 2880-hour requirement is for roof assemblies that have a leak smaller than $750 \mathrm{ml}$.

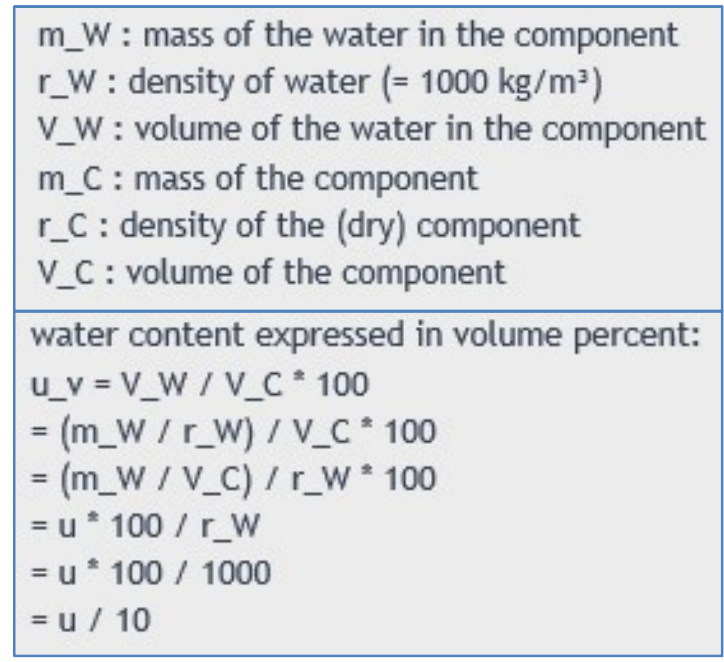

Figure 14 - WUFI 6.1 Calculation Including Key to Calculate Volume Percentage

With the Pass/Fail criteria established, the WUFI 6.1 data from the 78 modeled scenarios can be analysed for their functionality of a self-drying roof enclosure. Mineral wool's moisture content outputs were exported out of WUFI 6.1 in ASCII format; imported and graphed in EXCEL. Figure 7 demonstrates the WUFI 6.1 volume calculation from $\mathrm{kg} / \mathrm{m}^{3}$. If the volume moisture content in the mineral wool due to winter wetting was greater than $0.8 \%$ the proposed self-drying roof was considered non-effective. Moisture content graphs for the 78 self-drying roof enclosures are in the appendix. The number of hours to reach equilibrium after the $750-\mathrm{ml}$ intended wetting (April $1^{\text {st }}$ ) was calculated and completed in EXCEL on the 78 self-drying roof models. If the proposed self-drying roof enclosure dried within 2880 hours after the wetting, the roof enclosure was considered self drying. A list of the drying hours as well as the applicability of the roof design in each climate zone are identified in the results section. 


\subsection{EXPERIMENTAL SET UP}

Many roofing failures are noticed when water leaks directly into the occupied space of a building however, many leaks are never discovered since the water does not actually leak into the occupied space. Nevertheless, damage to the roofing enclosure will occur whether the building owners are aware of the leaks or not. Roofing enclosure repairs due to damage will directly impact the building owner financially as there will be a physical monetary exchange for service. Moisture in roof enclosures have a negative impact on the operating performance of a roof enclosure since the thermal conductivity of the thermal insulation will increase according to moisture content. A reduced enclosure performance will result in unaccounted heat loss, typically unknowingly by the building owner. With reduced thermal performance, the impact will be on the building owner financially and the environment in terms of increased $\mathrm{CO}^{2}$. Minimizing the impact of wet roofs has been studied in the past which has led to new roofing materials becoming available with the potential to make the self-drying roof more efficient.

The objective of this research is to predict and simulate a self-drying roof enclosure design which allows moisture to quickly migrate to the interior (dry) and be assembled economically locally throughout North America. The purpose of using darker membranes is to absorb the solar radiation from the sun and use the energy to transfer the moisture to the interior conditioned space. Efficient moisture transfer to the occupied space shall be accomplished by utilizing highly vapour permeable materials to allow vapour to transfer unrestricted. ROXUL's TopRock mineral wool roofing insulation was chosen as it would be an effective way to meet local energy codes as well as to allow for quick moisture movement. In 2009 ROXUL's TopRock roofing insulation was re-introduced to the market with an R value of 3.9 per inch and a vapour permeance of 30 US perms. To deal with moisture drives in both directions, the Cosella-Dorken NovaFlexx would be an excellent choice as the vapour permeance of the material changes with $\mathrm{RH}$ levels. Locating the smart membrane on the metal deck below the insulation would allow for drying downward if water entered the enclosure in addition to retarding the vapour drive into the enclosure. For moisture to be effectively transferred downward to the interior the metal deck should have a higher level of permeability. The deck could be perforated to allow for drying inward or have 
some amount of cross ventilation through the flutes of the metal deck to direct the vapour saturated air out.

Climatic locations would have a significant impact on the amount of solar radiation hitting the surface of the roof membrane, therefore determining their drying times. The relationship between roofing membrane colour and amount of short wave radiation absorptivity would also vary dependent on the location of the roof enclosure. An educated guess would believe that the best performing self-drying roof enclosure would be a black membrane roof in Miami and the worst performing self-drying roof enclosure would be a white roof in Fairbanks. Estimates could be made to determine if a self-drying roof is applicable in all cities using available tools that can accurately predict the drying potential.

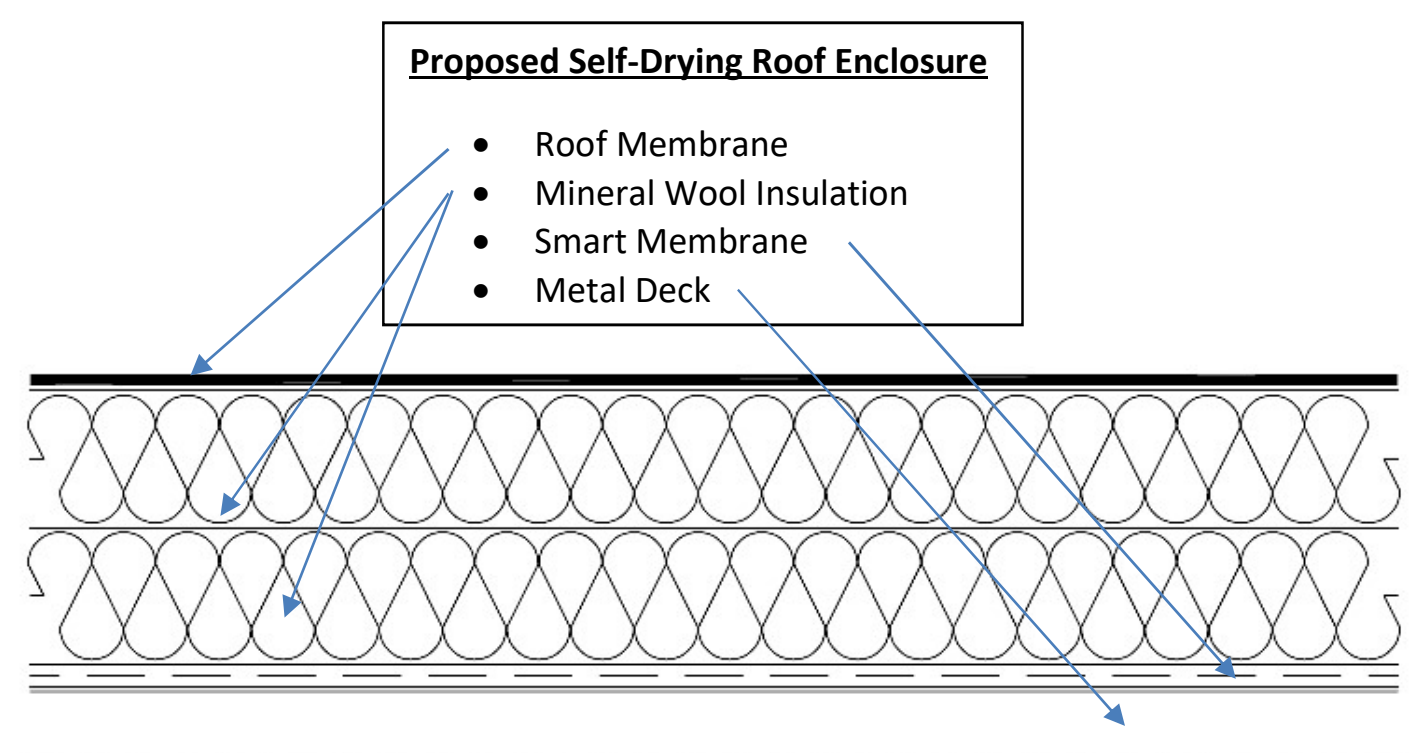

Figure 15 - Section Through Proposed and Modeled Self-Drying Roof Enclosure

There are dynamic variables that can change how the self-drying roof design will function in operating conditions. A few that come to mind include the amount of water, thickness of insulation, outdoor/indoor temperatures, shading, other colour membranes, added materials in design etc. With the concept still in its infancy, a satisfactory approach would be to start with 
some basic parameters and determine if the theory of a self-drying roof enclosure is plausible. Advanced research, testing and design should continue if the results look promising.

To predict if the proposed self drying roof enclosure design was suitable for applicability in all North American climates simulations would have to be replicated and compared to the ORNL 6 characteristics for self-drying roof enclosures. The proposed self-drying roof design will be inputted into WUFI 6.1 with both realistic conditions and climates chosen. The self-drying roof assembly design will remain constant, except for the insulation thickness. The thickness will be determined based on the ASHRAE 90.1 2013 R value requirements. Input parameters will remain stationary, except for two conditions. The first condition is climate, representative city in each of the 8 climate zones in the USA will used as well as a representative city in each of the 4 climate zones in Canada will be used. Black, grey and white membranes will be modeled in each climate zone to predict each drying time of the proposed self-drying roof enclosure. Data obtained from these simulations will be recorded and compared to the ORNL requirements. The predicted results will be identified as performs (no concerns), warning (caution) and warning (not recommended). 


\subsection{WUFI 6.1 SIMULATION AND VALIDATION}

WUFI 6.1 is a hygrothermal software that predicts transient "realistic" 1-D calculations of heat and moisture transport in building enclosures that are exposed to various climatic conditions. WUFI 6.1 was developed by the Department of Hygrothermics at the Fraunhofer Institute in Germany and utilizes state of the art hygrothermal analysis coupled with validated outdoor testing and laboratory data. Generic and proprietary material property data are used to assist in calculating the moisture storage and liquid transport functions of common construction materials. Climatic data such as outdoor temperatures, driving rain and solar radiation are used to simulate enclosure performance under dynamic climatic conditions. This section will cover the WUFI 6.1 model set up as well as the parameters chosen for the development of the proposed self-drying roof enclosure.

As previously mentioned, WUFI 6.1 is user friendly program but a solid understanding of building science is required to ensure accurate results and analysis. There are three segments in WUFI 6.1: Component, Control and Climate. Each segment has modifiable sub segments that the user can alter to suit the specific design and climatic conditions. A brief introduction and applicable model inputs used in the proposed design of the self-drying roof enclosure are demonstrated below.

The materials used for the proposed self-drying roof enclosure in WUFI 6.1 were proprietary when available and generic when no other specific material data was available. The roofing membrane used in this model was Roof Membrane V13 and is considered an extremely vapour closed membrane at less than 0.003 US perms. Fraunhofer Institute conducted laboratory testing on the ROXUL TopRock in 2015 and the material property data in the database is considered accurate and reliable. Material property data for the Cosella-Dorken NovaFlex and Metal Deck were tested in RDH laboratory according to ASTM E96. Results from the ASTM E96 were incorporated into WUFI 6.1 user defined data base. The air space used between the underside of the smart membrane and top surface of the flute deck was $40 \mathrm{~mm}$ without added moisture.

Using verification data and validation data for the development and understanding of a credible and accurate simulation model is the goal for any designer wanting to use computer simulation. WUFI 6.1 does not imitate real world scenarios however data obtained from these models can assist the stakeholders in making informed decisions. Developing a WUFI 6.1 model 
with realistic conditions and realistic information is the most effective way designers can predict enclosure performance. The self-drying roof enclosure model development was based on the ROXUL/RDH study "Intentional Wetting of Roof Assemblies". This study was a year long research project initiated by ROXUL to develop and effect self-drying roof enclosure though downward drying and/or through vapour diffusion vents. The RDH report is in the appendix section of this report.

$\mathbf{0 \Delta}$ Weather Station

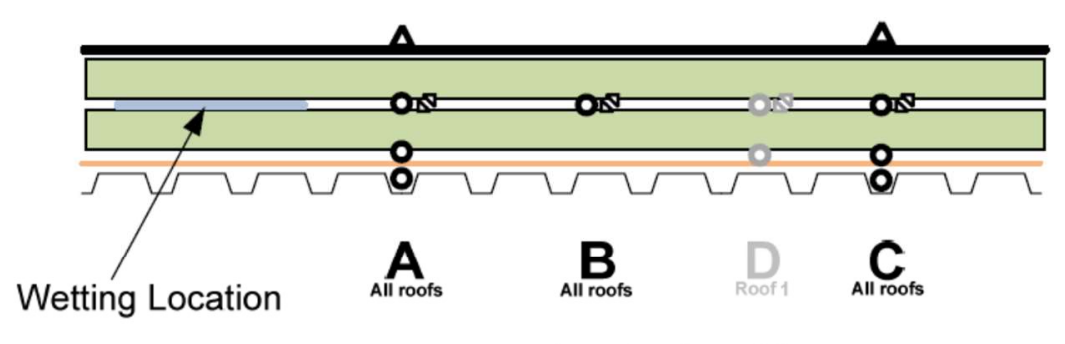

OA Interior Conditions

- Relative Humidity and Temperature Sensor Package

$\Delta$ Temperature Sensor

$\Delta$ Moisture Content Wafer and Temperature Sensor Package

Figure 16 - RDH/ROXUL Self-Drying Roof Design Showing Sensor Locations

Schematic section above describes the self-drying roof enclosure that was built within a $\mathrm{RDH}$ test hut and delivered to a farm site in Waterloo, Ontario. The composition of the roof includes 2 ply modified bitumen roof membrane, two layers of 3" TopRock Insulation, CosellaDorken NovaFlexx smart membrane and a metal deck with holes drilled in deck to simulate screw holes. The interior conditions were like standard interior conditions of $22^{\circ} \mathrm{C}+/-3^{\circ} \mathrm{C}$ and $30 \% \mathrm{RH}$ +/- 5\%. Relative Humidity and Temperature sensors were installed at locations A, B and C as indicated in the schematic above. Moisture Sensors were also installed in these locations and were in place to indicate the estimated roof enclosure drying time. The wetting location is shown between the two layers of insulation and there was a scheduled injection of $750 \mathrm{ml}$ of water two times a day for two days. The 750-ml intentional wetting occurring between the two mineral 
wool insulation boards occurred June $6^{\text {th }}, 2016$ and completed June $10^{\text {th }}$ 2016. The preliminary $\mathrm{RDH} /$ ROXUL 8-month wetting/drying research results were analysed and delivered to ROXUL for review. Data obtained from the RDH/ROXUL test hut study between June $6^{\text {th }}$ and July $12^{\text {th }}$ will be used to validate the baseline "Ryerson" self-drying roof enclosure simulation.

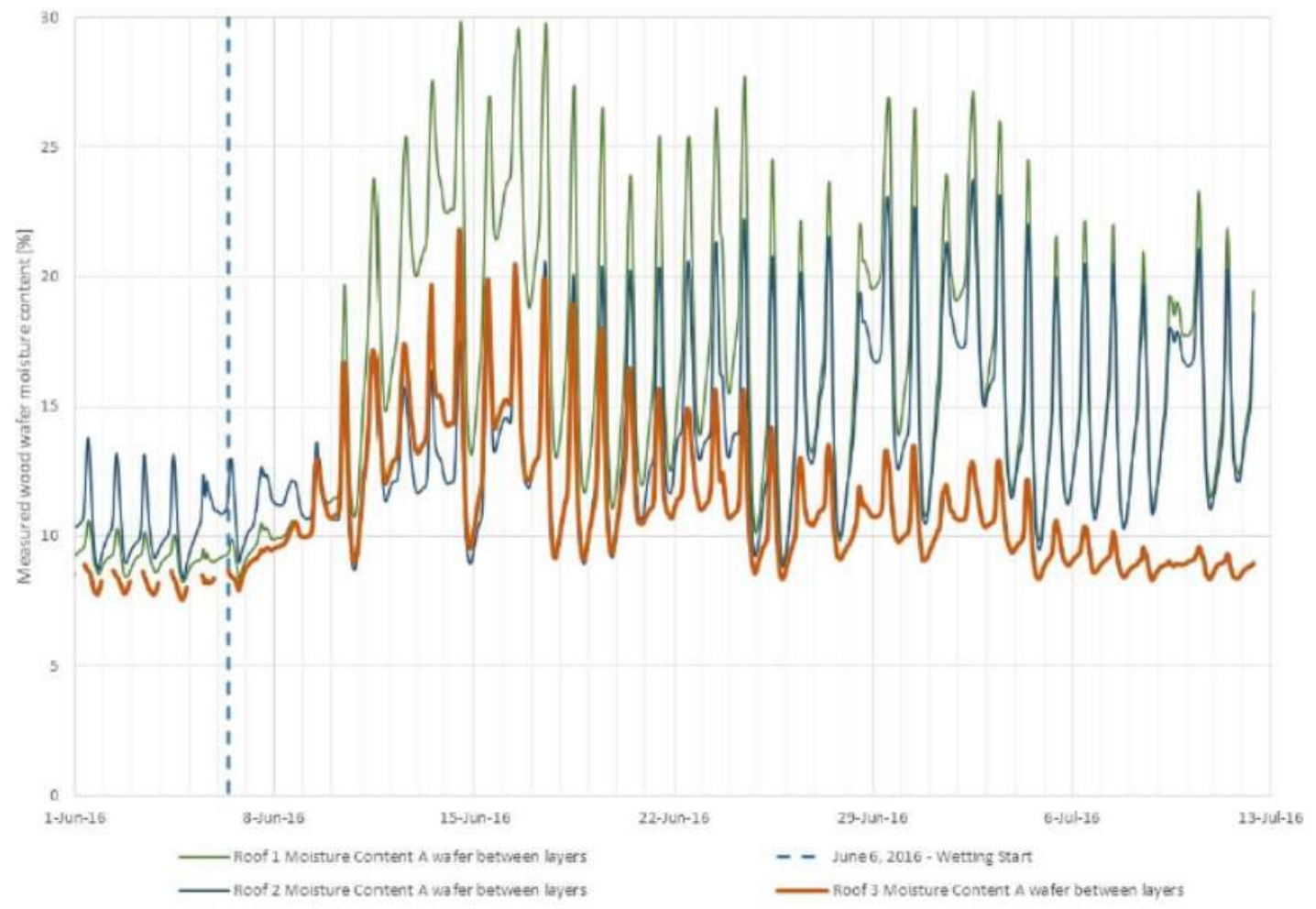

Figure $17-$ RDH/ROXUL Test Hut Roof Drying profile between June $1^{\text {st }}$ and July $13^{\text {th }}, 2016$

The graph above identifies 3 roof construction profiles with their respective wetting and drying profiles. For the purpose of this study only roof 3 (orange line) will be discussed. Roof 3 represents the RDH/ROXUL self drying roof design (roof membrane, mineral wool insulation, smart membrane and metal deck). The moisture content on the $y$ axis represents the moisture content in the wood wafer at location $A$ as shown on figure 18 and the $x$ axis represents the time frame of the roof enclosure wetting and drying time line. Between June $1^{\text {st }}$ and June $6^{\text {th }}$ there was no water injected into the roof enclosure, however there does appear to be some moisture transport within the assembly. The daily moisture transport within the assembly is due to the temperature fluctuations between the ambient interior and exterior conditions. This 
phenomenon is common in roofing application especially when the insulation medium is highly vapour permeable. The equilibrium moisture content for the wood wafer is around $9 \%$, however the deviations between the night and day conditions is small (+/- 2\%). With the introduction of moisture representing a leak on June $6^{\text {th }}$, there is a drastic increased moisture content with the peak of $22 \%$ on June $14^{\text {th }}, 2016$. There is an obvious sign of roof enclosure drying during the June and July months, with the roof assembly achieving equilibrium on July $11^{\text {th }}, 2016$. From the roof assembly wetting on June $6^{\text {th }}, 2016$ to the roof assembly "dry" equilibrium on July $11^{\text {th }}, 2016$, the number of hours to achieve drying is approximately 816 hours.

To develop working hygrothermal WUFI 6.1 models to predict the performance of selfdrying roof enclosures throughout North America a validation model was created. The "Ryerson" WUFI 6.1 validation model roof components were identical to the RDH/ROXUL test hut roof, which includes a roof membrane, 2 layers of 3" TopRock insulation, a modified Cosella-Dorken smart membrane and modified metal deck. Both the Cosella-Dorken and metal deck material profiles were modified in the WUFI 6.1 material database to represent the E96 laboratory testing. Toronto "cold year" was the WUFI 6.1 climatic weather file used for the validation, even though the test hut was in Waterloo, ON. Since Waterloo, ON was within $100 \mathrm{~km}$ of Toronto, ON there was an assumption that the influence from different local climates on the drying profile was negligible. The test hut interior conditions were set within the WUFI 6.1 validation model in attempt to achieve similar temperature and $\mathrm{RH}$ profiles. The other input parameters set in the WUFI 6.1 validation model are identified between Figure 13 and Figure 18. The location of 750$\mathrm{ml}$ of water injection were different for both the RDH/ROXUL roof assembly and the "Ryerson" roof assembly. The RHD/ROXUL test hut had the water injection between the two boards, where as the water injection for the validation simulation was between the roof membrane and the top surface of the mineral wool insulation. The frequency and time of water injection however was identical between the RDH research project and the WUFI 6.1 hygrothermal simulation. The WUFI 6.1 simulation period resembled the time profile for the RDH/ROXUL roof assembly. The theoretical wetting and drying profile for the upper layer and lower layer of TopRock insulation is described on figure 19. 
To validate the "Ryerson" hygrothermal WUFI 6.1 model with the RDH/ROXUL test hut data, the wetting and drying profiles were plotted on the same axis of scale and compared to each other. It must be pointed out that the wetting and drying profile for the RDH/ROXUL roof assembly was based on a wood wafer placed 12" away from the wetting surface where as the "Ryerson" simulation was determined using the moisture content of the upper layer and lower layer of mineral wool insulation. With the wood wafer and mineral wool insulation water absorption and moisture content characteristics being so different, an assumption was used to determine the wetting and drying correlation. The correlation assumed that when water was introduced and absorbed the moisture content trend was upward and when there was drying the moisture content had a downward trend. The final validation objective was to determine the number of hours it took the wood wafer to dry out vs. the mineral wool insulation to dry out after the intentional and scheduled water leak. The wetting and drying profiles for the RDH/ROXUL roof assembly and the "Ryerson" roof assembly are shown on figure 19.

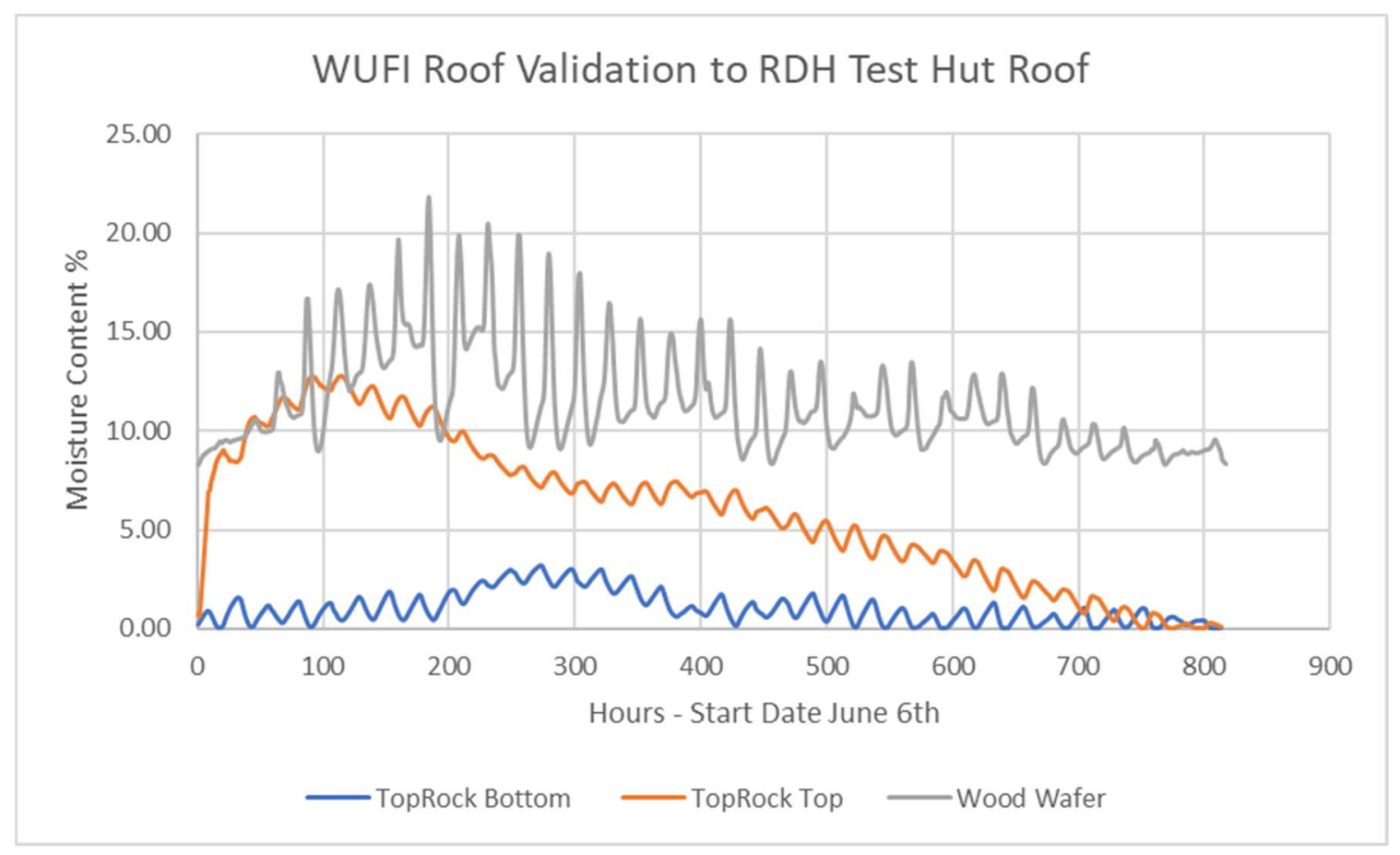

Figure 18 - Test Hut vs. WUFI 6.1 Validation Wetting and Drying Profiles 
Figure 23 identifies the Moisture Content in both the Wood wafer (Green Line) in the RHD/ROXUL test hut and the Top Layer and Lower Layers of TopRock mineral wool insulation (Red and Blue Line). Wetting of the materials occurred at the 0 hour and ceased approximately at the $120^{\text {th }}$ hour (2 $75-\mathrm{ml}$ wetting a day for 5 days). Wood wafer and mineral wool insulation all increased in moisture content during the initial few hours of wetting. The wood wafer had a maximum moisture content of $22 \%$ at 190 hours, mineral wool top layer has a maximum moisture content of $13 \%$ at 90 hours and the lower layer had a maximum moisture content of $2.5 \%$ at 260 hours. After the initial wetting, the assemblies demonstrated drying in each assembly with their drying to equilibrium occurring around the same point in time. The RDH/ROXUL assembly reached drying equilibrium around 816 hours whereas the "Ryerson" self-drying roof assembly reached drying equilibrium around 812 hours. With both roof assemblies meeting "dry" equilibrium around the same period, 812 hours vs. 816 hours, there is an assumption that the two roof assemblies had the same rate of drying under similar conditions. The WUFI 6.1 simulation is assumed to be validated with the RDH/ROXUL test hut based on the information provided and simulated. The "Ryerson" validated simulation was the base model for all other hygrothermal models, except for variables such as roof membrane colour, climate zone and insulation thickness. 


\subsection{RESULTS AND DISCUSSION}

Prior to the WUFI 6.1 modeling to determine if self-drying roof enclosures were effective in the various climate zones in North America, ASTM E96 testing had to be completed to determine realistic inputs for the model. Four rounds of ASTM E96 testing had to be completed under specific conditions to determine the materials dynamic performance. The Cosella-Dorken NovaFlexx membrane was tested to the Dry Cup method, the Wet Cup method and the High RH method. Five samples for each ASTM E96 test method was conducted at the RDH laboratories. Cosella-Dorken NovaFlexx tested to the Dry Cup method achieved an average permeance of 0.79 US perms. The Wet Cup method for the smart membrane achieved an average permeance of 8.0 US perms and the RH method achieved an average of 9.45 US perms. Calculations, weights and times of measurements for the smart membranes are in the appendix. ASTM E96 Wet Cup method was used to determine the predicted permeance of the metal deck in-situ. Three samples of the metal deck were constructed with two $1 / 4$ " holes drilled into the flutes to represent fastener penetrations. One sample representing a side lap joint and one sample representing a butt end joint was tested in parallel with the three other samples. The average vapour permeance according to ASTM E96 on the metal deck samples tested was 1.0 US perms. Calculations, weights and times of measurements for the metal deck is in the appendix.

Seventy-eight hygrothermal models were created in 13 various climate zones across North America utilizing two ventilation paths and three various membrane colours. The models simulated run time period was 8760 hours with a start date of October 1 . Criteria 2 indicates that any self-drying roof enclosure that has a drying period longer than 2880 hours is considered non-effective. The following charts demonstrate the drying hours for both the Canadian and American cities with passive ventilation (no ventilation) and active ventilation ( $5 \mathrm{ACH}$ ) for black, grey and white roof membranes. 
Table 1 - Predicted Drying Hours for Canadian and American Passive Self-Drying Roof Enclosure

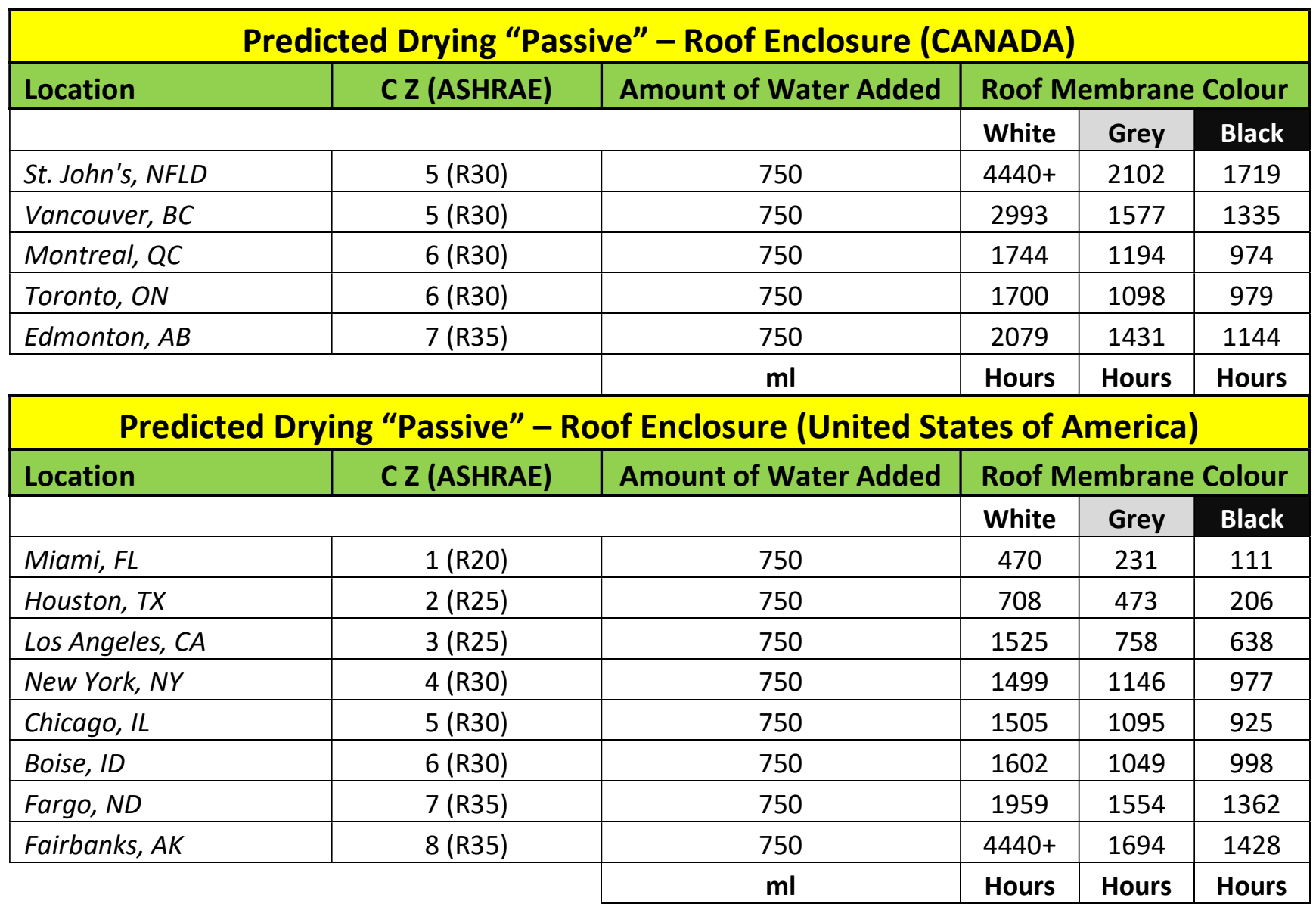

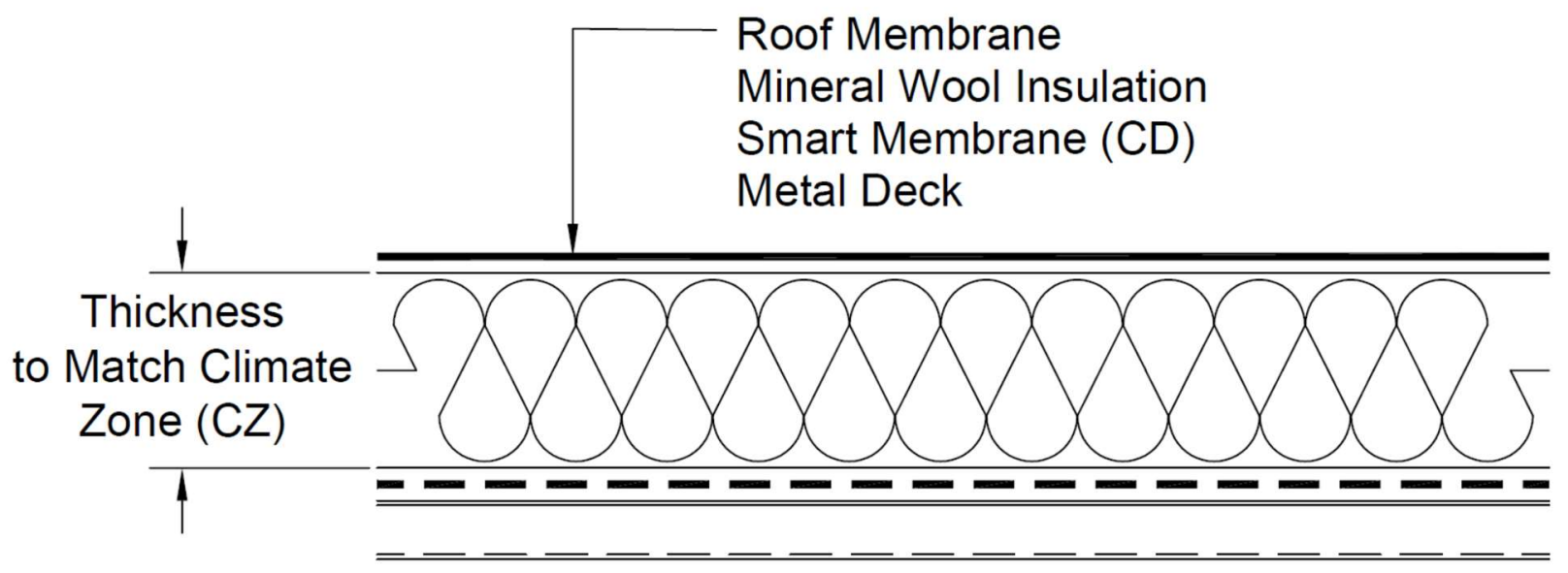

Figure 19 - Section Through "Ryerson" Proposed Self Drying Roof 
Table 2 - Predicted Drying Hours for Canadian and American Active Self-Drying Roof Enclosure

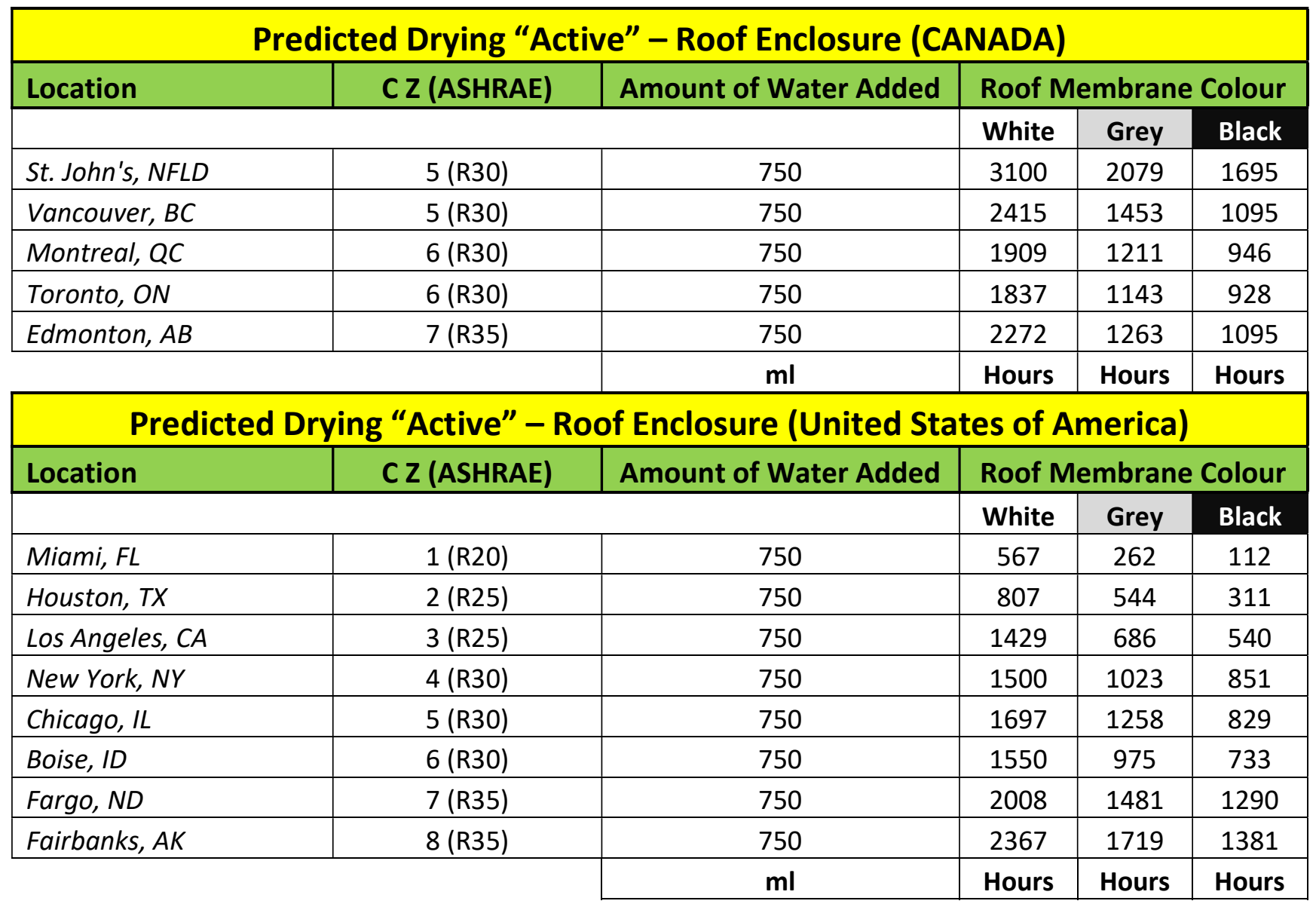

The requirements for Criteria 1 state that any moisture uptake by the TopRock insulation during the heating season more than $0.8 \%$ by volume will not be considered a self-drying roof enclosure. Applying Criteria 1 and Criteria 2 to the results of the 78 WUFI 6.1 models determined which self-drying roof enclosures were considered functional. The following chart lists the seventy-eight proposed self-drying roof enclosures and their functionality status. Green indicates self-drying roof enclosure with no predicted concerns; yellow represents self-drying roof enclosure with potential concerns; and red indicates a non-functioning self-drying roof enclosure. 
Table 3 - Self-Drying Roof Enclosure - Climatic Zone Location Functionality

\begin{tabular}{|c|c|c|c|c|c|c|}
\hline \multicolumn{7}{|c|}{ "Ryerson" Self-Drying Roof Enclosure - Location Functionality } \\
\hline Location & Passive & $\mathrm{OACH}$ & & Active & $5 \mathrm{ACH}$ & \\
\hline \multirow[b]{2}{*}{ CANADA } & Black & Grey & White & Black & Grey & White \\
\hline & & & & & & \\
\hline \multicolumn{7}{|l|}{ St. John's, NFLD } \\
\hline \multicolumn{7}{|l|}{ Vancouver, BC } \\
\hline \multicolumn{7}{|l|}{ Montreal, QC } \\
\hline \multicolumn{7}{|l|}{ Toronto, ON } \\
\hline \multicolumn{7}{|l|}{ Edmonton, ALB } \\
\hline \multicolumn{7}{|l|}{ UNITED STATES OF AMERICA } \\
\hline \multicolumn{7}{|l|}{ Miami, FL } \\
\hline \multicolumn{7}{|l|}{ Houston, TX } \\
\hline \multicolumn{7}{|l|}{ Los Angeles, CA } \\
\hline \multicolumn{7}{|l|}{ Ney York, NY } \\
\hline \multicolumn{7}{|l|}{ Chicago, IL } \\
\hline \multicolumn{7}{|l|}{ Boise, ID } \\
\hline \multicolumn{7}{|l|}{ Fargo, ND } \\
\hline \multicolumn{7}{|l|}{ Fairbanks, AK } \\
\hline Legend & $<2300 \mathrm{~h}$ & Performs & $>2300 \mathrm{~h}$ & Caution & $2880 \mathrm{~h}$ & Warning \\
\hline
\end{tabular}

To effectively achieve a self-drying roof enclosure, ORNL identified 6 required characteristics of a roof enclosure under operating conditions. It is important to understand that these 6 required characteristics were developed many years ago utilizing typical roofing materials of the time. New roofing material technologies have been developed since ORNL's original study, therefore the 6 required characteristics can be slightly modified. The 6 ORNL required characteristics are described in detail below and incorporate the relation to the proposed selfdrying roof enclosure modeled performance.

1) Decreasing moisture content - if the roof enclosures moisture content continuously increases due to the interior conditions and in conjunction with climatic conditions, a self drying is not feasible. 
Traditionally roof enclosures located in Northern climates of Canada and the United States (cold climates) have limited or no possibility of drying due to the use of extremely low vapour permeable materials (i.e. roof membrane and vapour barriers). Assembly drying would not be required if the roofing assembly was built without construction moisture and $100 \%$ airtight and watertight. Achieving a perfect roof enclosure is almost impossible due to the complexities in construction. Improperly manufactured materials, improperly installed materials and neglect are traditionally the most common factors leading to the premature deterioration of roofing enclosures. Building roof enclosures with a double vapour retarder can have the potential to cause significant durability and performance issues in the roof enclosure. To minimize the risk of low performing and less resilient roof enclosures a new system needs to be developed. Eliminating a vapour impermeable membrane below the insulation and allowing for inward drying is a possible solution to maintain performance and resilience.

Designing self-drying roof enclosures in warm/hot climates has the potential to be more effective and efficient due to the constant higher outdoor temperatures. Vapour impermeable membranes are generally not used in the warmer/hot climates therefore, the higher outdoor temperatures can drive the moisture to the inside which will promote drying. Allow for significantly prolonged heat transfer from the outside to the inside which will assist drying to the inside. The lack of membrane below the roof insulation can assist with the enclosure drying, however the lack of a membrane can also introduce unwanted moisture from air leakage. A membrane should always be used below the insulation to minimize the impact of moisture laden air entering the enclosure.

The following two graphs demonstrate the decreasing moisture content characteristics of the $3^{\text {rd }}$ party test hut self-drying roof as well as the decreasing moisture content in the validation model. Moisture is "ping-ponging" up and down in moisture content due to the difference between the day and night temperatures. With mineral wool being vapour permeable the moisture has the potential to move to the colder locations unrestricted. 


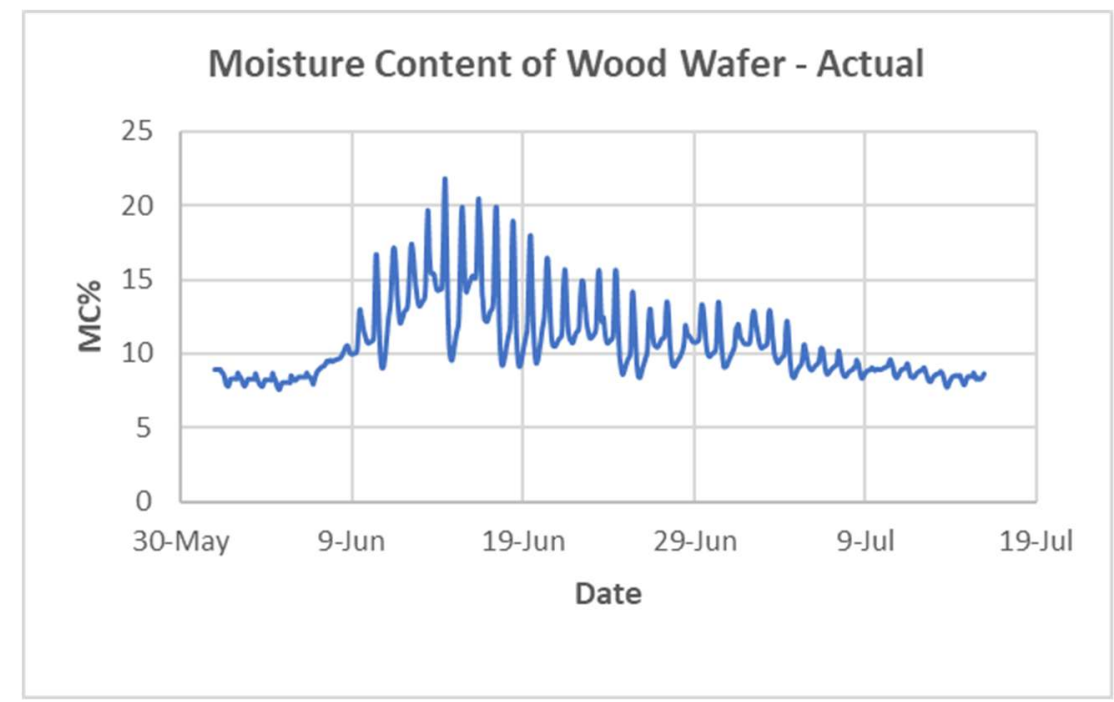

Figure 20 - Actual Moisture Content in Wood Wafer (RDH Test Hut)

$\mathrm{RDH} / \mathrm{ROXUL}$ test hut data of wood wafer moisture content pre-and post-wetting. Minor fluctuations of moisture content due to temperature cycling occur between June $1^{\text {st }}$ and June $6^{\text {th }}$. $750 \mathrm{ml}$ of intentional water added between roof boards June $6^{\text {th }}$ to simulate roof leak. Moisture content increases in wood wafer due to introduction of water (22\%), however dries to the inside due to heating from the exterior, vapour permeable insulation and a varying permeable vapour retarder membrane. Moisture content in wood wafer reached equilibrium (9\%) after 39 days of drying.

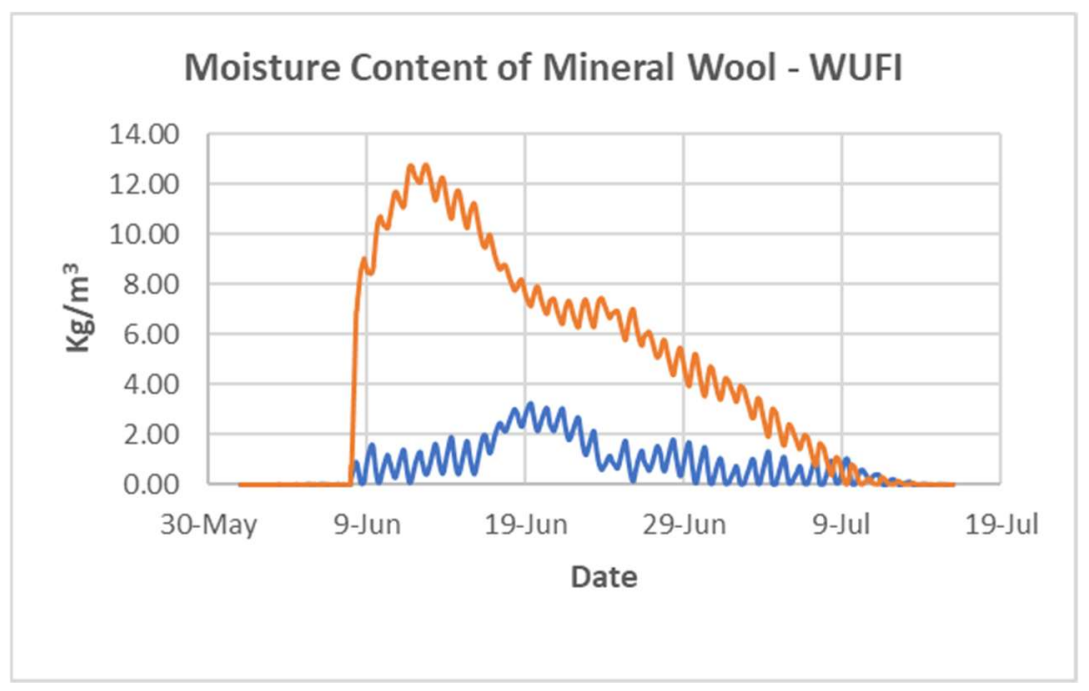

Figure 21 - WUFI 6.1 Predicted Moisture Content in Mineral Wool Top and Bottom Layer 
WUFI 6.1 prediction demonstrating the potential drying of Mineral Wool Roofing Insulation pre-and post-wetting. Red line represents the bottom MW board and the blue line represents the top MW board in the roofing enclosure. Prior to the June $6^{\text {th }}$ wetting, the moisture content in the Mineral Wool is minimal, however there is minor amounts of built in moisture that was fluctuating due to the cycling of exterior outdoor temperatures. Moisture content in the bottom MW board spikes from $0.1 \mathrm{~kg} / \mathrm{m}^{3}$ June $6^{\text {th }}$ to $13.0 \mathrm{~kg} / \mathrm{m}^{3}$ on June $13^{\text {th }}$, however dries relatively quickly to equilibrium July $14^{\text {th }}$.

Whether there is built in moisture or moisture from a roof leak, movement occurs when there is a difference in temperature. The moisture typically moves to the cold side at night (roof membrane) and cold side during the day (vapour retarder), depending on the location and season. Even when the water was introduced into the test hut roof enclosure and in the WUFI 6.1 model the overall drying trend is downward. Based on the two charts above and the 78 WUFI 6.1 models the drying trend is always downward therefore satisfying the first condition of a selfdrying roof enclosure identified by ORNL.

2) Moisture uptake due to condensation - if the roof enclosure moisture content (specifically moisture absorbing materials) continuously increases due to condensation, a self drying is not feasible.

ORNL's $2^{\text {nd }}$ requirement for an effective self-drying roof enclosure would not meet the intent of the requirement if there was continuous water uptake due to condensation. Modifying this requirement to allow minimal amounts of moisture to condense within the enclosure is acceptable, depending on the amount of reduction in thermal performance. In the case of mineral wool, the thermal performance of mineral wool will be reduced by $50 \%$ if the thermal insulation absorbs more than $1 \%$ moisture content by volume. There are caveats to this rule of thumb but keeping the insulation below 1\% moisture content (see figure 3 ) is essential for effective thermal performance. It was shown through WUFI 6.1 modeling that climatic conditions, colour of roof membrane and the amount of cloud cover had a significant impact of the amount of condensation occurring in the enclosure. A conclusion can be drawn that these 
three conditions ultimately had an impact on the amount of energy (radiation) hitting the roof surface and dictating the amount of drying. Modifying this requirement will allow moisture to condense in the roofing enclosure therefore durability and resiliency become a factor for acceptability. To ensure longevity and efficiency, using non-moisture sensitive roofing materials in the design of the self-drying enclosure, is recommended.

Mineral Wool insulation has been shown to double in thermal conductivity when there is a moisture content of $1 \%$ (volume). Research by Per Ingvar Sandburg indicates there needs to be a constant influx of water to maintain $1 \% M C$ by volume in mineral wool. When there is no constant influx of moisture, the moisture will move to the cold surface and affect only the first few mm of the mineral wool. Tobiasson from the US Corp of Engineers deemed insulation "wet" when the thermal insulations effectiveness drops below $80 \%$ of the dry $\mathrm{R}$ value. Therefore, mineral wool insulation in a self-drying roof enclosure is considered "wet" when the thermal conductivity is reduced to $0.045 \mathrm{~W} / \mathrm{mK}$. For mineral wool to be an effective self-drying roof enclosure insulation it must not uptake more than $0.8 \% \mathrm{MC}$ by volume through condensation. Wet mineral wool above $0.8 \% \mathrm{MC}$ (volume) will not be detrimental to the durability however the product may become soft and eventually have a negative impact on the durability of the roof membrane. All WUFI 6.1 models did show signs of water uptake over time (see figure 5) but did not exceed the critical $0.8 \% \mathrm{MC}$ by volume. Continued research work is recommended for colder climates with interior conditions that have high relative humidity's.

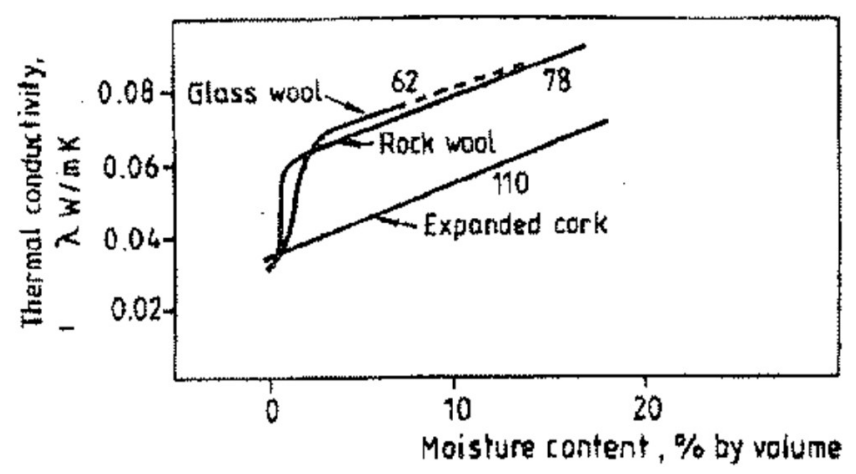

Figure 22 - Thermal Conductivity of Mineral Wool by Percentage of Moisture (Volume) 
Thermal conductivity graph (Figure 22) was obtained from Per Ingvar Sandberg's paper on the "Thermal Resistance of a Wet Mineral Fiber Insulation. Information regarding the 80\% TTR Rule was derived from the US Army Corp of Engineers document "New Wetting Curves for Common Roof Insulations".

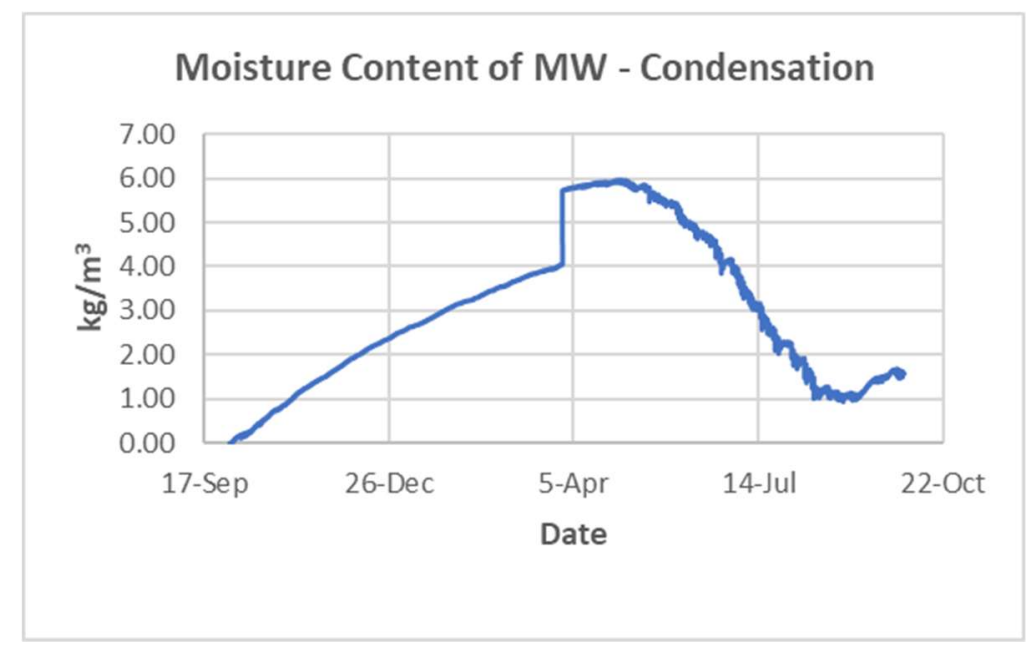

Figure 23 - Predicted Moisture Content Increase in Mineral Wool due to Winter Condensation

Sample of 8760-hour WUFI 6.1 simulation of the "Ryerson" self-drying roof enclosure located in Edmonton modelled with a white roof membrane. The simulation identified substantial water uptake due to winter condensation during the heating months occurring between October and April. Winter condensation occurs due to the interior moisture diffusing though the smart membrane, mineral wool and condensing on the underside of the roofing membrane. $A$ scheduled $750-\mathrm{ml}$ leak occurred April $1^{\text {st }}$ and the actual downward drying began in late April. "Dry" equilibrium in this roof assembly was not achieved until July of the following year. The reason for the long drying period was due to Edmonton's climate and the lack of heat absorbed by the white roof membrane. Though the moisture content in the mineral wool was below the $0.8 \% \mathrm{MC}$ criteria, this system is deemed a failure due to the significant increase in winter condensation.

3) No dripping to interior - if the roof enclosure cannot passively manage bulk water passing into the interior, a self drying roof is not feasible. 
Water leaking into the occupied space is more than just an annoyance to building occupants and/or the building owners. Potential loss of employee time, efficiency, loss of business revenue and impact on the indoor air quality are just a few problems that can arise when moisture enters the occupied space. Using a smart membrane with taped joints below the insulation will minimize the potential of leaked water dripping into the occupied space. The permeance of the smart membrane is higher than a vapour barrier therefore there is a risk of moisture being driven out of the roof enclosure and condensing on the metal deck. To meet ORNL requirements of no dripping to the inside, a hygrothermal study was conducted to verify moisture diffusing out of the enclosure and not condensing on the metal deck. Figure 6 demonstrates the potential for condensation occurring on the metal deck during normal conditions was very low, though the risk becomes higher when a leak occurs and the vapour is diffusing to the inside. Adding active air movement ( $5 \mathrm{ACH}$ ) between the flutes of the metal deck will minimize the potential of condensation. A further study researching higher interior relative humidity and colder interior temperatures will provide additional risk potentials as more extreme conditions.

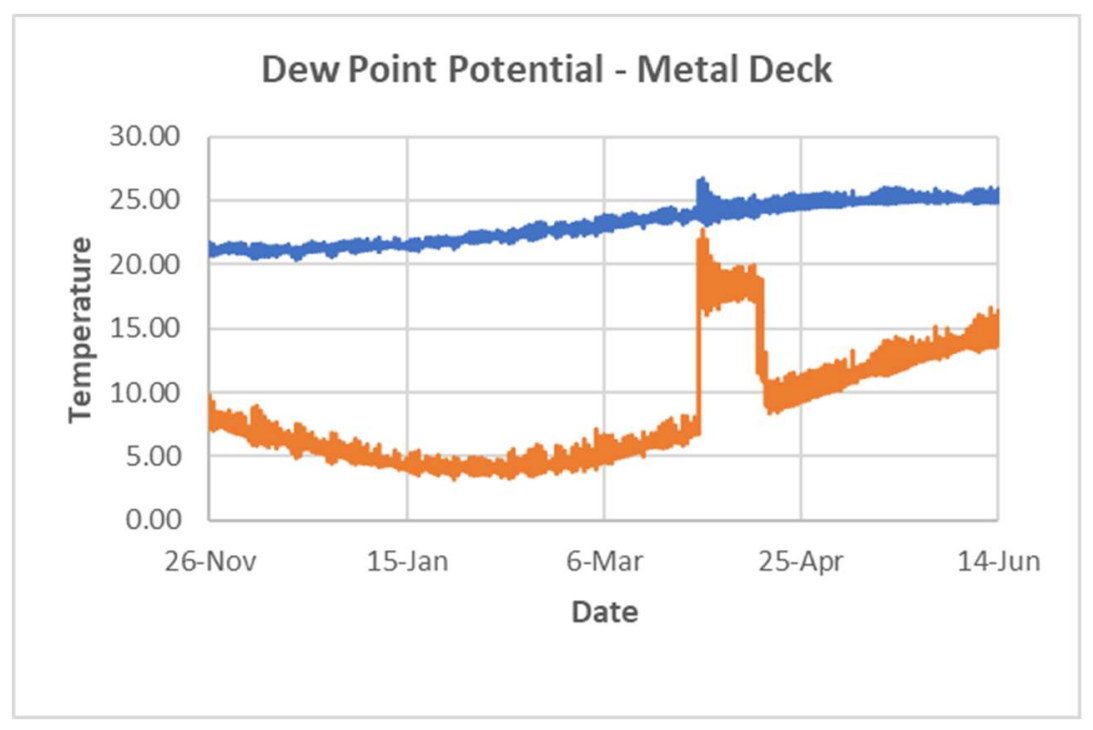

Figure 24 - Predicted Potential Risk of Condensation at Metal Deck During Downward Drying

WUFI 6.1 prediction demonstrating the potential risk of condensation at the metal deck. Blue line represents interior temperature conditions whereas as the red line represents the dew 
point temperature. Risk of condensation pre-wetting and post-drying is very unlikely, however there is a potential risk of condensation at the peak of wetting (April $1^{\text {st }}$ wetting). Condensation risk is only possible if larger amounts of bulk water is present in the roof enclosures.

Under standard operating interior conditions, the risk of condensation at the metal deck is very low. Potential risk in dripping to the interior is elevated when moisture is present in the assembly and diffusing to the interior. The smart membrane also functions as an air barrier restricting the air movement into the roof enclosure. Investigation of all 78 WUFI 6.1 models was initiated to determine if there was an elevated risk of condensation occurring on the metal deck during drying. Based on the investigation findings, this roof design did meet the requirements "no dripping to the interior" performance characteristic.

4) Controlling vapour movement - if the roof enclosure cannot control the vapour movement into the assembly by mode of convection, a self drying roof is not feasible.

Moisture has the potential to enter a roof enclosure by 3 methods: a) bulk water infiltration, b) vapour diffusion and c) moisture laden air (convection). ORNL indicates that a selfdrying roof cannot be achieved if convection of air cannot be controlled. Therefore, strategies on how to maintain moisture control in the roofing enclosure through convection is essential. Key performance criteria are listed below, identifying critical elements which need to be achieved to ensure roof enclosure durability and efficiency.

- Airtightness - Air tightness below the insulation is required to stop/minimize the potential of moisture laden air leaking into the insulation layer where added moisture is likely to accumulate at the underside of the roofing membrane. The smart membrane used below the insulation in a self-drying roof enclosure must be airtight and continuous. Modeling of all self-drying roof enclosure iterations did not include any air leakage past the smart membrane. 
- Ventilation for upward vapour diffusion (wetting) - With air diffusing down into the conditioned space through the smart membrane and into the interior can pose potential condensation risk on the metal deck. Air Convection between the metal deck flutes can minimize the moisture build up in a self-drying roof during the heating seasons. Using 5 $\mathrm{ACH}$ in the metal deck flutes was demonstrated to be an effective method to reduce the impact of humid interior vapour diffusing through the smart membrane to the underside of the roof enclosure. Hygrothermal models were developed using no active ventilation in the metal deck flutes during heating season in Northern Canadian and American climates. In some of the more extreme climates the insulation gained $50 \%$ of the allowable winter wetting due to upward condensation. Hygrothermal models utilizing 5 $\mathrm{ACH}$ in the metal flute decks were more effective in almost eliminating the upward vapour drive into the roof enclosure. Results demonstrating the difference in moisture uptake between the two roof enclosures can be found in the appendix.

- Ventilation for inward vapour diffusion (drying) -The inward vapour drive occurring from the drying of the roof enclosure has two key functions to ensure effective drying. The removal of the moist laden air in the metal decks will reduce the potential for interior condensation on the metal deck. $5 \mathrm{ACH}$ had significant amount of air flow to effectively remove the moist air before it had the potential to condense and potentially leak to the interior. The lack of air movement had an elevated potential risk of condensation on the metal deck. Though the models with no ventilation did not show any signs of condensation on the metal deck, increasing the amount of moisture to dry or reducing the interior temperature may lead to condensation on the metal deck. The second function for adding ventilation is to remove the moist laden air to create a larger moisture transfer gradient. With a larger moisture gradient between the roof enclosure and metal deck the potential for quicker drying can be assumed. $5 \mathrm{ACH}$ ventilation is recommended for the colder climates to minimize the water uptake during the heating seasons, whereas no ventilation is required in the warm/hot climates due to the constantly higher outdoor temperatures. Several strategies for the effective venting of the metal deck can be found in appendix 15. 
5) Controlling water movement - if there is no absorptive layer to displace water and distribute over a wider area, a self drying roof is not feasible.

As previously mentioned, roofing materials utilized in the design of a self-drying roof should be hydrophobic and have the capacity to limit the amount of water take up. The selfdrying roof assembly, designed with mineral wool and a smart membrane, are both vapour permeable and hydrophobic. WUFI 6.1 material data properties for both materials are shown in Figure 7 and Figure 8. Moisture storage function properties in WUFI 6.1 represent how much water is absorbed in the material based on the percentage of ambient relative humidity. The mineral wool has the potential to absorb the leaked water and distribute it over a larger area, however bulk water will move downward due to gravity. With the thermal insulation being vapour permeable, the moisture moves to the cold surface in the form of vapour and then condenses. The "plastic" like smart membranes are thin and do not have the moisture storage or wicking capacity to store water. The leaked water which has been drained from the mineral wool will be collected on the smart membrane and flow to a larger distributed area. Mineral fibre coverboards are used in roof enclosures to separate dimensionally unstable insulation from the roof membrane, create a smooth level surface, increase the walkability on roof etc. To design a quick drying and an economical roof self-drying roof, there was no coverboard included in any of the modelling. Future work can include several types of coverboards and their impact on the drying potential of the roof enclosure. With the materials specified and the hygrothermal modeling completed, the proposed self-drying roof enclosure does meet the intent of ORNL's fifth required performance characteristic for self-drying roof enclosures. 




Figure 25 - Moisture Storage Function for ROXUL's TopRock product listed in WUFI 6.1 North American data base.

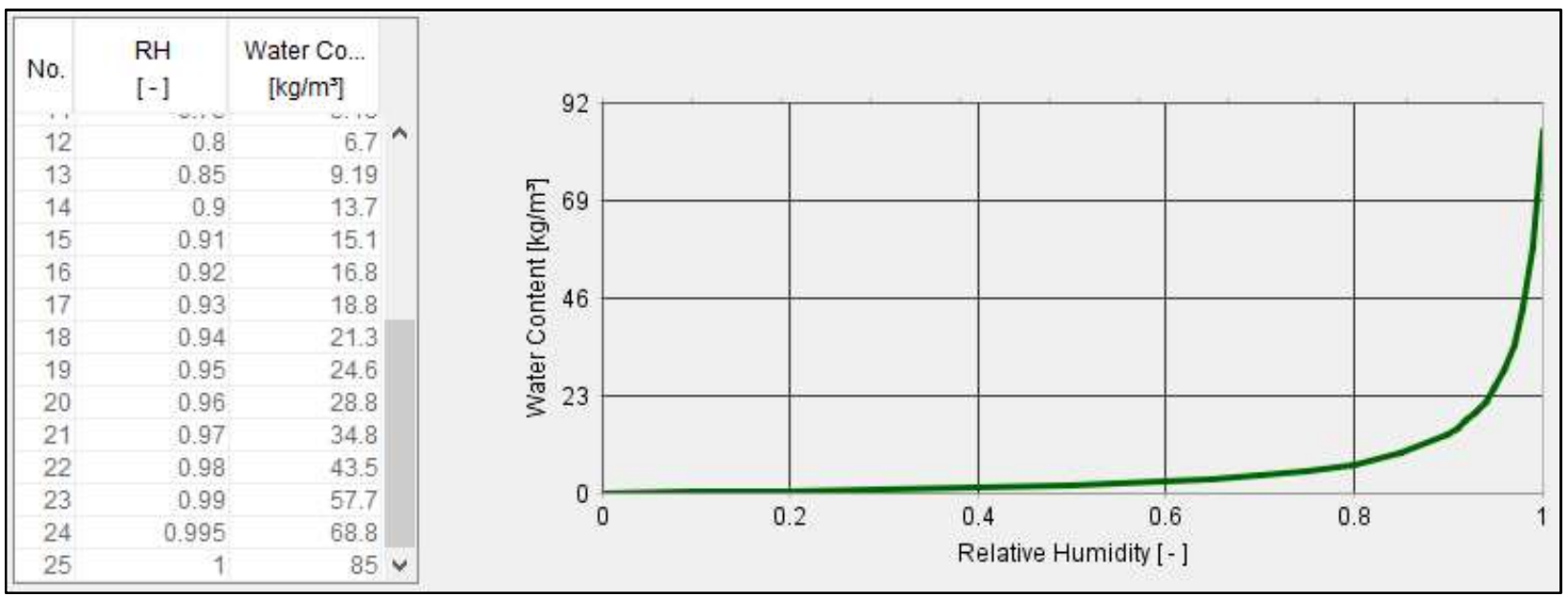

Figure 26 - Moisture Storage Function - modified Cosella-Dorken's NovaFlexx product inputted into WUFI 6.1 user defined data base.

6) Downward drying - if there is no potential drying to the interior, a self drying roof is not feasible.

To promote downward drying in a wet roofing enclosure, roof membrane with high solar radiation absorption potential and materials with a high potential for permeability are required. Darker membranes used through hygrothermal modeling resulted in greater amounts of drying in a shorter period, whereas the lighter colour membranes were not as effective, especially in cloudy or colder climates. Figure 9, 10,11 and 12 indicate the calculated number of hours to dry 
back to equilibrium. Rating the colour of roof membranes from quickest drying to slowest drying are the black roof membrane, grey roof membrane and white roof membrane. Using materials with high vapour permeable materials will allow drying to the interior, however will also allow for wetting during the heating season in cold climates.

Allowing the self-drying roof enclosure to dry to the interior, the potential for moisture to wet during the heating months is apparent. To reduce the potential of moisture uptake during the heating season a smart membrane is recommended to control the vapour drive in and out of the roofing assembly. In the warmer climates, an air barrier could be used in place of the smart membrane since the vapour drive direction is typically always inward. Permeance of metal deck was tested to ASTM E96 to evaluate the permeance of the metal deck. The permeance of the metal deck averaged out to approximately 1 US perm; however, to increase the drying potential of the metal deck an acoustical or pre-perforated metal deck could be utilized.

The proposed "Ryerson" self-drying roof enclosure does meet ORNL intent on downward drying, yet several scenarios are more effective than others. Roof membrane colour, type of vapour permeable membrane, permeance of metal deck and ventilation in the metal deck flutes all have a definite impact on the drying potential of the self-drying roof enclosure. 


\subsection{CONCUSION}

The speed of planning, design and construction are always increasing which has placed a strain on available resources: resources in terms of financial burden and manpower. The unfortunate result can conceivably be questionable quality. There is a saying in construction that states "Speed, Quality and Cost, you can pick two but you can't have three". With the extensive list of deficiencies identified during and after construction, it appears that the owner often receives one ill-fated result, "Speed". Developing building enclosures that are durable and efficient, even when problems arise, should be the way of the future and how all designers should be thinking. Typically roof enclosures have the biggest litigation potential in the construction industry due to the complexities of design and application. Developing a self-drying roof enclosure would be a giant step forward in minimizing the monetary impact on the owner and the environmental burden on our society.

The development of a self-drying roof has been studied in the past and some promising work on the subject has been completed. As previously stated, ORNL conducted field studies as well as hygrothermal modeling which led to the identification of six performance characteristics required for a self drying roof enclosure. To be classified as a self drying roof enclosure the assembly must follow these six characteristics: decrease in moisture content, minimal moisture uptake during the heating season, the roof enclosure shall not drip water to the interior, must control the movement of vapour, control the movement of water and the roof must be able to dry downward to the interior. These guiding principles were the basis for the designing of the proposed self-drying roof. Small modifications have been made since ORNL's studies due to the performance characteristics of new materials currently on the market.

The proposed self-drying roof enclosure design was created with economics and ease of construction in mind. The roof membrane was to be continuous, have a very low vapour permeable quality and colour to suit the respective climatic zone. The thermal insulation is to be constructed out of a highly vapour permeable mineral wool insulation. ROXUL TopRock was the preferred choice of mineral wool as the material was readily available and had been successfully 
used in Europe for many decades. Handling of the moisture management when the roof enclosure could dry to the interior proved successful with a membrane that changed its permeance based on the ambient RH. Cosella-Dorken NovaFlexx was the product selected to control the moisture loads including the air pressure loads. ASTM E96 testing on the vapour permeance of the smart membrane was conducted on the material to determine suitability. Results showed the smart membrane had a vapour permeable range of 0.79 US perms in low $\mathrm{RH}$ conditions to 9.4 US perms in high RH conditions. Metal deck was used for the substrate because of its light weight and potential vapour permeable characteristics. Perforated metal deck would be a recommended solution however, if a standard metal deck is used, vapour can still transfer through. ASTM E96 testing was conducted on several scenarios of metal deck and the average vapour permeance was 1.0 US perms. Ventilations between the metal deck flutes in an unperforated metal deck assisted in reducing the winter wetting as well as reducing the humid air in the metal deck flutes during drying.

Results from the seventy-eight hygrothermal models proved that the potential for a selfdrying roof enclosure is suitable in almost every location. There are several outliers which show that the self-drying roof enclosure in colder climates with a white membrane were nonfunctional. Though the roof enclosures will still dry over a longer period, the time to dry did not meet the criteria previously identified. The roofs that did not meet the requirements of a self drying roof include; St. John's, NFLD - White Roof, Vancouver (Passive) - White Roof, Fairbanks, AK (Passive) - White Roof (Passive) and St. John's, NFLD - White Roof (Active). The white membrane and the mean cloud cover did not have sufficient energy to drive the moisture downward in the time and quantity indicated by Criteria 1 and Criteria 2 . The remaining seventyfour roof models were predicted to meet the requirements for classification as a self-drying roof enclosure.

With the data provided in this research document it is of the understanding that the proposed "Ryerson" self-drying roof enclosure is possible in North America under certain circumstances. The performance of this self-drying roof enclosure could potentially minimize the 
high rate of litigation and provide the additional benefits of increased resiliency, reduced financial burden for building owners, and result in a reduced impact on the environment. 


\subsection{REFERENCES}

Desjarlais, A. (1995). Self Drying Roofs: What! No Dripping!. Oakridge, Tennessee: Oakridge National Laboratory.

Desjarlais, A, Petrie, T, Childs, P and Atchley, J. (1998). Moisture Studies of a Self-Drying Roof: Tests in a Large Scale Climate Simulator and Results from Thermal and Hygric Models. Oakridge, Tennessee: Oakridge National Laboratory.

Kyle, D and Desjarlais, A. (1994). Assessment of Technologies for Constructing Self-Drying LowSlope Roofs. (ORNL/CON-380). Oakridge, Tennessee: Oakridge National Laboratory.

Desjarlais, A and Byars, N. (1998). Predicting Moisture Problems in Low-Sloped Roofing. Oakridge, Tennessee: Thermal Envelopes VII

Tobiasson, W, Greatorex, A and Van Pelt, D. (1991). New Wetting Curves for Common Roof Insulations. Montreal, Quebec: Third International Symposium on Roofing Technology.

Sandberg, P. (1987). Thermal Resistance of a Wet Mineral Fiber Insulation. Philadelphia, PA: ASTM

Seward, A. (2011). When It Leaks It Pours. Washington, D.C.: The Journal of the American Institute of Architects.

Korsgaard, V, Bunch-Nielsen, T and Rode, Carsten. (1996). The Self-Drying Concept for Flat Roofs. Journal of the Roof Consultants Institute, 1996, Vol XIV, Issue 4, p. 23-31

ASHRAE, Standard 90.1-2016, Energy Standard for Building Except Low-Rise Residential Buildings. (2016). Atlanta, Georgia. www.ashrae.org.

ASTM E96, Standard Test Methods for Water Vapor Transmission of Materials. (2016). West Conshohocken, Pennsylvania. www.astm.org. 


\subsection{APPENDIX A - Increased Heat Loss Equation, Example and Solution}

\begin{tabular}{|c|c|c|c|c|}
\hline Insulation & $\begin{array}{c}k_{d y} \\
\left(W / m^{\circ} \cdot{ }^{\circ}\right)\end{array}$ & $k_{\text {med }} / k_{d y}$ & $\begin{array}{c}\text { Fraction of total } \\
\text { installed: } 1983-88 \text { [4] }\end{array}$ & $\begin{array}{c}\text { Fraction of total } \\
\text { installed: } 1992 \text { [5] }\end{array}$ \\
\hline Polyisocyanurate & 0.021 & 1.14 & 0.28 & 0.49 \\
\hline $\begin{array}{l}\text { Expanded } \\
\text { polystyrene }\end{array}$ & 0.034 & 1.22 & 0.08 & 0.12 \\
\hline $\begin{array}{l}\text { Extruded } \\
\text { polystyrene }\end{array}$ & 0.029 & 1.27 & 0.08 & 0.06 \\
\hline Phenolic & 0.016 & 1.30 & 0.00 & 0.03 \\
\hline Polyurethane & 0.027 & 1.14 & 0.05 & 0.00 \\
\hline Wood fiber & 0.058 & 1.76 & 0.18 & 0.00 \\
\hline Perlite & 0.052 & 2.14 & 0.10 & 0.25 \\
\hline Glass fiber & 0.036 & 2.35 & 0.22 & 0.07 \\
\hline
\end{tabular}

Table 1 - Average Ratio of Wet to Dry Thermal Conductivity for Common Insulation Types

To demonstrate the potential impact of wet insulation over a heating season, Table 1 and Equation 1 are required for prediction. Chart data and Calculation was identified in the ORNL document "Assessment of Technologies for Constructing Self-Drying Low-Slope Roofs" to assist the industry with the prediction of increased heat transfer due to wet thermal insulation. The following example illustrates how to calculate the increased thermal transfer due to wet mineral wool insulation in a roof located in Toronto, ON. Though Table 1 does not have a value for mineral wool the value of 2.35 for mineral fiber will be used. Further work to calculate the Average Ratio of Wet to Dry Thermal Conductivity for mineral wool (ROXUL TopRock) should be conducted. This calculation method can be utilised to predict the increased heat loss from the provided hygrothermal models in the various cities across North America. 


\section{Equation 1}

$\mathrm{Q}_{w e t}=\mathrm{Q}_{d r y}\left[\mathrm{k}_{w e t} / \mathrm{k}_{d r y}\right]$

\section{Equation Key}

$Q_{d r y}$ - Calculated Dry Roofing Enclosure Heat Loss over Heating Season

$\left[\mathrm{k}_{w e t} / \mathrm{k}_{d r y}\right]$ - Average Ratio of Wet to Dry Thermal Conductivity

$\mathrm{Q}_{\text {wet }}-$ Calculated Excess Heat Loss due to Presence of Moisture

\section{Example 1}

Determining the increased predicted heat flux for a wet roof enclosure during a typical Toronto heating season, the following steps shall be followed: Step 1) Determine the dry heat flux of roof enclosure in question; Step 2) Apply the average ratio of wet to dry thermal conductivity coefficient to the calculated dry heat flux; and Step 3) Subtract the dry heat flux value from the wet heat flux value. The difference between the two is the predicted increase in heat loss. ORNL indicates that though these are calculated values, the results are reasonably accurate. Accuracy in the prediction will be jeopardized if the thermal conductivity of the insulation is dependant on temperature or the averaging temperature period is too long.

\section{Solution 1}

\section{Step 1}

$\mathrm{U}$ value of dry assembly $=0.24 \mathrm{~W} /\left(\mathrm{m}^{2} \mathrm{~K}\right)$

Average Toronto Winter Temperature $=2.5^{\circ} \mathrm{C}$

Average Interior Temperature $=21^{\circ} \mathrm{C}$

$q / A=U\left(t_{i}-t_{o}\right)=q / A=0.24 \mathrm{~W} /\left(\mathrm{m}^{2} \mathrm{~K}\right) \times 18.5^{\circ} \mathrm{C}=4.44 \mathrm{~W} / \mathrm{m}^{2}$

\section{Step 2}

$\mathrm{Q}_{\text {wet }}=\mathrm{Q}_{\text {dry }}\left[\mathrm{k}_{\text {wet }} / \mathrm{k}_{d r y}\right]=\mathrm{Q}_{\text {wet }}=4.44 \mathrm{~W} / \mathrm{m}^{2}[2.35]=10.43 \mathrm{~W} / \mathrm{m}^{2}$

\section{Step 3}

$\mathrm{Q}_{\text {wet }}=\mathrm{Q}_{d r y}=10.43 \mathrm{~W} / \mathrm{m}^{2}-4.44 \mathrm{~W} / \mathrm{m}^{2}=5.99 \mathrm{~W} / \mathrm{m} 2$

The calculated increased heat loss in a wet $150 \mathrm{~mm}$ mineral fibre roof enclosure located in Toronto over a heating season (October to April) resulted in an additional $5.99 \mathrm{~W} / \mathrm{m}^{2}$ loss. 
10.0 APPENDIX B - ASTM E96 Graph Results

Cosella-Dorken Delta NovaFlexx - Dry Cup

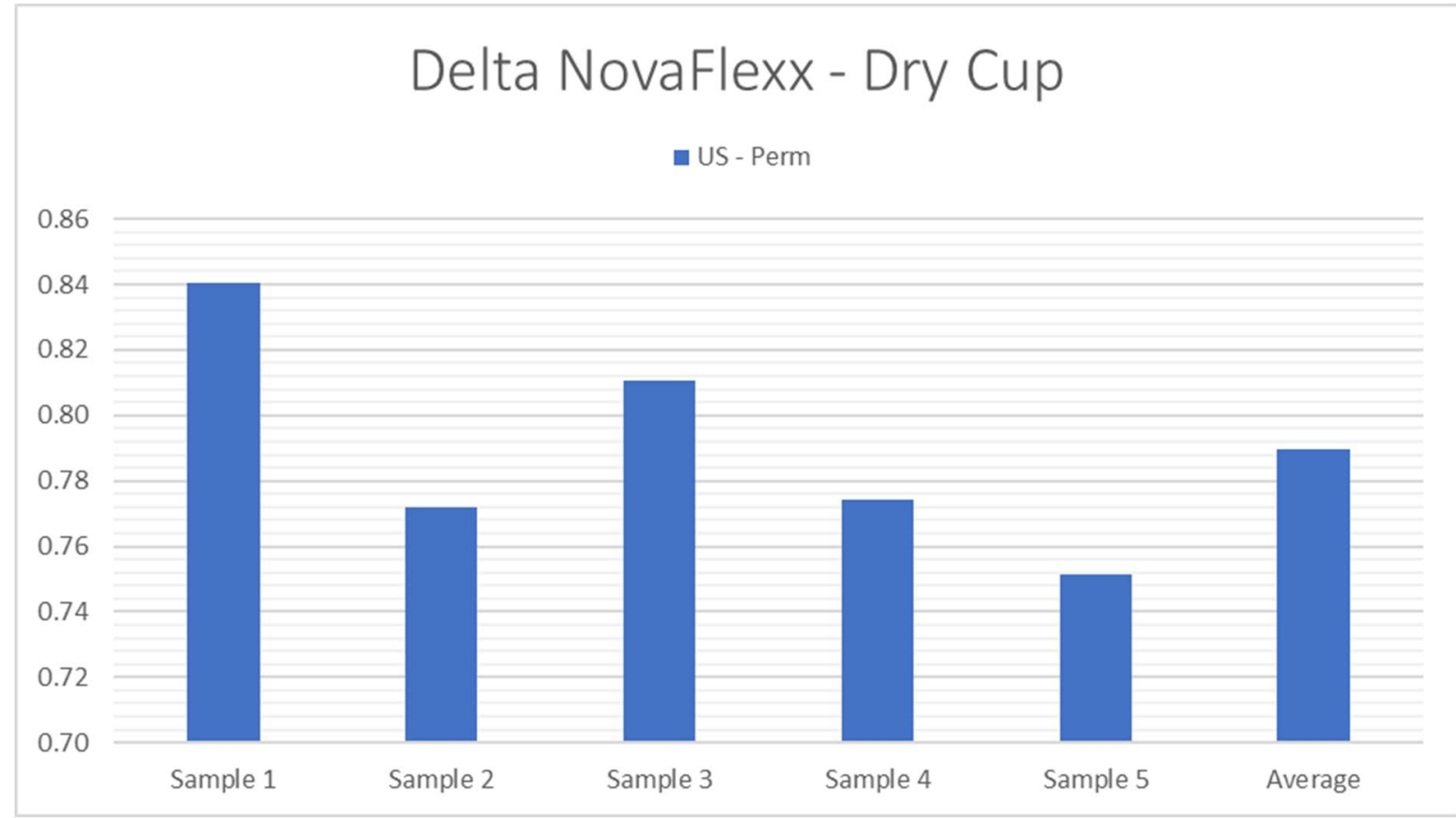

Cosella-Dorken Delta NovaFlexx - Wet Cup

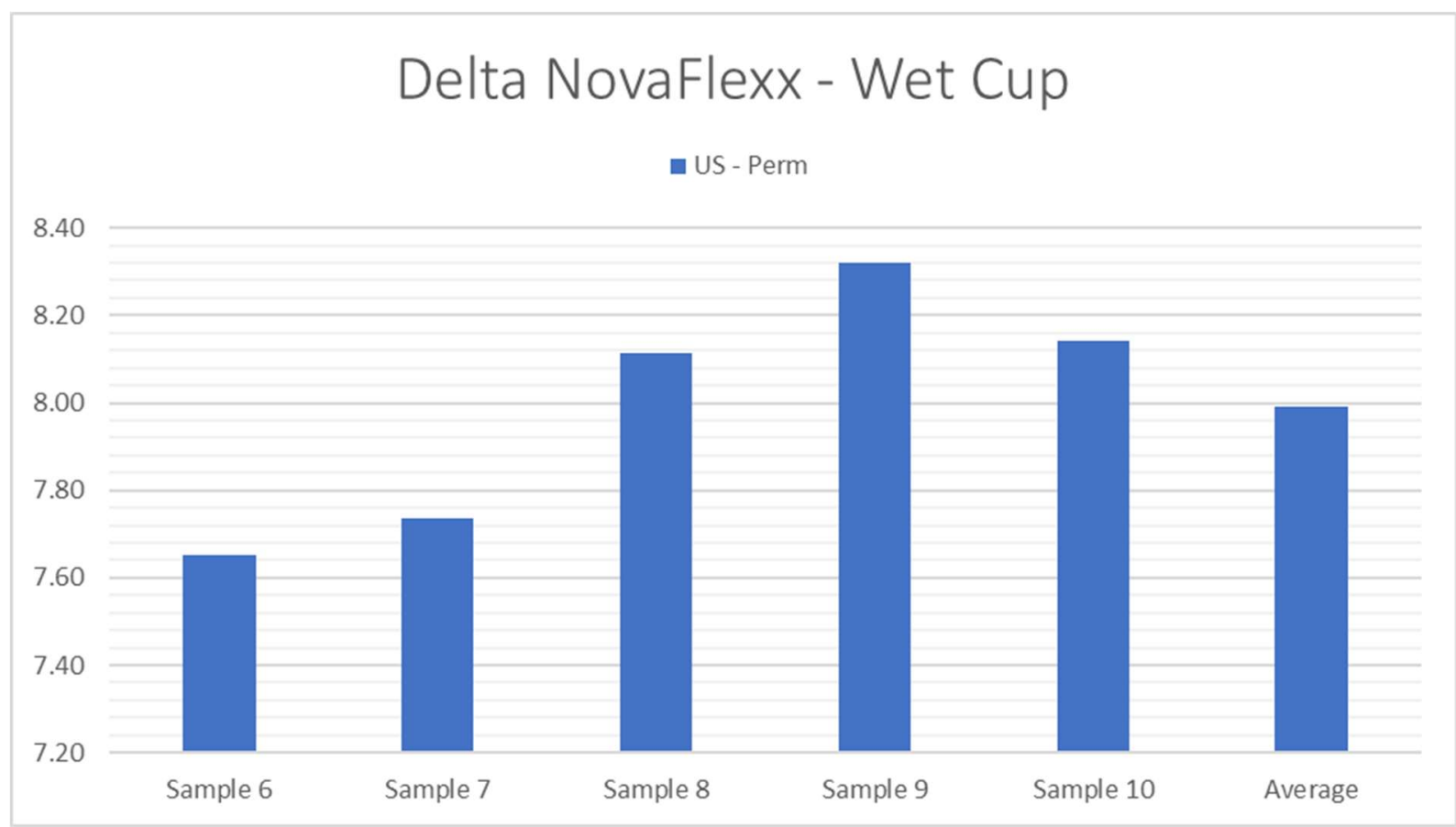


Cosella-Dorken Delta NovaFlex - High RH

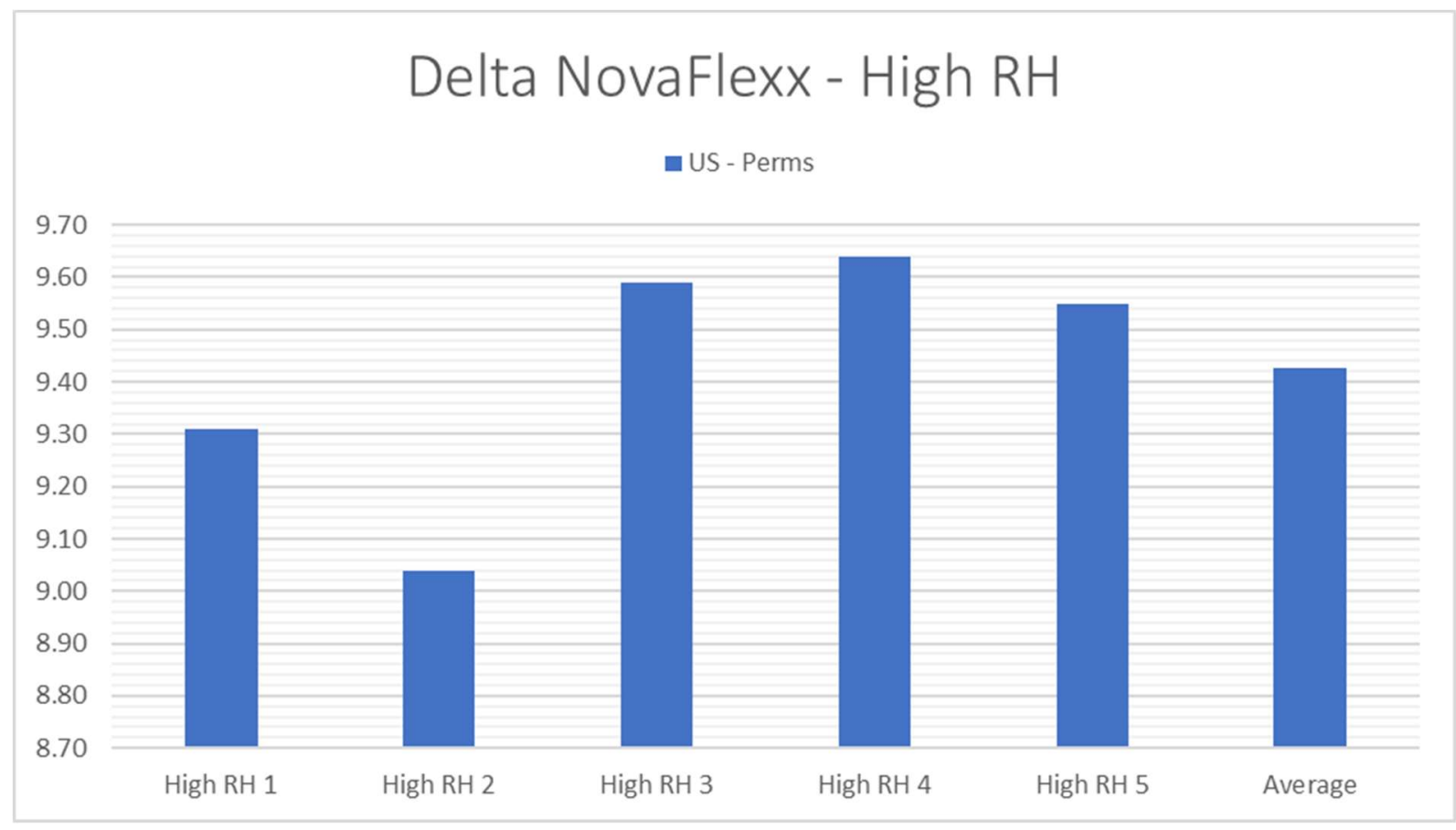

\section{Metal Deck - Wet Cup}

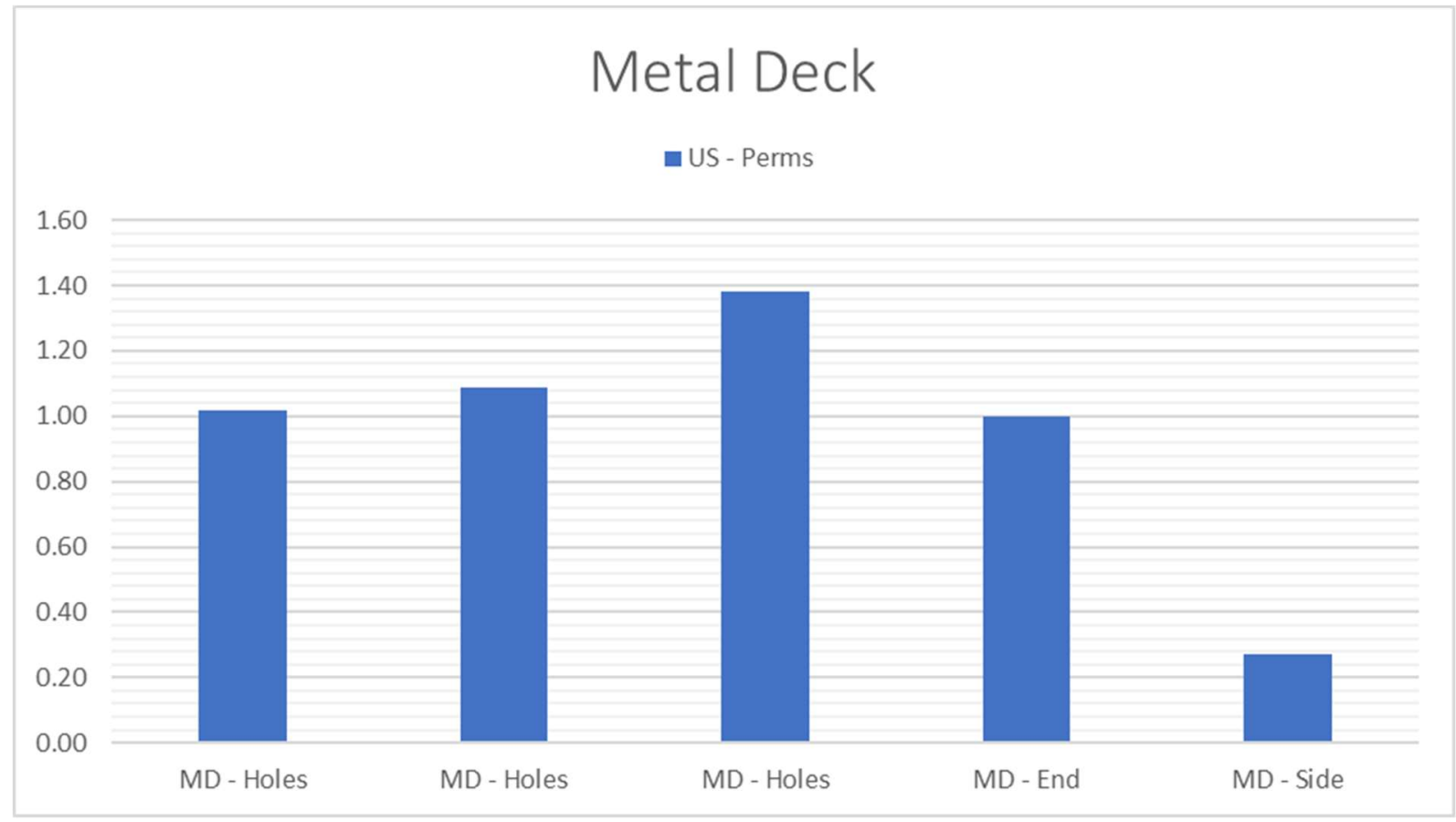




\subsection{APPENDIX C - Metal Deck E96 Sample Preparation}

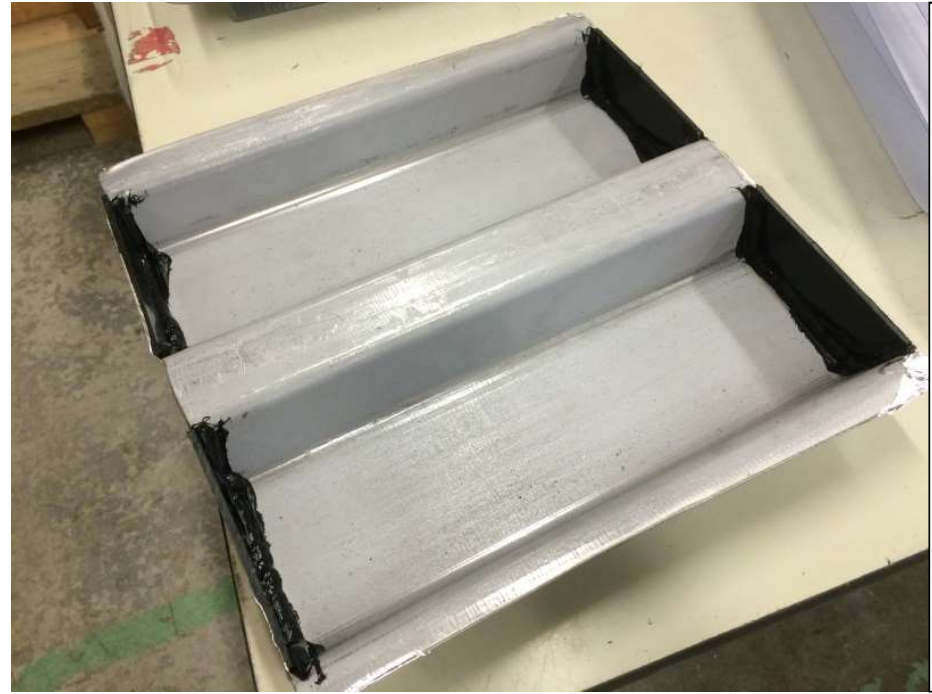

Step 1 in the construction of the metal deck water vapour permeance (WVP) test.

Install plastic spacer to block off the end of the metal deck flutes. Apply vapour resistant caulking at the metal deck and plastic spacer interface.

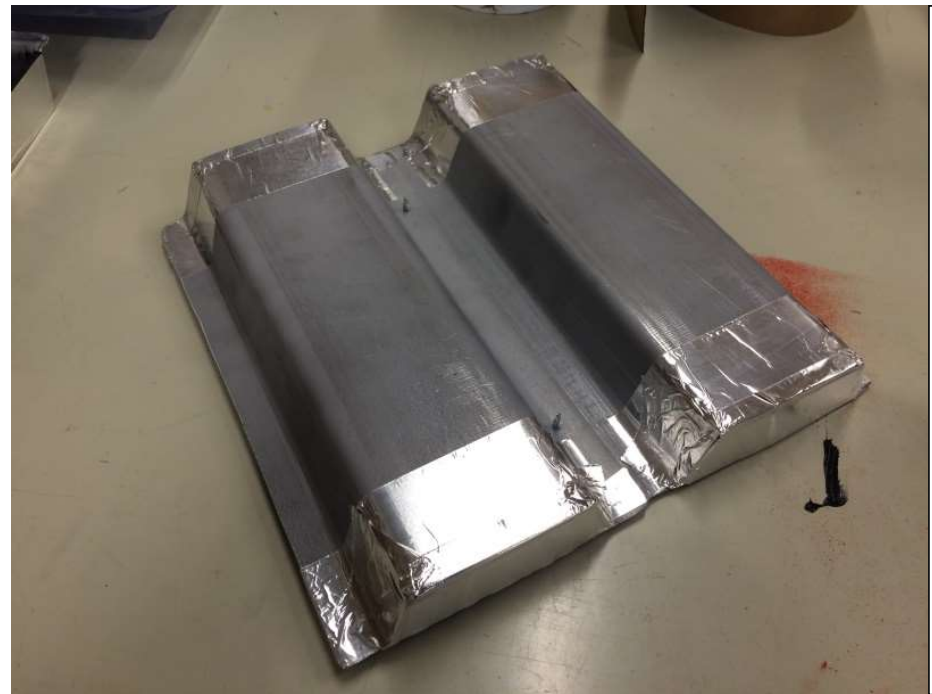

Step 2 in the construction of the metal deck water vapour permeance (WVP) test.

Seal the exterior side of the metal deck and plastic spacer with vapour impermeable tape. Tape was used as a redundancy to ensure no air or vapour leakage can take place.

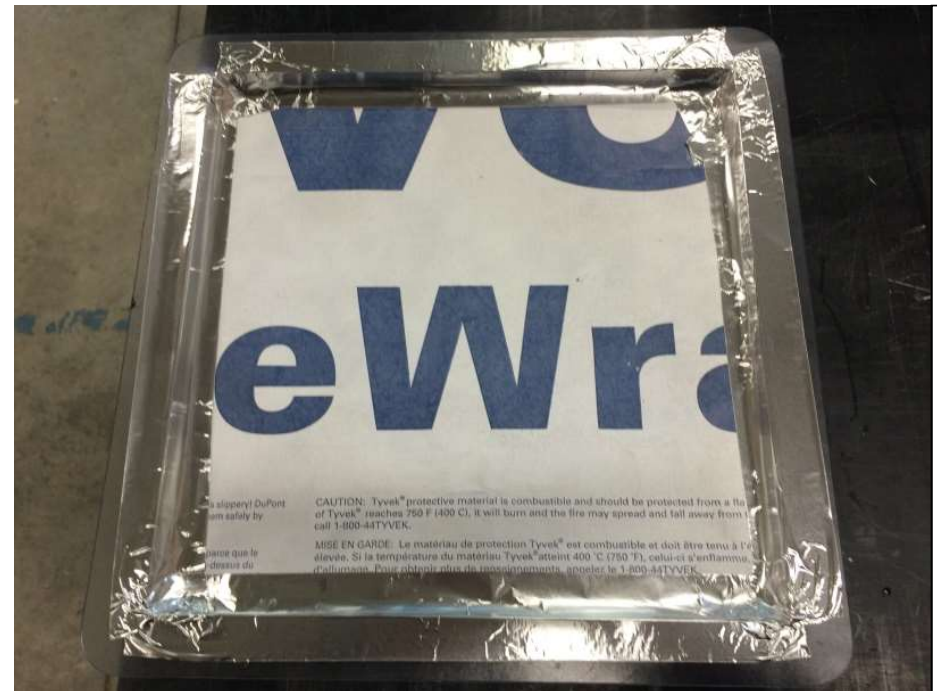

Step 3 in the construction of the metal deck water vapour permeance (WVP) test.

Place plastic grate in bottom of plastic pan and pour in distilled water. Tyvek was used to eliminate air leakage into the deck above. Vapour impermeable tape was used to secure the Tyvek to the plastic pan. 

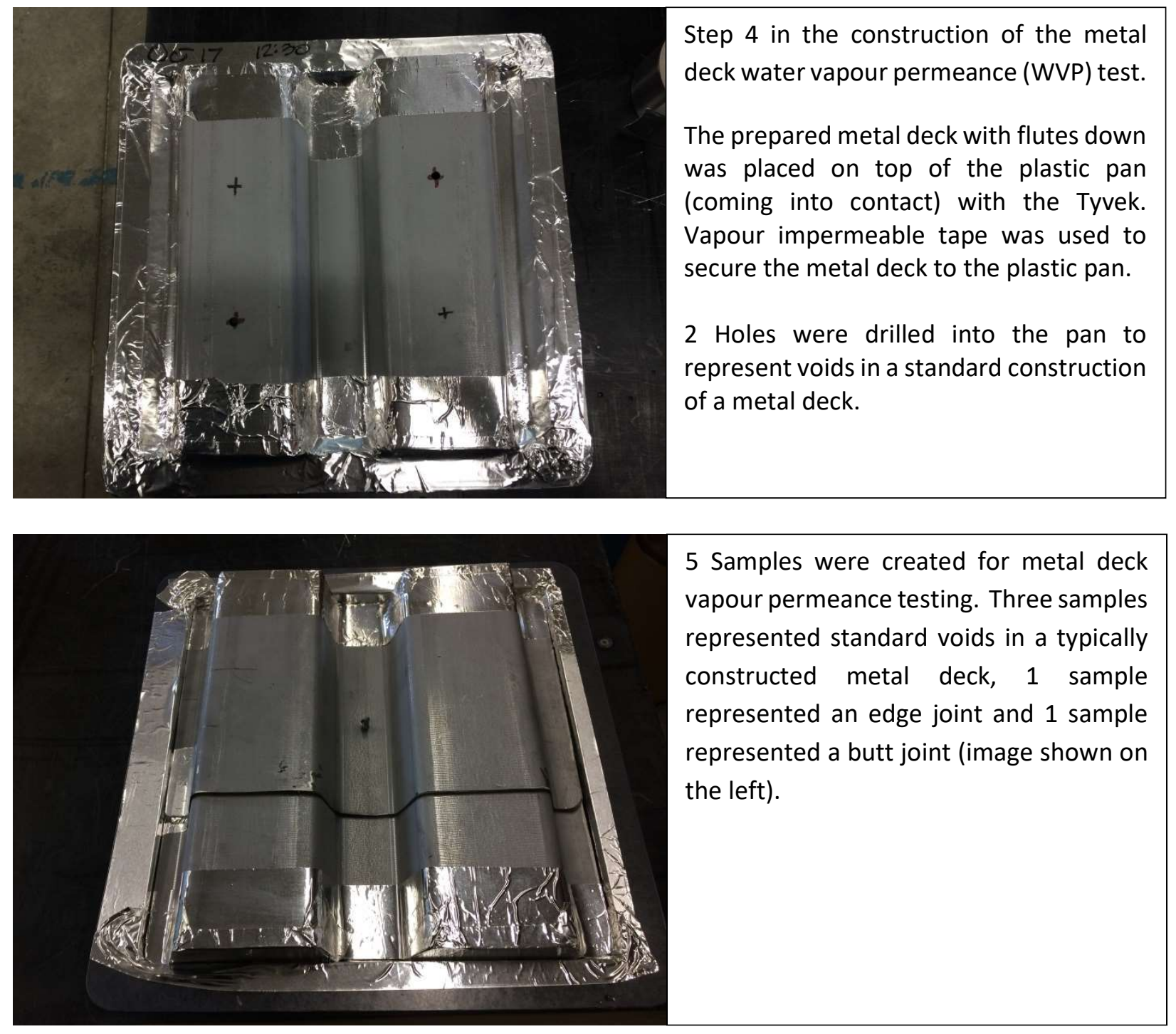


\subsection{APPENDIX D - WUFI 6.1 Model Input Parameters}

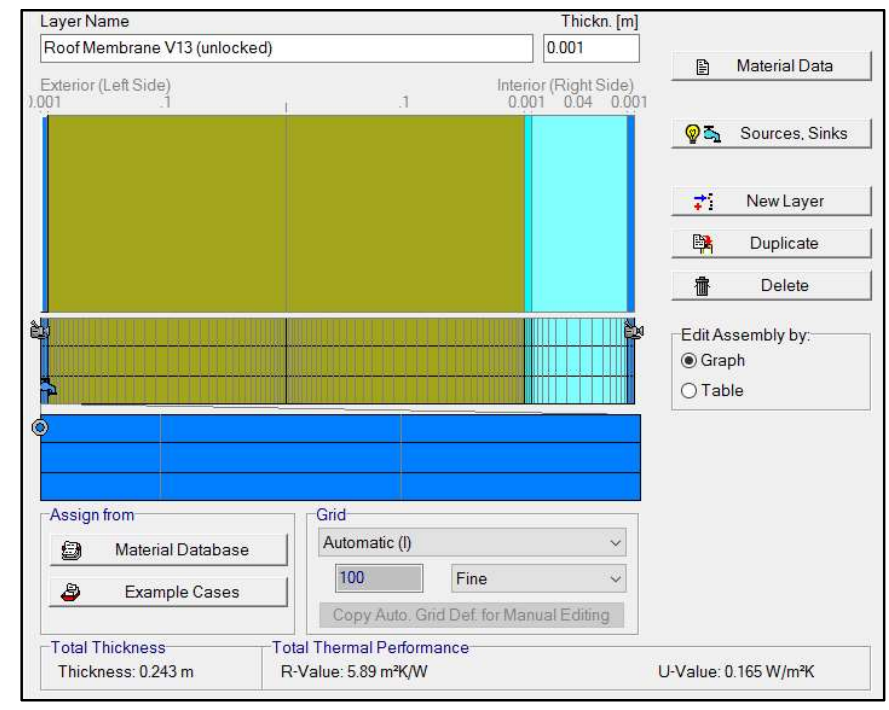

Component Segment, ASSEMBLY sub segment indicates the roof section design for the proposed self drying roof enclosure. The roof enclosure components listed left to right include; Roof Membrane V13, 2 layers ROXUL TopRock, Cosella-Dorken NovaFlexx, generic air space and generic vapour barrier representing a metal deck (1 Perm). A moisture source was placed between the roofing membrane and the top surface of the mineral wool insulation. The moisture source introduced $750 \mathrm{ml}$ of water at the interface April $1^{\text {st }}$.

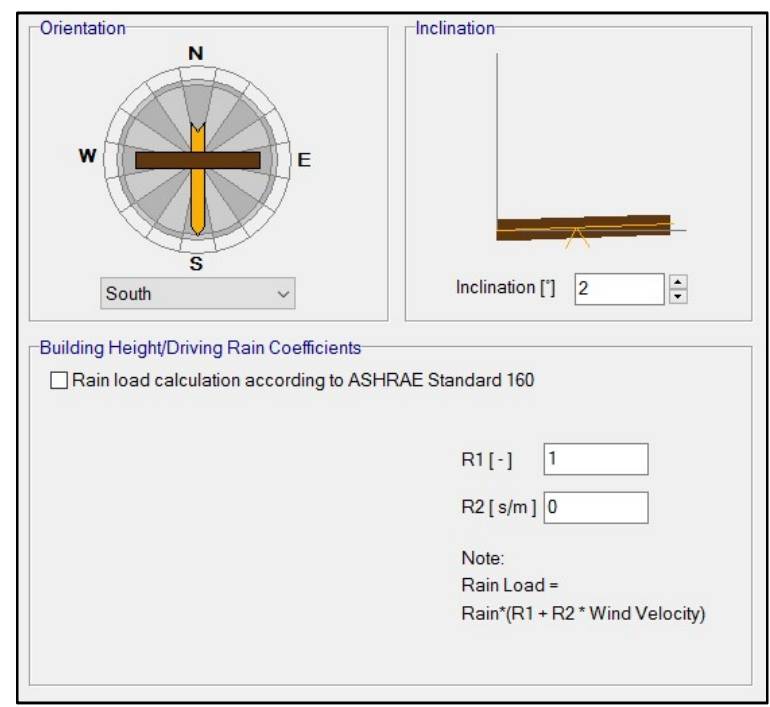


Component Segment, ORIENTATION sub segment to the left indicates the roof orientation and inclination. South orientation with an inclination of 2 was chosen based on the conditions that it would be the worst-case scenario for a flat roof. Orientation with an inclination of 0 is irrelevant since the roof would get the same radiation no matter what orientation was chosen. The $2 \%$ inclination represents a standard $2 \%$ slope on a typical roof.

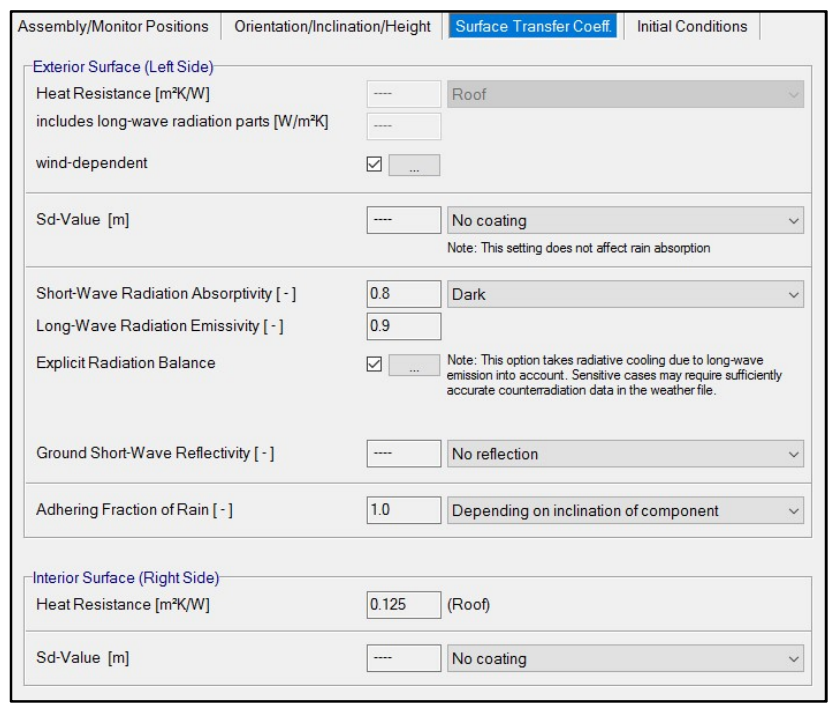

Component Segment, SURFACE TRANSFER COEFFICIENTS sub segment to the left indicates the air films, vapour retarding coatings and membranes, radiation and adhering rain. Exterior air film was set to 0 as winds are constantly moving on the roof. I did not use additional coatings on the roof enclosure. Short wave radiation was selected based on the colour of the membrane ( 0.3 for White, 0.6 for Grey and 0.8 for Black). Mean cloud index listed in the explicit radiation balance was set to the number provided in local climatic data. The adhering fraction of rain was set to 1 as it's a more realistic number based on the field experience. The interior did not have a coating but the interior air film was set to 0.125 . 


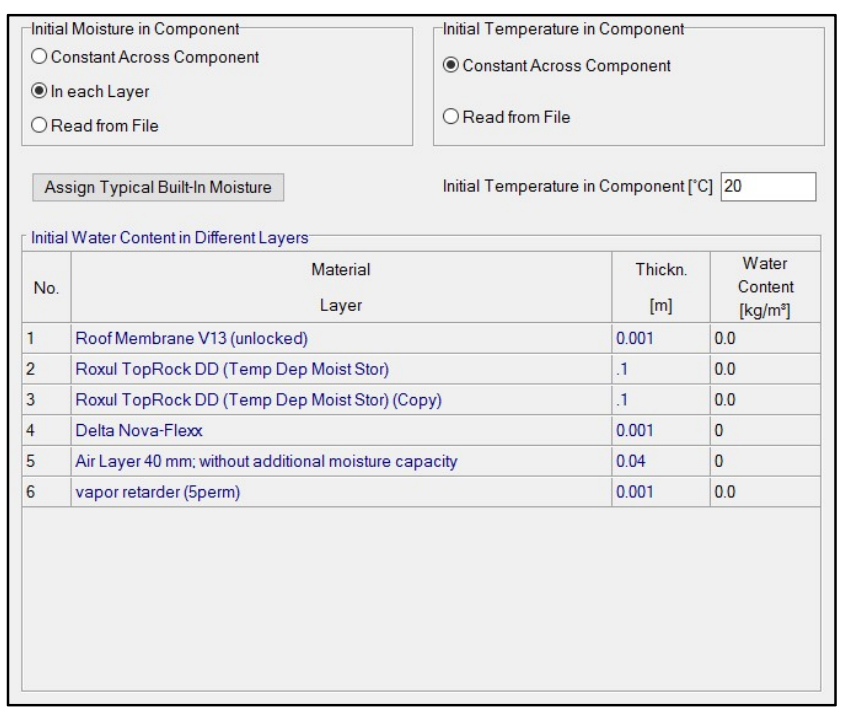

Component Segment, INITIAL CONDITIONS sub segment to the left indicates typical built in moisture and initial temperature in component. To see the isolated drying potential of the roof enclosure all initial water content in the material was set to 0 . The initial start of the model was October $1^{\text {st }}$ so a reasonable temperature for the climate zones was $20^{\circ} \mathrm{C}$.

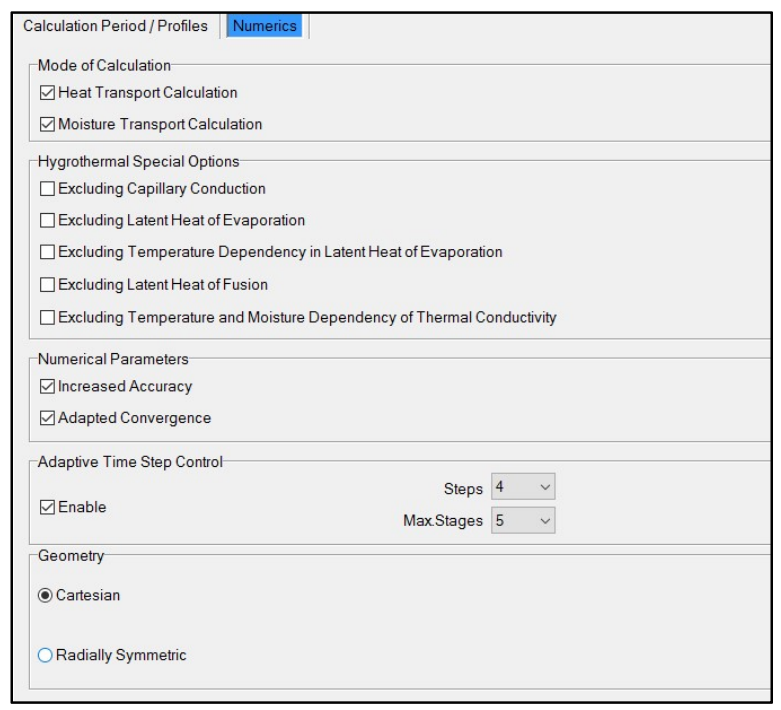

Control Segment, CALCULATION PERIOD and NUMERICS sub segment to the left indicates the length in time the model is to run and under what type of calculation. The time frame for the testing of the proposed self-drying roof enclosure was set for one year or 8760 hours. Included in the year long calculation was the transport of heat and moisture under increased accuracy. 


\subsection{APPENDIX E - ASTM E96 Laboratory Results}

MRP Vapor Permeance Test

Method: Modified ASTM E96 Dry Cup

\begin{tabular}{|llll|}
\hline Material Description & & \\
Sample ID & 1 & & \\
Description & Cosella Dorken Nova Flexx & \\
Length & 0.153 & $(\mathrm{~m})$ & \\
Width & 0.149 & $(\mathrm{~m})$ & \\
Diameter & & $(\mathrm{m})$ & \\
Area & 0.0228 & $\left(\mathrm{~m}^{2}\right)$ & \\
Mass & & $(\mathrm{kg})$ & \\
Density & & $\left(\mathrm{kg} / \mathrm{m}^{3}\right)$ & \\
Sample Thickness & 0.001 & $(\mathrm{~m})$ & \\
Film Thickness & & $\begin{array}{l}\text { wet mils } \\
\left(\mathrm{m}^{3}\right)\end{array}$ & \\
Volume & & & \\
\hline
\end{tabular}

Material / Info

\begin{tabular}{|lcll|}
\hline Analysis Results & & & \\
Slope & 0.154 & $(\mathrm{~g} /$ day $)$ & Notes \\
Intercept & 0.2448 & & \\
$\mathrm{R}^{2}$ & 0.9982 & & \\
& & & \\
Cup Vp & 0 & $(\mathrm{~Pa})$ & assumed \\
Room Vp & 1632 & $(\mathrm{~Pa})$ & measured \\
delta Vp & -1632 & $(\mathrm{~Pa})$ & \\
& & & \\
Permeance $\left(\mathrm{M}_{\mathrm{T}}\right)$ & 47.9 & $\left(\mathrm{ng} / \mathrm{Pa} \cdot \mathrm{m}^{2} \cdot \mathrm{s}\right)$ \\
& $\mathbf{0 . 8 4}$ & $\mathrm{US}-\mathrm{perms}$ \\
& 0.84 & $\mathrm{US}-$ perms (corrected) \\
\hline
\end{tabular}

\begin{tabular}{|c|c|c|c|c|c|}
\hline Data & & & & & using modified ASTM E96 \\
\hline Date and Time & $\begin{array}{c}\text { Elapsed } \\
\text { Time } \\
\text { (days) }\end{array}$ & $\begin{array}{l}\text { Measured } \\
\text { Mass } \\
\text { (grams) }\end{array}$ & $\begin{array}{c}\Delta \text { mass } \\
\text { (grams) }\end{array}$ & $\begin{array}{l}\text { Included in } \\
\text { Curve-fit }\end{array}$ & Remarks \\
\hline 9/19/2016 10:00 & 0.00 & 383.39 & 0.00 & & Start of Test \\
\hline $9 / 22 / 201610: 30$ & 3.02 & 384.1 & 0.71 & & \\
\hline $9 / 23 / 201611: 40$ & 4.07 & 384.5 & 1.11 & & \\
\hline $9 / 26 / 201610: 00$ & 7.00 & 384.7 & 1.31 & Y & \\
\hline $9 / 27 / 201612: 15$ & 8.09 & 384.9 & 1.51 & Y & \\
\hline $9 / 28 / 20169: 00$ & 8.96 & 385 & 1.61 & Y & \\
\hline $9 / 29 / 201615: 30$ & 10.23 & 385.2 & 1.81 & Y & \\
\hline $10 / 3 / 201612: 00$ & 14.08 & 385.8 & 2.41 & Y & \\
\hline $10 / 4 / 201615: 15$ & 15.22 & 386 & 2.6 & Y & \\
\hline $10 / 5 / 20168: 55$ & 15.95 & 386.1 & 2.7 & Y & \\
\hline $10 / 6 / 201611: 30$ & 17.06 & 386.2 & 2.8 & Y & \\
\hline $10 / 12 / 201610: 30$ & 23.02 & 387.3 & 3.9 & Y & \\
\hline $10 / 17 / 201614: 30$ & 28.19 & 387.9 & 4.5 & Y & \\
\hline $10 / 18 / 201610: 00$ & 29.00 & 388.1 & 4.7 & $Y$ & \\
\hline
\end{tabular}

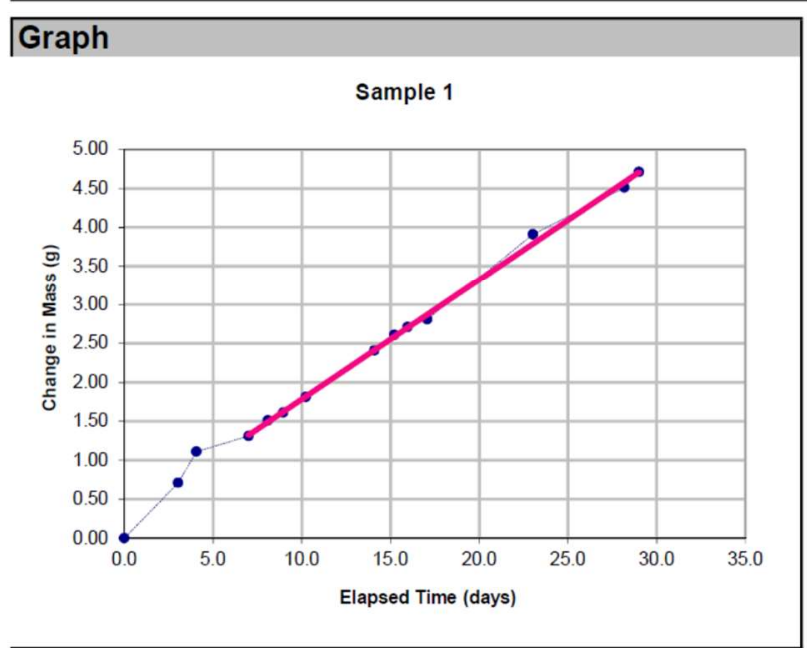

\begin{tabular}{|l|}
\hline Testing Photo \\
\hline
\end{tabular}


MRP Vapor Permeance Test

Material / Info

Method: Modified ASTM E96 Dry Cup

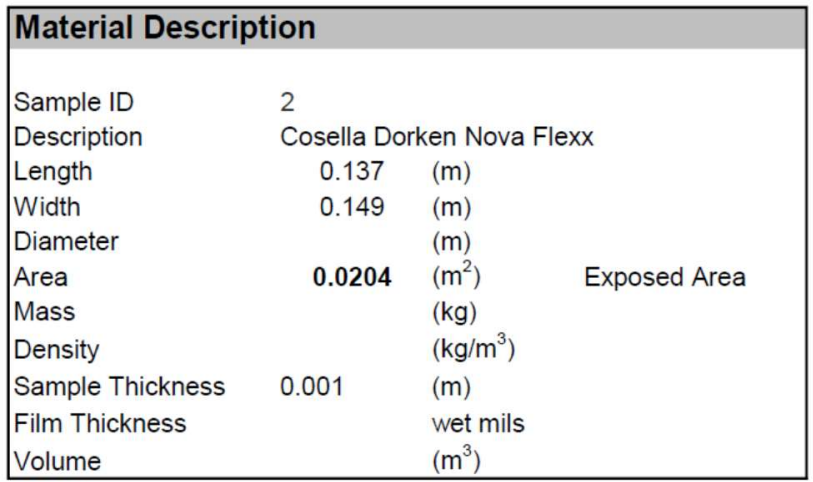

\begin{tabular}{|c|c|c|c|}
\hline \multicolumn{4}{|c|}{ Analysis Results } \\
\hline Slope & 0.127 & (g/day) & Notes \\
\hline Intercept & 0.0901 & & \\
\hline$R^{2}$ & 0.9962 & & \\
\hline Cup Vp & 0 & $(\mathrm{~Pa})$ & assumed \\
\hline Room Vp & 1632 & $(\mathrm{~Pa})$ & measured \\
\hline delta $V p$ & -1632 & $(\mathrm{~Pa})$ & \\
\hline \multirow[t]{3}{*}{ Permeance $\left(\mathrm{M}_{\mathrm{T}}\right)$} & 44.0 & \multicolumn{2}{|c|}{$\left(\mathrm{ng} / \mathrm{Pa} \cdot \mathrm{m}^{2} \cdot \mathrm{s}\right)$} \\
\hline & 0.77 & \multicolumn{2}{|c|}{ US-perms } \\
\hline & 0.77 & \multicolumn{2}{|c|}{ US-perms (corrected) } \\
\hline
\end{tabular}

\begin{tabular}{|c|c|c|c|c|c|}
\hline Data & & & & & using modified ASTM E96 \\
\hline Date and Time & $\begin{array}{l}\text { Elapsed } \\
\text { Time } \\
\text { (days) }\end{array}$ & $\begin{array}{l}\text { Measured } \\
\text { Mass } \\
\text { (grams) }\end{array}$ & $\begin{array}{c}\Delta \text { mass } \\
\text { (grams) }\end{array}$ & $\begin{array}{l}\text { Included in } \\
\text { Curve-fit }\end{array}$ & Remarks \\
\hline $9 / 21 / 201610: 53$ & 0.00 & 250.3 & 0.00 & & Start of Test \\
\hline $9 / 22 / 201610: 30$ & 0.98 & 250.4 & 0.10 & & \\
\hline $9 / 23 / 201611: 40$ & 2.03 & 250.5 & 0.20 & & \\
\hline 9/26/2016 10:00 & 4.96 & 251.01 & 0.71 & Y & \\
\hline $9 / 27 / 201612: 15$ & 6.06 & 251.3 & 1.00 & Y & \\
\hline 9/28/2016 9:00 & 6.92 & 251.2 & 0.90 & Y & \\
\hline $9 / 29 / 201615: 30$ & 8.19 & 251.4 & 1.10 & Y & \\
\hline $10 / 3 / 201612: 00$ & 12.05 & 251.9 & 1.60 & Y & \\
\hline $10 / 4 / 201615: 15$ & 13.18 & 252 & 1.7 & Y & \\
\hline $10 / 5 / 20168: 55$ & 13.92 & 252.1 & 1.8 & Y & \\
\hline $10 / 6 / 201611: 30$ & 15.03 & 252.33 & 2.0 & Y & \\
\hline $10 / 12 / 201610: 30$ & 20.98 & 253.1 & 2.8 & Y & \\
\hline $10 / 17 / 201614: 30$ & 26.15 & 253.7 & 3.4 & Y & \\
\hline $10 / 18 / 201610: 00$ & 26.96 & 253.8 & 3.5 & $Y$ & \\
\hline
\end{tabular}

\section{Graph}

Sample 2

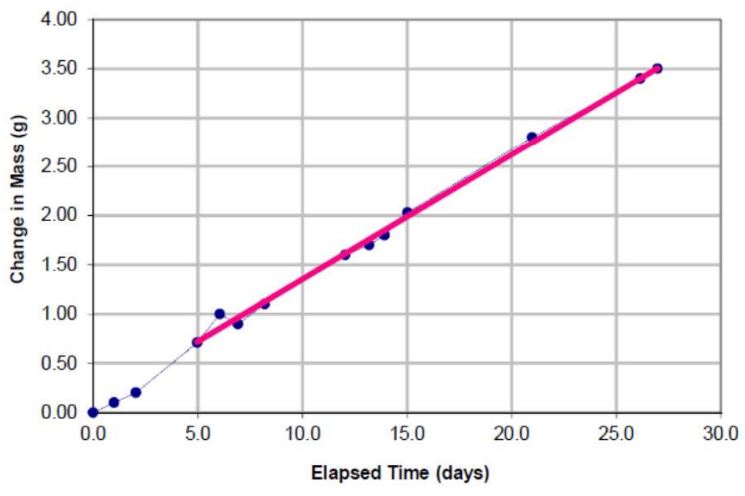

Testing Photo 
MRP Vapor Permeance Test

Material / Info

Method: Modified ASTM E96 Dry Cup

Data:

\begin{tabular}{|c|c|c|c|}
\hline \multicolumn{4}{|c|}{ Material Description } \\
\hline Sample ID & \multicolumn{3}{|l|}{3} \\
\hline Description & \multicolumn{3}{|c|}{ Cosella Dorken Nova Flexx } \\
\hline Length & 0.142 & (m) & \\
\hline Width & 0.149 & (m) & \\
\hline Diameter & & (m) & \\
\hline Area & 0.0212 & $\left(m^{2}\right)$ & Exposed Area \\
\hline Mass & & $(\mathrm{kg})$ & \\
\hline Density & & $\left(\mathrm{kg} / \mathrm{m}^{3}\right)$ & \\
\hline Sample Thickness & 0.001 & $(\mathrm{~m})$ & \\
\hline Film Thickness & & wet mils & \\
\hline Volume & & $\left(m^{3}\right)$ & \\
\hline
\end{tabular}

\begin{tabular}{|lcll|}
\hline Analysis Results & & & \\
& & & \\
Slope & 0.138 & $(\mathrm{~g} /$ day $)$ & Notes \\
Intercept & -0.0130 & & \\
$R^{2}$ & 0.9983 & & \\
& & & \\
Cup Vp & 0 & $(\mathrm{~Pa})$ & assumed \\
Room Vp & 1632 & $(\mathrm{~Pa})$ & measured \\
delta $\mathrm{Vp}$ & -1632 & $(\mathrm{~Pa})$ & \\
& & & \\
Permeance $\left(\mathrm{M}_{\mathrm{T}}\right)$ & 46.1 & $\left(\mathrm{ng} / \mathrm{Pa} \cdot \mathrm{m}^{2} \cdot \mathrm{s}\right)$ \\
& 0.81 & US-perms \\
& 0.81 & US-perms (corrected) \\
\hline
\end{tabular}

\begin{tabular}{|c|c|c|c|c|c|}
\hline Data & & & & & using modified ASTM E96 \\
\hline Date and Time & $\begin{array}{l}\text { Elapsed } \\
\text { Time } \\
\text { (days) }\end{array}$ & $\begin{array}{l}\text { Measured } \\
\text { Mass } \\
\text { (grams) }\end{array}$ & $\begin{array}{c}\Delta \text { mass } \\
\text { (grams) }\end{array}$ & $\begin{array}{c}\text { Included in } \\
\text { Curve-fit }\end{array}$ & Remarks \\
\hline $9 / 21 / 201610: 53$ & 0.00 & 217.1 & 0.00 & & Start of Test \\
\hline $9 / 22 / 201610: 30$ & 0.98 & 217.1 & 0.00 & & \\
\hline $9 / 23 / 201611: 40$ & 2.03 & 217.3 & 0.20 & Y & \\
\hline 9/26/2016 10:00 & 4.96 & 217.8 & 0.70 & Y & \\
\hline 9/27/2016 12:15 & 6.06 & 217.93 & 0.83 & $\mathrm{Y}$ & \\
\hline 9/28/2016 9:00 & 6.92 & 218 & 0.90 & $\mathrm{Y}$ & \\
\hline $9 / 29 / 201615: 30$ & 8.19 & 218.2 & 1.10 & $\mathrm{Y}$ & \\
\hline $10 / 3 / 201612: 00$ & 12.05 & 218.8 & 1.70 & $Y$ & \\
\hline $10 / 4 / 201615: 15$ & 13.18 & 218.9 & 1.8 & Y & \\
\hline $10 / 5 / 20168: 55$ & 13.92 & 219 & 1.9 & Y & \\
\hline $10 / 6 / 201611: 30$ & 15.03 & 219.23 & 2.1 & Y & \\
\hline $10 / 12 / 2016 \quad 10: 30$ & 20.98 & 220 & 2.9 & Y & \\
\hline $10 / 17 / 201614: 30$ & 26.15 & 220.6 & 3.5 & Y & \\
\hline $10 / 18 / 201610: 00$ & 26.96 & 220.8 & 3.7 & Y & \\
\hline
\end{tabular}

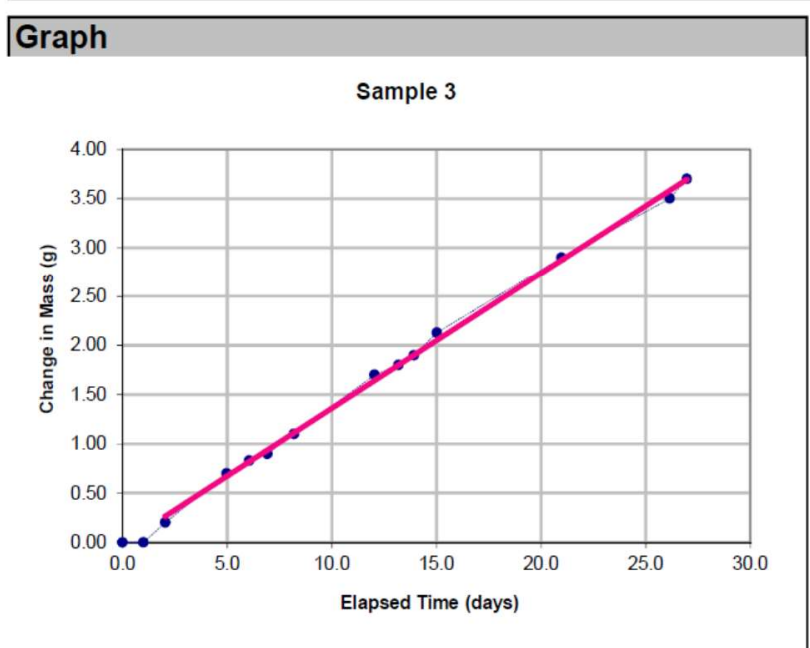

Testing Photo 
MRP Vapor Permeance Test

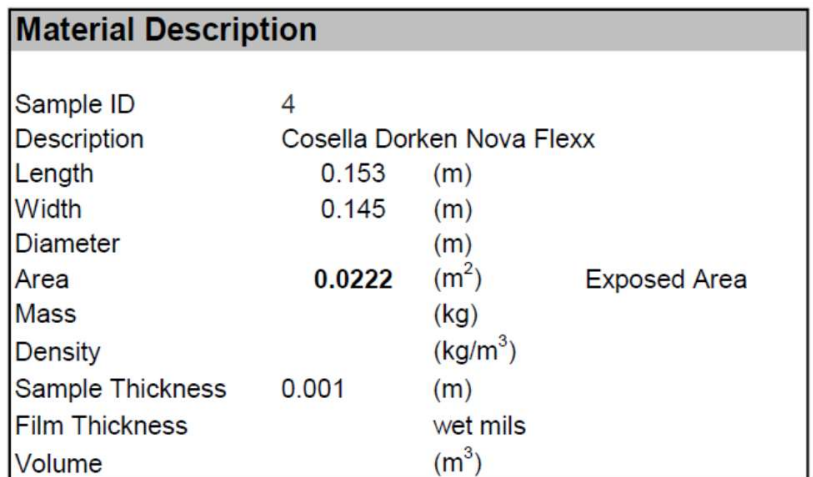

\begin{tabular}{|lcll|}
\hline Analysis Results & & & \\
& & & \\
Slope & 0.138 & $(\mathrm{~g} /$ day $)$ & Notes \\
Intercept & -0.0297 & & \\
$\mathrm{R}^{2}$ & 0.9987 & & \\
& & & \\
Cup Vp & 0 & $(\mathrm{~Pa})$ & assumed \\
Room Vp & 1632 & $(\mathrm{~Pa})$ & measured \\
delta Vp & -1632 & $(\mathrm{~Pa})$ & \\
& & & \\
Permeance $\left(\mathrm{M}_{\mathrm{T}}\right)$ & 44.1 & $\left(\mathrm{ng} / \mathrm{Pa} \cdot \mathrm{m}^{2} \cdot \mathrm{s}\right)$ \\
& 0.77 & US-perms \\
& 0.77 & US-perms (corrected) \\
\hline
\end{tabular}

\begin{tabular}{|c|c|c|c|c|c|}
\hline Data & & & & & using modified ASTM E96 \\
\hline Date and Time & $\begin{array}{l}\text { Elapsed } \\
\text { Time } \\
\text { (days) }\end{array}$ & $\begin{array}{l}\text { Measured } \\
\text { Mass } \\
\text { (grams) }\end{array}$ & $\begin{array}{c}\Delta \text { mass } \\
\text { (grams) }\end{array}$ & $\begin{array}{l}\text { Included in } \\
\text { Curve-fit }\end{array}$ & Remarks \\
\hline $9 / 21 / 201610: 53$ & 0.00 & 220.6 & 0.00 & & Start of Test \\
\hline $9 / 22 / 201610: 30$ & 0.98 & 220.6 & 0.00 & & \\
\hline $9 / 23 / 201611: 40$ & 2.03 & 220.8 & 0.20 & Y & \\
\hline $9 / 26 / 201610: 00$ & 4.96 & 221.28 & 0.68 & Y & \\
\hline $9 / 27 / 201612: 15$ & 6.06 & 221.42 & 0.82 & Y & \\
\hline 9/28/2016 9:00 & 6.92 & 221.5 & 0.90 & Y & \\
\hline $9 / 29 / 201615: 30$ & 8.19 & 221.7 & 1.10 & Y & \\
\hline $10 / 3 / 201612: 00$ & 12.05 & 222.2 & 1.60 & Y & \\
\hline $10 / 4 / 201615: 15$ & 13.18 & 222.4 & 1.8 & Y & \\
\hline $10 / 5 / 20168: 55$ & 13.92 & 222.5 & 1.9 & Y & \\
\hline 10/6/2016 11:30 & 15.03 & 222.7 & 2.1 & Y & \\
\hline $10 / 12 / 201610: 30$ & 20.98 & 223.5 & 2.9 & Y & \\
\hline $10 / 17 / 201614: 30$ & 26.15 & 224.2 & 3.6 & Y & \\
\hline $10 / 18 / 201610: 00$ & 26.96 & 224.2 & 3.6 & Y & \\
\hline
\end{tabular}

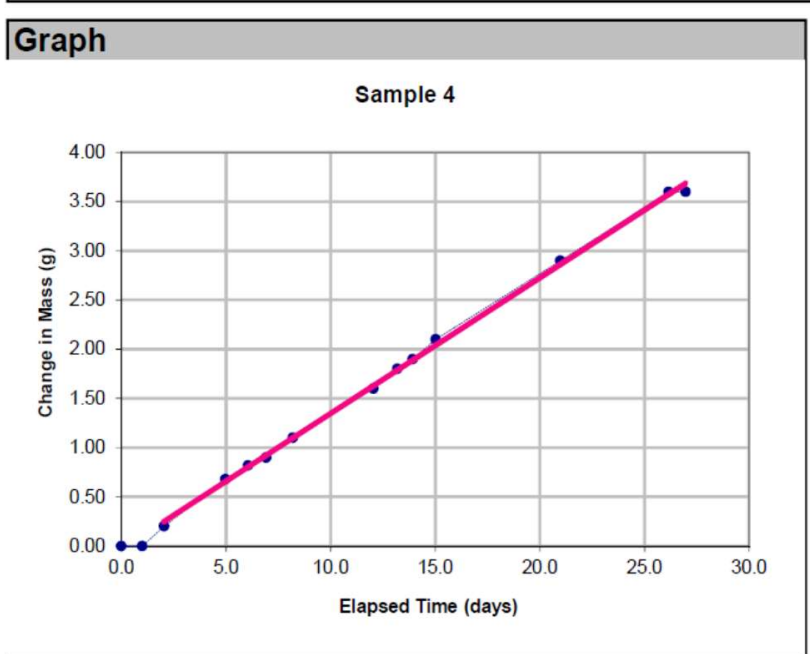

Testing Photo 
MRP Vapor Permeance Test

Material / Info

Method: Modified ASTM E96 Dry Cup

\begin{tabular}{|lll|l|}
\hline Material Description & & \\
& & & \\
Sample ID & 5 & & \\
Description & Cosella Dorken Nova Flexx & \\
Length & 0.153 & $(\mathrm{~m})$ & \\
Width & 0.145 & $(\mathrm{~m})$ & \\
Diameter & & $(\mathrm{m})$ & \\
Area & 0.0222 & $\left(\mathrm{~m}^{2}\right)$ & Exposed Area \\
Mass & & $(\mathrm{kg})$ & \\
Density & & $\left(\mathrm{kg} / \mathrm{m}^{3}\right)$ & \\
Sample Thickness & 0.001 & $(\mathrm{~m})$ & \\
Film Thickness & & $\begin{array}{l}\text { wet mils } \\
\left(\mathrm{m}^{3}\right)\end{array}$ & \\
Volume & & & \\
\hline
\end{tabular}

\begin{tabular}{|lcll|}
\hline Analysis Results & & & \\
& & & \\
Slope & 0.134 & $(\mathrm{~g} /$ day $)$ & Notes \\
Intercept & -0.0165 & & \\
$\mathrm{R}^{2}$ & 0.9983 & & \\
& & & \\
Cup Vp & 0 & $(\mathrm{~Pa}) \quad$ assumed \\
Room Vp & 1632 & $(\mathrm{~Pa}) \quad$ measured \\
delta Vp & -1632 & $(\mathrm{~Pa})$ & \\
& & & \\
Permeance $\left(\mathrm{M}_{\mathrm{T}}\right)$ & 42.8 & $\left(\mathrm{ng} / \mathrm{Pa} \cdot \mathrm{m}^{2} \cdot \mathrm{s}\right)$ \\
& 0.75 & US-perms \\
& 0.75 & US-perms (corrected) \\
\hline
\end{tabular}

\begin{tabular}{|c|c|c|c|c|c|}
\hline Data & & & & & using modified ASTM E96 \\
\hline Date and Time & $\begin{array}{c}\text { Elapsed } \\
\text { Time } \\
\text { (days) }\end{array}$ & $\begin{array}{c}\text { Measured } \\
\text { Mass } \\
\text { (grams) }\end{array}$ & $\begin{array}{c}\Delta \text { mass } \\
\text { (grams) }\end{array}$ & $\begin{array}{l}\text { Included in } \\
\text { Curve-fit }\end{array}$ & Remarks \\
\hline $9 / 21 / 201610: 53$ & 0.00 & 245.5 & 0.00 & Y & Start of Test \\
\hline $9 / 22 / 201610: 30$ & 0.98 & 245.6 & 0.10 & Y & \\
\hline $9 / 23 / 201611: 40$ & 2.03 & 245.7 & 0.20 & Y & \\
\hline 9/26/2016 10:00 & 4.96 & 246.21 & 0.71 & Y & \\
\hline $9 / 27 / 201612: 15$ & 6.06 & 246.38 & 0.88 & Y & \\
\hline $9 / 28 / 20169: 00$ & 6.92 & 246.4 & 0.90 & Y & \\
\hline $9 / 29 / 201615: 30$ & 8.19 & 246.6 & 1.10 & Y & \\
\hline $10 / 3 / 201612: 00$ & 12.05 & 247 & 1.50 & Y & \\
\hline $10 / 4 / 201615: 15$ & 13.18 & 247.2 & 1.7 & Y & \\
\hline 10/5/2016 8:55 & 13.92 & 247.3 & 1.8 & Y & \\
\hline 10/6/2016 11:30 & 15.03 & 247.54 & 2.0 & Y & \\
\hline $10 / 12 / 201610: 30$ & 20.98 & 248.3 & 2.8 & Y & \\
\hline $10 / 17 / 201614: 30$ & 26.15 & 249 & 3.5 & Y & \\
\hline $10 / 18 / 201610: 00$ & 26.96 & 249.1 & 3.6 & Y & \\
\hline
\end{tabular}
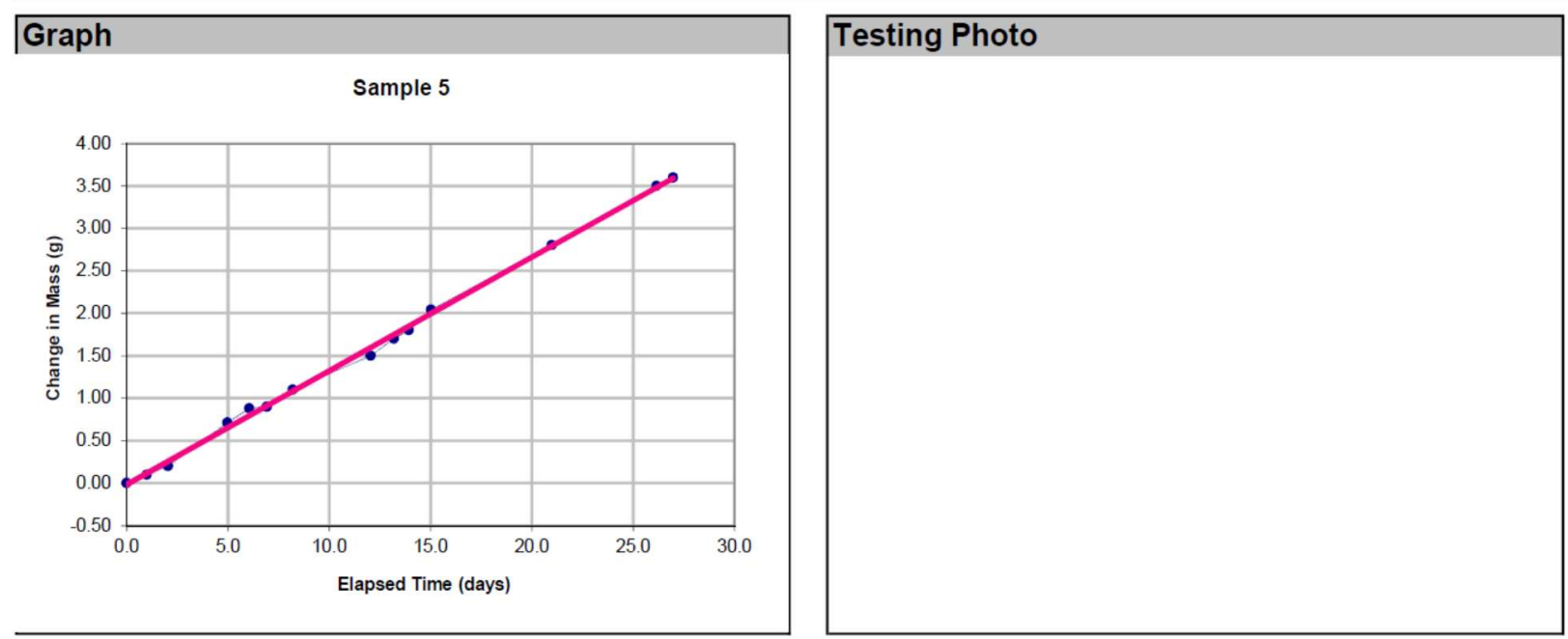
MRP Vapor Permeance Test

Material / Info

Method: Modified ASTM E96 Dry Cup

Data:

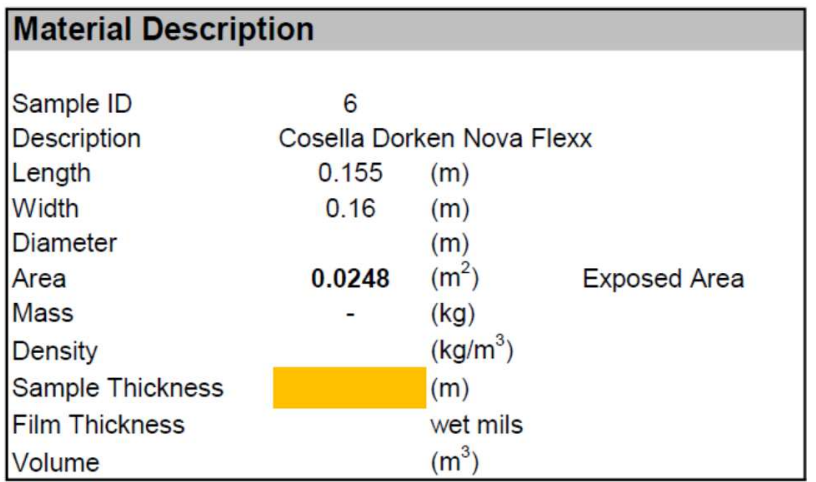

\begin{tabular}{|lcll|}
\hline Analysis Results & & & \\
& & & \\
Slope & -1.503 & $(\mathrm{~g} /$ day $)$ & Notes \\
Intercept & -0.0515 & & \\
$\mathrm{R}^{2}$ & 0.9999 & & \\
& & & \\
Cup Vp & 3263 & $(\mathrm{~Pa})$ & assumed \\
Room Vp & 1632 & $(\mathrm{~Pa}) \quad$ measured \\
delta Vp & 1632 & $(\mathrm{~Pa})$ & \\
& & & \\
Permeance $\left(\mathrm{M}_{\mathrm{T}}\right)$ & 430.0 & $\left(\mathrm{ng} / \mathrm{Pa} \cdot \mathrm{m}^{2} \cdot \mathrm{s}\right)$ \\
& 7.54 & $\mathrm{US}-$ perms \\
& 7.65 & US-perms (corrected) \\
\hline
\end{tabular}

\begin{tabular}{|c|c|c|c|c|c|}
\hline Data & & & & & using modified ASTM E96 \\
\hline Date and Time & $\begin{array}{c}\text { Elapsed } \\
\text { Time } \\
\text { (days) }\end{array}$ & $\begin{array}{c}\text { Measured } \\
\text { Mass } \\
\text { (grams) }\end{array}$ & $\begin{array}{c}\Delta \text { mass } \\
\text { (grams) }\end{array}$ & $\begin{array}{l}\text { Included in } \\
\text { Curve-fit }\end{array}$ & Remarks \\
\hline $9 / 21 / 201610: 53$ & 0.00 & 487.5 & 0.00 & Y & Start of Test \\
\hline $9 / 22 / 201610: 30$ & 0.98 & 486.1 & -1.40 & Y & \\
\hline $9 / 23 / 201611: 40$ & 2.03 & 484.4 & -3.10 & Y & \\
\hline $9 / 26 / 201610: 00$ & 4.96 & 480.1 & -7.40 & $Y$ & \\
\hline $9 / 27 / 201612: 15$ & 6.06 & 478.4 & -9.1 & Y & \\
\hline $9 / 28 / 20169: 00$ & 6.92 & 477 & -10.5 & Y & \\
\hline $9 / 29 / 201615: 30$ & 8.19 & 475.1 & -12.4 & Y & \\
\hline $10 / 3 / 201612: 00$ & 12.05 & 469.2 & -18.3 & Y & \\
\hline $10 / 4 / 201615: 15$ & 13.18 & 467.5 & -20.0 & Y & \\
\hline $10 / 5 / 20168: 55$ & 13.92 & 466.4 & -21.1 & Y & \\
\hline $10 / 6 / 201611: 30$ & 15.03 & 464.7 & -22.8 & Y & \\
\hline $10 / 12 / 201610: 30$ & 20.98 & 455.9 & -31.6 & $Y$ & \\
\hline $10 / 17 / 201614: 30$ & 26.15 & 448.2 & -39.3 & Y & \\
\hline $10 / 18 / 201610: 00$ & 26.96 & 447.1 & -40.4 & Y & \\
\hline
\end{tabular}

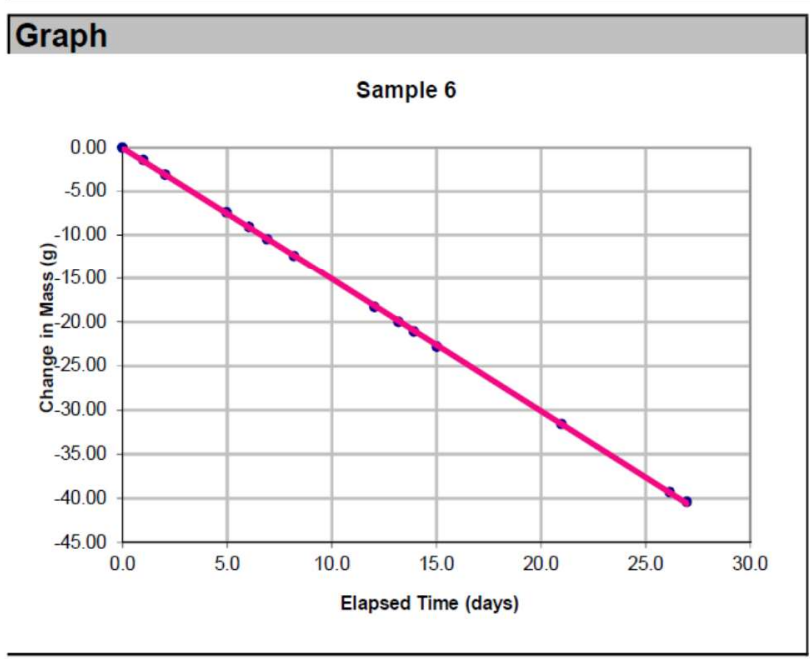

Testing Photo 
MRP Vapor Permeance Test

Material / Info

Method: Modified ASTM E96 Dry Cup

Data:

\begin{tabular}{|lcll|}
\hline \multicolumn{3}{ll|}{ Material Description } \\
Sample ID & \multicolumn{3}{l|}{} \\
Description & \multicolumn{2}{l|}{ Cosella Dorken Nova Flexx } \\
Length & 0.155 & $(\mathrm{~m})$ & \\
Width & 0.158 & $(\mathrm{~m})$ & \\
Diameter & & $(\mathrm{m})$ & \\
Area & 0.0245 & $\left(\mathrm{~m}^{2}\right)$ & Exposed Area \\
Mass & - & $(\mathrm{kg})$ & \\
Density & & $\left(\mathrm{kg} / \mathrm{m}^{3}\right)$ & \\
Sample Thickness & & $(\mathrm{m})$ & \\
Film Thickness & & wet mils & \\
Volume & & $\left(\mathrm{m}^{3}\right)$ & \\
\hline
\end{tabular}

\begin{tabular}{|lcll|}
\hline Analysis Results & & & \\
Slope & -1.500 & $(\mathrm{~g} /$ day $)$ & Notes \\
Intercept & 0.0761 & & \\
$\mathrm{R}^{2}$ & 0.9999 & & \\
& & & \\
Cup Vp & 3263 & $(\mathrm{~Pa})$ & assumed \\
Room Vp & 1632 & $(\mathrm{~Pa})$ & measured \\
delta Vp & 1632 & $(\mathrm{~Pa})$ & \\
& & & \\
Permeance $\left(\mathrm{M}_{\mathrm{T}}\right)$ & 434.4 & $\left(\mathrm{ng} / \mathrm{Pa} \cdot \mathrm{m}^{2} \cdot \mathrm{s}\right)$ \\
& 7.62 & US-perms \\
& 7.74 & US-perms (corrected) \\
\hline
\end{tabular}

\begin{tabular}{|c|c|c|c|c|c|}
\hline Data & & & & & using modified ASTM E96 \\
\hline Date and Time & $\begin{array}{c}\text { Elapsed } \\
\text { Time } \\
\text { (days) }\end{array}$ & $\begin{array}{l}\text { Measured } \\
\text { Mass } \\
\text { (grams) }\end{array}$ & $\begin{array}{c}\Delta \text { mass } \\
\text { (grams) }\end{array}$ & $\begin{array}{l}\text { Included in } \\
\text { Curve-fit }\end{array}$ & Remarks \\
\hline $9 / 21 / 201610: 53$ & 0.00 & 463.9 & 0.00 & Y & Start of Test \\
\hline $9 / 22 / 201610: 30$ & 0.98 & 462.6 & -1.30 & Y & \\
\hline $9 / 23 / 201611: 40$ & 2.03 & 461 & -2.90 & Y & \\
\hline $9 / 26 / 201610: 00$ & 4.96 & 456.6 & -7.30 & Y & \\
\hline $9 / 27 / 201612: 15$ & 6.06 & 455 & -8.9 & Y & \\
\hline $9 / 28 / 20169: 00$ & 6.92 & 453.6 & -10.3 & Y & \\
\hline $9 / 29 / 201615: 30$ & 8.19 & 451.7 & -12.2 & Y & \\
\hline $10 / 3 / 201612: 00$ & 12.05 & 445.8 & -18.1 & Y & \\
\hline $10 / 4 / 201615: 15$ & 13.18 & 444.1 & -19.8 & Y & \\
\hline $10 / 5 / 20168: 55$ & 13.92 & 443 & -20.9 & Y & \\
\hline 10/6/2016 11:30 & 15.03 & 441.3 & -22.6 & Y & \\
\hline $10 / 12 / 201610: 30$ & 20.98 & 432.5 & -31.4 & Y & \\
\hline $10 / 17 / 201614: 30$ & 26.15 & 424.8 & -39.1 & Y & \\
\hline $10 / 18 / 201610: 00$ & 26.96 & 423.7 & -40.2 & Y & \\
\hline
\end{tabular}

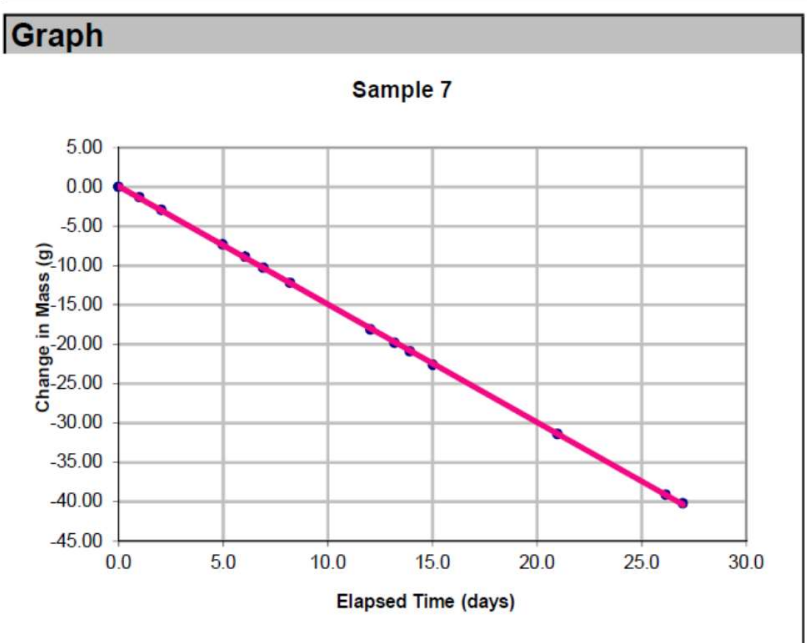

\begin{tabular}{|l|}
\hline Testing Photo \\
\hline
\end{tabular} 
MRP Vapor Permeance Test

Material / Info

Method: Modified ASTM E96 Dry Cup

Data:

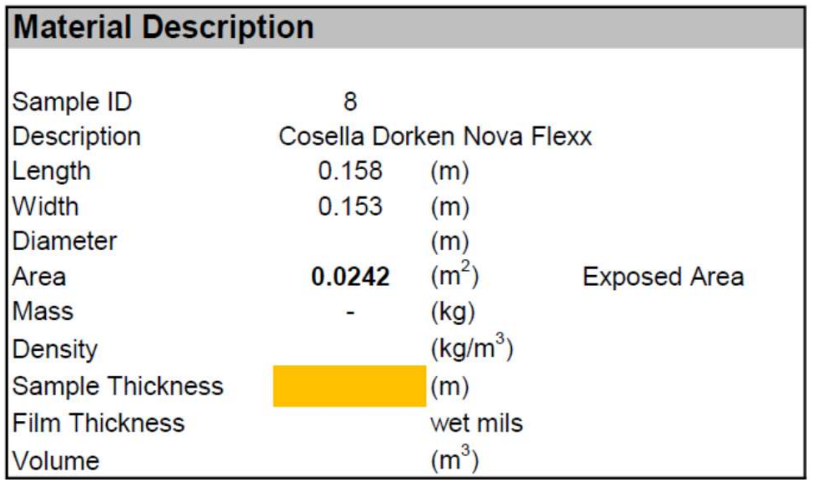

\begin{tabular}{|lcll|}
\hline Analysis Results & & & \\
& & & \\
Slope & -1.548 & $(\mathrm{~g} /$ day $)$ & Notes \\
Intercept & -0.0029 & & \\
$\mathrm{R}^{2}$ & 0.9999 & & \\
& & & \\
Cup Vp & 3263 & $(\mathrm{~Pa})$ & assumed \\
Room Vp & 1632 & $(\mathrm{~Pa}) \quad$ measured \\
delta Vp & 1632 & $(\mathrm{~Pa})$ & \\
& & & \\
Permeance $\left(\mathrm{M}_{\mathrm{T}}\right)$ & 454.2 & $\left(\mathrm{ng} / \mathrm{Pa} \cdot \mathrm{m}^{2} \cdot \mathrm{s}\right)$ \\
& 7.97 & US-perms \\
& 8.11 & US-perms (corrected) \\
\hline
\end{tabular}

\begin{tabular}{|c|c|c|c|c|c|}
\hline Data & & & & & using modified ASTM E96 \\
\hline Date and Time & $\begin{array}{l}\text { Elapsed } \\
\text { Time } \\
\text { (days) }\end{array}$ & $\begin{array}{l}\text { Measured } \\
\text { Mass } \\
\text { (grams) }\end{array}$ & $\begin{array}{c}\Delta \text { mass } \\
\text { (grams) }\end{array}$ & $\begin{array}{l}\text { Included in } \\
\text { Curve-fit }\end{array}$ & Remarks \\
\hline $9 / 21 / 201610: 53$ & 0.00 & 487.5 & 0.00 & Y & Start of Test \\
\hline $9 / 22 / 201610: 30$ & 0.98 & 486.1 & -1.40 & Y & \\
\hline $9 / 23 / 201611: 40$ & 2.03 & 484.5 & -3.00 & Y & \\
\hline $9 / 26 / 201610: 00$ & 4.96 & 479.9 & -7.60 & $Y$ & \\
\hline $9 / 27 / 201612: 15$ & 6.06 & 478.2 & -9.3 & Y & \\
\hline $9 / 28 / 20169: 00$ & 6.92 & 476.7 & -10.8 & Y & \\
\hline $9 / 29 / 201615: 30$ & 8.19 & 474.8 & -12.7 & Y & \\
\hline $10 / 3 / 201612: 00$ & 12.05 & 468.7 & -18.8 & Y & \\
\hline $10 / 4 / 201615: 15$ & 13.18 & 466.9 & -20.6 & Y & \\
\hline $10 / 5 / 20168: 55$ & 13.92 & 465.8 & -21.7 & Y & \\
\hline 10/6/2016 11:30 & 15.03 & 464.1 & -23.4 & Y & \\
\hline $10 / 12 / 201610: 30$ & 20.98 & 455 & -32.5 & $Y$ & \\
\hline $10 / 17 / 201614: 30$ & 26.15 & 447.2 & -40.3 & Y & \\
\hline $10 / 18 / 201610: 00$ & 26.96 & 445.9 & -41.6 & $Y$ & \\
\hline
\end{tabular}

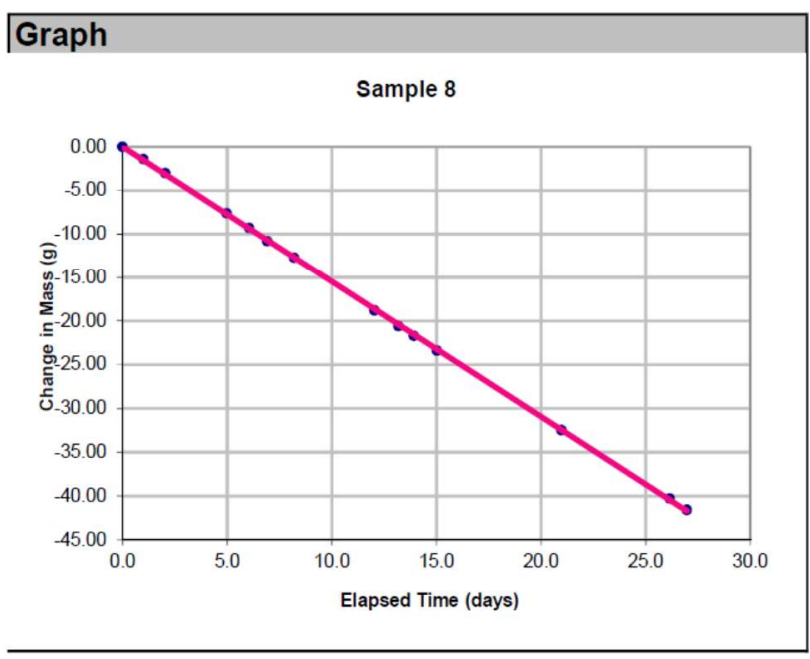

Testing Photo 
MRP Vapor Permeance Test

Material / Info

Method: Modified ASTM E96 Dry Cup

Data:

\begin{tabular}{|c|c|c|c|}
\hline \multicolumn{4}{|c|}{ Material Description } \\
\hline Sample ID & \multicolumn{3}{|l|}{9} \\
\hline Description & \multicolumn{3}{|c|}{ Cosella Dorken Nova Flexx } \\
\hline Length & 0.156 & $(\mathrm{~m})$ & \\
\hline Width & 0.152 & $(\mathrm{~m})$ & \\
\hline Diameter & & $(\mathrm{m})$ & \\
\hline Area & 0.0237 & $\left(\mathrm{~m}^{2}\right)$ & Exposed Area \\
\hline Mass & - & $(\mathrm{kg})$ & \\
\hline Density & & $\left(\mathrm{kg} / \mathrm{m}^{3}\right)$ & \\
\hline Sample Thickness & & $(\mathrm{m})$ & \\
\hline Film Thickness & & wet mil & \\
\hline Volume & & $\left(\mathrm{m}^{3}\right)$ & \\
\hline
\end{tabular}

\begin{tabular}{|lcll|}
\hline Analysis Results & & & \\
& & & \\
Slope & -1.554 & $(\mathrm{~g} /$ day $)$ & Notes \\
Intercept & -0.1462 & & \\
$R^{2}$ & 0.9998 & & \\
& & & \\
Cup Vp & 3263 & $(\mathrm{~Pa})$ & assumed \\
Room Vp & 1632 & $(\mathrm{~Pa}) \quad$ measured \\
delta Vp & 1632 & $(\mathrm{~Pa})$ & \\
& & & \\
Permeance $\left(\mathrm{M}_{\mathrm{T}}\right)$ & 464.9 & $\left(\mathrm{ng} / \mathrm{Pa}^{2} \mathrm{~m}^{2} \cdot \mathrm{s}\right)$ \\
& 8.16 & $\mathrm{US}-$ perms \\
& 8.32 & US-perms (corrected) \\
\hline
\end{tabular}

\begin{tabular}{|c|c|c|c|c|c|}
\hline Data & & & & & using modified ASTM E96 \\
\hline Date and Time & $\begin{array}{l}\text { Elapsed } \\
\text { Time } \\
\text { (days) }\end{array}$ & $\begin{array}{l}\text { Measured } \\
\text { Mass } \\
\text { (grams) }\end{array}$ & $\begin{array}{c}\Delta \text { mass } \\
\text { (grams) }\end{array}$ & $\begin{array}{l}\text { Included in } \\
\text { Curve-fit }\end{array}$ & Remarks \\
\hline $9 / 21 / 2016$ 10:53 & 0.00 & 489.1 & 0.00 & Y & Start of Test \\
\hline $9 / 22 / 201610: 30$ & 0.98 & 487.7 & -1.40 & Y & \\
\hline $9 / 23 / 201611: 40$ & 2.03 & 486 & -3.10 & Y & \\
\hline $9 / 26 / 201610: 00$ & 4.96 & 481.3 & -7.80 & Y & \\
\hline $9 / 27 / 201612: 15$ & 6.06 & 479.5 & -9.6 & Y & \\
\hline 9/28/2016 9:00 & 6.92 & 478.1 & -11.0 & Y & \\
\hline 9/29/2016 15:30 & 8.19 & 476 & -13.1 & Y & \\
\hline $10 / 3 / 201612: 00$ & 12.05 & 470 & -19.1 & Y & \\
\hline $10 / 4 / 201615: 15$ & 13.18 & 468.2 & -20.9 & Y & \\
\hline 10/5/2016 8:55 & 13.92 & 467.2 & -21.9 & Y & \\
\hline $10 / 6 / 201611: 30$ & 15.03 & 465.4 & -23.7 & Y & \\
\hline $10 / 12 / 201610: 30$ & 20.98 & 456.4 & -32.7 & Y & \\
\hline $10 / 17 / 201614: 30$ & 26.15 & 448.6 & -40.5 & Y & \\
\hline $10 / 18 / 201610: 00$ & 26.96 & 447.2 & -41.9 & Y & \\
\hline
\end{tabular}

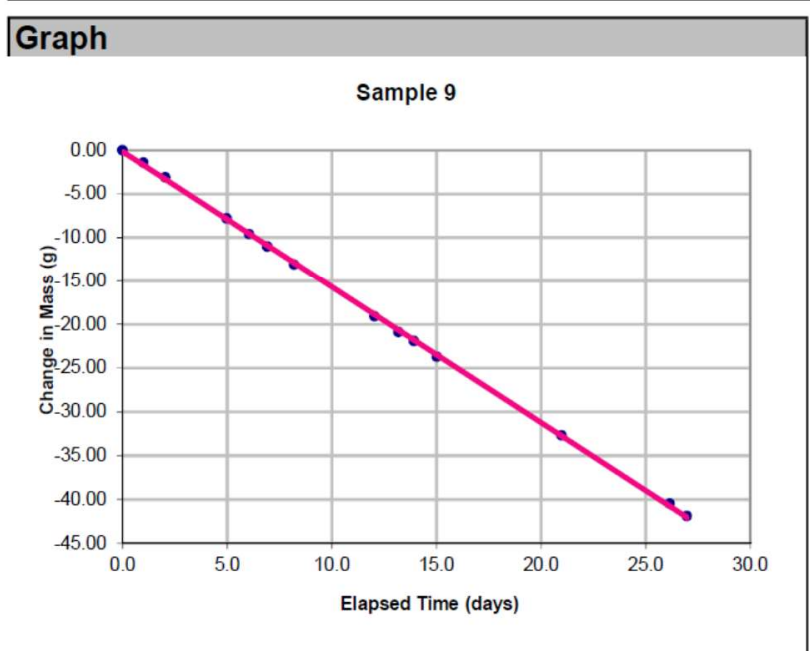

Testing Photo 
MRP Vapor Permeance Test

Material / Info

\begin{tabular}{|c|c|c|c|}
\hline \\
\hline \multicolumn{4}{|c|}{$\begin{array}{l}\text { Material Description } \\
\text { Sample ID }\end{array}$} \\
\hline \multirow{3}{*}{$\begin{array}{l}\text { Description } \\
\text { Length } \\
\text { Width }\end{array}$} & \multicolumn{3}{|c|}{ Cosella Dorken Nova Flexx } \\
\hline & \multirow{2}{*}{0.155} & \multicolumn{2}{|l|}{$(\mathrm{m})$} \\
\hline & & (m) & \\
\hline \multicolumn{4}{|l|}{ Diameter } \\
\hline Area & 0.0237 & $\left(\mathrm{~m}^{2}\right)$ & \multirow[t]{2}{*}{ Exposed Area } \\
\hline Mass & - & $(\mathrm{kg})$ & \\
\hline \multicolumn{2}{|l|}{ Density } & $\left(\mathrm{kg} / \mathrm{m}^{3}\right.$ & \\
\hline \multicolumn{2}{|l|}{ Sample Thickness } & $(\mathrm{m})$ & \\
\hline $\begin{array}{l}\text { Film Thickness } \\
\text { Volume }\end{array}$ & \multicolumn{3}{|c|}{ wet mils } \\
\hline
\end{tabular}

\begin{tabular}{|c|c|c|c|}
\hline \multicolumn{4}{|c|}{ Analysis Results } \\
\hline $\begin{array}{l}\text { Slope } \\
\text { Intercept } \\
\mathrm{R}^{2}\end{array}$ & $\begin{array}{l}-1.523 \\
0.0302 \\
1.0000\end{array}$ & (g/day) & Notes \\
\hline $\begin{array}{l}\text { Cup Vp } \\
\text { Room Vp } \\
\text { delta Vp }\end{array}$ & $\begin{array}{l}3263 \\
1632 \\
1632\end{array}$ & $\begin{array}{l}(\mathrm{Pa}) \\
(\mathrm{Pa}) \\
(\mathrm{Pa})\end{array}$ & $\begin{array}{l}\text { assumed } \\
\text { measured }\end{array}$ \\
\hline Permeance $\left(\mathrm{M}_{\mathrm{T}}\right)$ & $\begin{array}{c}455.7 \\
7.99 \\
8.14 \\
\end{array}$ & $\begin{array}{l}\text { (ng/Pa.I } \\
\text { US-perr } \\
\text { US-perr }\end{array}$ & corrected) \\
\hline
\end{tabular}

\begin{tabular}{|c|c|c|c|c|c|}
\hline Data & & & & & using modified ASTM E96 \\
\hline Date and Time & $\begin{array}{l}\text { Elapsed } \\
\text { Time } \\
\text { (days) }\end{array}$ & $\begin{array}{l}\text { Measured } \\
\text { Mass } \\
\text { (grams) }\end{array}$ & $\begin{array}{c}\Delta \text { mass } \\
\text { (grams) }\end{array}$ & $\begin{array}{l}\text { Included in } \\
\text { Curve-fit }\end{array}$ & Remarks \\
\hline $9 / 21 / 201610: 53$ & 0.00 & 460.5 & 0.00 & Y & Start of Test \\
\hline 9/22/2016 10:30 & 0.98 & 459 & -1.50 & Y & \\
\hline $9 / 23 / 201611: 40$ & 2.03 & 457.6 & -2.90 & Y & \\
\hline $9 / 26 / 201610: 00$ & 4.96 & 453 & -7.50 & Y & \\
\hline $9 / 27 / 201612: 15$ & 6.06 & 451.3 & -9.2 & Y & \\
\hline 9/28/2016 9:00 & 6.92 & 449.9 & -10.6 & Y & \\
\hline $9 / 29 / 201615: 30$ & 8.19 & 448 & -12.5 & Y & \\
\hline $10 / 3 / 201612: 00$ & 12.05 & 442.1 & -18.4 & Y & \\
\hline $10 / 4 / 201615: 15$ & 13.18 & 440.4 & -20.1 & Y & \\
\hline $10 / 5 / 20168: 55$ & 13.92 & 439.4 & -21.1 & Y & \\
\hline 10/6/2016 11:30 & 15.03 & 437.6 & -22.9 & Y & \\
\hline $10 / 12 / 201610: 30$ & 20.98 & 428.7 & -31.8 & Y & \\
\hline $10 / 17 / 201614: 30$ & 26.15 & 420.7 & -39.8 & Y & \\
\hline $10 / 18 / 201610: 00$ & 26.96 & 419.4 & -41.1 & Y & \\
\hline
\end{tabular}
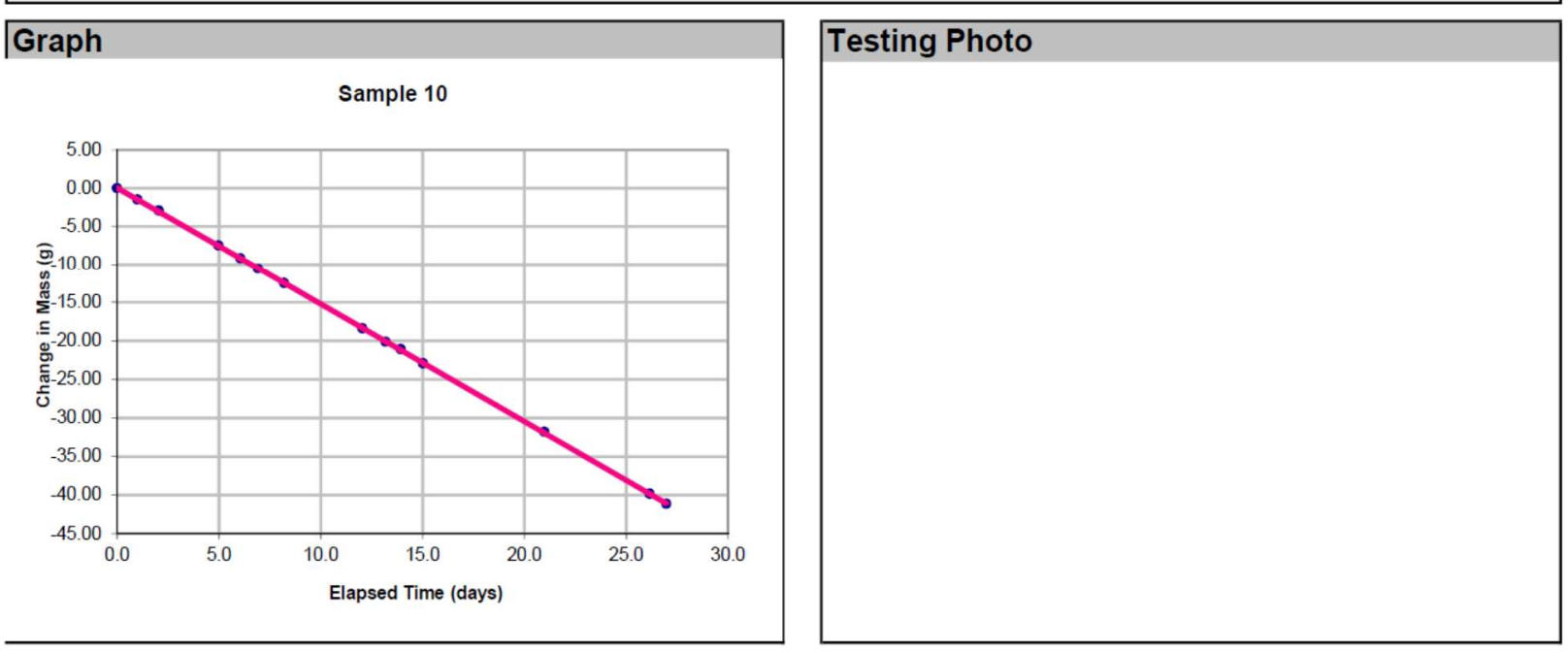
MRP Vapor Permeance Test

Material / Info

Method: Modified ASTM E96 Wet Cup

Data:

\begin{tabular}{|c|c|c|c|}
\hline \multicolumn{4}{|c|}{ Material Description } \\
\hline Sample ID & \multicolumn{3}{|l|}{ High RH 1} \\
\hline Description & \multicolumn{3}{|c|}{ Cosella Dorken Nova Flexx } \\
\hline Length & 0.155 & $(\mathrm{~m})$ & \\
\hline Width & 0.155 & $(\mathrm{~m})$ & \\
\hline Diameter & & (m) & \\
\hline Area & 0.0240 & $\left(m^{2}\right)$ & Exposed Area \\
\hline Mass & - & $(\mathrm{kg})$ & \\
\hline Density & & $\left(\mathrm{kg} / \mathrm{m}^{3}\right.$ & \\
\hline Sample Thickness & & $(\mathrm{m})$ & \\
\hline $\begin{array}{l}\text { Film Thickness } \\
\text { Volume }\end{array}$ & & $\begin{array}{l}\text { wet } \mathrm{mi} \\
\left(\mathrm{m}^{3}\right)\end{array}$ & \\
\hline
\end{tabular}

\begin{tabular}{|lcll|}
\hline Analysis Results & & & \\
Slope & & & \\
Intercept & -1.748 & $(\mathrm{~g} / \mathrm{d}$ day $)$ & Notes \\
$\mathrm{R}^{2}$ & 0.0554 & & \\
& 0.9994 & & \\
Cup Vp & & & \\
Room Vp & 3263 & $(\mathrm{~Pa})$ & assumed \\
delta Vp & 1632 & $(\mathrm{~Pa})$ & measured \\
& 1632 & $(\mathrm{~Pa})$ & \\
Permeance $\left(\mathrm{M}_{\mathrm{T}}\right)$ & 516.3 & $\left(\mathrm{ng} / \mathrm{Pa} \cdot \mathrm{m}^{2} \cdot \mathrm{s}\right)$ \\
& 9.06 & US-perms & \\
& 9.31 & US-perms (corrected) \\
\hline
\end{tabular}

\begin{tabular}{|c|c|c|c|c|c|}
\hline Data & & & & & using mo \\
\hline Date and Time & $\begin{array}{c}\text { Elapsed } \\
\text { Time } \\
\text { (days) }\end{array}$ & $\begin{array}{c}\text { Measured } \\
\text { Mass } \\
\text { (grams) }\end{array}$ & $\begin{array}{c}\Delta \text { mass } \\
\text { (grams) }\end{array}$ & $\begin{array}{l}\text { Included in } \\
\text { Curve-fit }\end{array}$ & Remarks \\
\hline 11/1/2016 10:15 & 0.00 & 442 & 0.00 & Y & Start of Test \\
\hline $11 / 2 / 201614: 22$ & 1.17 & 440.3 & -1.70 & Y & \\
\hline $11 / 3 / 201612: 40$ & 2.10 & 438.5 & -3.50 & Y & \\
\hline $11 / 4 / 201616: 00$ & 3.24 & 436.1 & -5.90 & Y & \\
\hline $11 / 7 / 201613: 00$ & 6.11 & 431.2 & -10.8 & Y & \\
\hline $11 / 9 / 20169: 00$ & 7.95 & 428.3 & -13.7 & Y & \\
\hline $11 / 10 / 201615: 25$ & 9.22 & 425.8 & -16.2 & Y & \\
\hline $11 / 11 / 201614: 20$ & 10.17 & 424.2 & -17.8 & Y & \\
\hline $11 / 14 / 201613: 00$ & 13.11 & 419.3 & -22.7 & $Y$ & \\
\hline
\end{tabular}
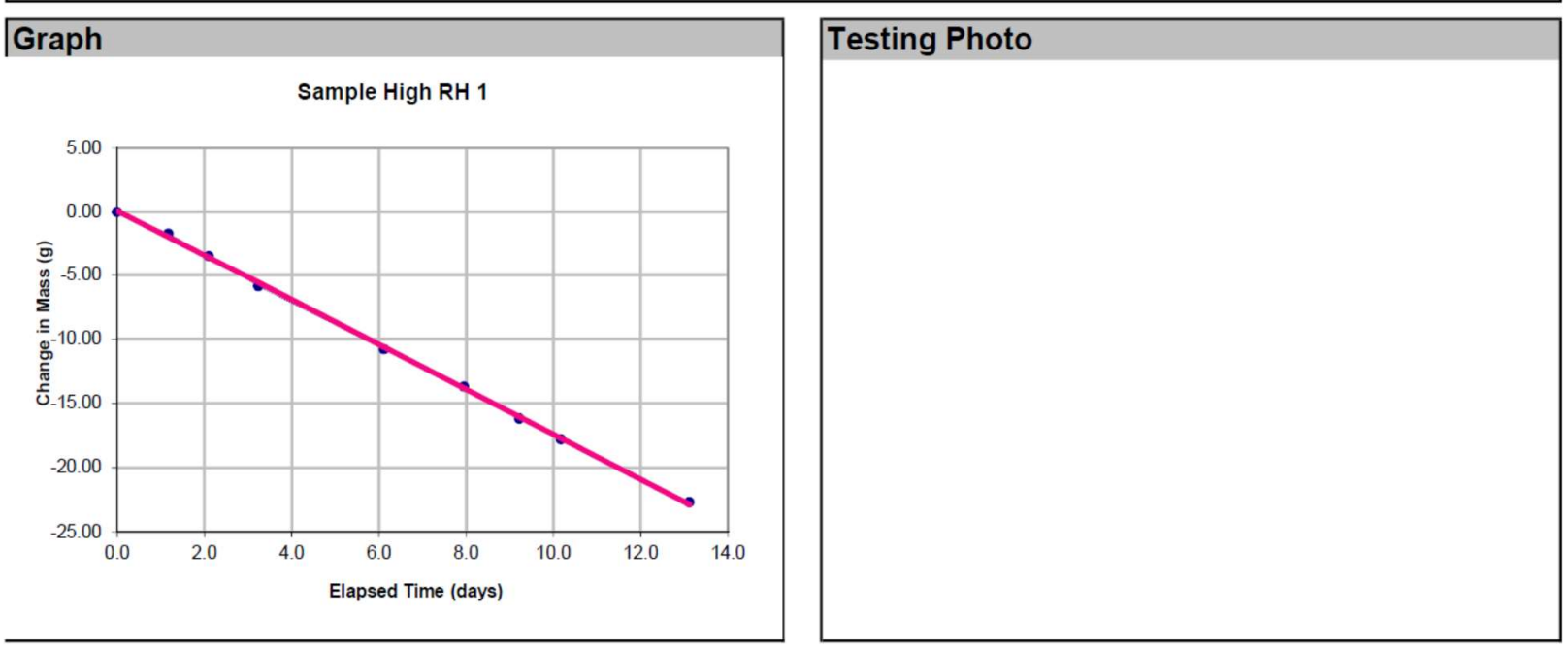
MRP Vapor Permeance Test

Material / Info

Method: Modified ASTM E96 Wet Cup

Data:

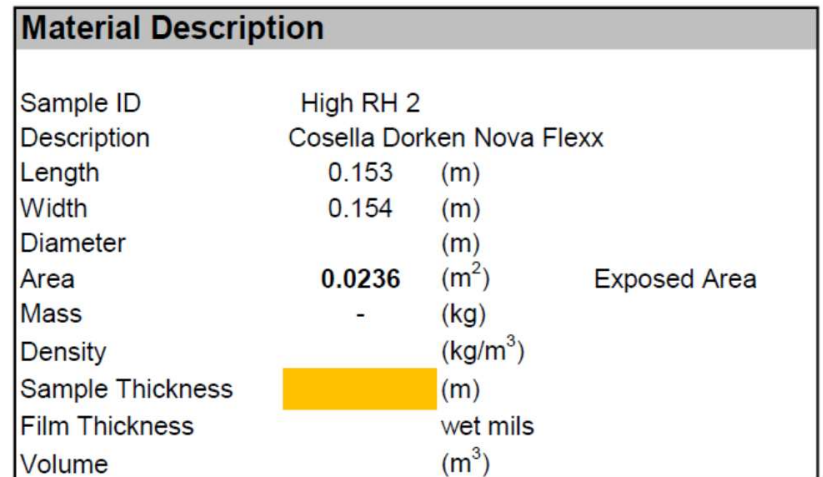

\begin{tabular}{|lcll|}
\hline Analysis Results & & & \\
Slope & -1.664 & $(\mathrm{~g} /$ day $)$ & Notes \\
Intercept & 0.0555 & & \\
$R^{2}$ & 0.9994 & & \\
& & & \\
Cup Vp & 3263 & $(\mathrm{~Pa})$ & assumed \\
Room Vp & 1632 & $(\mathrm{~Pa})$ & measured \\
delta Vp & 1632 & $(\mathrm{~Pa})$ & \\
& & & \\
Permeance $\left(\mathrm{M}_{\mathrm{T}}\right)$ & 500.9 & $\left(\mathrm{ng} / \mathrm{Pa} \cdot \mathrm{m}^{2} \cdot \mathrm{s}\right)$ \\
& $\mathbf{8 . 7 9}$ & $\mathrm{US}-\mathrm{perms}$ \\
& 9.04 & US-perms (corrected) \\
\hline
\end{tabular}

\begin{tabular}{|c|c|c|c|c|c|}
\hline Data & & & & & using mo \\
\hline Date and Time & $\begin{array}{c}\text { Elapsed } \\
\text { Time } \\
\text { (days) }\end{array}$ & $\begin{array}{l}\text { Measured } \\
\text { Mass } \\
\text { (grams) }\end{array}$ & $\begin{array}{c}\Delta \text { mass } \\
\text { (grams) }\end{array}$ & $\begin{array}{l}\text { Included in } \\
\text { Curve-fit }\end{array}$ & Remarks \\
\hline 11/1/2016 10:15 & 0.00 & 438.1 & 0.00 & Y & Start of Test \\
\hline $11 / 2 / 201614: 22$ & 1.17 & 436.3 & -1.80 & Y & \\
\hline $11 / 3 / 201612: 40$ & 2.10 & 434.5 & -3.60 & Y & \\
\hline 11/4/2016 16:00 & 3.24 & 432.7 & -5.40 & Y & \\
\hline $11 / 7 / 201613: 00$ & 6.11 & 428 & -10.1 & Y & \\
\hline 11/9/2016 9:00 & 7.95 & 425 & -13.1 & Y & \\
\hline $11 / 10 / 201615: 25$ & 9.22 & 423.1 & -15.0 & Y & \\
\hline $11 / 11 / 201614: 20$ & 10.17 & 421.4 & -16.7 & Y & \\
\hline $11 / 14 / 201613: 00$ & 13.11 & 416 & -22.1 & Y & \\
\hline
\end{tabular}

\section{Graph}

Sample High RH 2

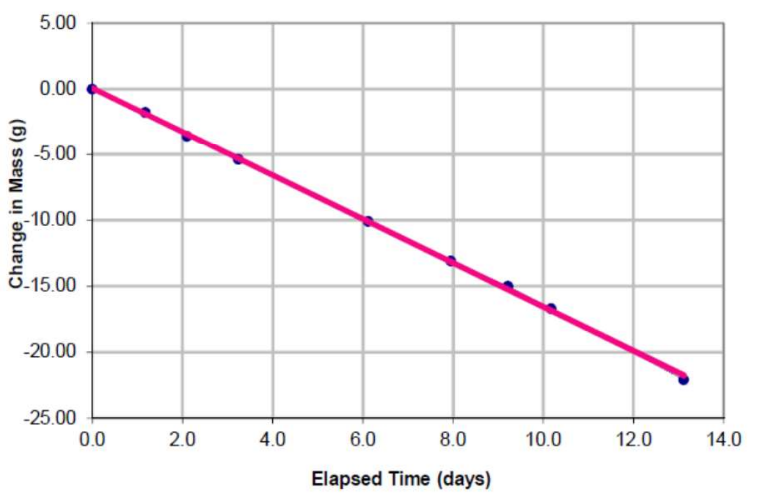

Testing Photo 
MRP Vapor Permeance Test

Material / Info

Method: Modified ASTM E96 Wet Cup

\begin{tabular}{|lcll|}
\hline \multicolumn{3}{|l|}{ Material Description } \\
Sample ID & High RH 3 & \\
Description & \multicolumn{2}{l|}{ Cosella Dorken Nova Flexx } & \\
Length & 0.153 & $(\mathrm{~m})$ & \\
Width & 0.153 & $(\mathrm{~m})$ & \\
Diameter & & $(\mathrm{m})$ & \\
Area & 0.0234 & $\left(\mathrm{~m}^{2}\right)$ & Exposed Area \\
Mass & - & $(\mathrm{kg})$ & \\
Density & & $\left(\mathrm{kg} / \mathrm{m}^{3}\right)$ & \\
Sample Thickness & & $(\mathrm{m})$ & \\
Film Thickness & & wet mils & \\
Volume & & $\left(\mathrm{m}^{3}\right)$ & \\
\hline
\end{tabular}

\begin{tabular}{|lcll|}
\hline Analysis Results & & & \\
Slope & -1.745 & $(\mathrm{~g} /$ day $)$ & Notes \\
Intercept & 0.0705 & & \\
$\mathrm{R}^{2}$ & 0.9989 & & \\
& & & \\
Cup Vp & 3263 & $(\mathrm{~Pa})$ & assumed \\
Room Vp & 1632 & $(\mathrm{~Pa})$ & measured \\
delta Vp & 1632 & $(\mathrm{~Pa})$ & \\
& & & \\
Permeance $\left(\mathrm{M}_{\mathrm{T}}\right)$ & 528.9 & $\left(\mathrm{ng} / \mathrm{Pa} \cdot \mathrm{m}^{2} \cdot \mathrm{s}\right)$ \\
& 9.28 & US-perms \\
& 9.59 & US-perms (corrected) \\
\hline
\end{tabular}

\begin{tabular}{|c|c|c|c|c|c|}
\hline Data & & & & & using modified ASTM E96 \\
\hline Date and Time & $\begin{array}{l}\text { Elapsed } \\
\text { Time } \\
\text { (days) }\end{array}$ & $\begin{array}{l}\text { Measured } \\
\text { Mass } \\
\text { (grams) }\end{array}$ & $\begin{array}{c}\Delta \text { mass } \\
\text { (grams) }\end{array}$ & $\begin{array}{l}\text { Included in } \\
\text { Curve-fit }\end{array}$ & Remarks \\
\hline $11 / 1 / 201610: 15$ & 0.00 & 441.1 & 0.00 & Y & Start of Test \\
\hline $11 / 2 / 201614: 22$ & 1.17 & 439.3 & -1.80 & Y & \\
\hline $11 / 3 / 201612: 40$ & 2.10 & 437.7 & -3.40 & Y & \\
\hline $11 / 4 / 201616: 00$ & 3.24 & 435.7 & -5.40 & Y & \\
\hline 11/7/2016 13:00 & 6.11 & 430 & -11.1 & Y & \\
\hline 11/9/2016 9:00 & 7.95 & 427 & -14.1 & Y & \\
\hline $11 / 10 / 201615: 25$ & 9.22 & 425 & -16.1 & Y & \\
\hline $11 / 11 / 201614: 20$ & 10.17 & 423.5 & -17.6 & Y & \\
\hline $11 / 14 / 201613: 00$ & 13.11 & 418.6 & -22.5 & Y & \\
\hline
\end{tabular}
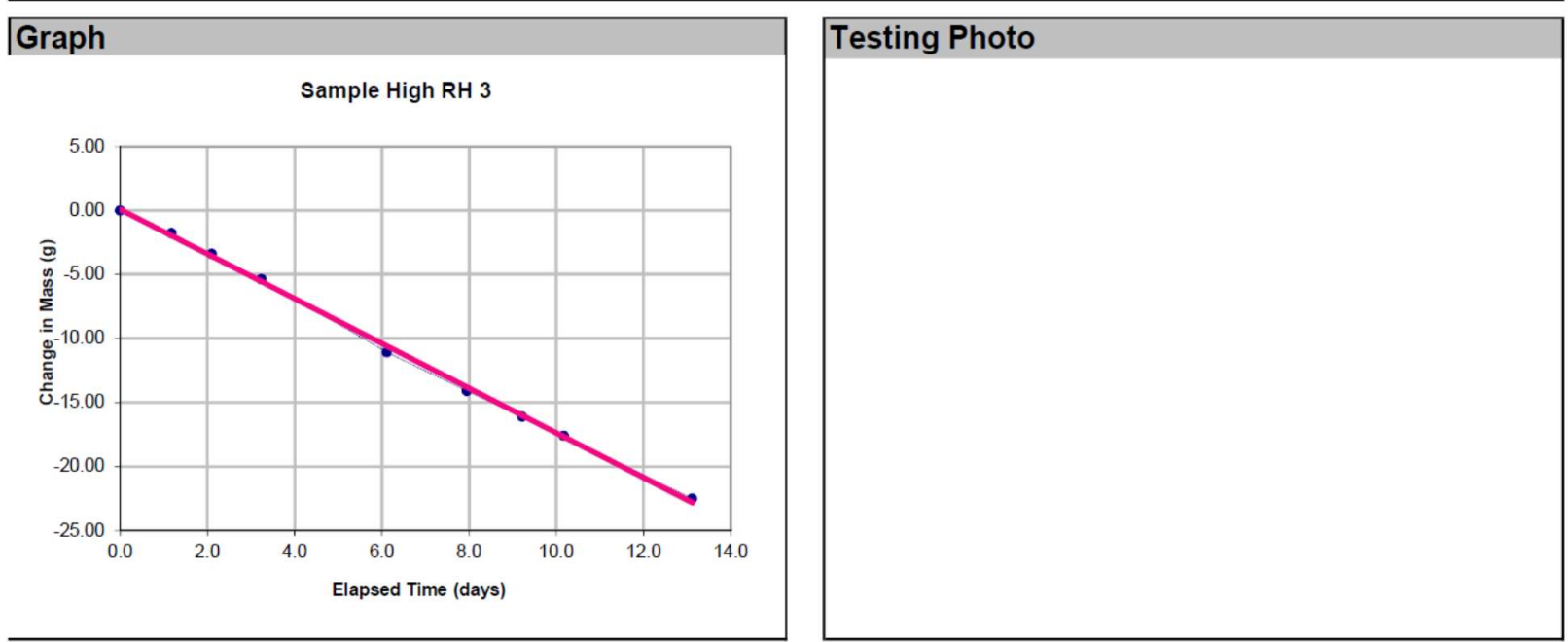
MRP Vapor Permeance Test

Material / Info

Method: Modified ASTM E96 Wet Cup

\begin{tabular}{|c|c|c|c|}
\hline \multicolumn{4}{|c|}{ Material Description } \\
\hline Sample ID & \multicolumn{3}{|l|}{ High RH 4} \\
\hline Description & \multicolumn{3}{|c|}{ Cosella Dorken Nova Flexx } \\
\hline Length & 0.153 & $(\mathrm{~m})$ & \\
\hline Width & 0.154 & (m) & \\
\hline Diameter & & (m) & \\
\hline Area & 0.0236 & $\left(m^{2}\right)$ & Exposed Area \\
\hline Mass & - & $(\mathrm{kg})$ & \\
\hline Density & & $\left(\mathrm{kg} / \mathrm{m}^{3}\right.$ & \\
\hline Sample Thickness & & (m) & \\
\hline $\begin{array}{l}\text { Film Thickness } \\
\text { Volume }\end{array}$ & & $\begin{array}{l}\text { wet mi } \\
\left(\mathrm{m}^{3}\right)\end{array}$ & \\
\hline
\end{tabular}

\begin{tabular}{|lcll|}
\hline Analysis Results & & & \\
Slope & & & \\
Intercept & -1.771 & $(\mathrm{~g} /$ day $)$ & Notes \\
$\mathrm{R}^{2}$ & 0.1094 & & \\
& 0.9998 & & \\
Cup Vp & 3263 & $(\mathrm{~Pa})$ & assumed \\
Room Vp & 1632 & $(\mathrm{~Pa}) \quad$ measured \\
delta Vp & 1632 & $(\mathrm{~Pa})$ & \\
& & & \\
Permeance $\left(\mathrm{M}_{\mathrm{T}}\right)$ & 533.1 & $\left(\mathrm{ng} / \mathrm{Pa} \cdot \mathrm{m}^{2} \cdot \mathrm{s}\right)$ \\
& 9.35 & US-perms \\
& 9.64 & US-perms (corrected) \\
\hline
\end{tabular}

\begin{tabular}{|c|c|c|c|c|c|}
\hline Data & & & & & using mo \\
\hline Date and Time & $\begin{array}{c}\text { Elapsed } \\
\text { Time } \\
\text { (days) }\end{array}$ & $\begin{array}{c}\text { Measured } \\
\text { Mass } \\
\text { (grams) }\end{array}$ & $\begin{array}{c}\Delta \text { mass } \\
\text { (grams) }\end{array}$ & $\begin{array}{l}\text { Included in } \\
\text { Curve-fit }\end{array}$ & Remarks \\
\hline $11 / 1 / 201610: 15$ & 0.00 & 440 & 0.00 & Y & Start of Test \\
\hline $11 / 2 / 201614: 22$ & 1.17 & 438 & -2.00 & Y & \\
\hline $11 / 3 / 201612: 40$ & 2.10 & 436.4 & -3.60 & $Y$ & \\
\hline $11 / 4 / 201616: 00$ & 3.24 & 434.6 & -5.40 & Y & \\
\hline $11 / 7 / 201613: 00$ & 6.11 & 429.1 & -10.9 & Y & \\
\hline $11 / 9 / 20169: 00$ & 7.95 & 426.1 & -13.9 & Y & \\
\hline $11 / 10 / 201615: 25$ & 9.22 & 423.9 & -16.1 & Y & \\
\hline $11 / 11 / 201614: 20$ & 10.17 & 422.1 & -17.9 & Y & \\
\hline $11 / 14 / 201613: 00$ & 13.11 & 416.8 & -23.2 & Y & \\
\hline
\end{tabular}

\section{Graph}

Sample High RH 4

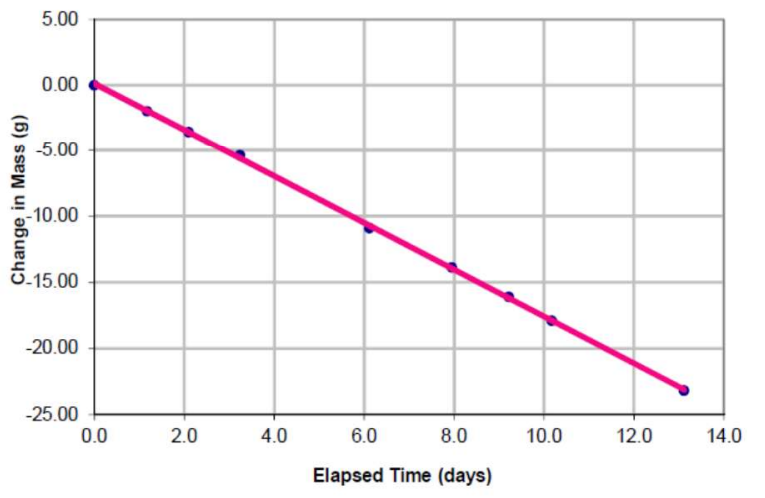

Testing Photo 


\begin{tabular}{|lcll|}
\hline \multicolumn{3}{|l|}{ Material Description } \\
\multicolumn{4}{l|}{ High RH 5 } \\
Sample ID & Cosella Dorken Nova Flexx & \\
Description & 0.155 & $(\mathrm{~m})$ & \\
Length & 0.154 & $(\mathrm{~m})$ & \\
Width & & $(\mathrm{m})$ & \\
Diameter & 0.0239 & $\left(\mathrm{~m}^{2}\right)$ & Exposed Area \\
Area & - & $(\mathrm{kg})$ & \\
Mass & & $\left(\mathrm{kg} / \mathrm{m}^{3}\right)$ & \\
Density & & $(\mathrm{m})$ & \\
Sample Thickness & & wet mils & \\
Film Thickness & & $\left(\mathrm{m}^{3}\right)$ & \\
Volume & & \\
\hline
\end{tabular}

\begin{tabular}{|c|c|c|c|}
\hline \multicolumn{4}{|c|}{ Analysis Results } \\
\hline $\begin{array}{l}\text { Slope } \\
\text { Intercept } \\
\mathrm{R}^{2}\end{array}$ & $\begin{array}{l}-1.769 \\
0.2186 \\
0.9977\end{array}$ & (g/day) & Notes \\
\hline $\begin{array}{l}\text { Cup Vp } \\
\text { Room Vp } \\
\text { delta Vp }\end{array}$ & $\begin{array}{l}3263 \\
1632 \\
1632\end{array}$ & $\begin{array}{l}(\mathrm{Pa}) \\
(\mathrm{Pa}) \\
(\mathrm{Pa})\end{array}$ & $\begin{array}{l}\text { assumed } \\
\text { measured }\end{array}$ \\
\hline Permeance $\left(\mathrm{M}_{\mathrm{T}}\right)$ & $\begin{array}{c}525.6 \\
9.22 \\
9.55\end{array}$ & $\begin{array}{l}\text { (ng/Pa.r } \\
\text { US-pern } \\
\text { US-pern }\end{array}$ & corrected) \\
\hline
\end{tabular}

\begin{tabular}{|c|c|c|c|c|c|}
\hline Data & & & & & using modified ASTM E96 \\
\hline Date and Time & $\begin{array}{c}\text { Elapsed } \\
\text { Time } \\
\text { (days) }\end{array}$ & $\begin{array}{c}\text { Measured } \\
\text { Mass } \\
\text { (grams) }\end{array}$ & $\begin{array}{c}\Delta \text { mass } \\
\text { (grams) }\end{array}$ & $\begin{array}{l}\text { Included in } \\
\text { Curve-fit }\end{array}$ & Remarks \\
\hline $11 / 1 / 201610: 15$ & 0.00 & 406.1 & 0.00 & Y & Start of Test \\
\hline $11 / 2 / 201614: 22$ & 1.17 & 404 & -2.10 & Y & \\
\hline $11 / 3 / 201612: 40$ & 2.10 & 402.5 & -3.60 & Y & \\
\hline $11 / 4 / 201616: 00$ & 3.24 & 400.6 & -5.50 & Y & \\
\hline $11 / 7 / 201613: 00$ & 6.11 & 395.9 & -10.2 & Y & \\
\hline $11 / 9 / 20169: 00$ & 7.95 & 392.8 & -13.3 & Y & \\
\hline $11 / 10 / 201615: 25$ & 9.22 & 390.3 & -15.8 & Y & \\
\hline $11 / 11 / 201614: 20$ & 10.17 & 388.4 & -17.7 & Y & \\
\hline $11 / 14 / 201613: 00$ & 13.11 & 382.4 & -23.7 & Y & \\
\hline
\end{tabular}

\section{Graph}

Sample High RH 5

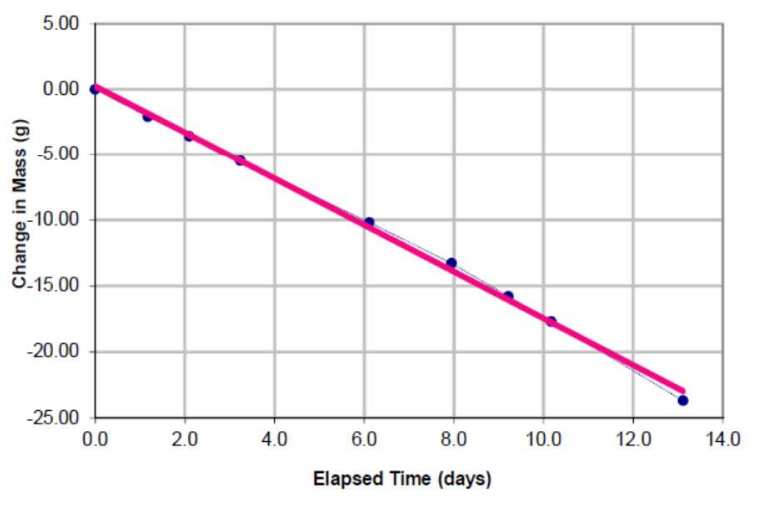

Testing Photo 
MRP Vapor Permeance Test

\begin{tabular}{|c|c|c|c|}
\hline \multicolumn{4}{|c|}{ Material Description } \\
\hline Sample ID & \multirow{2}{*}{\multicolumn{3}{|c|}{$\begin{array}{l}\text { Metal Deck } 1 \\
2-1 / 4 \text { " Holes }\end{array}$}} \\
\hline Description & & & \\
\hline Length & 0.3 & $(\mathrm{~m})$ & \\
\hline Width & 0.3 & $(\mathrm{~m})$ & \\
\hline Diameter & & $(\mathrm{m})$ & \\
\hline Area & 0.0900 & $\left(m^{2}\right)$ & Exposed Area \\
\hline Mass & - & $(\mathrm{kg})$ & \\
\hline Density & & $\left(\mathrm{kg} / \mathrm{m}^{3}\right)$ & \\
\hline Sample Thickness & & $(\mathrm{m})$ & \\
\hline $\begin{array}{l}\text { Film Thickness } \\
\text { Volume }\end{array}$ & & $\begin{array}{l}\text { wet mils } \\
\left(\mathrm{m}^{3}\right)\end{array}$ & \\
\hline
\end{tabular}

\begin{tabular}{|lcll|}
\hline Analysis Results & & & \\
& & & \\
Slope & -0.760 & $(\mathrm{~g} /$ day $)$ & Notes \\
Intercept & -3.0105 & & \\
$\mathrm{R}^{2}$ & 0.9951 & & \\
& & & \\
Cup Vp & 3263 & $(\mathrm{~Pa})$ & assumed \\
Room Vp & 1632 & $(\mathrm{~Pa})$ & measured \\
delta Vp & 1632 & $(\mathrm{~Pa})$ & \\
& & & \\
Permeance $\left(\mathrm{M}_{\mathrm{T}}\right)$ & 59.9 & (ng/Pa.m $\left.{ }^{2} \cdot \mathrm{s}\right)$ & \\
& 1.05 & US-perms & \\
& 1.02 & US-perms (corrected) \\
\hline
\end{tabular}

\begin{tabular}{|c|c|c|c|c|c|}
\hline Data & & & & & using modified ASTM E96 \\
\hline Date and Time & $\begin{array}{c}\text { Elapsed } \\
\text { Time } \\
\text { (days) }\end{array}$ & $\begin{array}{l}\text { Measured } \\
\text { Mass } \\
\text { (grams) }\end{array}$ & $\begin{array}{c}\Delta \text { mass } \\
\text { (grams) }\end{array}$ & $\begin{array}{l}\text { Included in } \\
\text { Curve-fit }\end{array}$ & Remarks \\
\hline $10 / 17 / 201614: 30$ & 0.00 & 2265.1 & 0.00 & & Start of Test \\
\hline 10/18/2016 10:00 & 0.81 & 2263.2 & -1.90 & & \\
\hline 10/20/2016 10:00 & 2.81 & 2259.9 & -5.20 & Y & \\
\hline $10 / 21 / 201614: 00$ & 3.98 & 2258.9 & -6.20 & Y & \\
\hline $10 / 24 / 201610: 00$ & 6.81 & 2257 & -8.1 & Y & \\
\hline $10 / 25 / 201614: 00$ & 7.98 & 2256.1 & -9.0 & Y & \\
\hline $10 / 26 / 201614: 00$ & 8.98 & 2255.3 & -9.8 & Y & \\
\hline $10 / 27 / 201611: 00$ & 9.85 & 2254.2 & -10.9 & Y & \\
\hline $10 / 31 / 201613: 30$ & 13.96 & 2251.6 & -13.5 & Y & \\
\hline $11 / 1 / 201610: 30$ & 14.83 & 2250.9 & -14.2 & Y & \\
\hline $11 / 2 / 201614: 15$ & 15.99 & 2250.3 & -14.8 & $Y$ & \\
\hline $11 / 3 / 201612: 48$ & 16.93 & 2248.8 & -16.3 & Y & \\
\hline $11 / 4 / 201616: 00$ & 18.06 & 2248.3 & -16.8 & Y & \\
\hline $11 / 7 / 201613: 00$ & 20.94 & 2247.5 & -17.6 & Y & \\
\hline 11/9/2016 9:00 & 22.77 & 2244.7 & -20.4 & Y & \\
\hline $11 / 10 / 201615: 35$ & 24.05 & 2243.5 & -21.6 & Y & \\
\hline $11 / 11 / 201614: 07$ & 24.98 & 2242.8 & -22.3 & Y & \\
\hline 11/14/2016 9:00 & 27.77 & 2240.7 & -24.4 & Y & \\
\hline
\end{tabular}

\section{Graph}

Sample Metal Deck 1

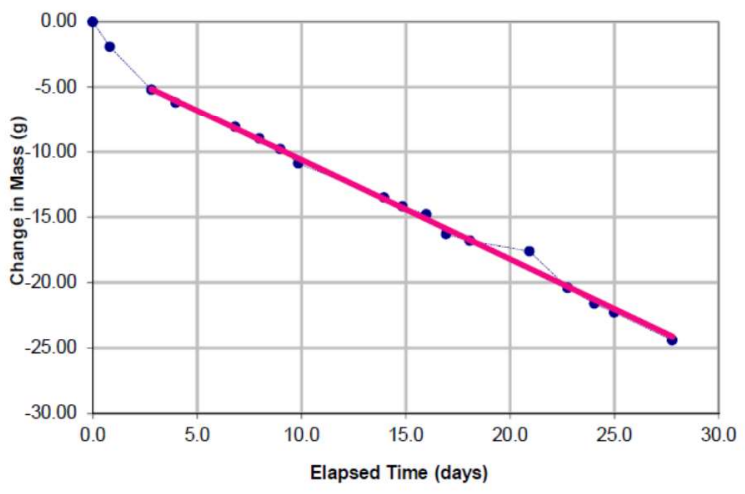

Testing Photo 
MRP Vapor Permeance Test

\begin{tabular}{|lcl|l|}
\hline \multicolumn{3}{|l|}{ Material Description } \\
Sample ID & \multicolumn{3}{l|}{ Metal Deck 2} \\
Description & $2-1 / 4 "$ Holes \\
Length & 0.3 & $(\mathrm{~m})$ & \\
Width & 0.3 & $(\mathrm{~m})$ & \\
Diameter & & $(\mathrm{m})$ & \\
Area & 0.0900 & $\left(\mathrm{~m}^{2}\right)$ & \\
Mass & - & $(\mathrm{kg})$ & \\
Density & & $\left(\mathrm{kg} / \mathrm{m}^{3}\right)$ & \\
Sample Thickness & & $(\mathrm{m})$ & \\
Film Thickness & & wet mils \\
Volume & & $\left(\mathrm{m}^{3}\right)$ \\
\hline
\end{tabular}

\begin{tabular}{|lrll|}
\hline Analysis Results & & & \\
Slope & -0.811 & $(\mathrm{~g} /$ day $)$ & Notes \\
Intercept & -9.5309 & & \\
$\mathrm{R}^{2}$ & 0.9934 & & \\
& & & assumed \\
Cup Vp & 3263 & $(\mathrm{~Pa})$ & measured \\
Room Vp & 1632 & $(\mathrm{~Pa})$ & \\
delta Vp & 1632 & $(\mathrm{~Pa})$ & \\
& & & \\
Permeance $\left(\mathrm{M}_{\mathrm{T}}\right)$ & 63.9 & (ng/Pa.m $\left.{ }^{2} \cdot \mathrm{s}\right)$ \\
& 1.12 & US-perms & \\
& 1.09 & US-perms (corrected) \\
\hline
\end{tabular}

Data $\left(\mathrm{m}^{3}\right)$

using modified ASTM E96

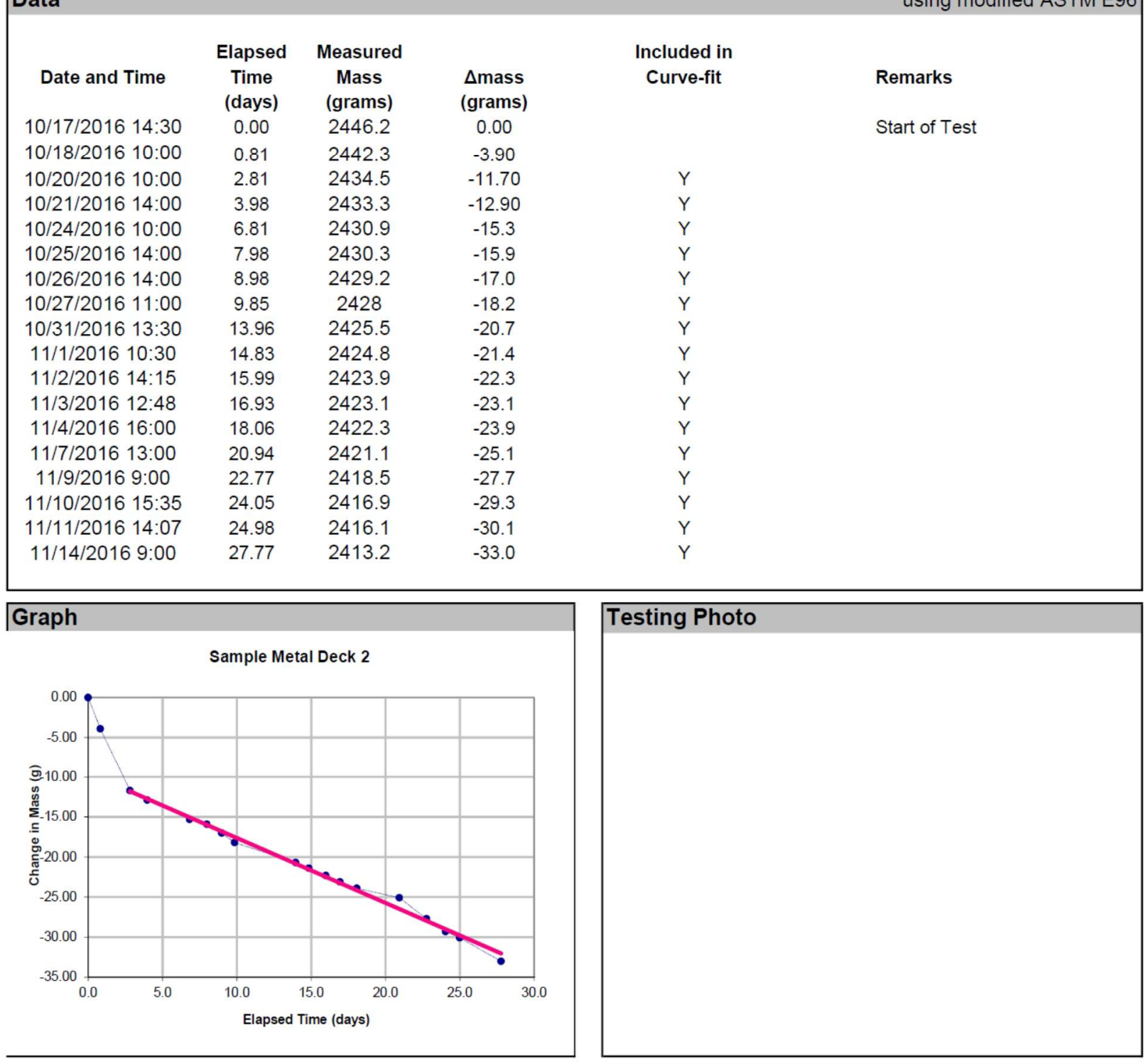


MRP Vapor Permeance Test

Material / Info

Method: Modified ASTM E96 Wet Cup

Data:

\begin{tabular}{|lcll|}
\hline \multicolumn{4}{l}{ Material Description } \\
\multicolumn{4}{l}{} \\
Sample ID & Metal Deck 3 & \\
Description & $2-1 / 4 "$ Holes & \\
Length & 0.3 & $(\mathrm{~m})$ & \\
Width & 0.3 & $(\mathrm{~m})$ & \\
Diameter & & $(\mathrm{m})$ & \\
Area & 0.0900 & $\left(\mathrm{~m}^{2}\right)$ & Exposed Area \\
Mass & - & $(\mathrm{kg})$ & \\
Density & & $\left(\mathrm{kg} / \mathrm{m}^{3}\right)$ & \\
Sample Thickness & & $(\mathrm{m})$ & \\
Film Thickness & & wet mils & \\
Volume & & $\left(\mathrm{m}^{3}\right)$ & \\
\hline
\end{tabular}

\begin{tabular}{|lrll|}
\hline Analysis Results & & & \\
& & & \\
Slope & -1.026 & $(\mathrm{~g} /$ day $)$ & Notes \\
Intercept & -3.8714 & & \\
$\mathrm{R}^{2}$ & 0.9965 & & \\
& & & \\
Cup Vp & 3263 & $(\mathrm{~Pa})$ & assumed \\
Room Vp & 1632 & $(\mathrm{~Pa})$ & measured \\
delta Vp & 1632 & $(\mathrm{~Pa})$ & \\
& & & \\
Permeance $\left(\mathrm{M}_{\mathrm{T}}\right)$ & 80.9 & $\left(\mathrm{ng} / \mathrm{Pa} \cdot \mathrm{m}^{2} \cdot \mathrm{s}\right)$ \\
& $\mathbf{1 . 4 2}$ & $\mathrm{US}-$ perms \\
& 1.38 & $\mathrm{US}-$ perms (corrected) \\
\hline
\end{tabular}

\begin{tabular}{|c|c|c|c|c|c|}
\hline Data & & & & & using modified ASTM E96 \\
\hline Date and Time & $\begin{array}{l}\text { Elapsed } \\
\text { Time } \\
\text { (days) }\end{array}$ & $\begin{array}{l}\text { Measured } \\
\text { Mass } \\
\text { (grams) }\end{array}$ & $\begin{array}{c}\Delta \text { mass } \\
\text { (grams) }\end{array}$ & $\begin{array}{l}\text { Included in } \\
\text { Curve-fit }\end{array}$ & Remarks \\
\hline $10 / 17 / 201614: 30$ & 0.00 & 2204.6 & 0.00 & & Start of Test \\
\hline 10/18/2016 10:00 & 0.81 & 2202.4 & -2.20 & & \\
\hline 10/20/2016 10:00 & 2.81 & 2197.9 & -6.70 & Y & \\
\hline 10/21/2016 14:00 & 3.98 & 2196.4 & -8.20 & Y & \\
\hline 10/24/2016 10:00 & 6.81 & 2193.8 & -10.8 & Y & \\
\hline $10 / 25 / 201614: 00$ & 7.98 & 2193.3 & -11.3 & Y & \\
\hline $10 / 26 / 201614: 00$ & 8.98 & 2191.9 & -12.7 & Y & \\
\hline 10/27/2016 11:00 & 9.85 & 2190 & -14.6 & Y & \\
\hline $10 / 31 / 201613: 30$ & 13.96 & 2186.1 & -18.5 & Y & \\
\hline $11 / 1 / 201610: 30$ & 14.83 & 2185.3 & -19.3 & Y & \\
\hline $11 / 2 / 201614: 15$ & 15.99 & 2184.3 & -20.3 & Y & \\
\hline $11 / 3 / 201612: 48$ & 16.93 & 2182.8 & -21.8 & $\mathrm{Y}$ & \\
\hline $11 / 4 / 201616: 00$ & 18.06 & 2182 & -22.6 & Y & \\
\hline $11 / 7 / 201613: 00$ & 20.94 & 2180.5 & -24.1 & Y & \\
\hline $11 / 9 / 20169: 00$ & 22.77 & 2177.3 & -27.3 & Y & \\
\hline $11 / 10 / 201615: 35$ & 24.05 & 2176 & -28.6 & Y & \\
\hline $11 / 11 / 201614: 07$ & 24.98 & 2174.8 & -29.8 & Y & \\
\hline $11 / 14 / 20169: 00$ & 27.77 & 2172.3 & -32.3 & Y & \\
\hline
\end{tabular}
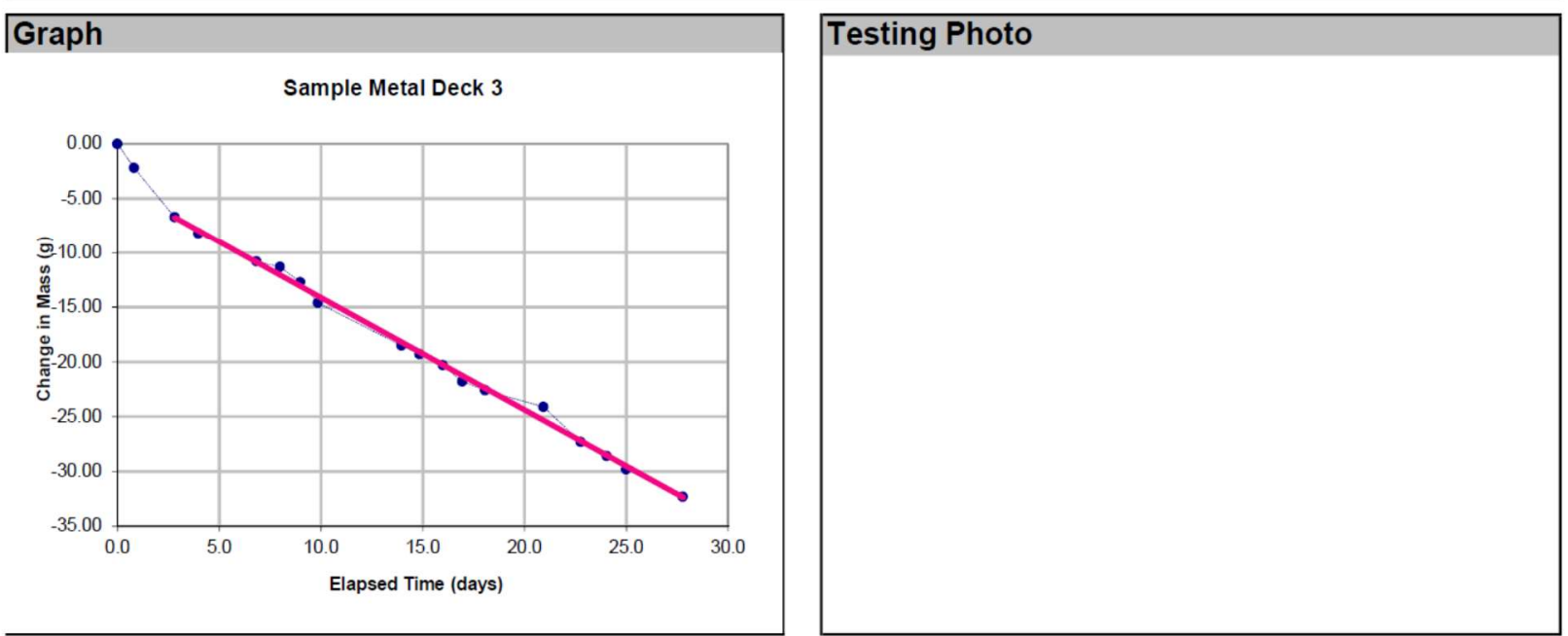
MRP Vapor Permeance Test

Material / Info

Method: Modified ASTM E96 Wet Cup

Data:

\begin{tabular}{|lcl|l|}
\hline \multicolumn{3}{|l|}{ Material Description } \\
Sample ID & Metal Deck 4 & \\
Description & $150 \mathrm{~mm}$ butt joint - 1 screw hole \\
Length & 0.3 & $(\mathrm{~m})$ & \\
Width & 0.3 & $(\mathrm{~m})$ & \\
Diameter & & $(\mathrm{m})$ & \\
Area & 0.0900 & $\left(\mathrm{~m}^{2}\right)$ & \\
Mass & - & $(\mathrm{kg})$ & \\
Density & & $\left(\mathrm{kg} / \mathrm{m}^{3}\right)$ & \\
Sample Thickness & & $(\mathrm{m})$ & \\
Film Thickness & & wet mils & \\
Volume & & $\left(\mathrm{m}^{3}\right)$ & \\
\hline
\end{tabular}

\begin{tabular}{|lcll|}
\hline Analysis Results & & & \\
& & & \\
Slope & -0.757 & $(\mathrm{~g} /$ day $)$ & Notes \\
Intercept & -6.8516 & & \\
$\mathrm{R}^{2}$ & 0.9912 & & \\
& & & \\
Cup Vp & 3263 & $(\mathrm{~Pa})$ & assumed \\
Room Vp & 1632 & $(\mathrm{~Pa})$ & measured \\
delta Vp & 1632 & $(\mathrm{~Pa})$ & \\
& & & \\
Permeance $\left(\mathrm{M}_{\mathrm{T}}\right)$ & 59.7 & $\left(\mathrm{ng} / \mathrm{Pa} \cdot \mathrm{m}^{2} \cdot \mathrm{s}\right)$ \\
& 1.05 & US-perms \\
& 1.00 & US-perms (corrected) \\
\hline
\end{tabular}

\begin{tabular}{|c|c|c|c|c|c|}
\hline Data & & & & & using modified ASTM E96 \\
\hline Date and Time & $\begin{array}{c}\text { Elapsed } \\
\text { Time } \\
\text { (days) }\end{array}$ & $\begin{array}{c}\text { Measured } \\
\text { Mass } \\
\text { (grams) }\end{array}$ & $\begin{array}{c}\Delta \text { mass } \\
\text { (grams) }\end{array}$ & $\begin{array}{l}\text { Included in } \\
\text { Curve-fit }\end{array}$ & Remarks \\
\hline $10 / 17 / 201614: 30$ & 0.00 & 2422.4 & 0.00 & & Start of Test \\
\hline $10 / 18 / 201610: 00$ & 0.81 & 2421.2 & -1.20 & & \\
\hline $10 / 20 / 201610: 00$ & 2.81 & 2414.6 & -7.80 & Y & \\
\hline $10 / 21 / 201614: 00$ & 3.98 & 2413.5 & -8.90 & Y & \\
\hline $10 / 24 / 201610: 00$ & 6.81 & 2409.9 & -12.5 & $Y$ & \\
\hline $10 / 25 / 201614: 00$ & 7.98 & 2409.1 & -13.3 & $Y$ & \\
\hline $10 / 26 / 201614: 00$ & 8.98 & 2408.3 & -14.1 & Y & \\
\hline $10 / 27 / 201611: 00$ & 9.85 & 2407.4 & -15.0 & Y & \\
\hline $10 / 31 / 201613: 30$ & 13.96 & 2404.3 & -18.1 & Y & \\
\hline $11 / 1 / 2016 \quad 10: 30$ & 14.83 & 2404.1 & -18.3 & Y & \\
\hline $11 / 2 / 201614: 15$ & 15.99 & 2403.5 & -18.9 & $Y$ & \\
\hline $11 / 3 / 201612: 48$ & 16.93 & 2402.5 & -19.9 & $Y$ & \\
\hline $11 / 4 / 201616: 00$ & 18.06 & 2401.9 & -20.5 & $Y$ & \\
\hline $11 / 7 / 201613: 00$ & 20.94 & 2399.6 & -22.8 & Y & \\
\hline 11/9/2016 9:00 & 22.77 & 2398.4 & -24.0 & Y & \\
\hline $11 / 10 / 201615: 35$ & 24.05 & 2397.7 & -24.7 & Y & \\
\hline $11 / 11 / 201614: 07$ & 24.98 & 2396.6 & -25.8 & Y & \\
\hline 11/14/2016 9:00 & 27.77 & 2395.2 & -27.2 & $Y$ & \\
\hline
\end{tabular}

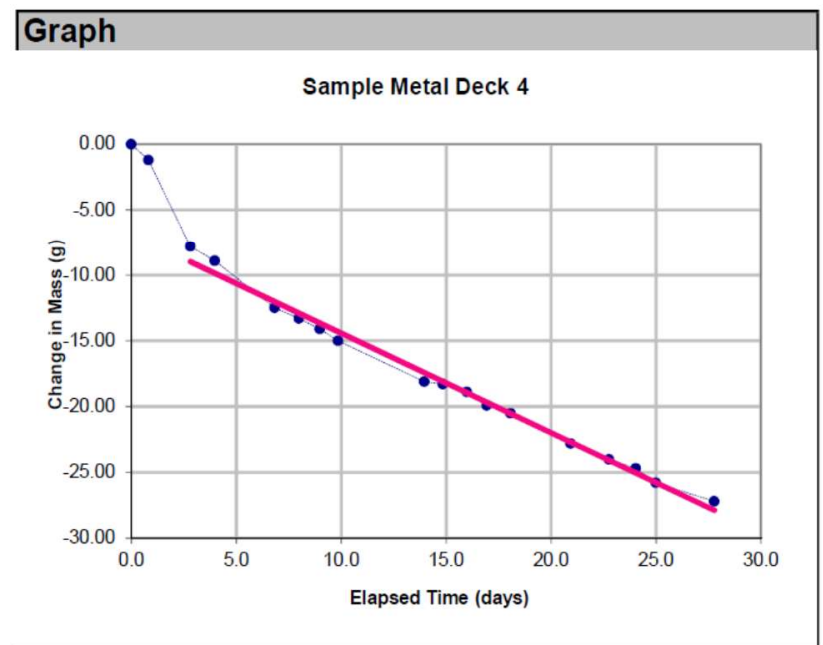

Testing Photo 
MRP Vapor Permeance Test

\begin{tabular}{|c|c|c|c|}
\hline \multicolumn{4}{|c|}{ Material Description } \\
\hline Sample ID & \multicolumn{3}{|c|}{ Metal Deck 5} \\
\hline Description & \multicolumn{3}{|c|}{$300 \mathrm{~mm}$ lap joing - 1 screw hold } \\
\hline Length & 0.3 & $(\mathrm{~m})$ & \\
\hline Width & 0.3 & $(\mathrm{~m})$ & \\
\hline Diameter & & $(\mathrm{m})$ & \\
\hline Area & 0.0900 & $\left(m^{2}\right)$ & Exposed Area \\
\hline Mass & - & $(\mathrm{kg})$ & \\
\hline Density & & $\left(\mathrm{kg} / \mathrm{m}^{3}\right)$ & \\
\hline Sample Thickness & & $(\mathrm{m})$ & \\
\hline Film Thickness & & wet mil & \\
\hline Volume & & $\left(\mathrm{m}^{3}\right)$ & \\
\hline
\end{tabular}

\begin{tabular}{|lcll|}
\hline Analysis Results & & & \\
& & & \\
Slope & -0.208 & $(\mathrm{~g} /$ day $)$ & Notes \\
Intercept & -1.5736 & & \\
$\mathrm{R}^{2}$ & 0.9842 & & \\
& & & \\
Cup Vp & 3263 & $(\mathrm{~Pa})$ & assumed \\
Room Vp & 1632 & $(\mathrm{~Pa}) \quad$ measured \\
delta Vp & 1632 & $(\mathrm{~Pa})$ & \\
& & & \\
Permeance $\left(\mathrm{M}_{\mathrm{T}}\right)$ & 16.4 & $\left(\mathrm{ng} / \mathrm{Pa} \cdot \mathrm{m}^{2} \cdot \mathrm{s}\right)$ \\
& 0.29 & US-perms \\
& 0.27 & US-perms (corrected) \\
\hline
\end{tabular}

\begin{tabular}{|c|c|c|c|c|c|}
\hline Data & & & & & using modified ASTM E96 \\
\hline Date and Time & $\begin{array}{c}\text { Elapsed } \\
\text { Time } \\
\text { (days) }\end{array}$ & $\begin{array}{l}\text { Measured } \\
\text { Mass } \\
\text { (grams) }\end{array}$ & $\begin{array}{c}\Delta \text { mass } \\
\text { (grams) }\end{array}$ & $\begin{array}{l}\text { Included in } \\
\text { Curve-fit }\end{array}$ & Remarks \\
\hline $10 / 17 / 201614: 30$ & 0.00 & 2379.9 & 0.00 & & Start of Test \\
\hline 10/18/2016 10:00 & 0.81 & 2379.9 & 0.00 & & \\
\hline $10 / 20 / 201610: 00$ & 2.81 & 2378.1 & -1.80 & & \\
\hline $10 / 21 / 201614: 00$ & 3.98 & 2377.1 & -2.80 & Y & \\
\hline $10 / 24 / 201610: 00$ & 6.81 & 2376.8 & -3.1 & Y & \\
\hline $10 / 25 / 201614: 00$ & 7.98 & 2376.7 & -3.2 & Y & \\
\hline $10 / 26 / 201614: 00$ & 8.98 & 2376.7 & -3.2 & Y & \\
\hline $10 / 27 / 201611: 00$ & 9.85 & 2376.6 & -3.3 & $Y$ & \\
\hline $10 / 31 / 201613: 30$ & 13.96 & 2375.4 & -4.5 & Y & \\
\hline $11 / 1 / 201610: 30$ & 14.83 & 2375.3 & -4.6 & Y & \\
\hline $11 / 2 / 201614: 15$ & 15.99 & 2375.1 & -4.8 & Y & \\
\hline $11 / 3 / 201612: 48$ & 16.93 & 2374.8 & -5.1 & Y & \\
\hline $11 / 4 / 201616: 00$ & 18.06 & 2374.4 & -5.5 & Y & \\
\hline $11 / 7 / 201613: 00$ & 20.94 & 2374.3 & -5.6 & Y & \\
\hline 11/9/2016 9:00 & 22.77 & 2373.5 & -6.4 & Y & \\
\hline $11 / 10 / 201615: 35$ & 24.05 & 2373.3 & -6.6 & Y & \\
\hline $11 / 11 / 201614: 07$ & 24.98 & 2373.1 & -6.8 & Y & \\
\hline 11/14/2016 9:00 & 27.77 & 2372.4 & -7.5 & Y & \\
\hline
\end{tabular}

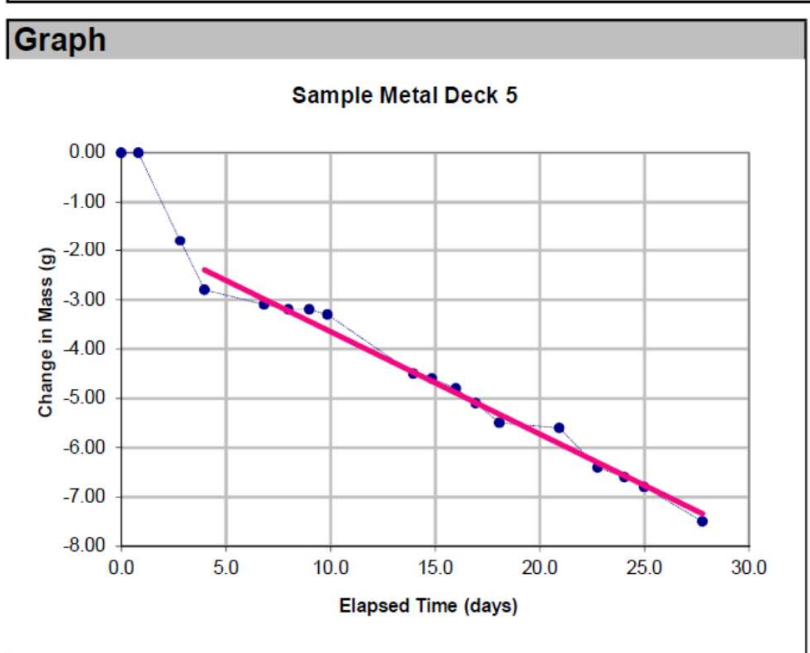

Testing Photo 


\subsection{APPENDIX F - ASTM E96 Laboratory Results}

\section{RD|†⿴囗十心}

To Mr. Rockford Boyer

EMAlLrockford.boyer@roxul.com

Roxul Inc.

8024 Esquesing Line

Milton ON L9T6W3
RDH Building Science Laboratories

167 Lexington Court \#5

Waterloo, ON N2J 4 R9

\subsection{0 \\ Roxul Full Scale Roof Testing in Waterloo, Ontario}

DATE July 13, 2016

REGARDING Intentional Wetting of Roofing Assemblies

Dear Mr. Boyer,

RDH Building Science Laboratories (RDH) is conducting testing of three Roxul roof assemblies at our field test site, located near Waterloo, ON. On June 6, 2016 controlled water injections were conducted into all three roof assemblies. This short report summarizes the roof assemblies, wetting event and preliminary results following the wetting event.

\section{Roof Assemblies}

The construction of the three roof assemblies is shown in Table 1. The water control layer (roofing membrane) on the roof assemblies is a 2-ply modified bitumen roofing membrane and the thermal control layer is two layers of 3" Roxul TopRock DD. TopRock $\mathrm{DD}+$ was installed as the top layer so the roofing membrane could be directly torched to it. The 2-ply modified bitumen roofing is both an air and vapour barrier on the exterior of the roofing assembly.

For Roofs 1 and 3, the air and vapour control on the metal roof deck is Soprema Sopravap'r vapour impermeable self-adhered membrane. Roof 2 uses Cosella Doerken Delta NovaFlexx smart membrane, which has a vapour permeance that varies with surrounding relative humidity. The structure and interior finish is metal roof deck for all three roof assemblies.

Metal roofing deck installed in real buildings is often filled with penetrations and holes. Holes were drilled in the metal deck for this research program based on previous research conducted on the effective vapour permeance of metal roof decks. 3/16" holes were drilled 10 " o.c. on every metal deck flute to allow some vapour diffusion.

Table 1 : Roofing Study Experimental Construction Variables

\begin{tabular}{|c|c|c|c|c|c|}
\hline $\begin{array}{l}\text { Roof } \\
\text { Panel }\end{array}$ & Structure & $\begin{array}{l}\text { Air/Vapor } \\
\text { Control }\end{array}$ & Thermal Control & $\begin{array}{l}\text { Water Control } \\
\text { Membrane }\end{array}$ & Notes \\
\hline 1 & $\begin{array}{l}\text { Metal roofing } \\
\text { deck }\end{array}$ & Sopravap'r & $2 \times 3 "$ TopRock DD & $\begin{array}{l}2 \text { ply mod bit } \\
\text { roofing }\end{array}$ & $\begin{array}{l}\text { Roof Vent } \\
\text { installed }\end{array}$ \\
\hline 2 & $\begin{array}{l}\text { Metal roofing } \\
\text { deck }\end{array}$ & CD NovaFlexx & $2 \times 3 "$ TopRock DD & $\begin{array}{l}2 \text { ply mod bit } \\
\text { roofing }\end{array}$ & \\
\hline 3 & $\begin{array}{l}\text { Metal roofing } \\
\text { deck }\end{array}$ & Sopravap'r & $2 \times 3 "$ TopRock DD & $\begin{array}{l}2 \text { ply mod bit } \\
\text { roofing }\end{array}$ & \\
\hline
\end{tabular}




\section{RDH}

rdh.com

A wetting system was installed in each of the roof assemblies as shown by the blue squares in the schematic drawing (Figure 1) and in the installation photo Figure 2. The wetting system allows a controlled amount of water to be injected to a controlled location simulating a roof leak, or construction moisture between the layers of Roxul TopRock insulation. The objective is to determine the re-distribution of the moisture and if there is any drying potential in the different roof assemblies. The first wetting event was started on June 6, 2016.



Figure 1: Schematic of test roof assembly with sensors and dimensions

Figure 2 shows the combination relative humidity, moisture content and temperature sensors at the $A, B$, and $C$ locations on Roof panel 2 as described in Figure 1. A plastic tube was installed to the centre of the wetting storage media from the interior of the test hut to enable a controlled amount of water to be injected to a controlled location. 


\section{RDH}

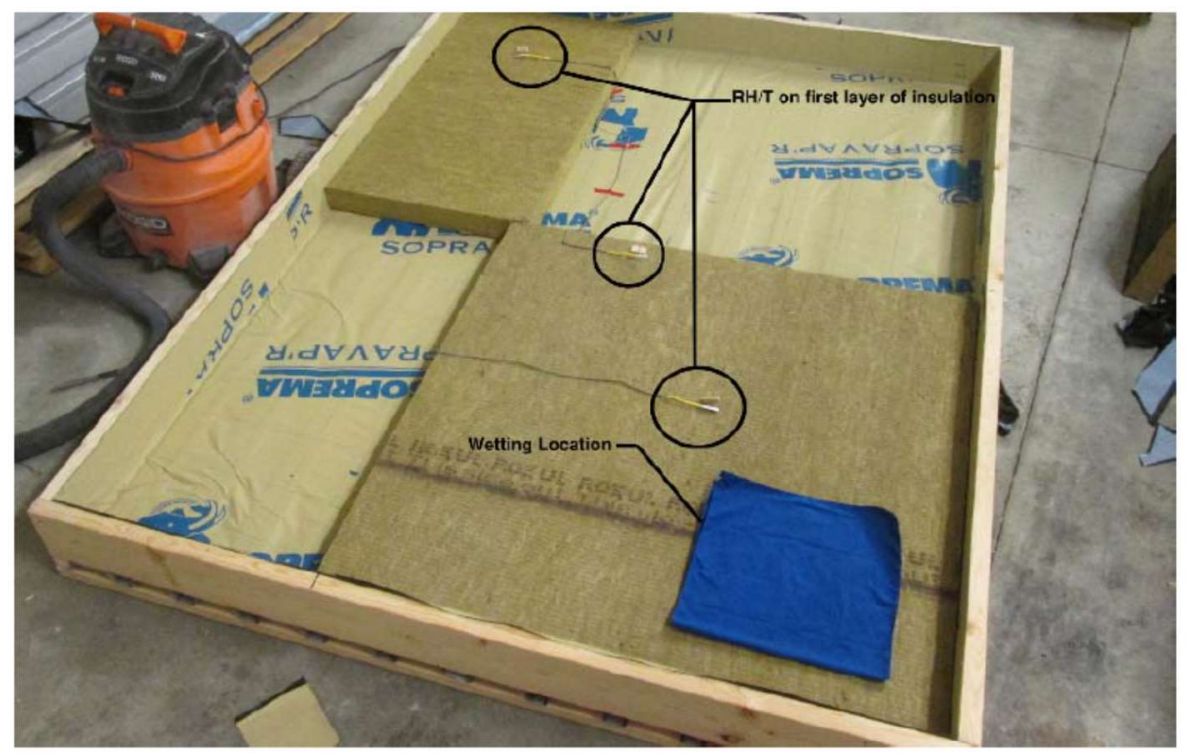

Figure 2 : Roof 2 relative humidity, wood moisture content wafers and temperature sensors along with wetting apparatus installed on first layer of insulation

\section{Research Objective}

The objective of the controlled wetting events is to determine based on measured moisture content and relative humidity data if any of the roofing systems being tested are able to dry out passively, that is, without making roof openings, or using mechanical means to promote drying of the roofing assembly. The standard construction of roof panel 2 with an air and vapour barrier above and below the insulation is not expected to have any drying ability. Roof panel 3 with the smart vapour retarder air barrier installed over the metal deck is expected to allow some amount of drying to the interior, and Roof panel 1 with a vapour diffusion port may allow slower drying of the roofing assembly.

\section{Controlled Wetting Event - June 6, 2016}

Water injections commenced in the morning of June 6, 2016. A total of $750 \mathrm{~mL}$ of water was injected over 5 days, $75 \mathrm{~mL}$ twice a day in the morning and afternoon. This water was injected through a plastic tube to the centre of the water storage media in the location shown in Figure 2.

Figure 4 shows the measured moisture content for all three roof assemblies at monitoring location A (Figure 3), approximately $18^{\prime \prime}$ from the middle of the wetting system. It is clear from the graph that the moisture content wafer in roof assembly three with a smart vapour retarder air barrier dried in approximately 3-4 weeks. Roof assemblies 1 and 2 are showing no definitive drying in the first five weeks following the intentional wetting event. 


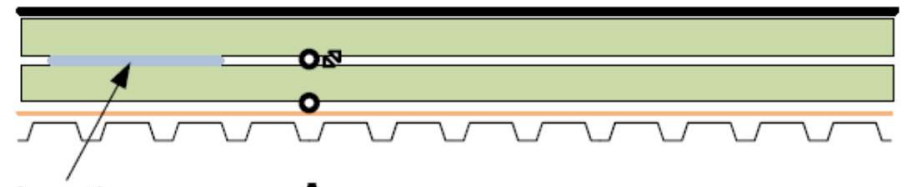

Wetting Location

Airroos

- Relative Humidity and Temperature Sensor Package

$\Delta$ Temperature Sensor

$\Delta$ Moisture Content Wafer and Temperature Sensor Package

Figure 3 : Sensors at Location A in all roof panels used for preliminary analysis of the intentional wetting event.

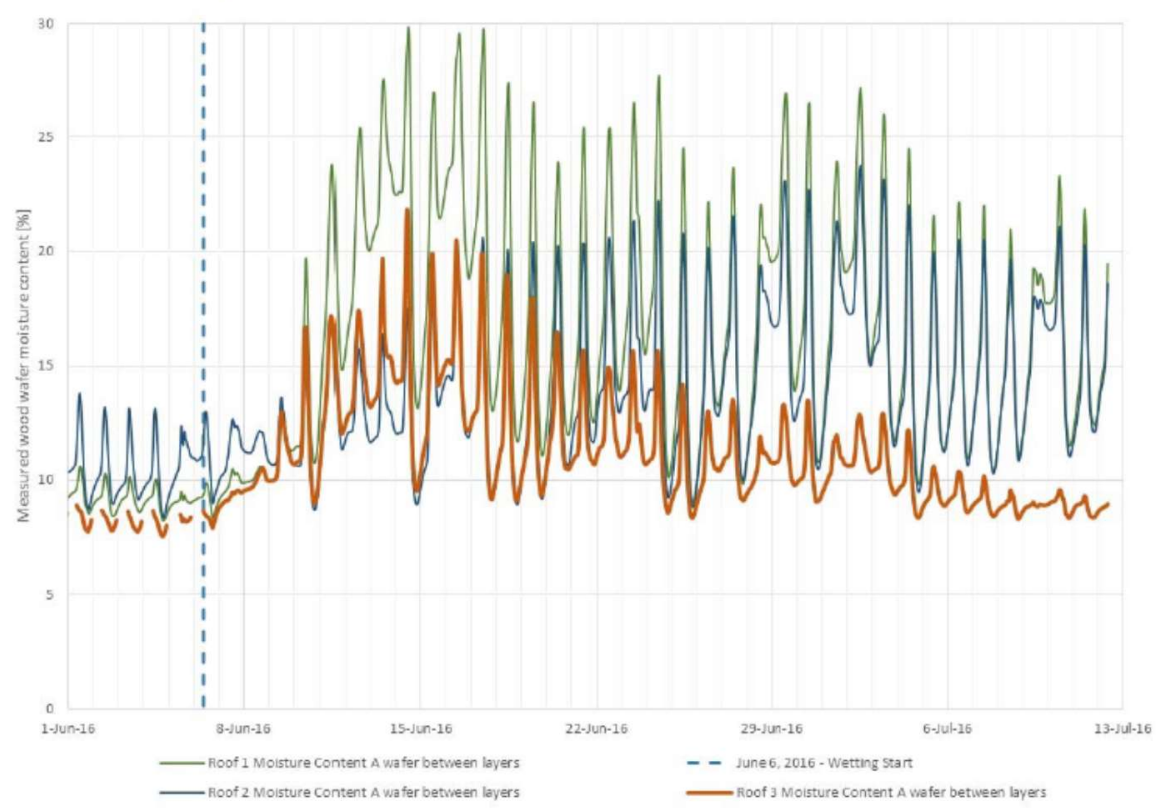

Figure 4 : Measured moisture content at Location $A$ in all three roof assemblies following the intentional wetting event.

The measured relative humidity in all three roofing assemblies at Location A below the insulation is shown in Figure 5. Roof assemblies 1 and 2 are showing measured relative humidity at $100 \%$ that occasionally falls to $90 \%$ at Location A below the insulation five weeks following the wetting event. Roof 3 constructed with the smart vapour retarder air barrier has a much lower measured relative humidity between $30 \%$ and $90 \%$ at the five week period indicating that most of the water has dried from below the insulation following the wetting event. 


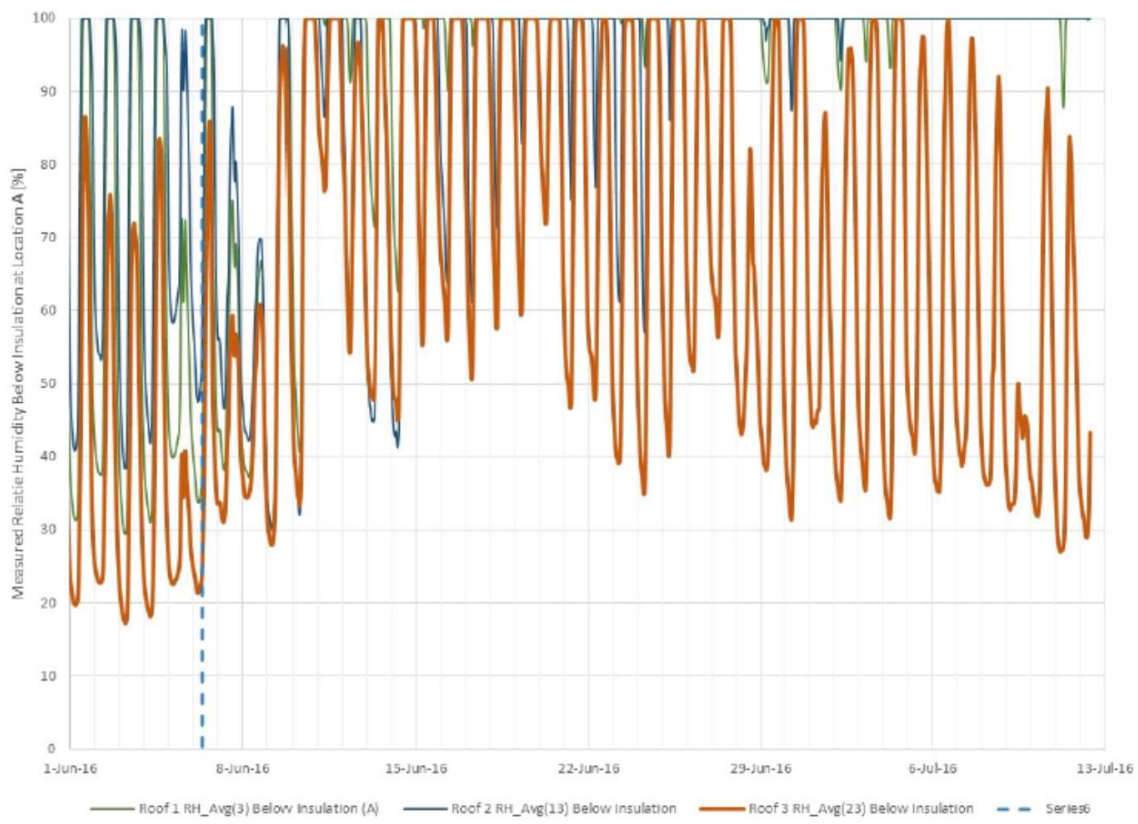

Figure 5 : Measured relative humidity at Location A below the roofing insulation in all Roof Systems.

Figure 6 shows the measured relative humidity between the two layers of 3 " TopRock roofing insulation at Location A (Figure 3 ) approximately 18 inches from the site of water injection. Initially there was in increase in the relative humidity of all of the roofing assemblies, but after five weeks, the measured relative humidity in Roof 3 is significantly lower than Roofs 1 and 2. Roofing assembly 3 with a smart vapour retarder was able to dry to the interior. 


\section{RDH}

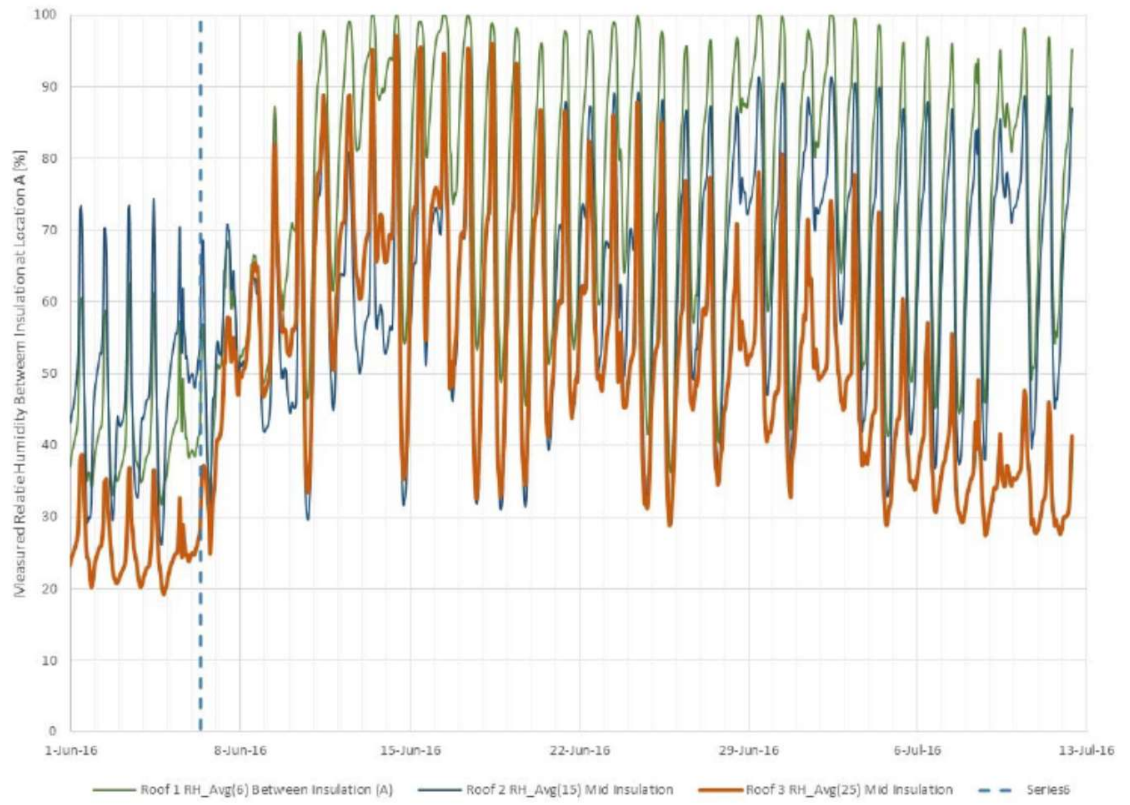

Figure 6 : Measured relative humidity at Location A between the insulation layers in all Roof Systems.

\section{Conclusions}

The preliminary analysis following the intentional wetting event demonstrates that Roof assembly 3 with a smart vapour retarder air barrier installed over the metal deck allows $750 \mathrm{~mL}$ of injected water to mostly dry within five weeks of wetting. Roofing assemblies 1 and 2 with more traditional construction of a vapour barrier installed on the roof deck, show no definitive drying after five weeks of time. The vapour diffusion port on roof assembly one did not have any definitive improved performance over roof assembly 2, but drying may be slower than the preliminary monitoring period of five weeks with the vapour diffusion port.

Please let me know if you have any questions once you have reviewed this report. Yours truly,

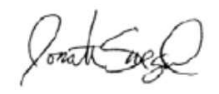

Jonathan Smegal

Senior Project Manager

jsmegal@rdh.com

RDH Building Science Inc. 


\subsection{APPENDIX G - Metal Deck Venting Strategies}

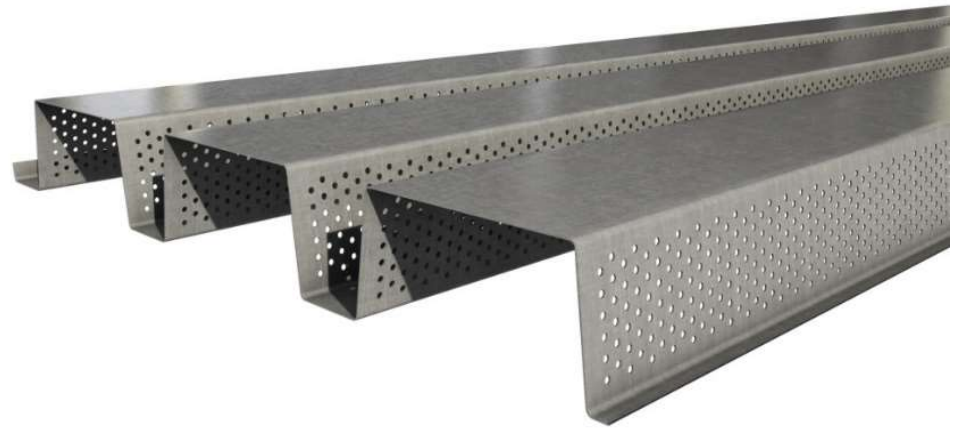

The use of an acoustical metal deck will potentially allow for adequate venting of the increased $\mathrm{RH}$ between the membrane and metal deck; however, the vapour permeability will be drastically increased. This will be a potential benefit in the cooling season and a negative in the heating season.

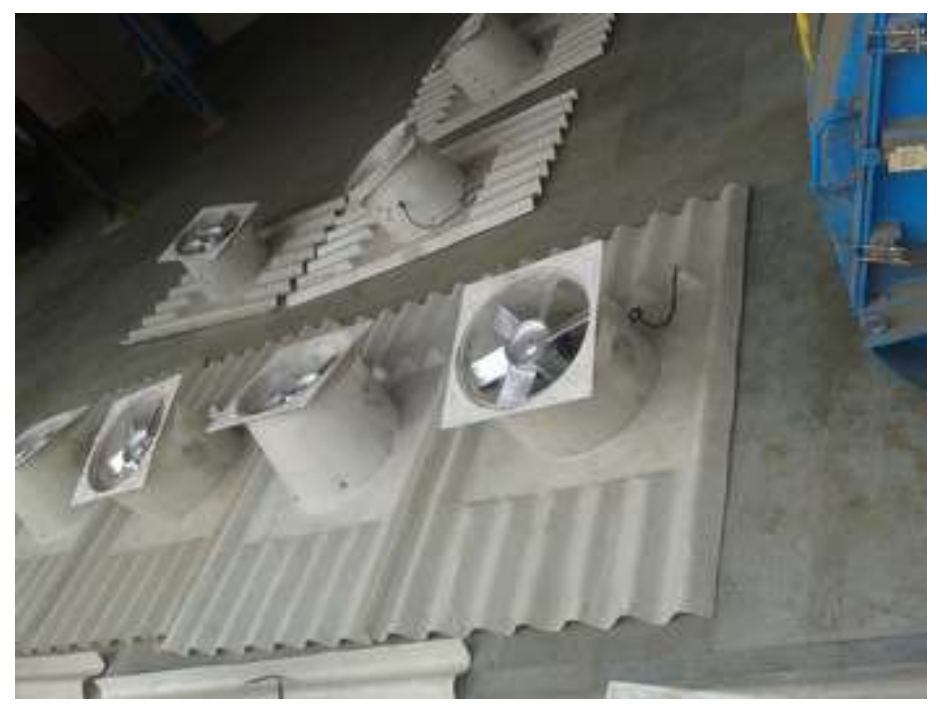

Mechanical ventilation with active ventilation between the metal deck and underside of membrane (create paths) can remove the unwanted moisture in the metal deck via negative pressure. The mechanical fan can introduce minimal pressure to exfiltrate the moisture latent air to the exterior. The mechanical ventilation shall only run during the heating season and shall cease during the cooling season as not to introduce moisture latent air from exterior.

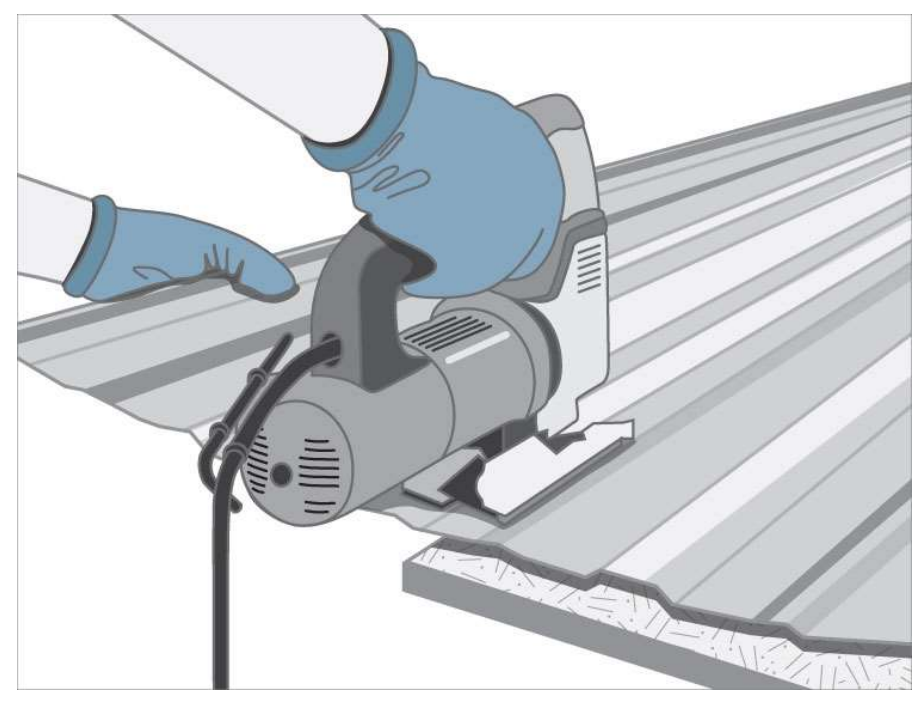

Cutting several ends of the metal deck while introducing an air cavity pathway above has the potential to remove unwanted moisture between the metal deck and the underside of the smart membrane. A small mechanical system will have to be introduced to create air convection between the conditioned space and the air cavity pathway. This scenario is only required during the heating season. 


\subsection{APPENDIX H - Simulation Results}

EDMONTON, AB - Passive
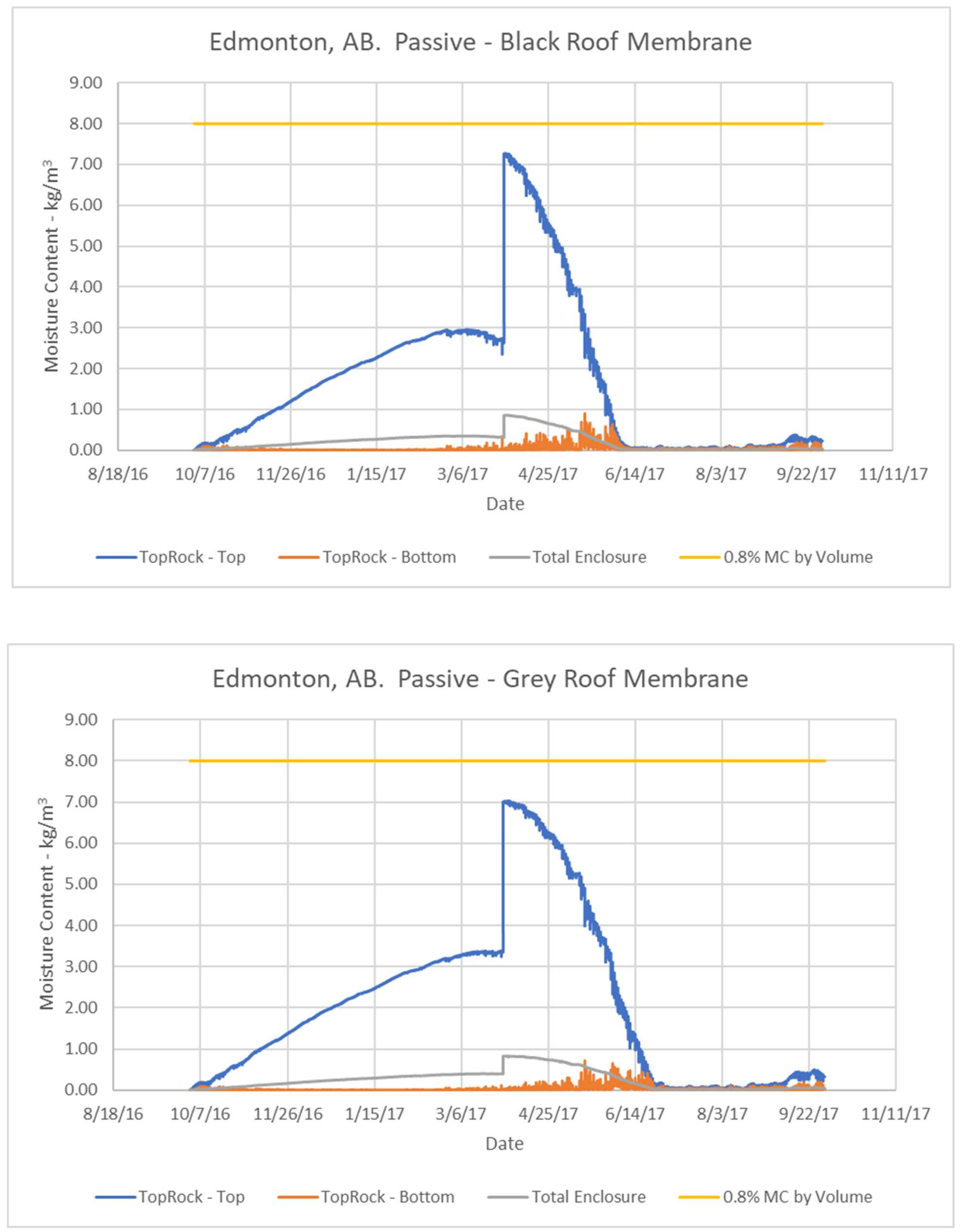


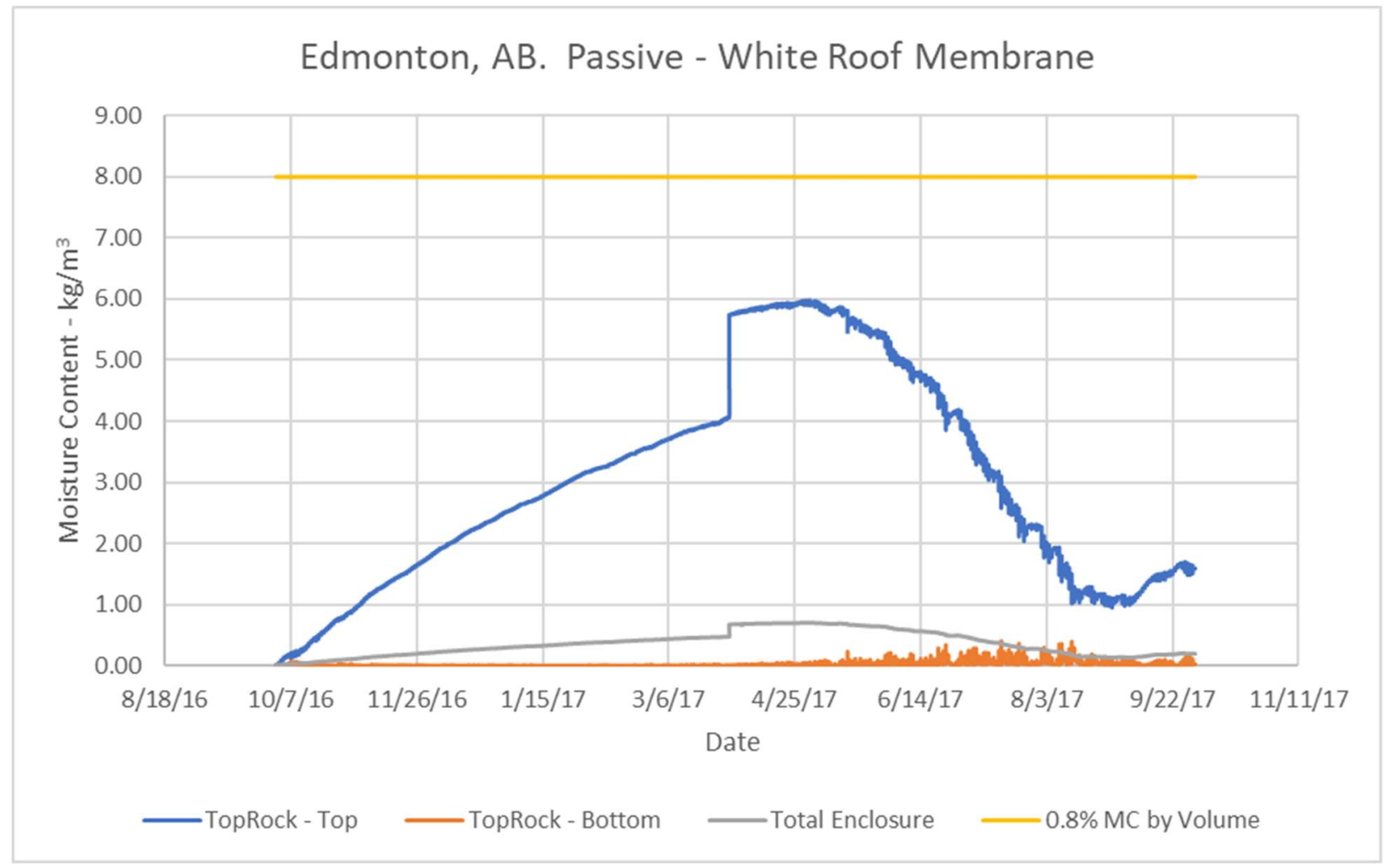

MONTREAL, QC - Passive

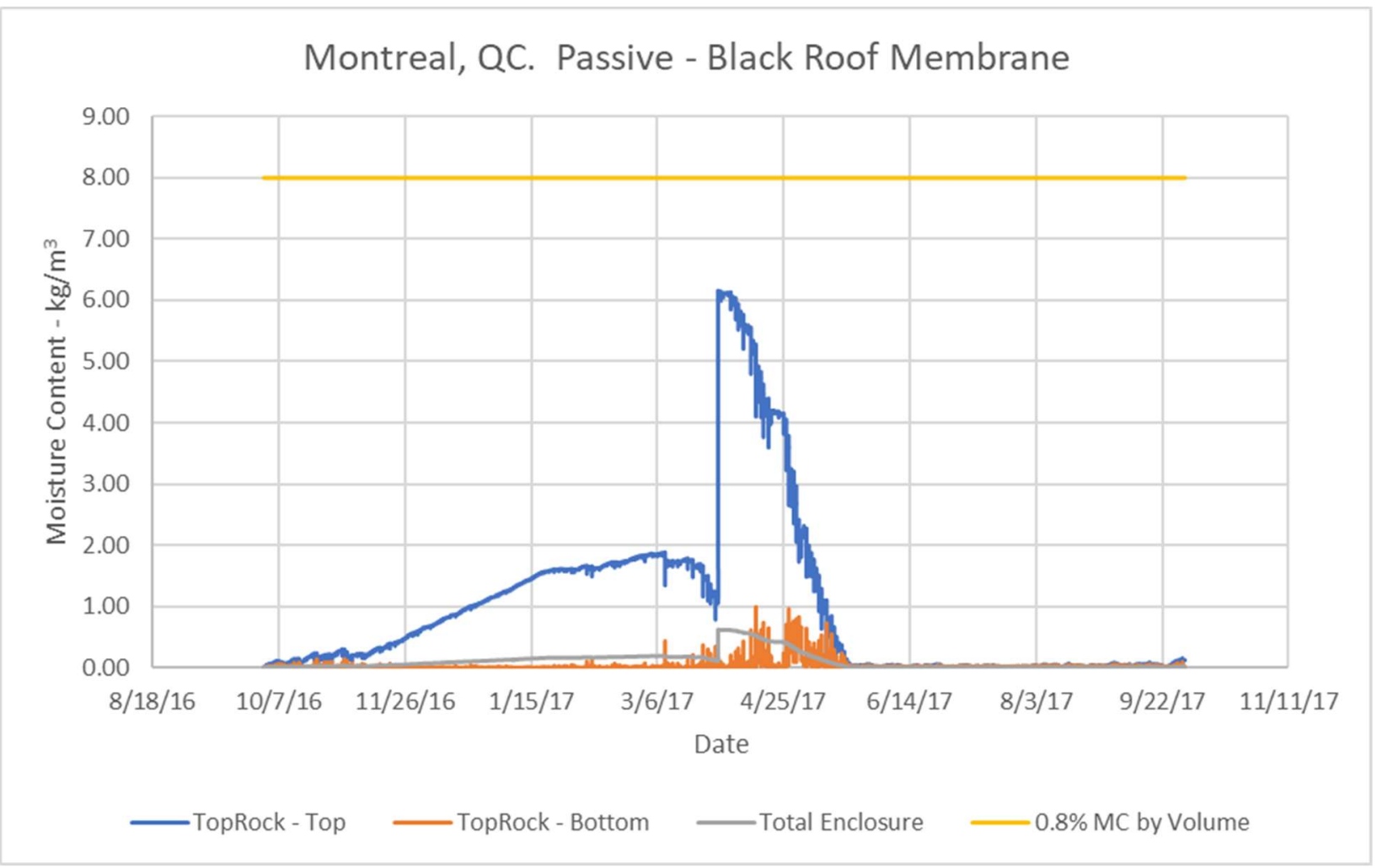



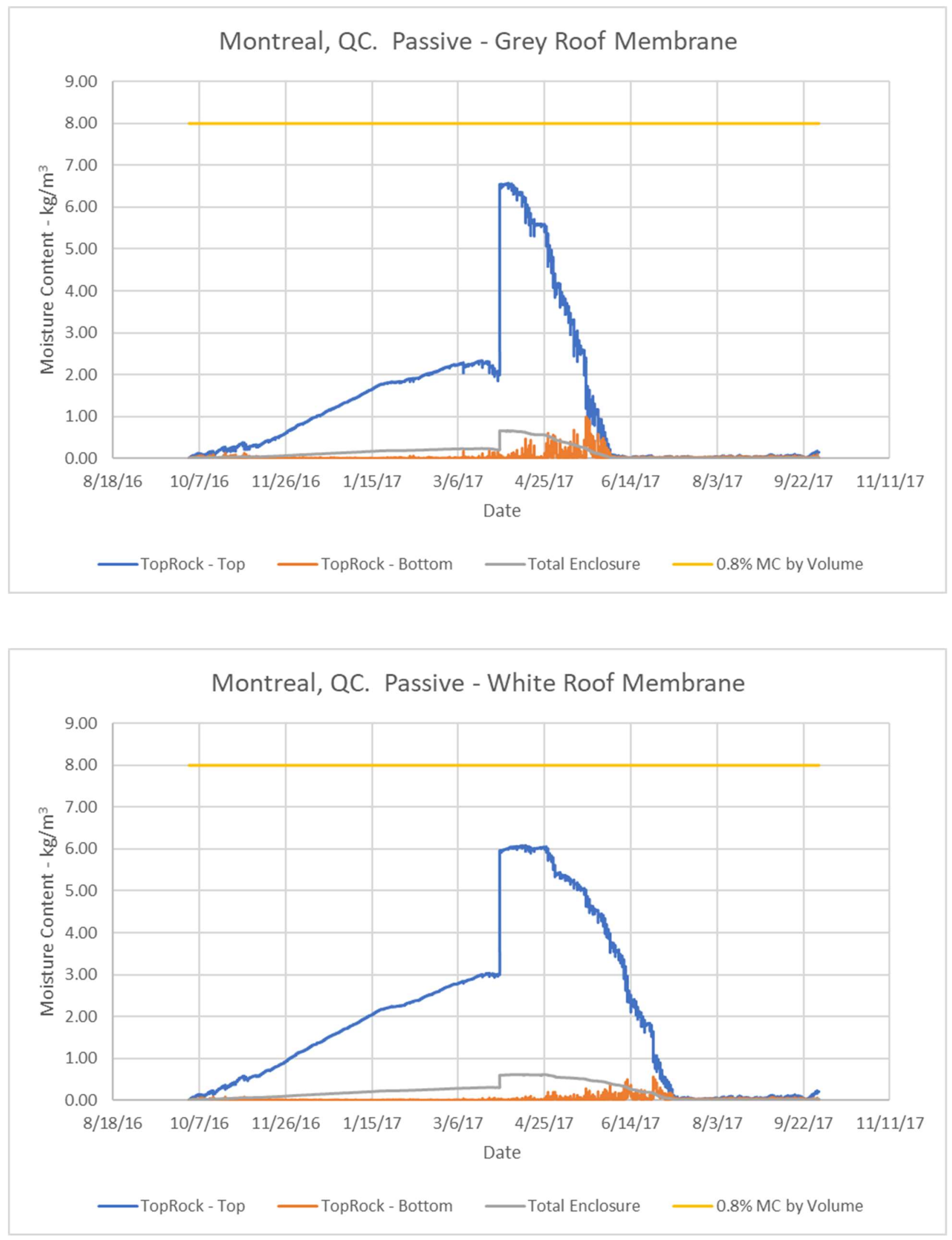


\section{ST. JOHN'S, NFLD - Passive}
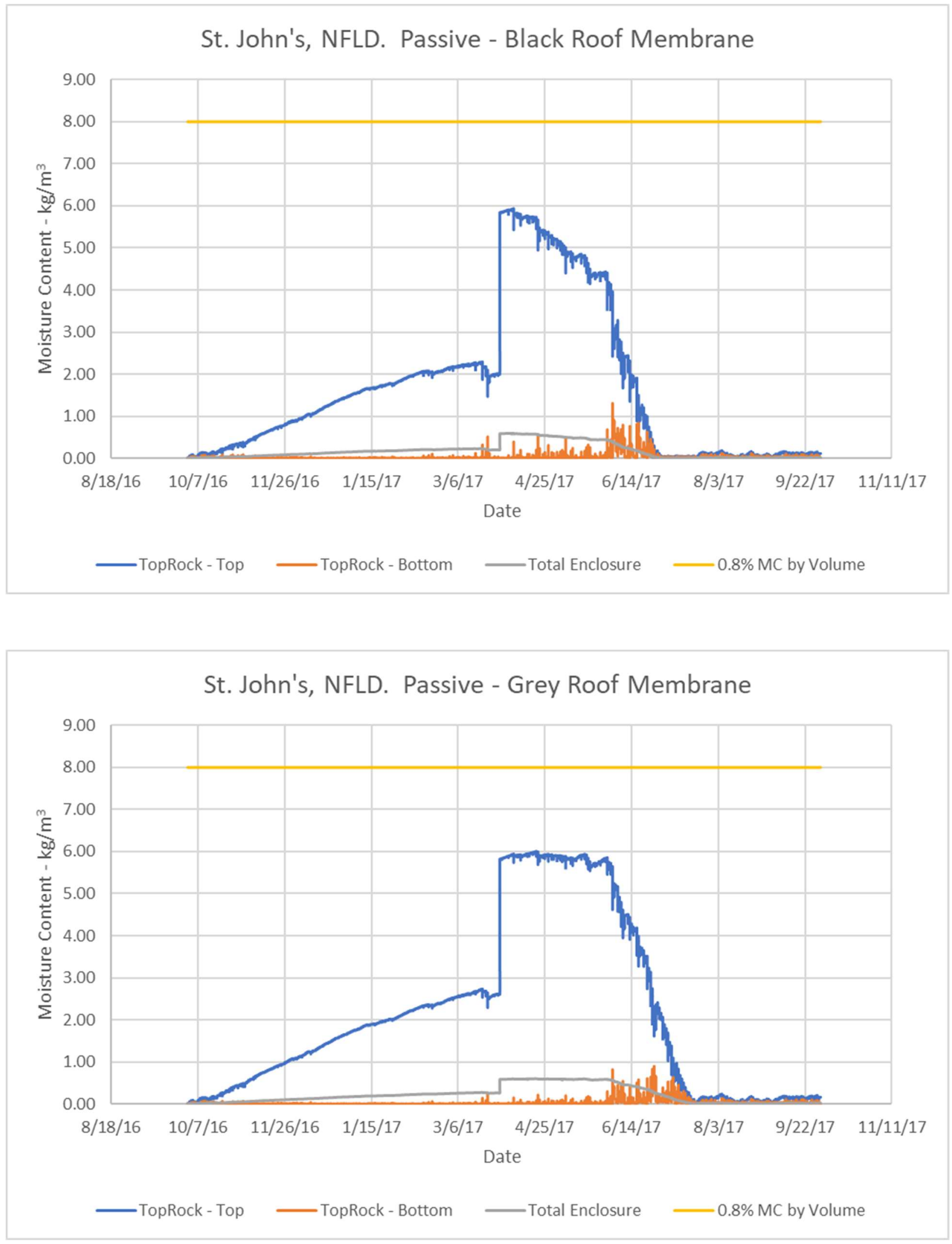


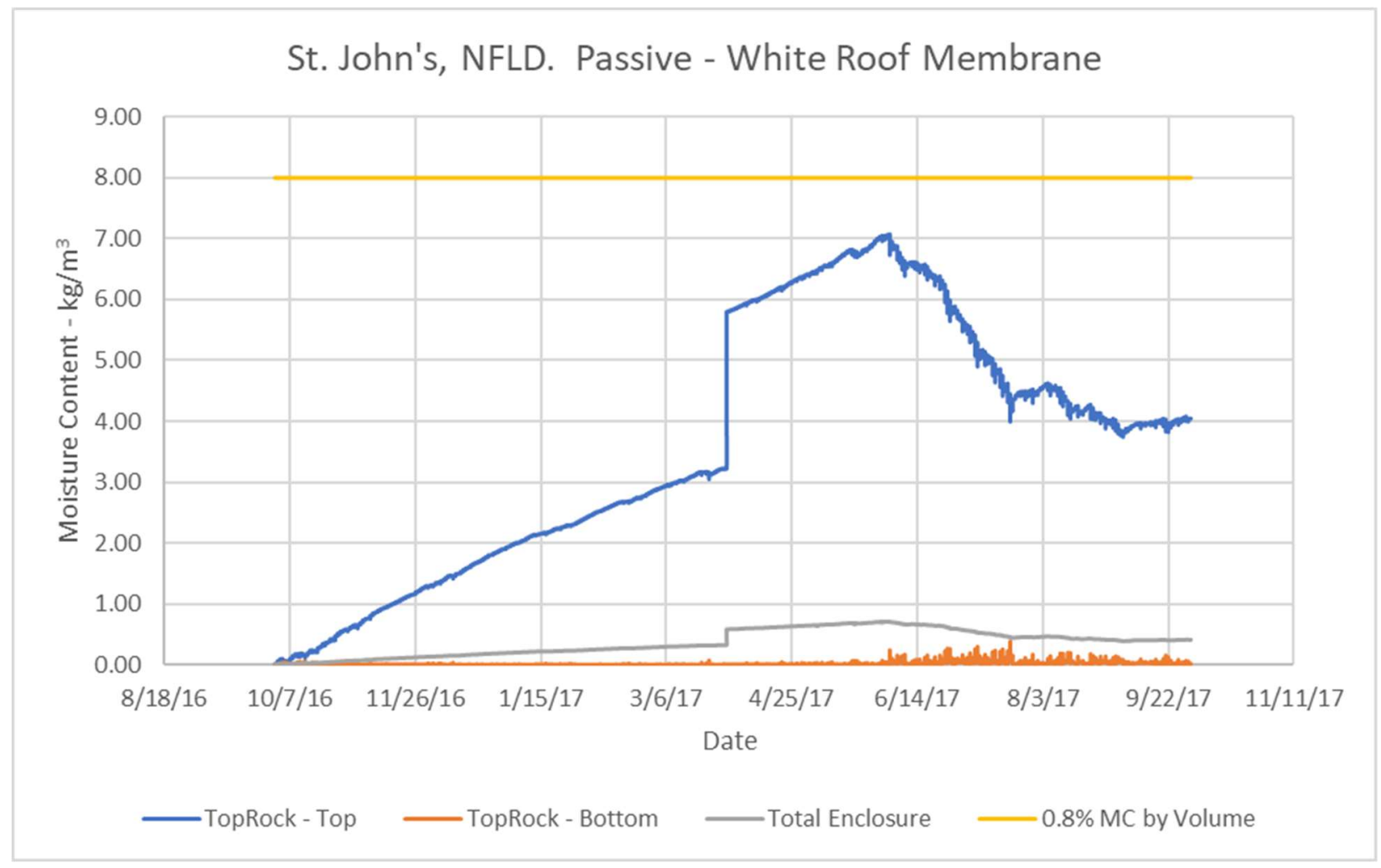

TORONTO, ON - Passive

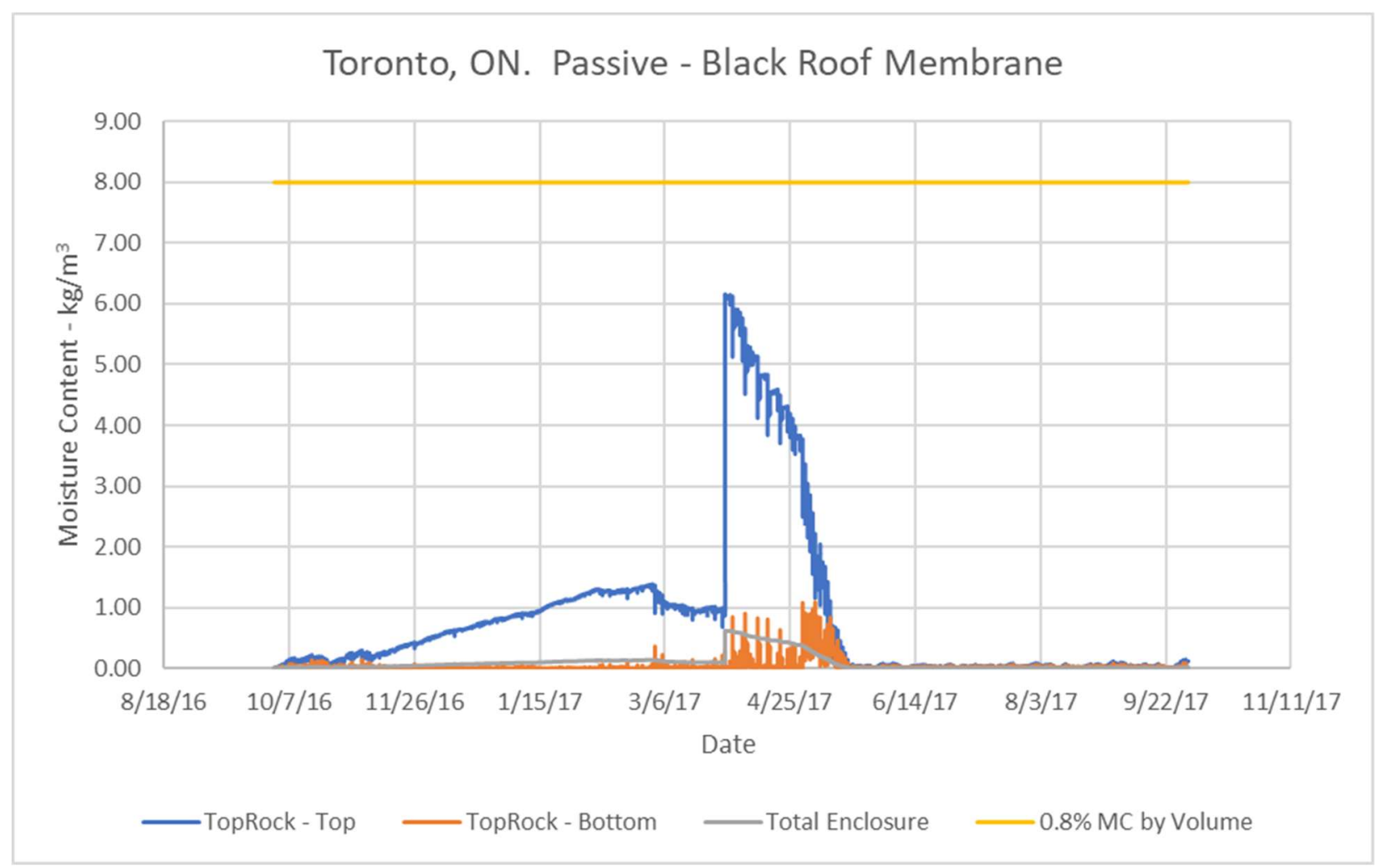



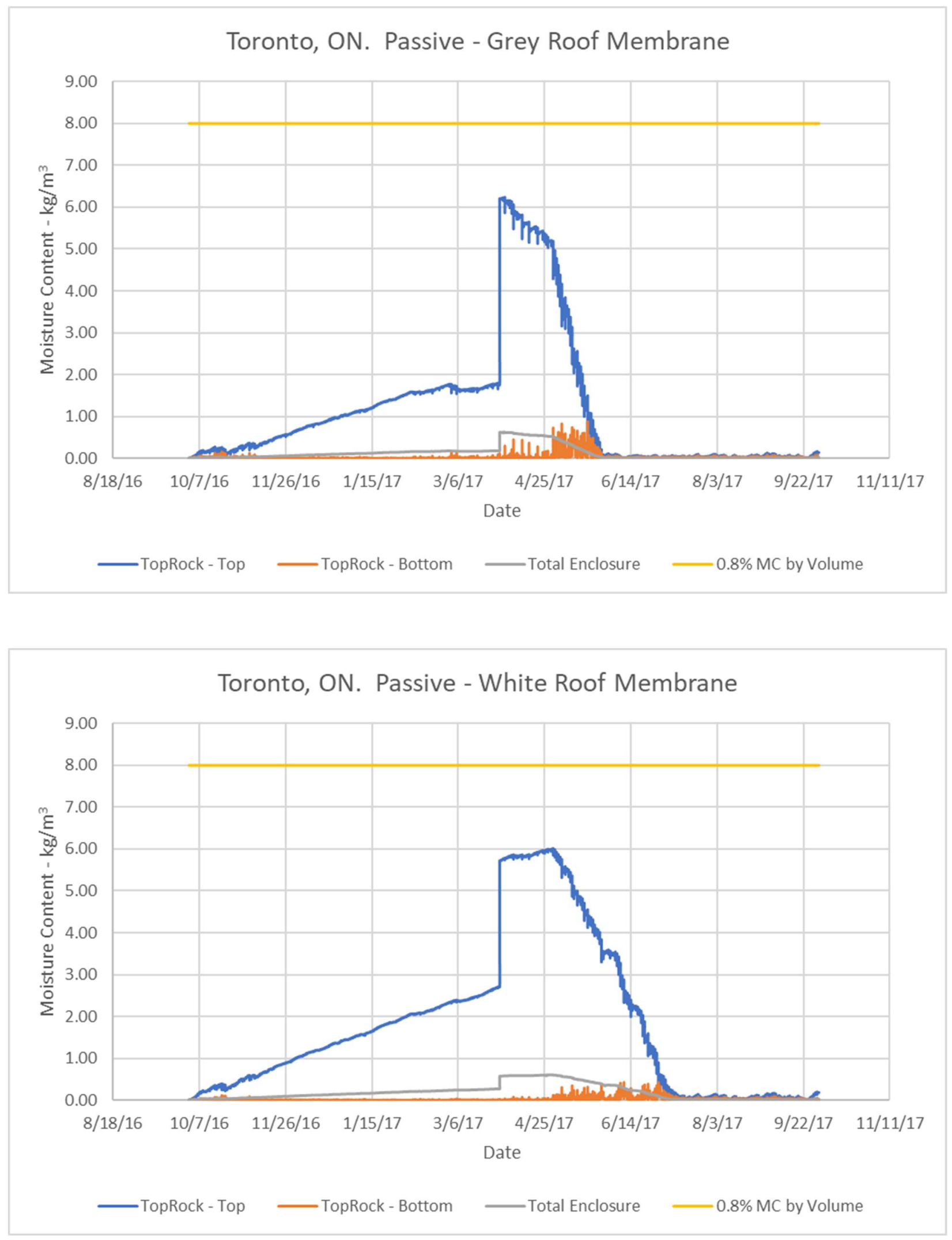


\section{VANCOUVER, BC-Passive}
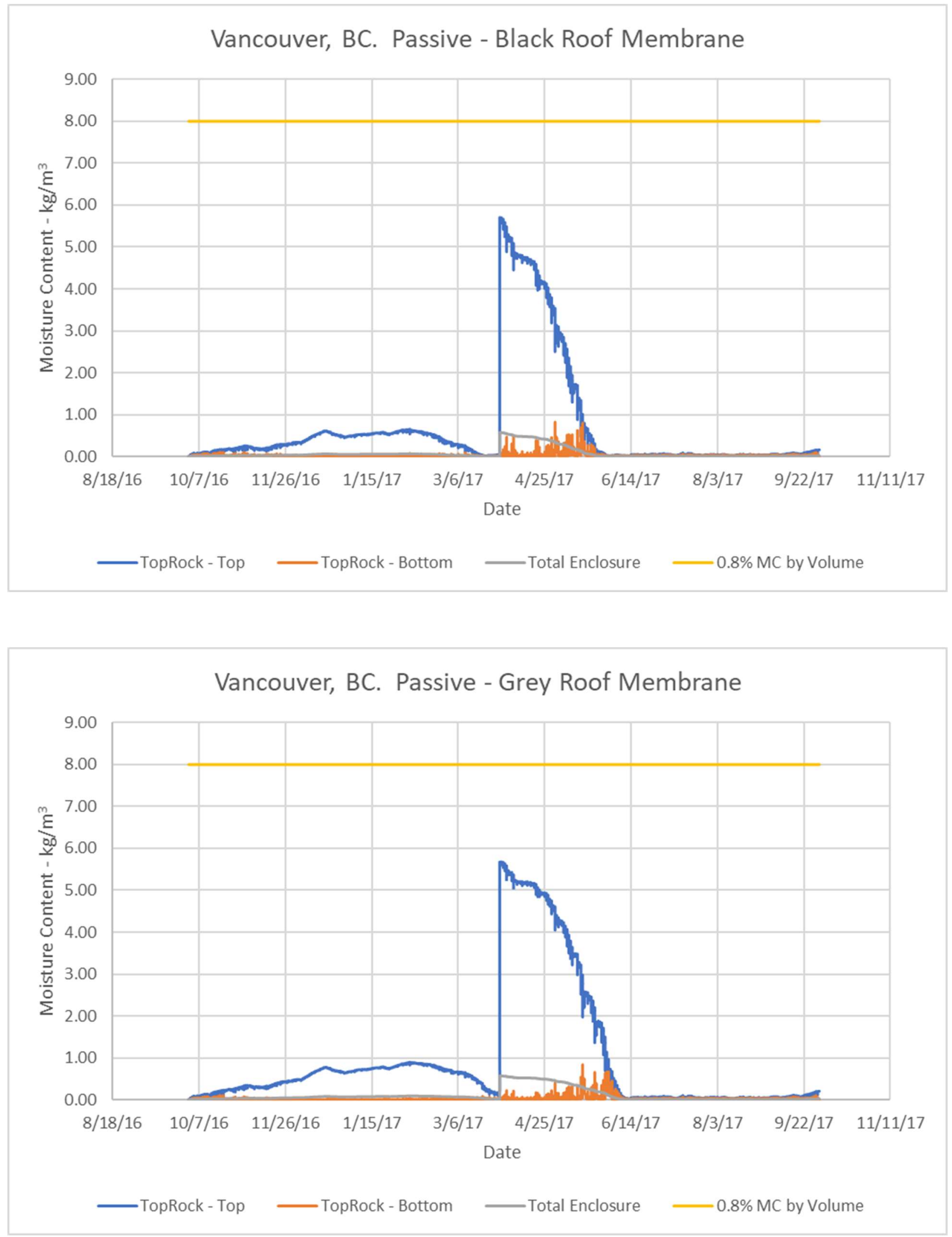


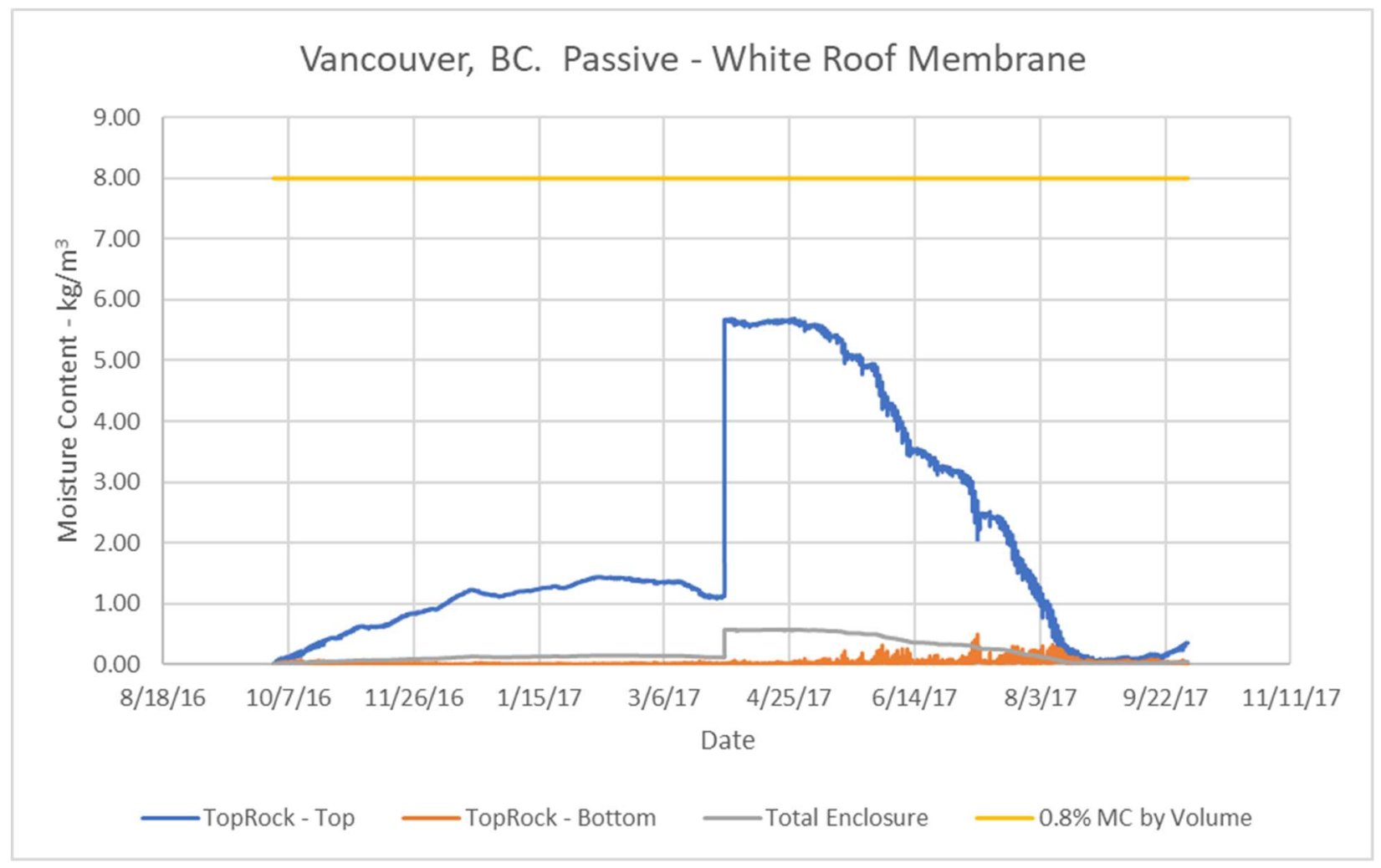

\section{BOISE, ID - Passive}

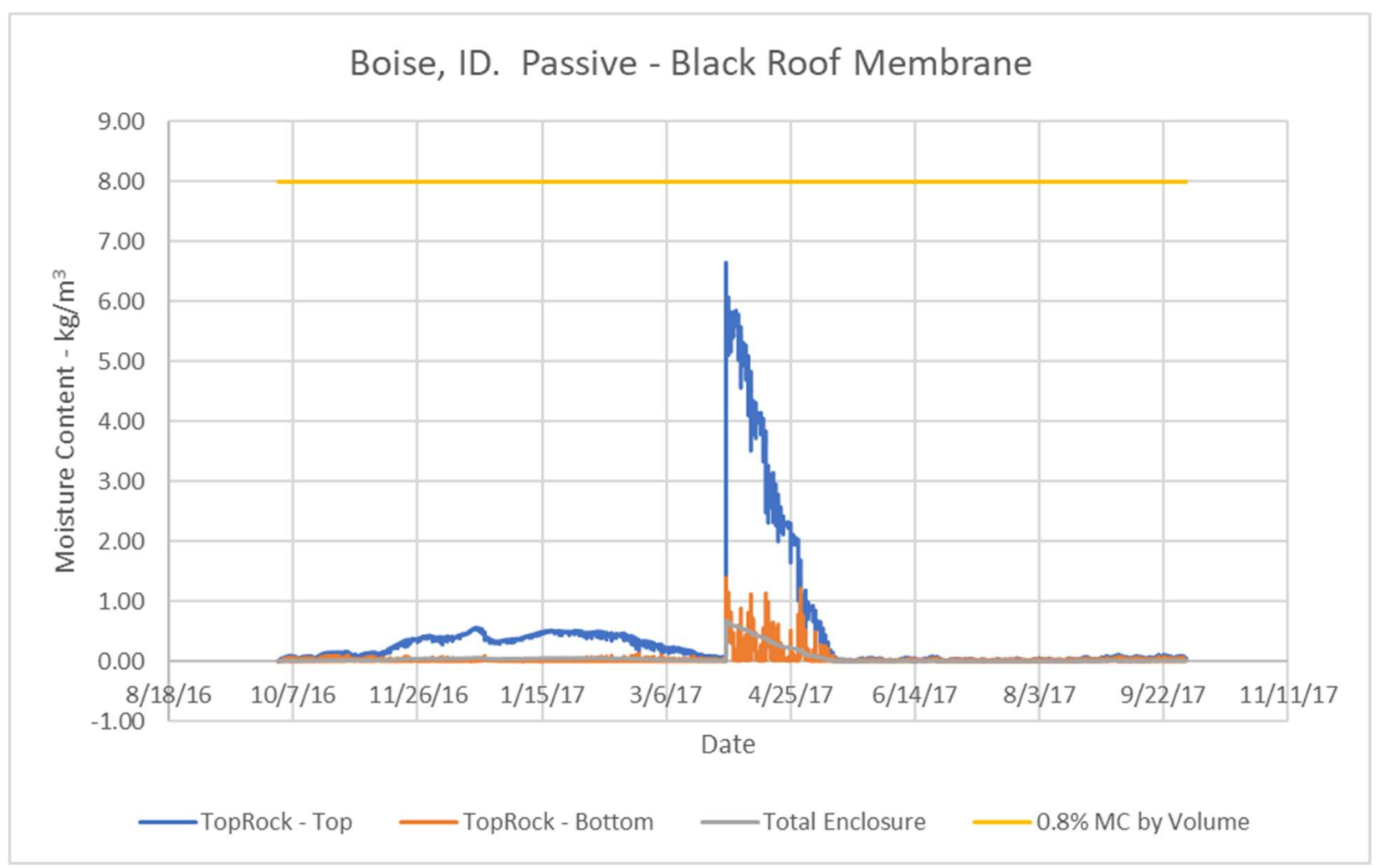



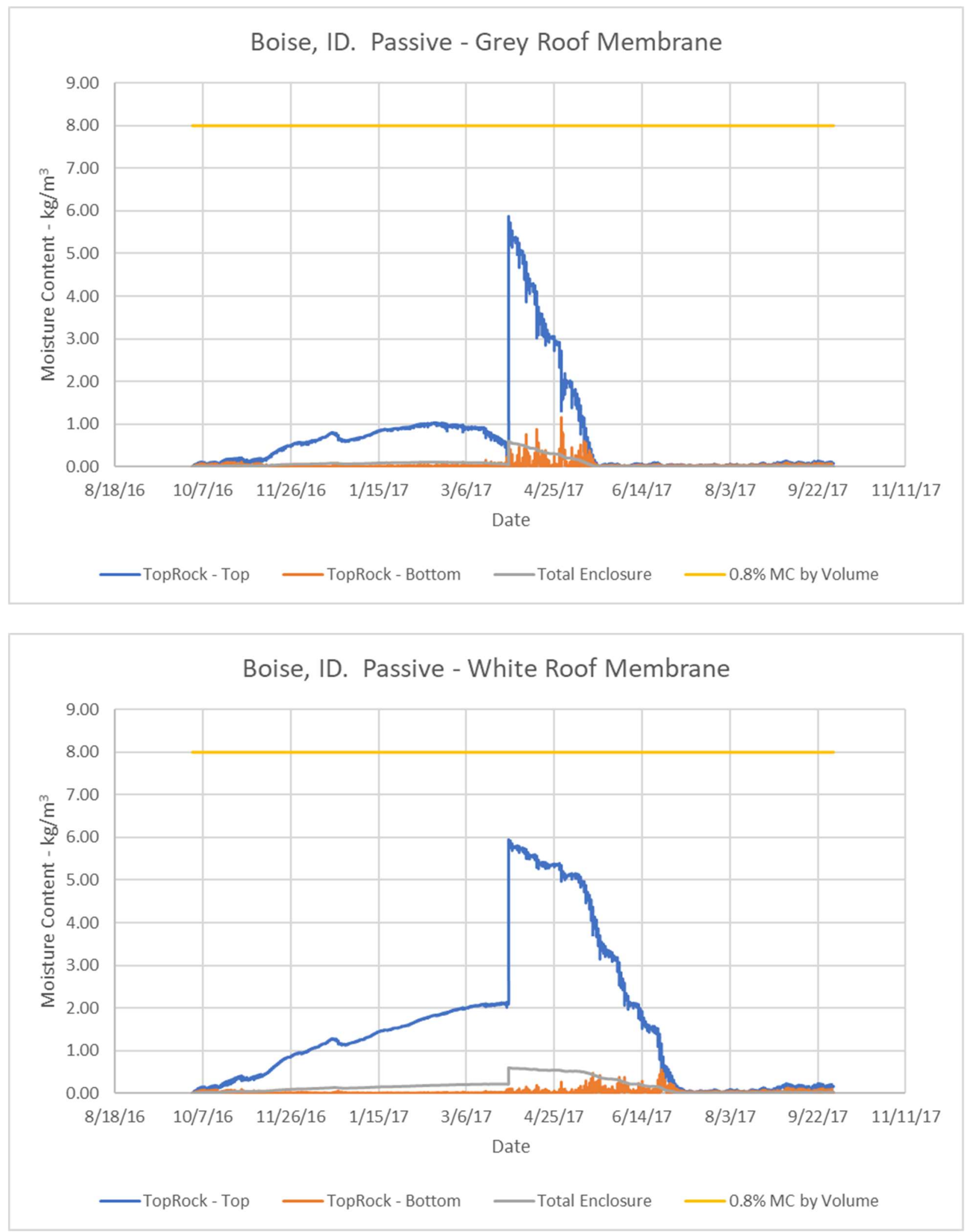
CHICAGO, IL - Passive
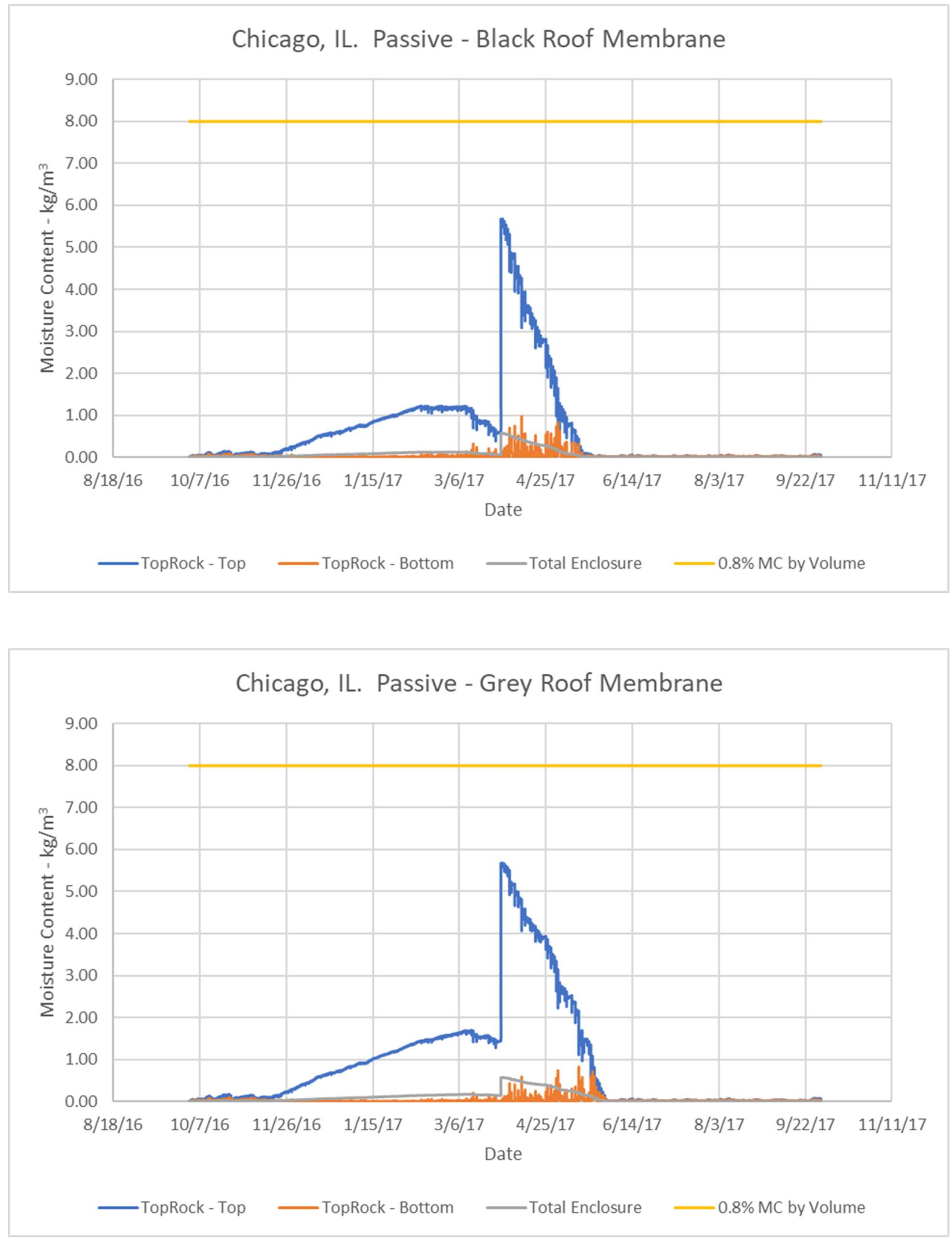


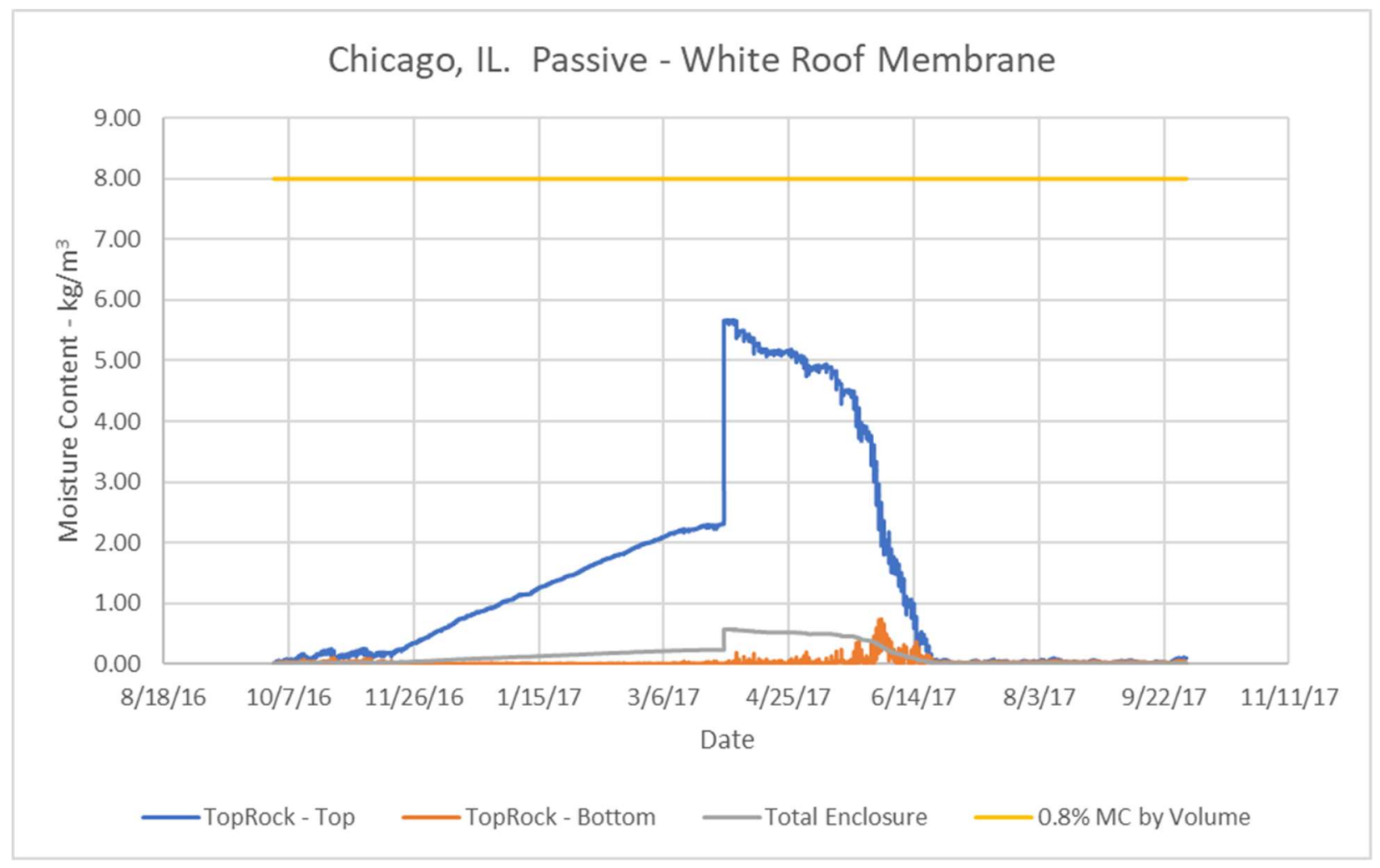

FAIRBANKS, AK - Passive

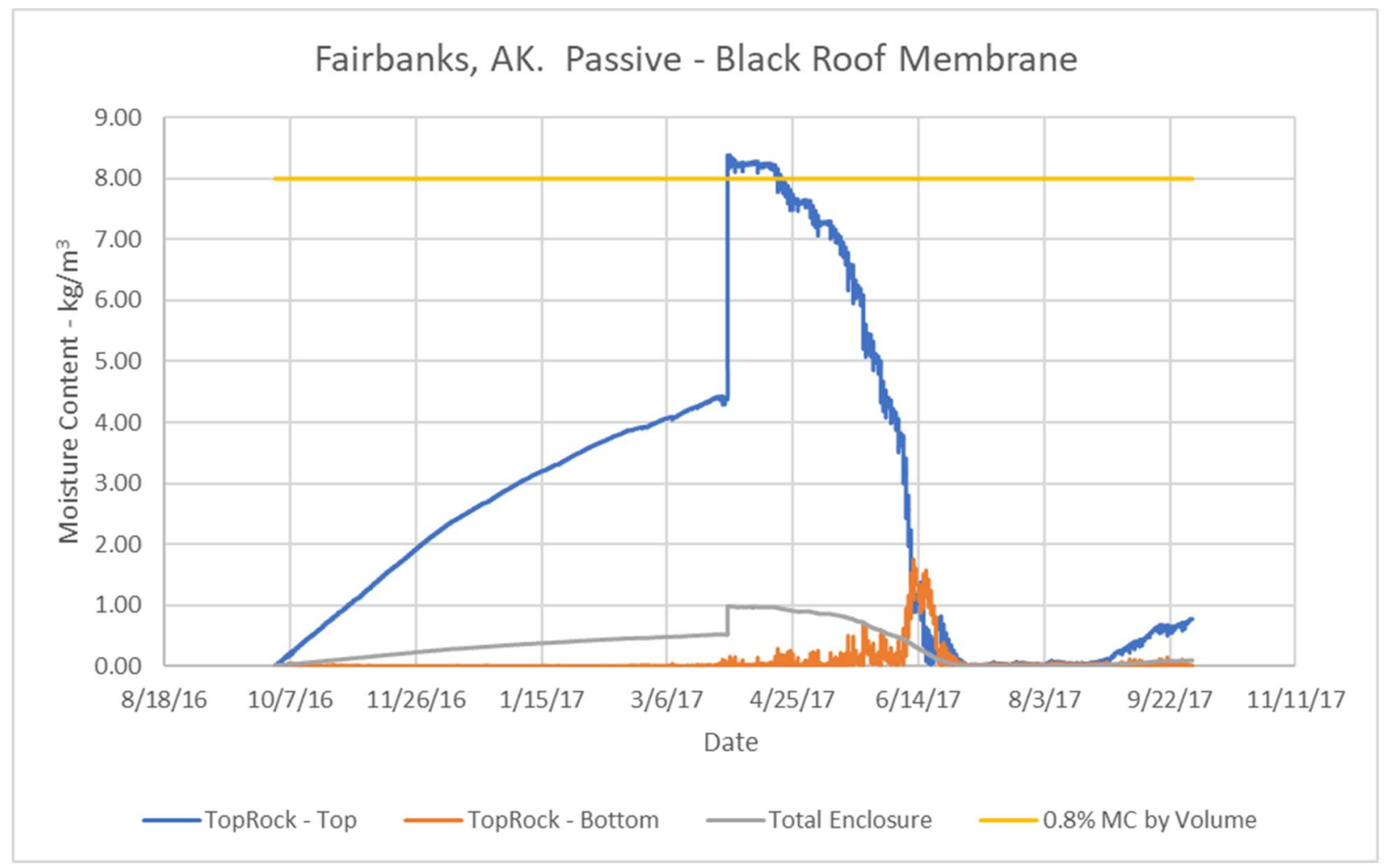



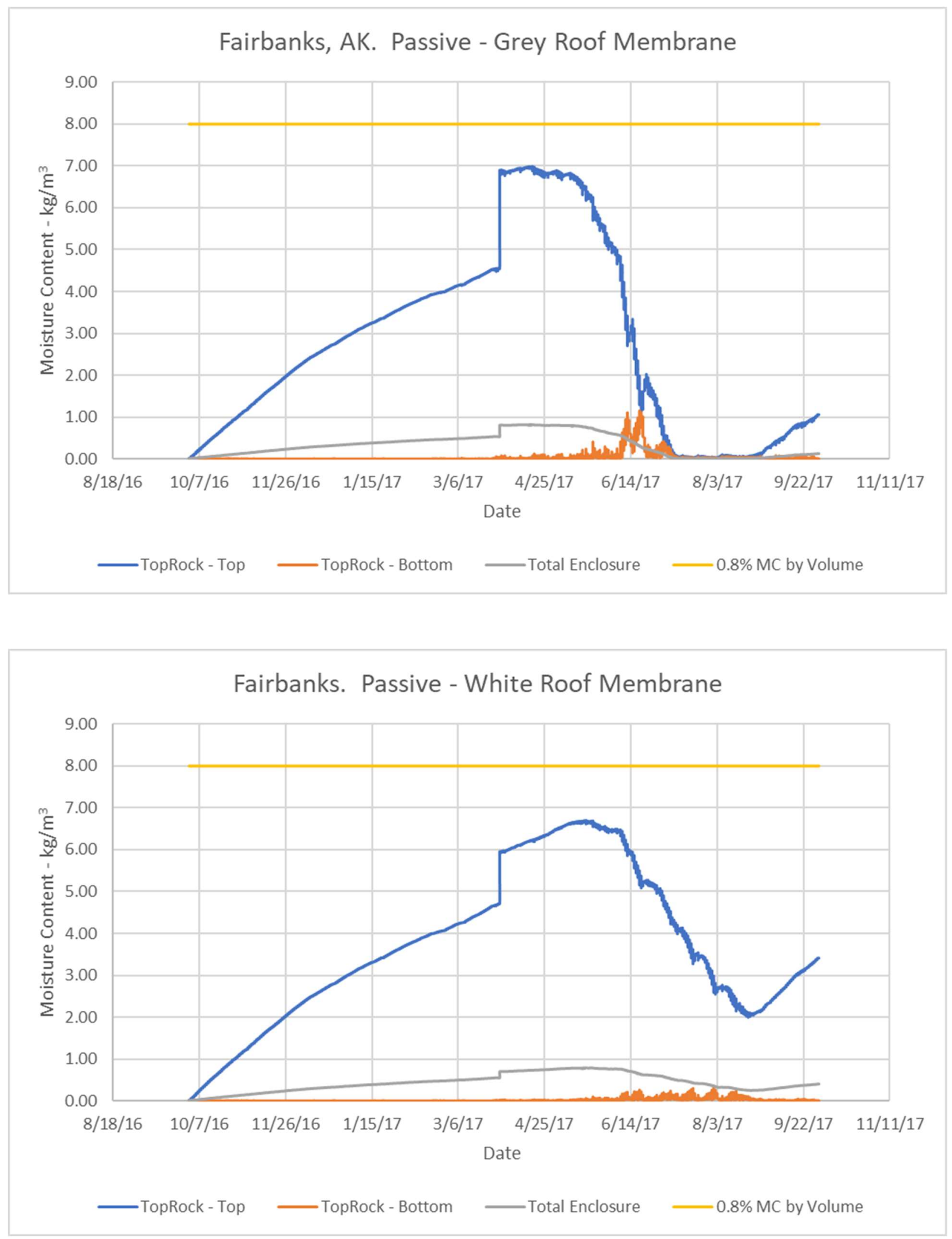

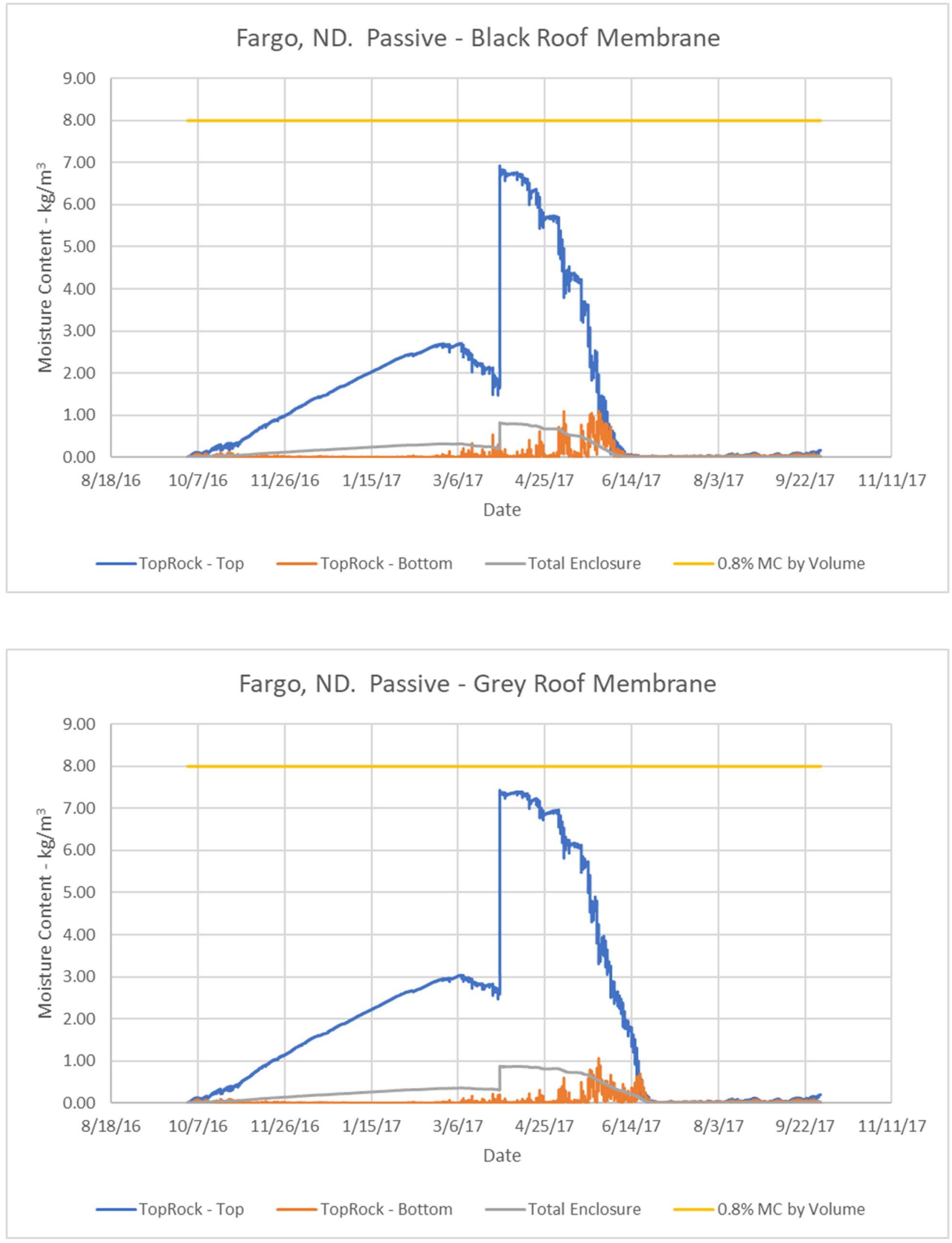


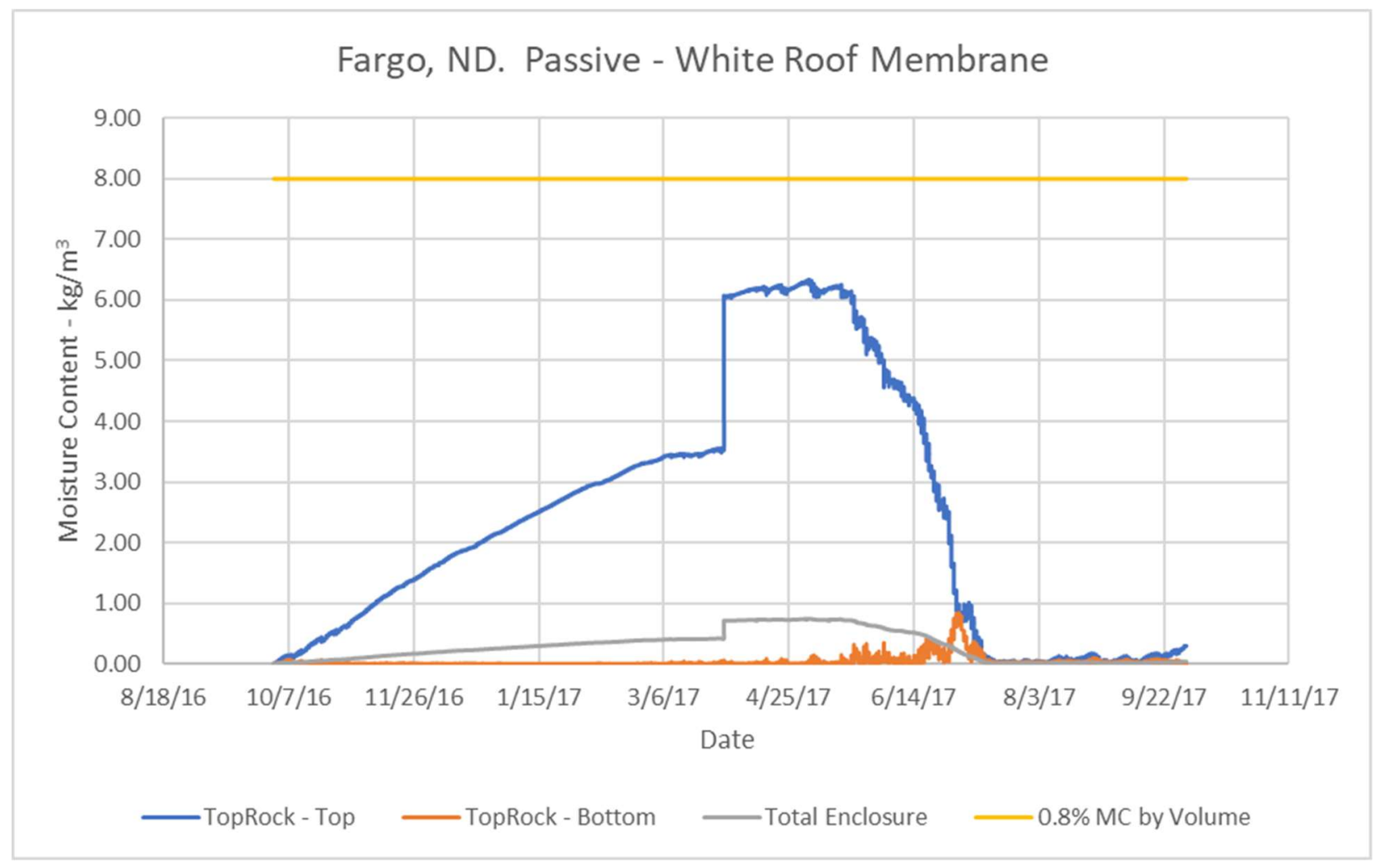

\section{HOUSTON, TX - Passive}

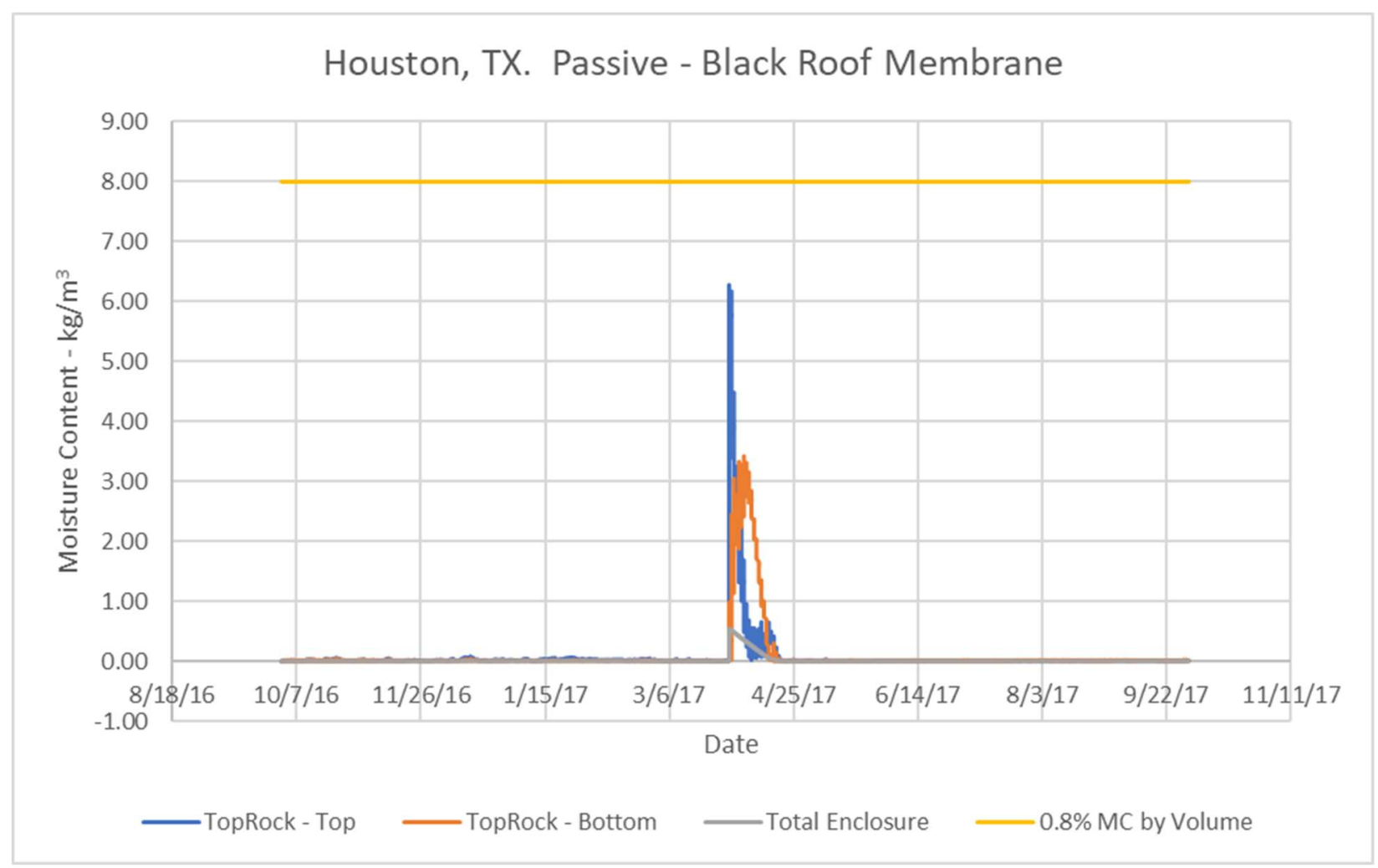



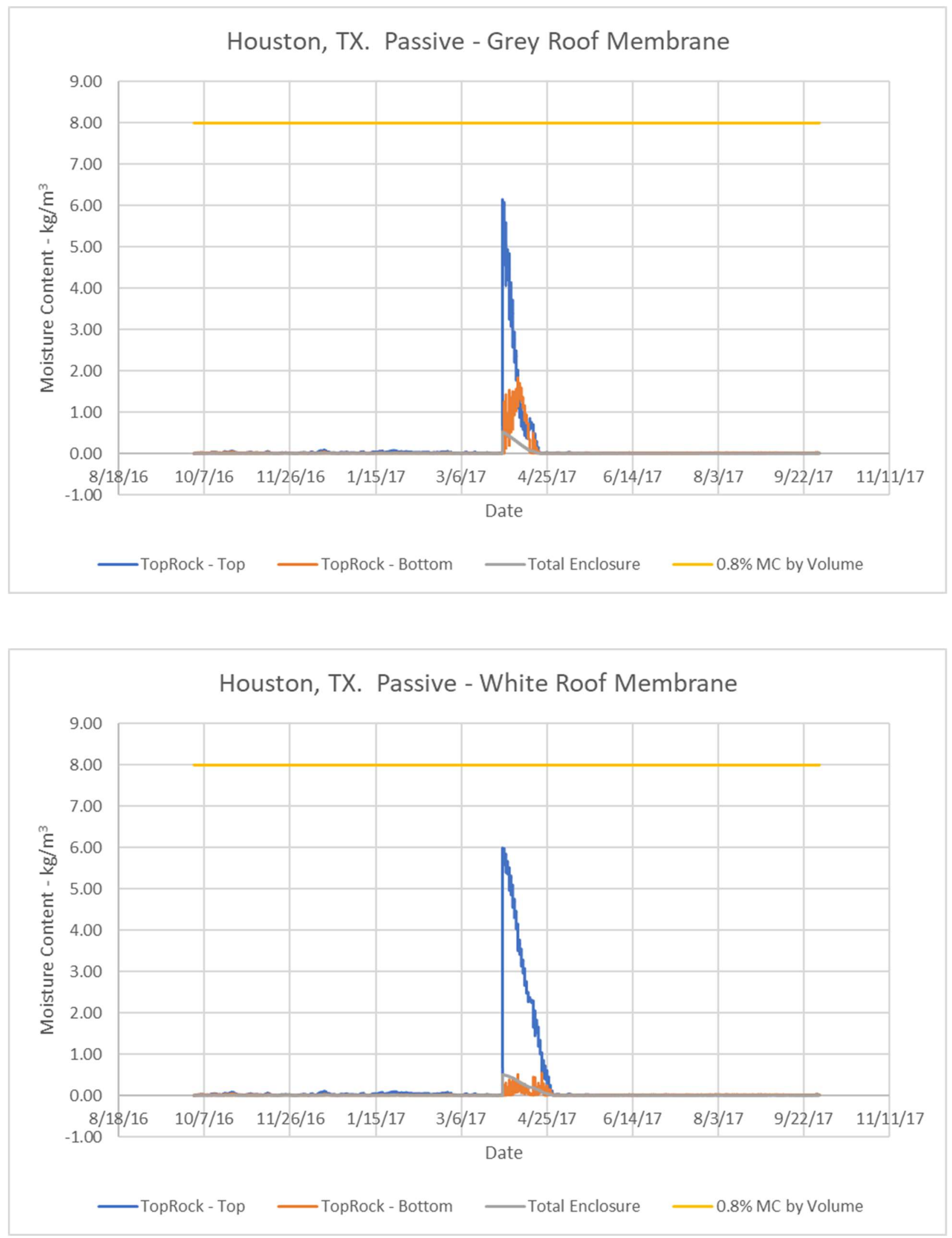

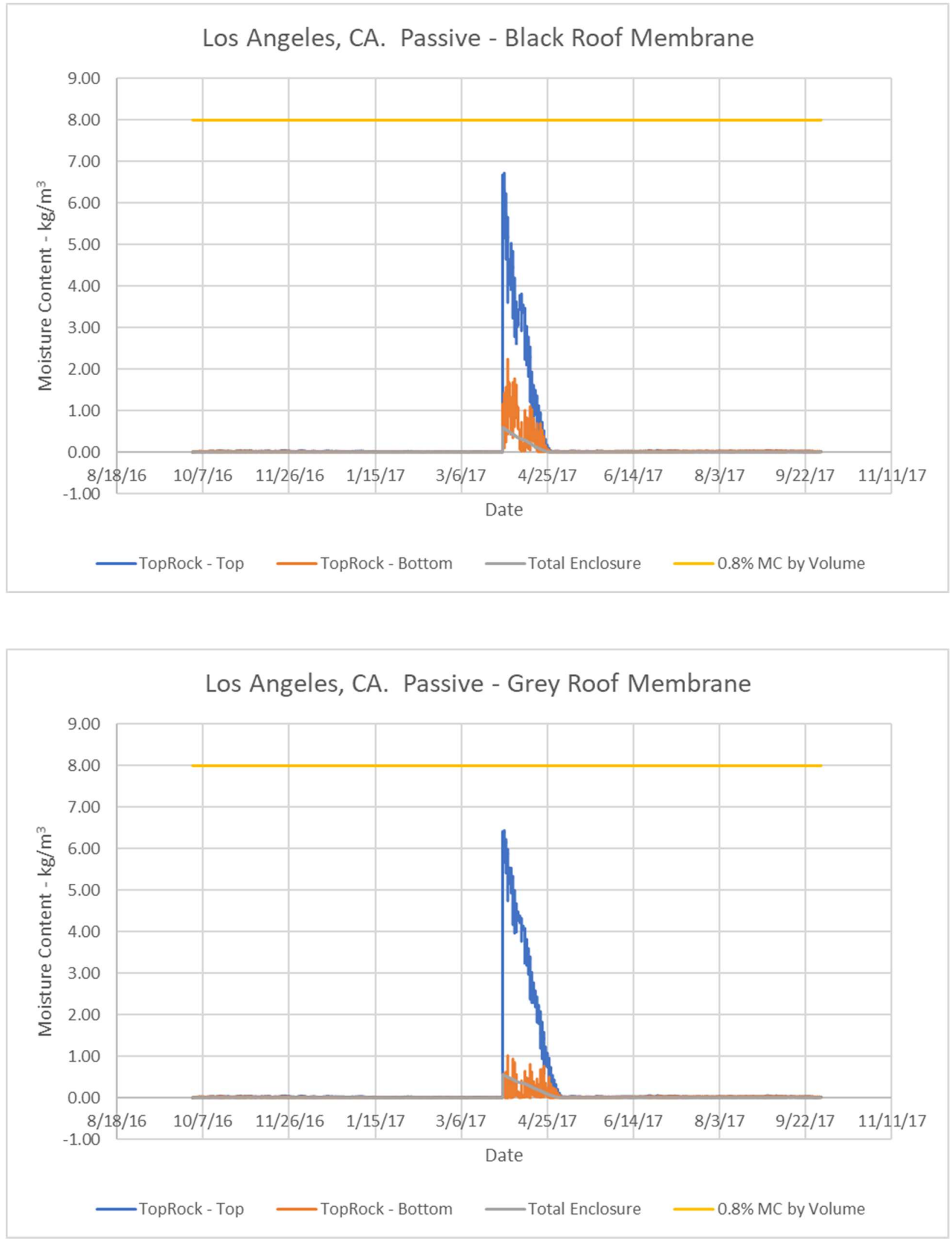


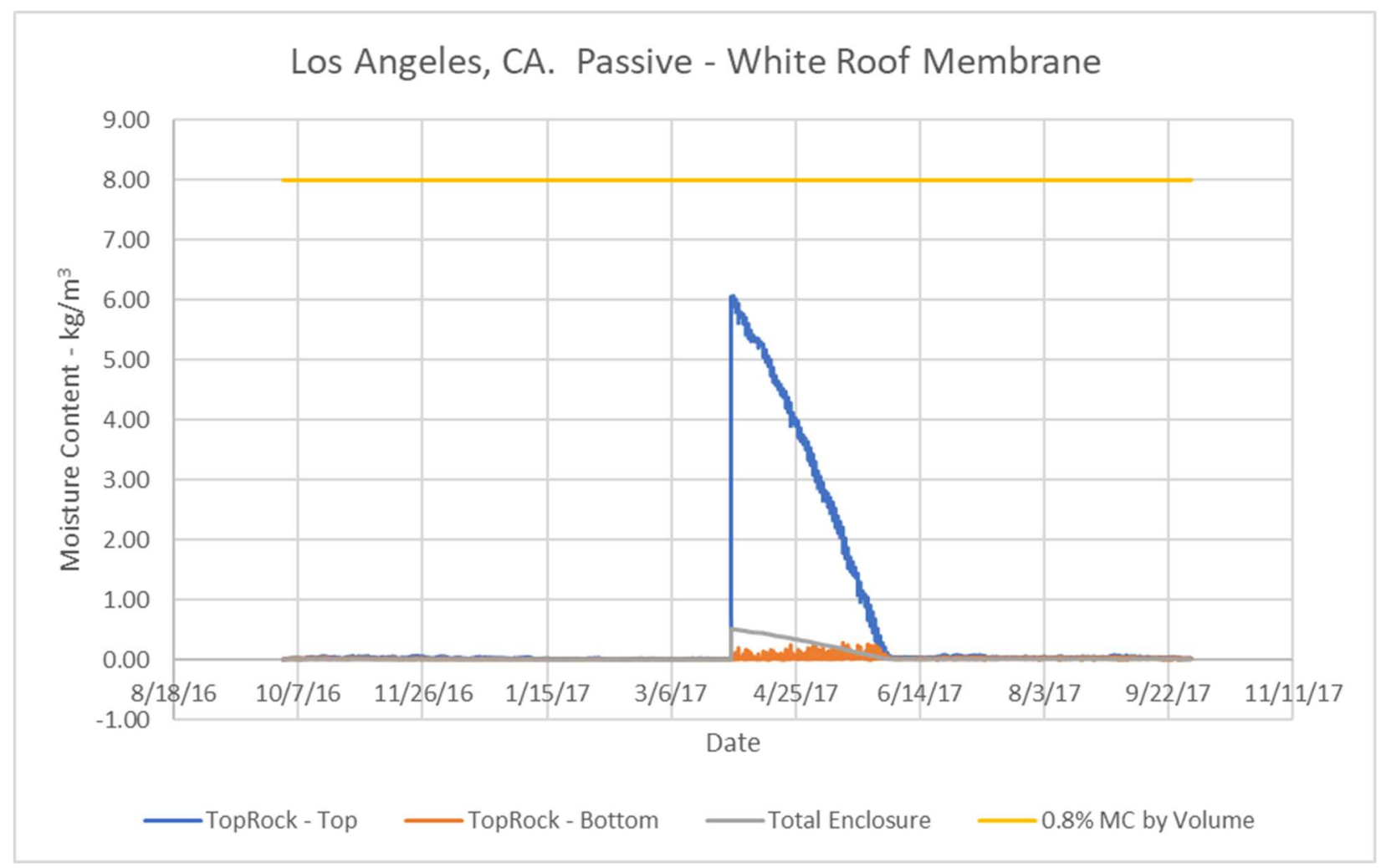

MIAMI, FL - Passive

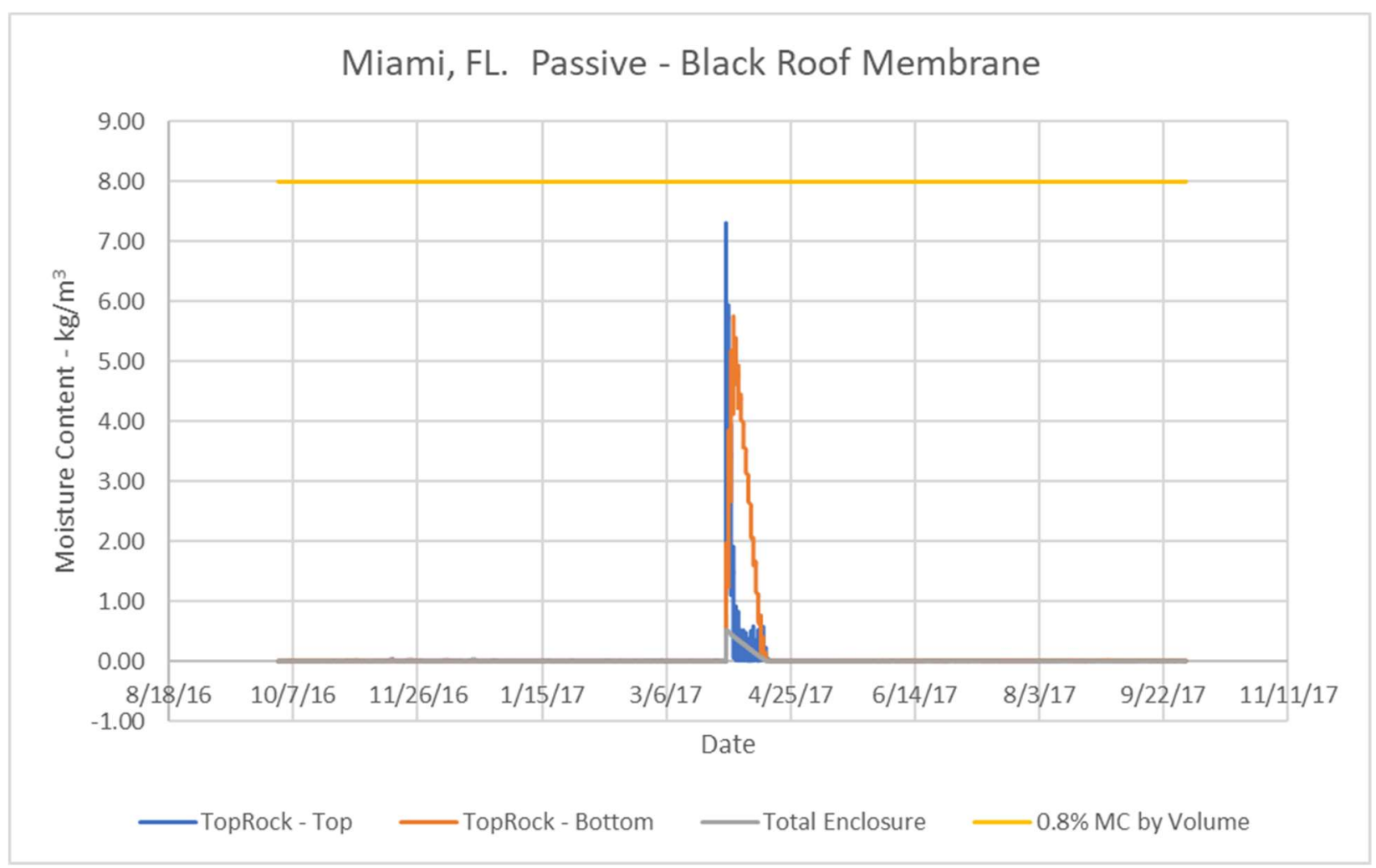



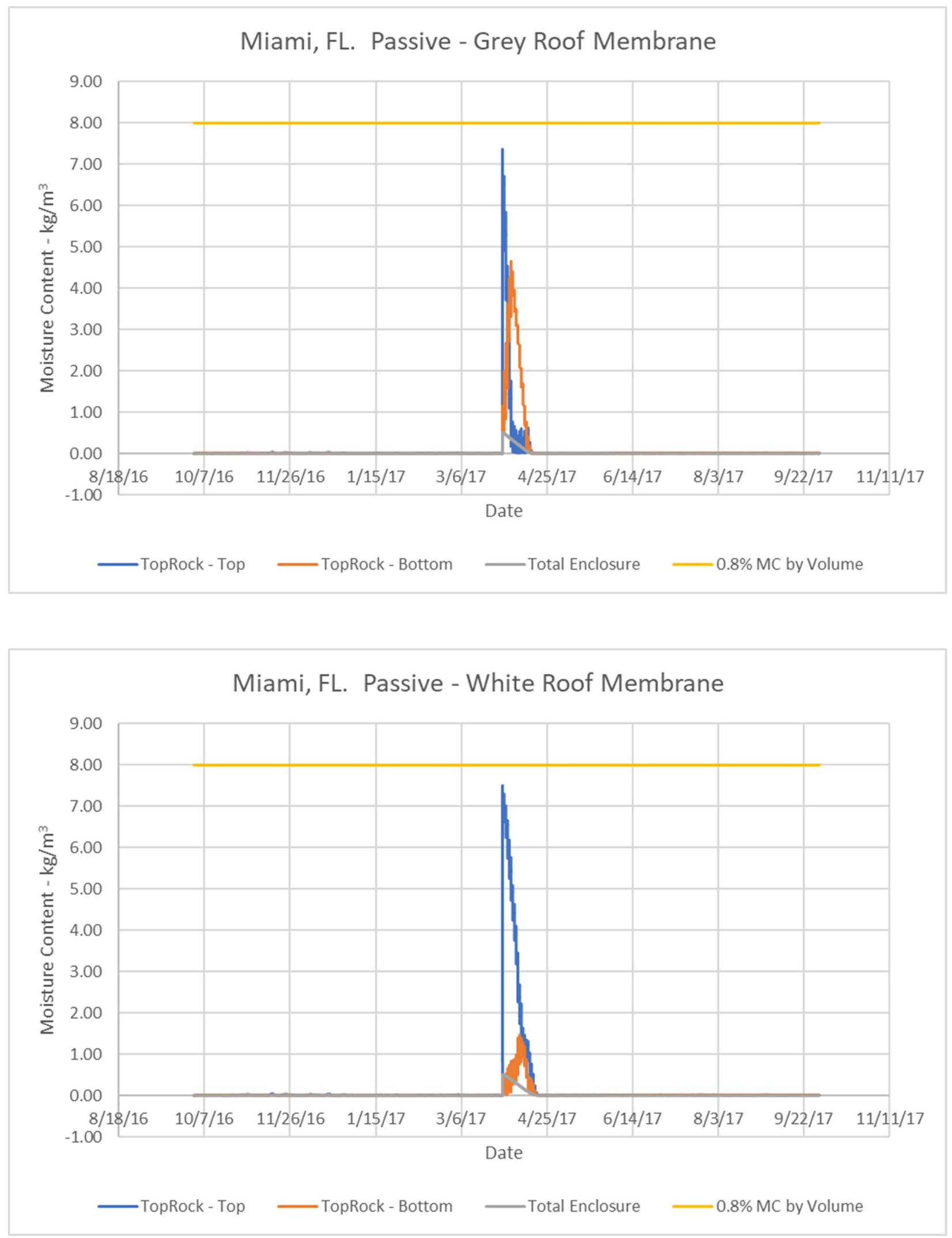

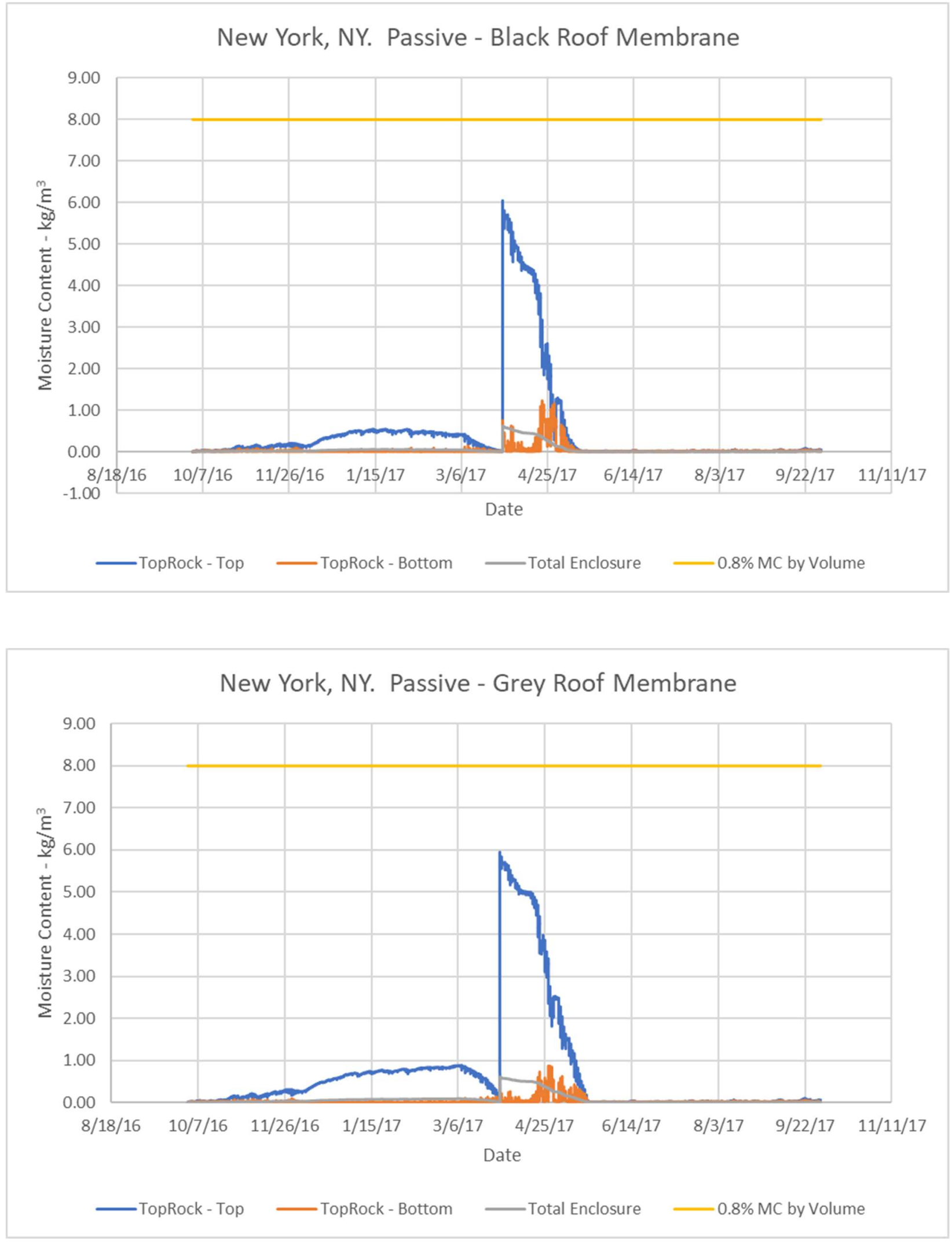


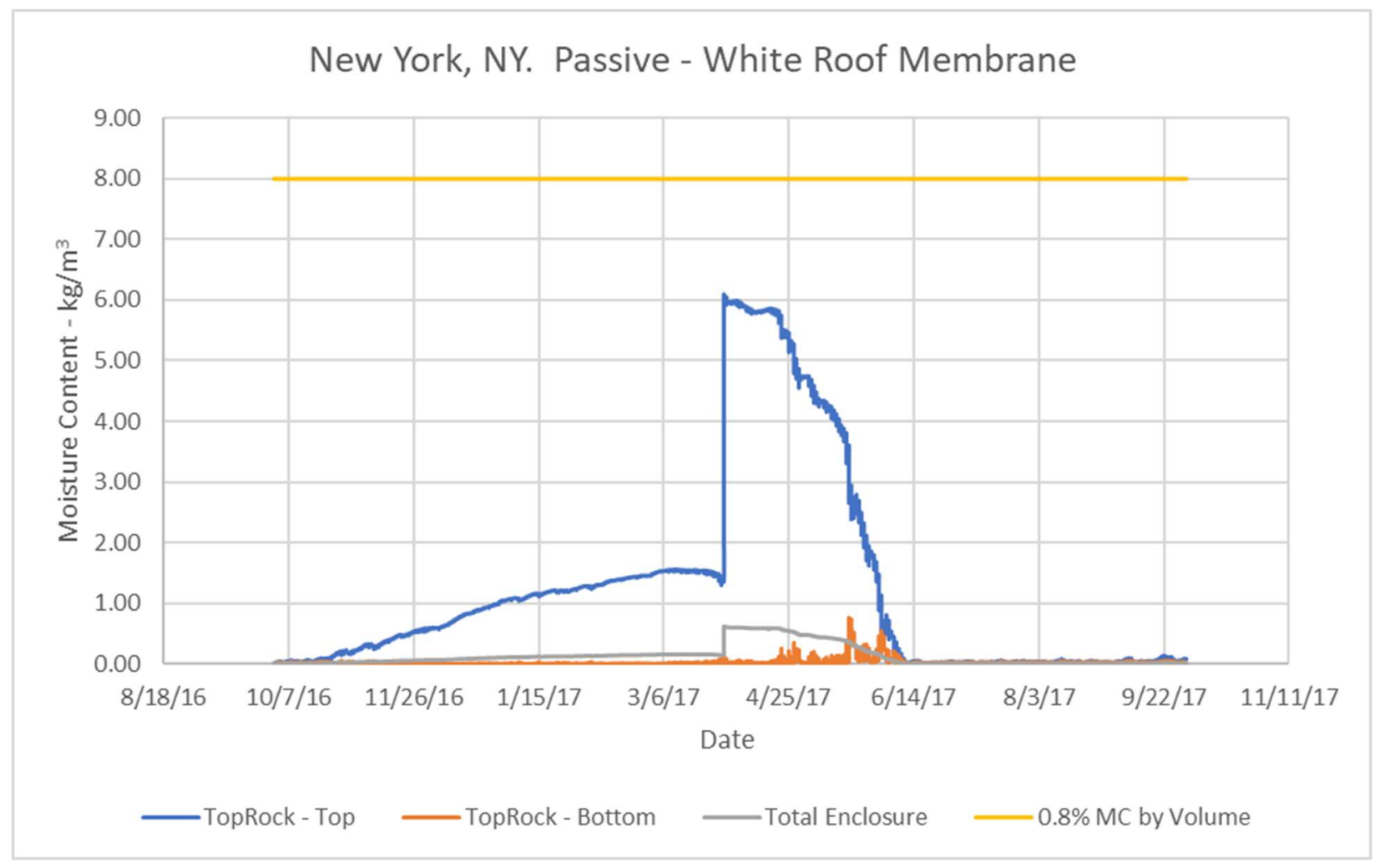

\section{EDMONTON, AB - Active}

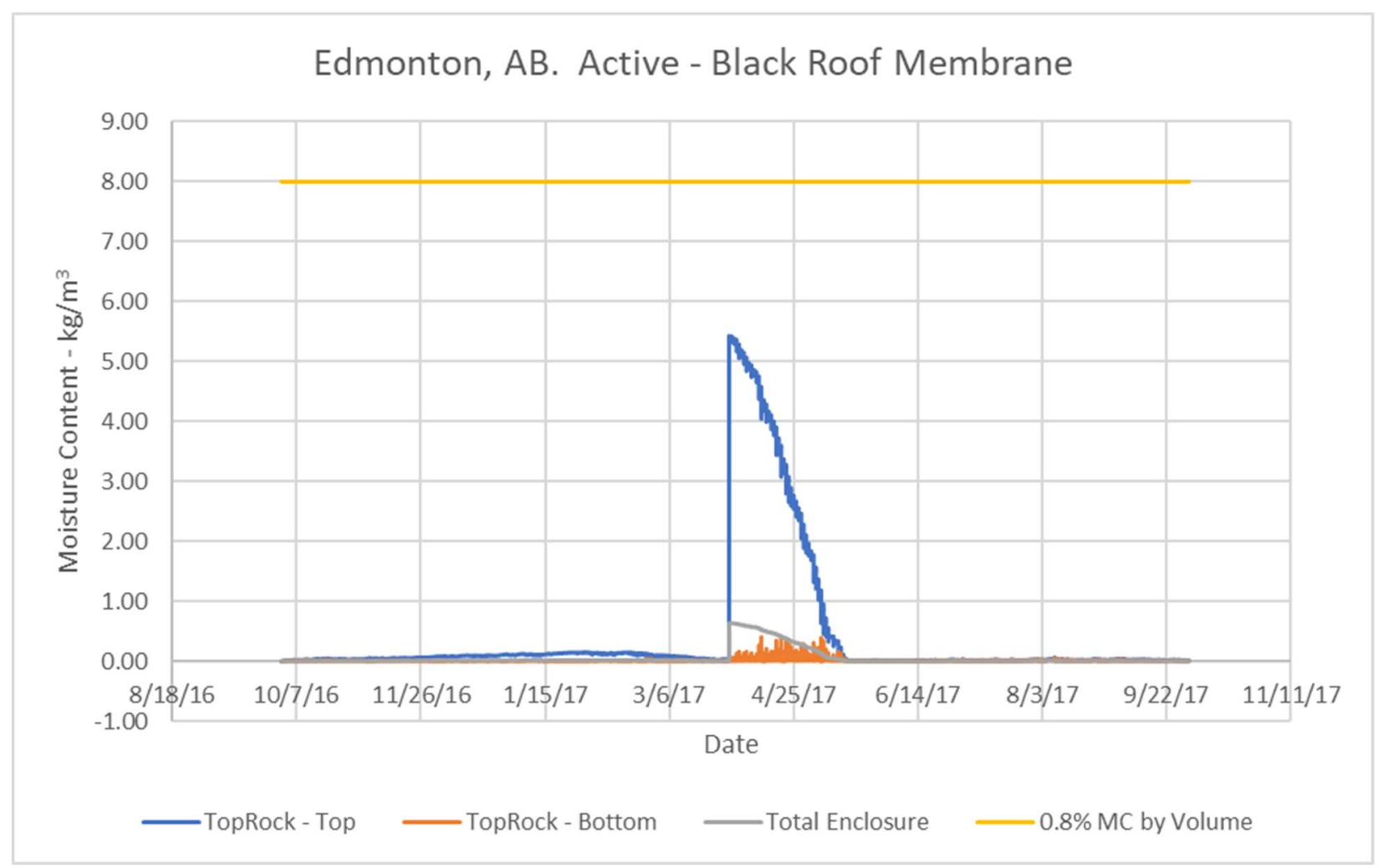



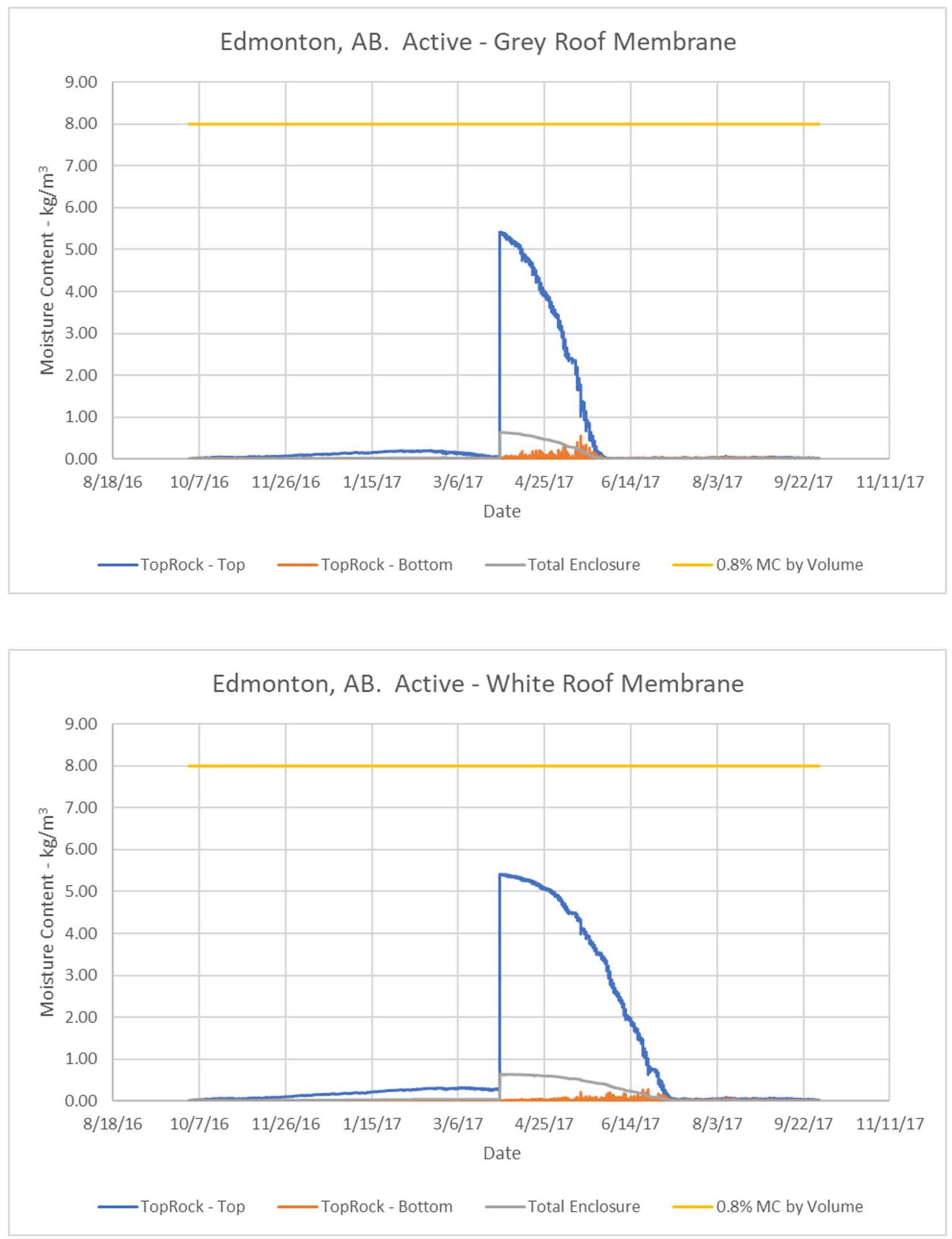




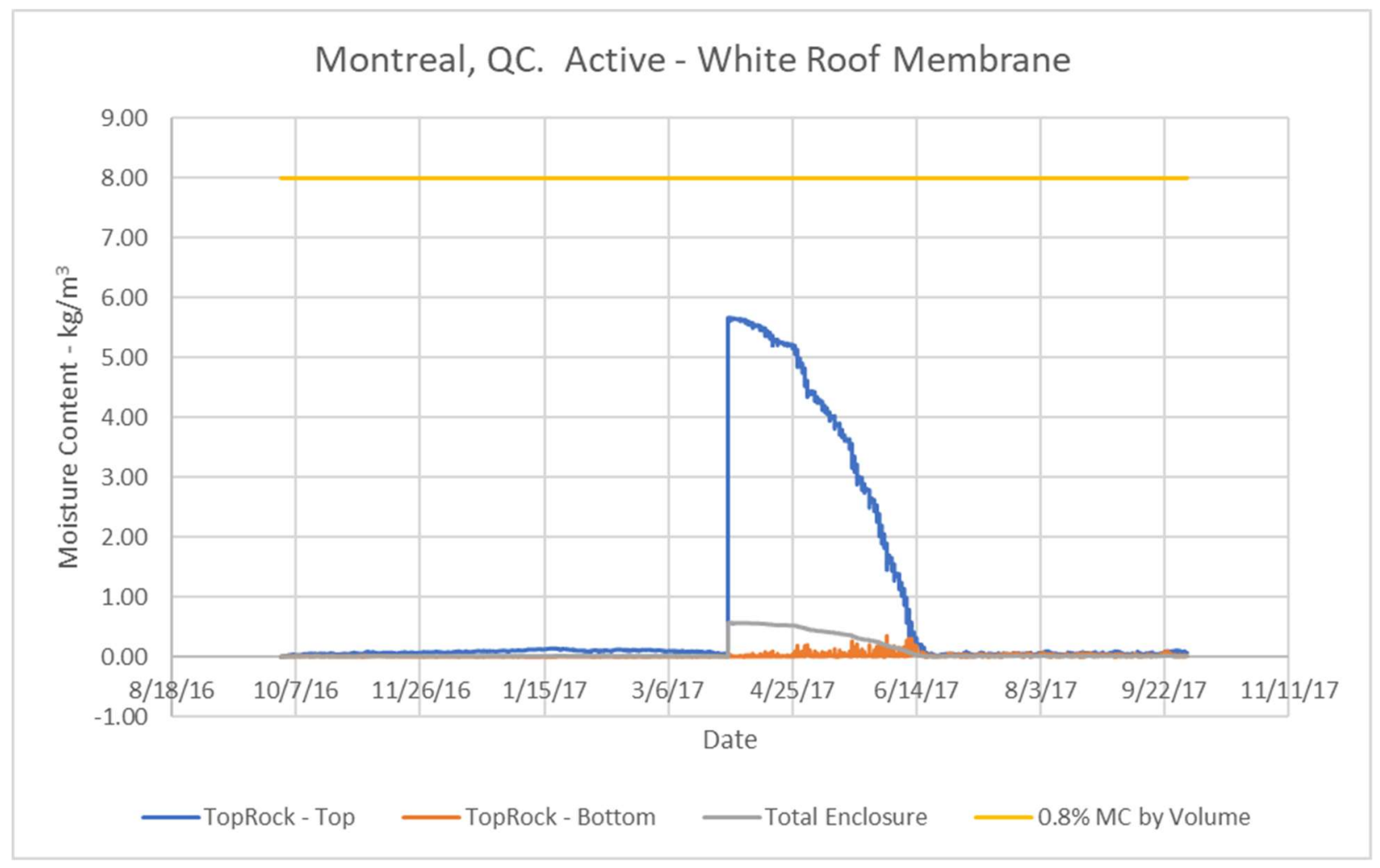

\section{ST. JOHN'S - Active}

St. John's, NFLD. Active - Black Roof Membrane

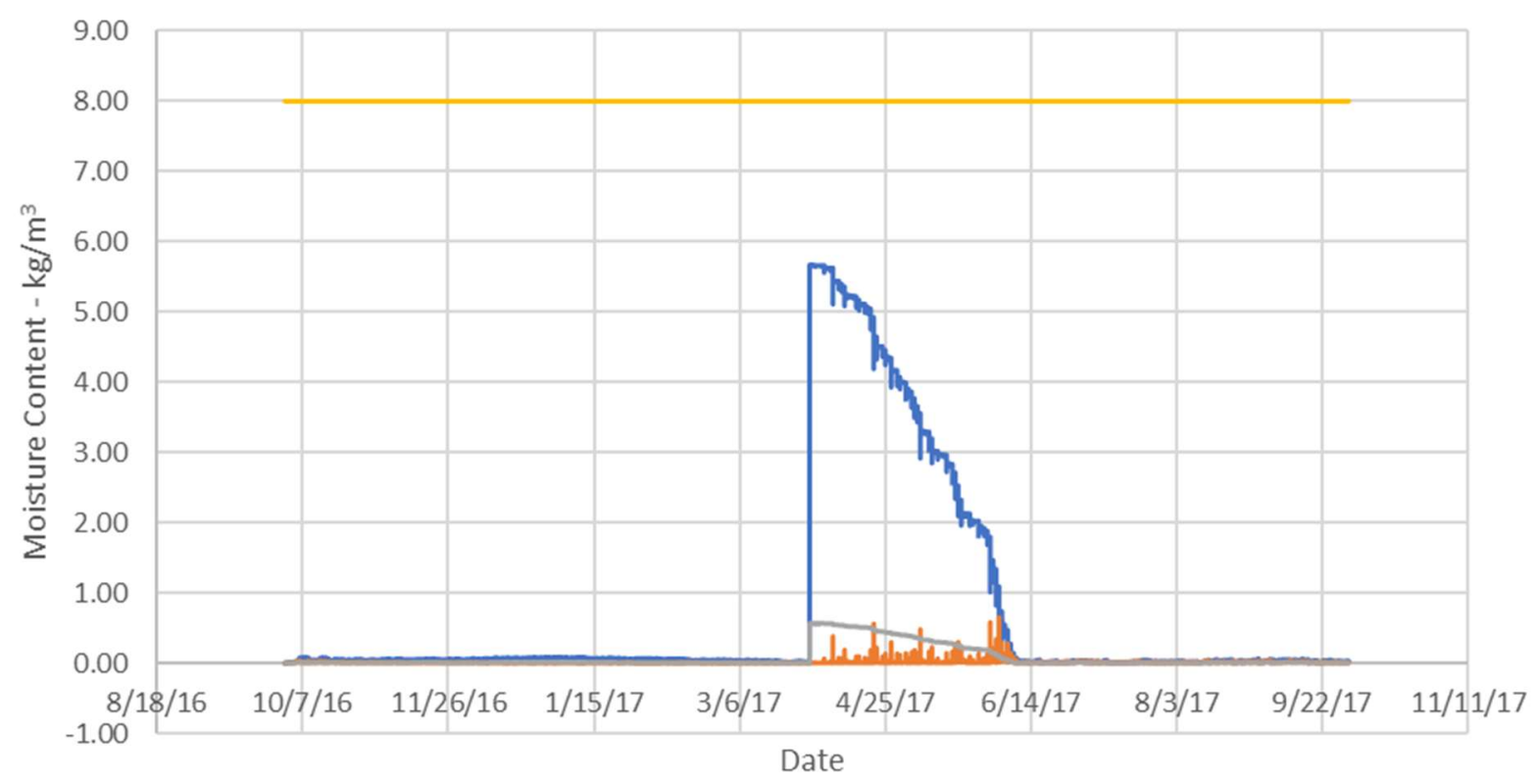

-TopRock - Top — TopRock - Bottom - Total Enclosure $\quad-0.8 \%$ MC by Volume 

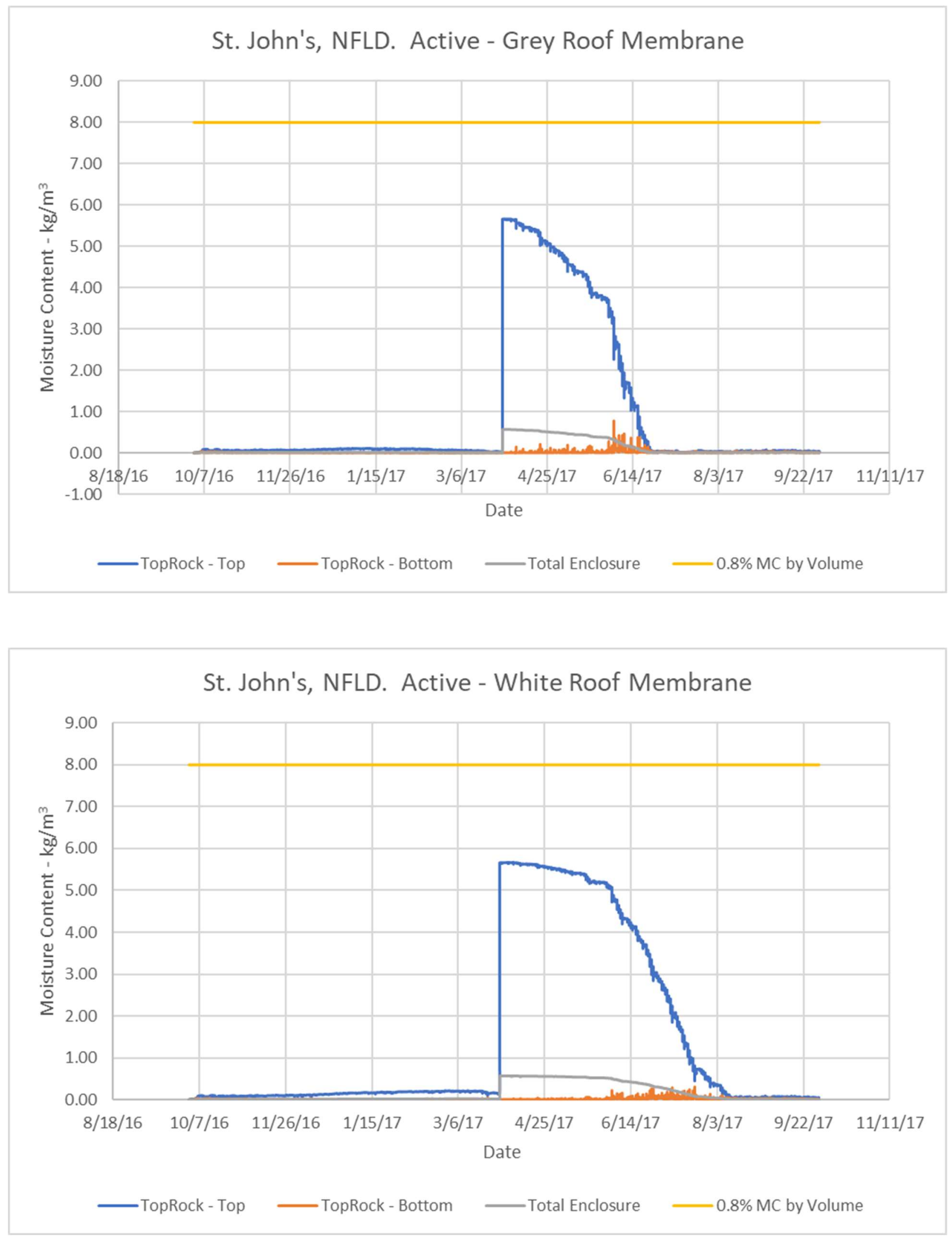
TORONTO, ON - Active
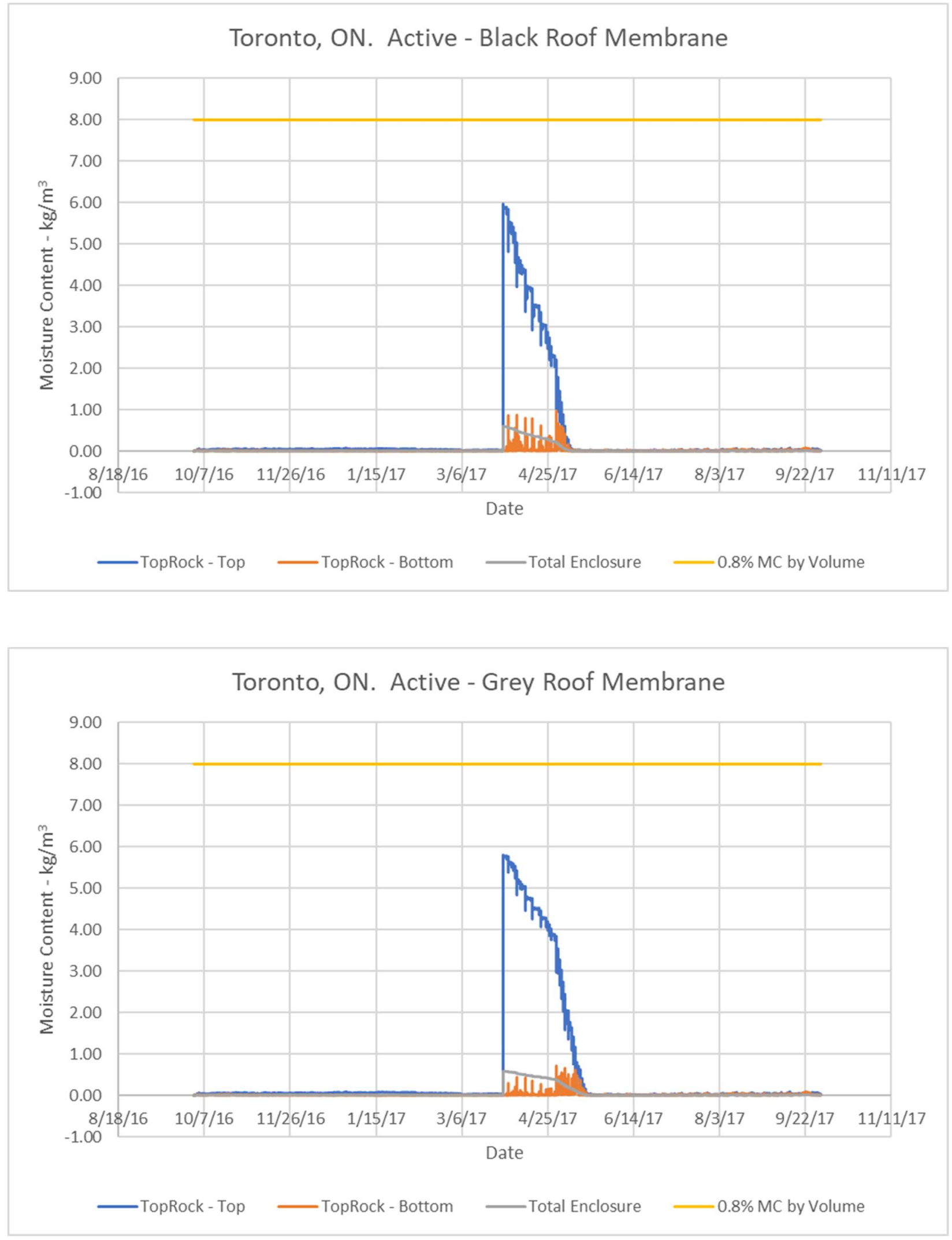


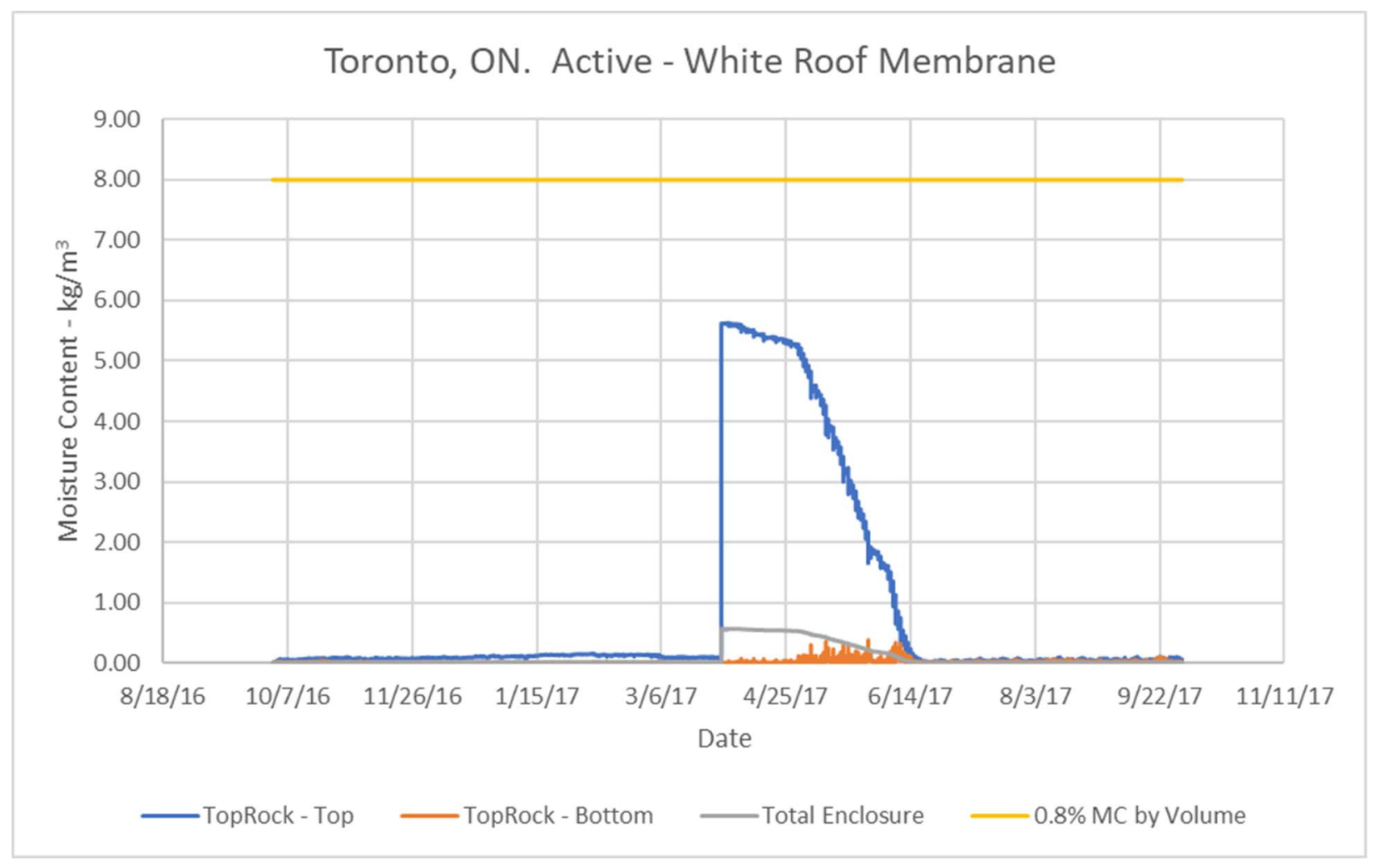

Vancouver, BC-Active

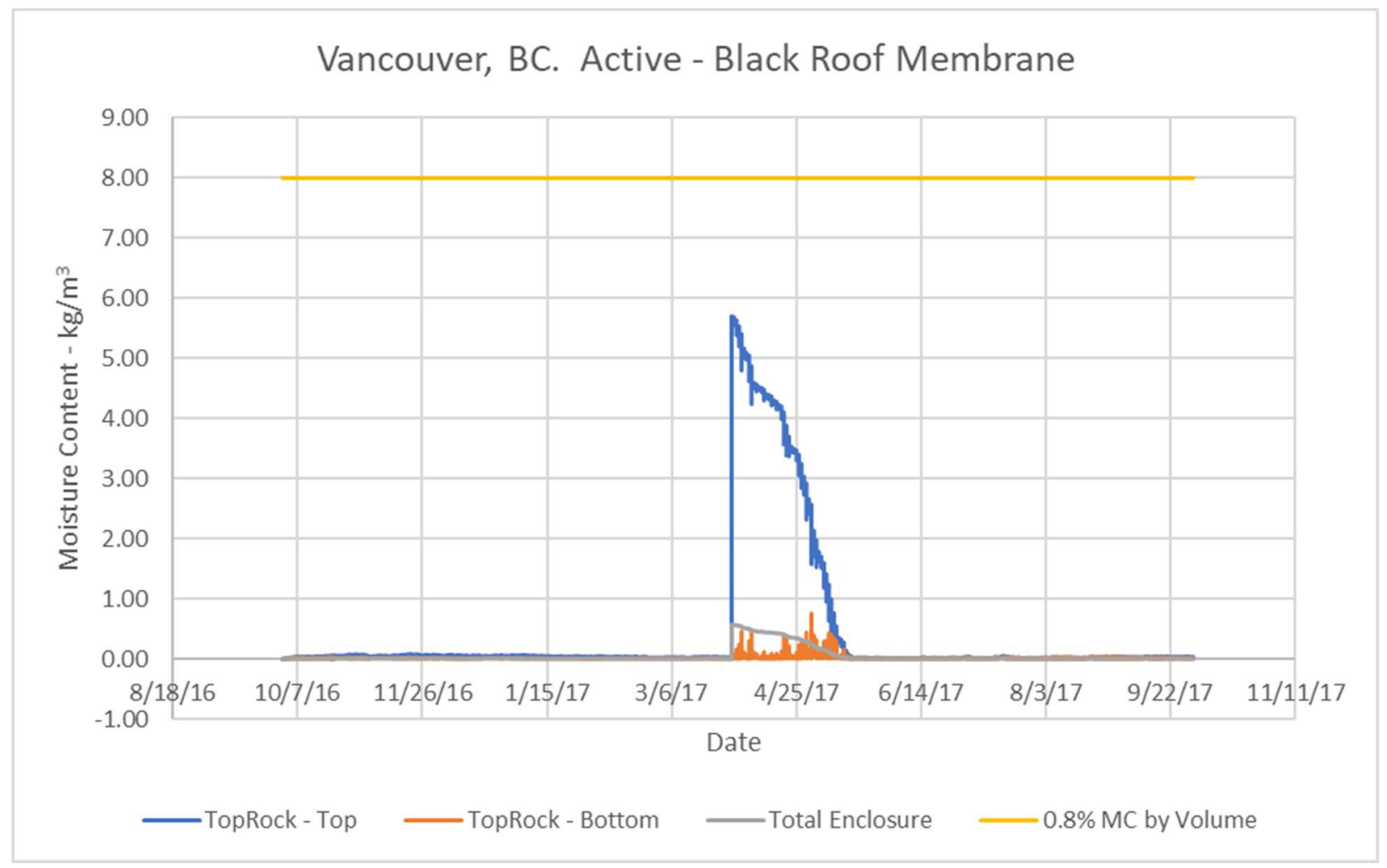



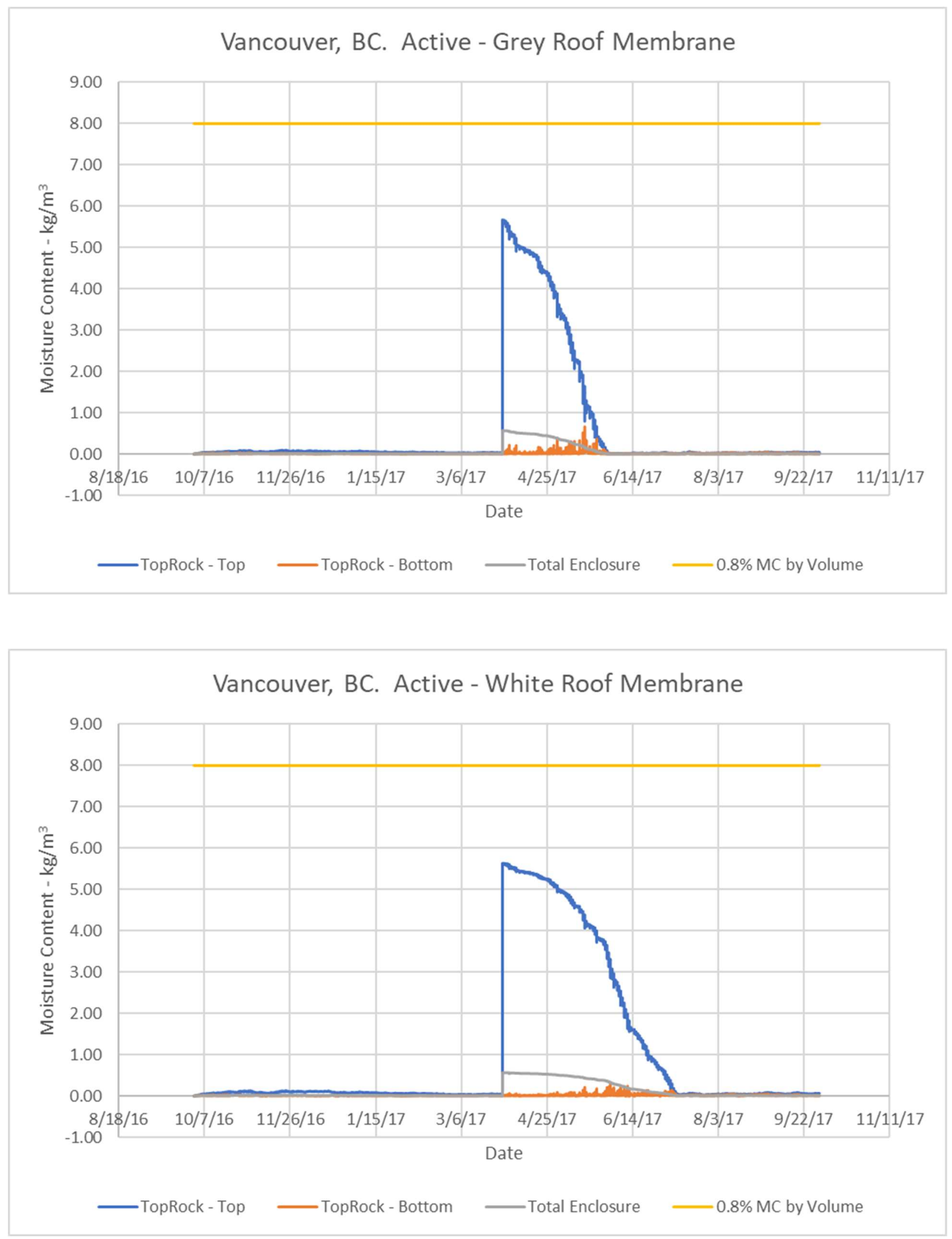

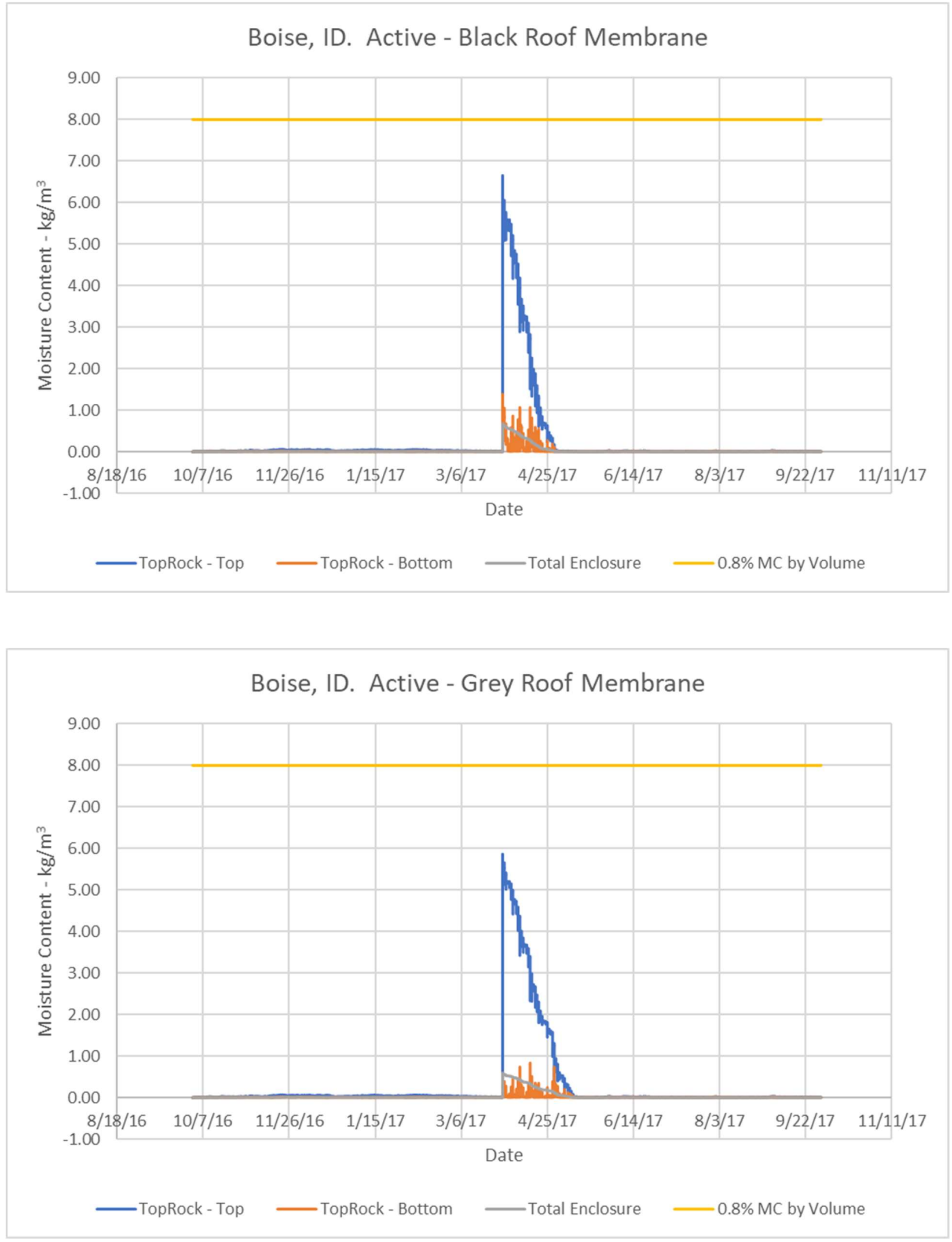


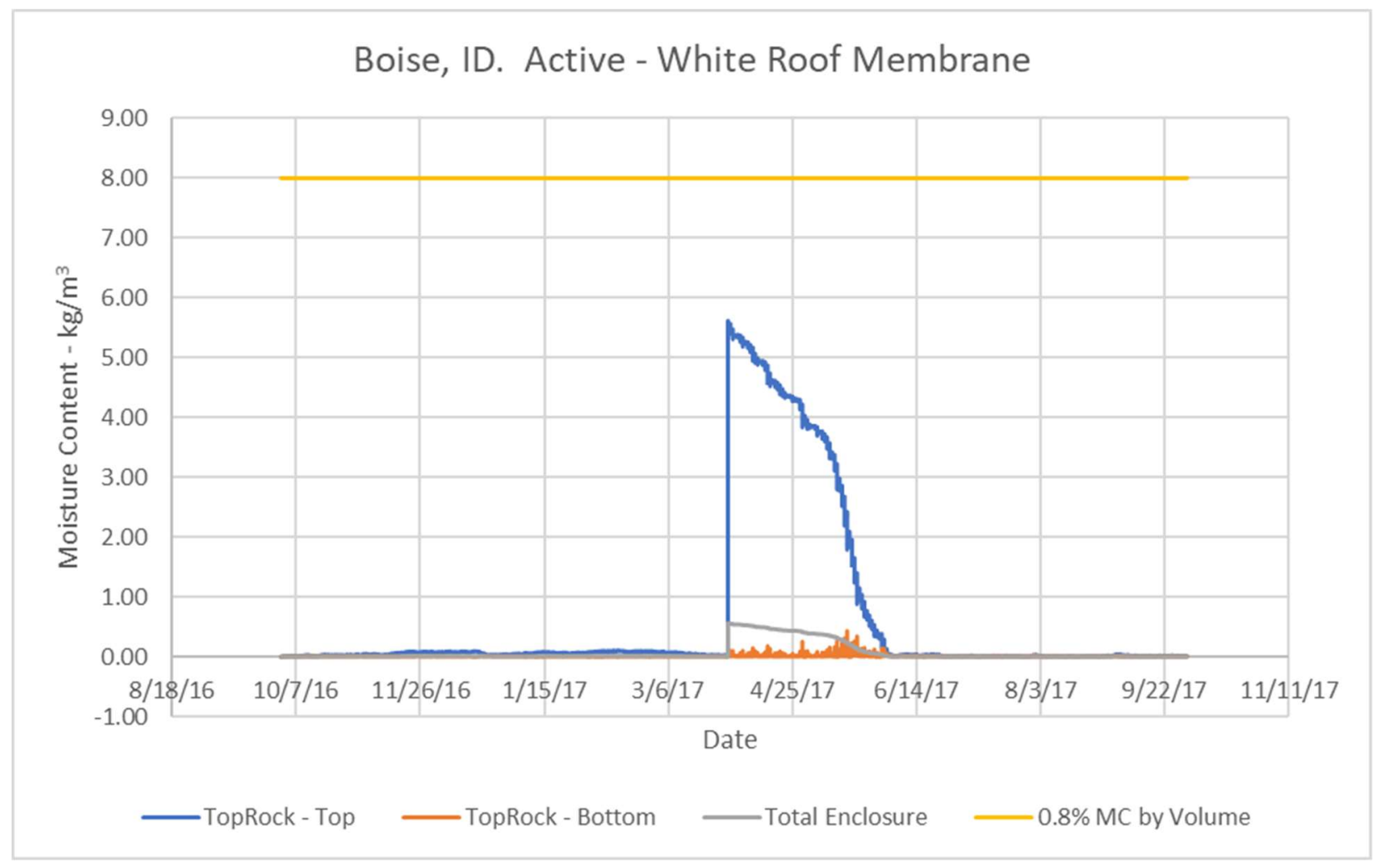

\section{Chicago, IL - Active}

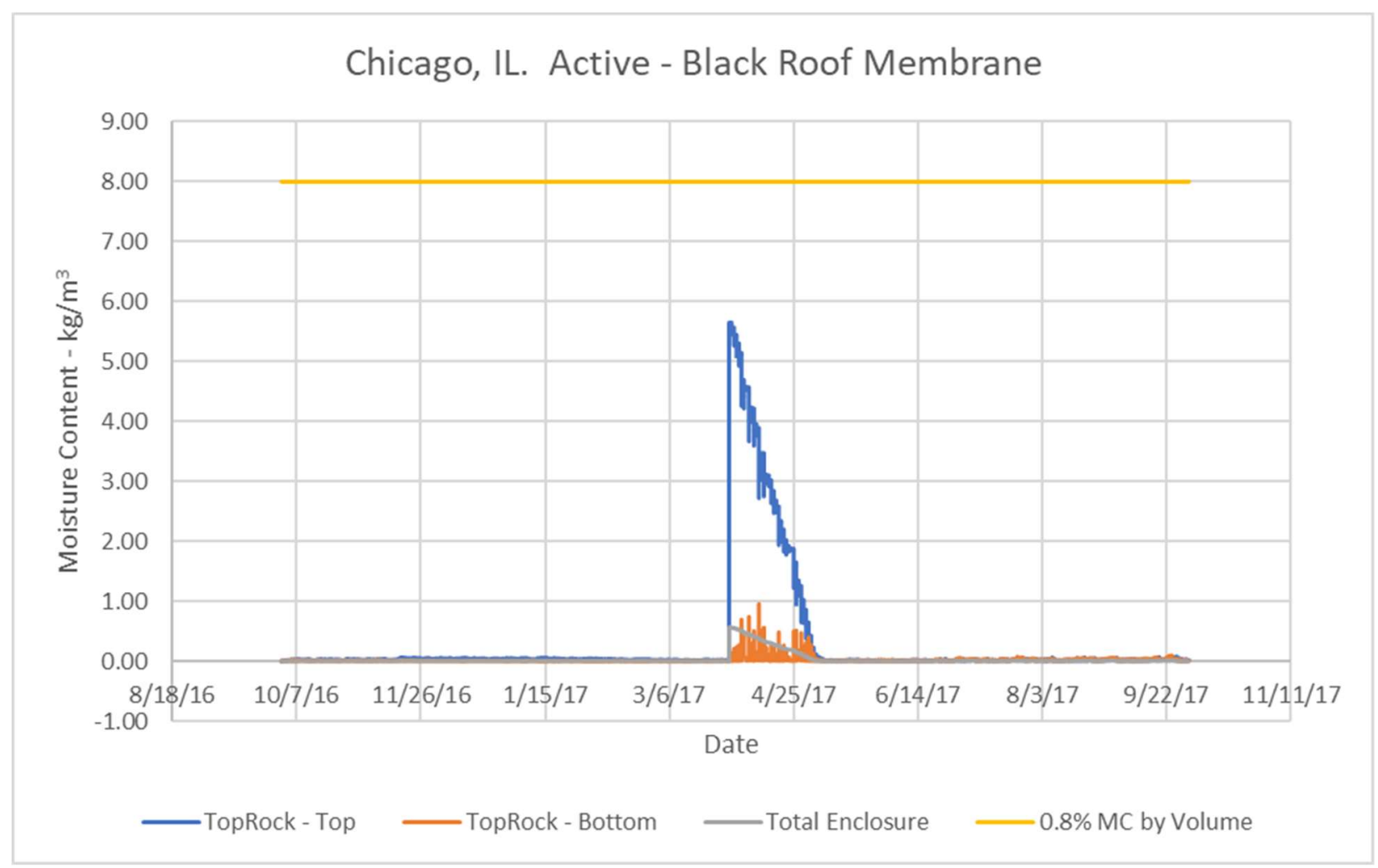



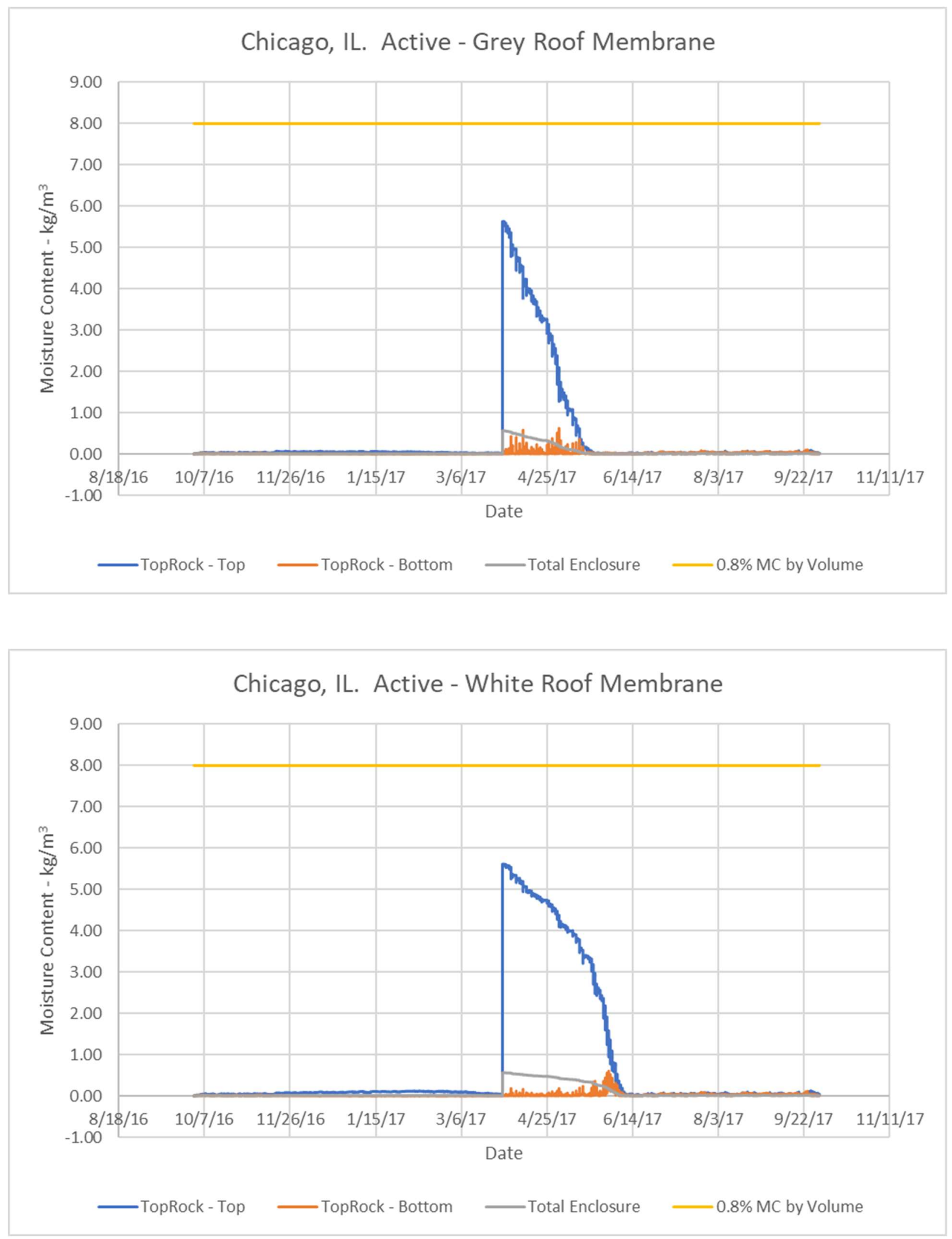

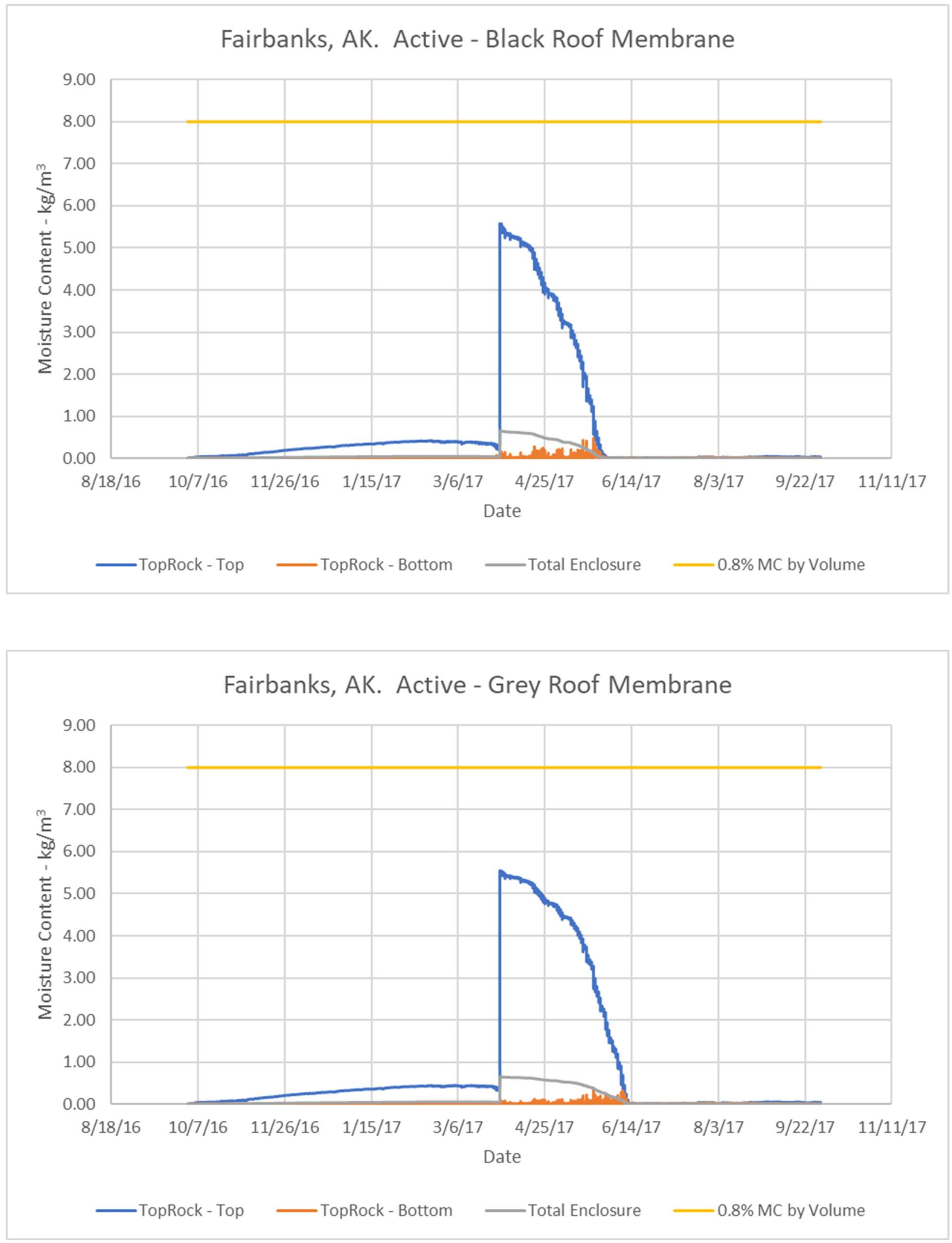


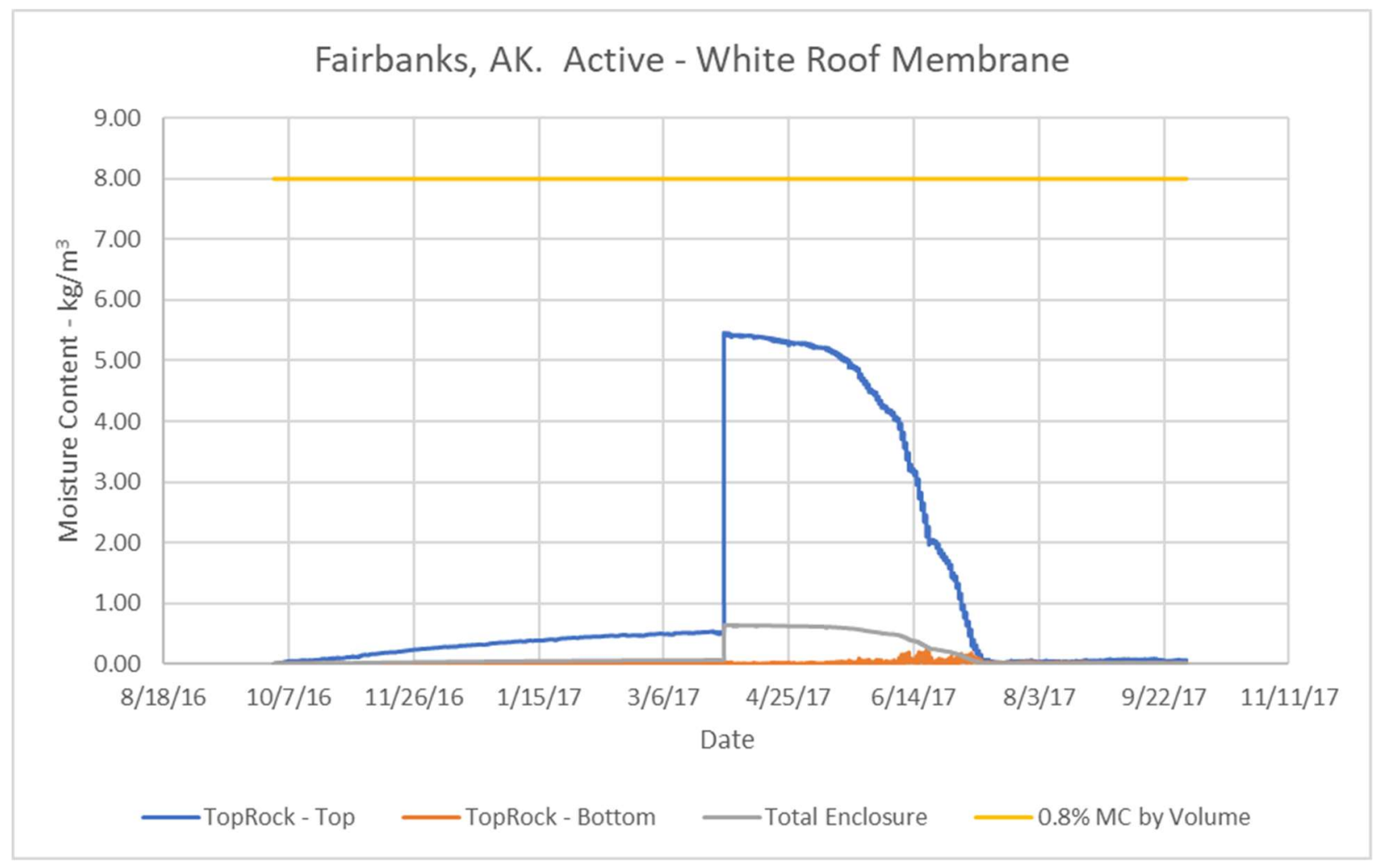

FARGO, ND - Active

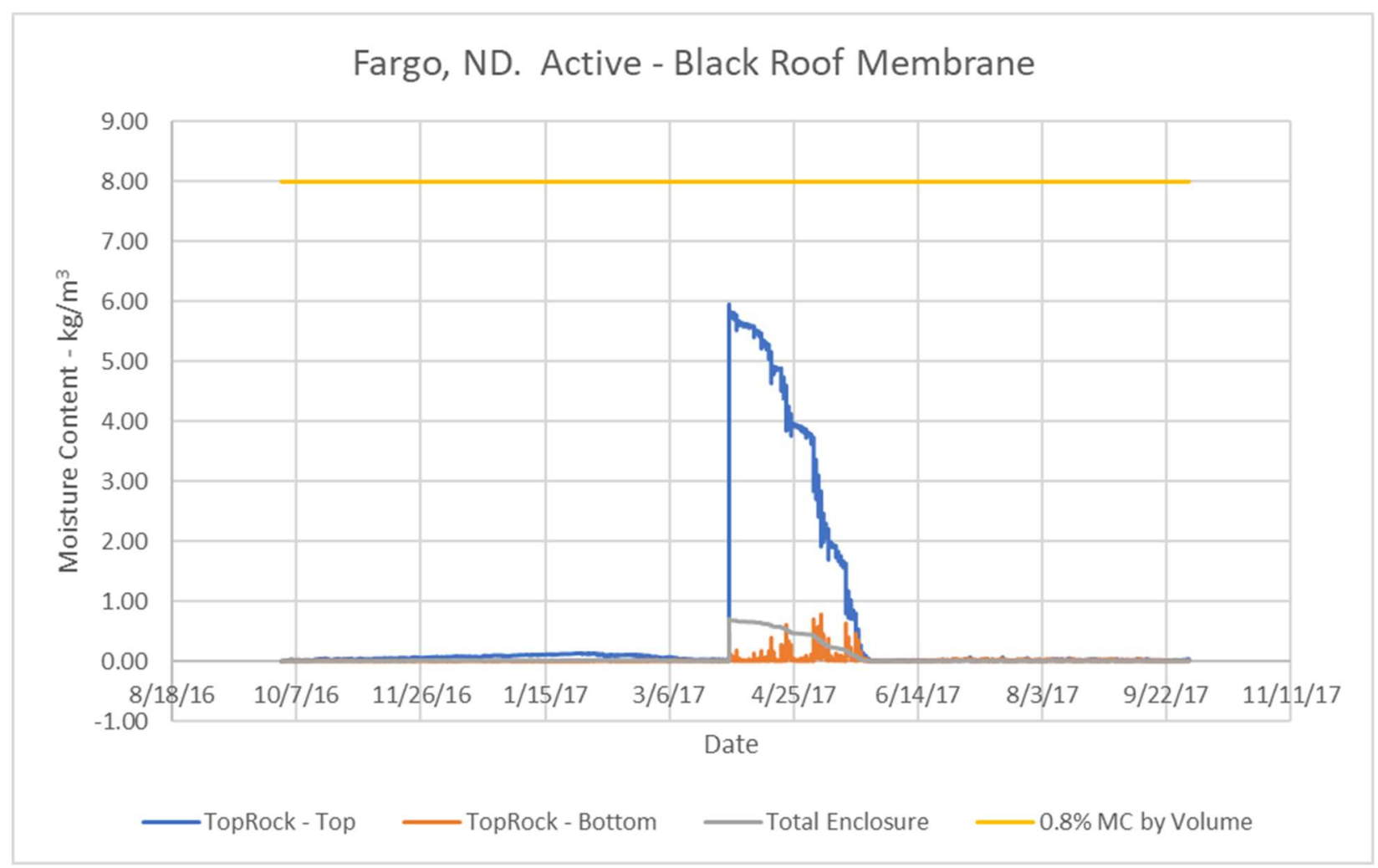



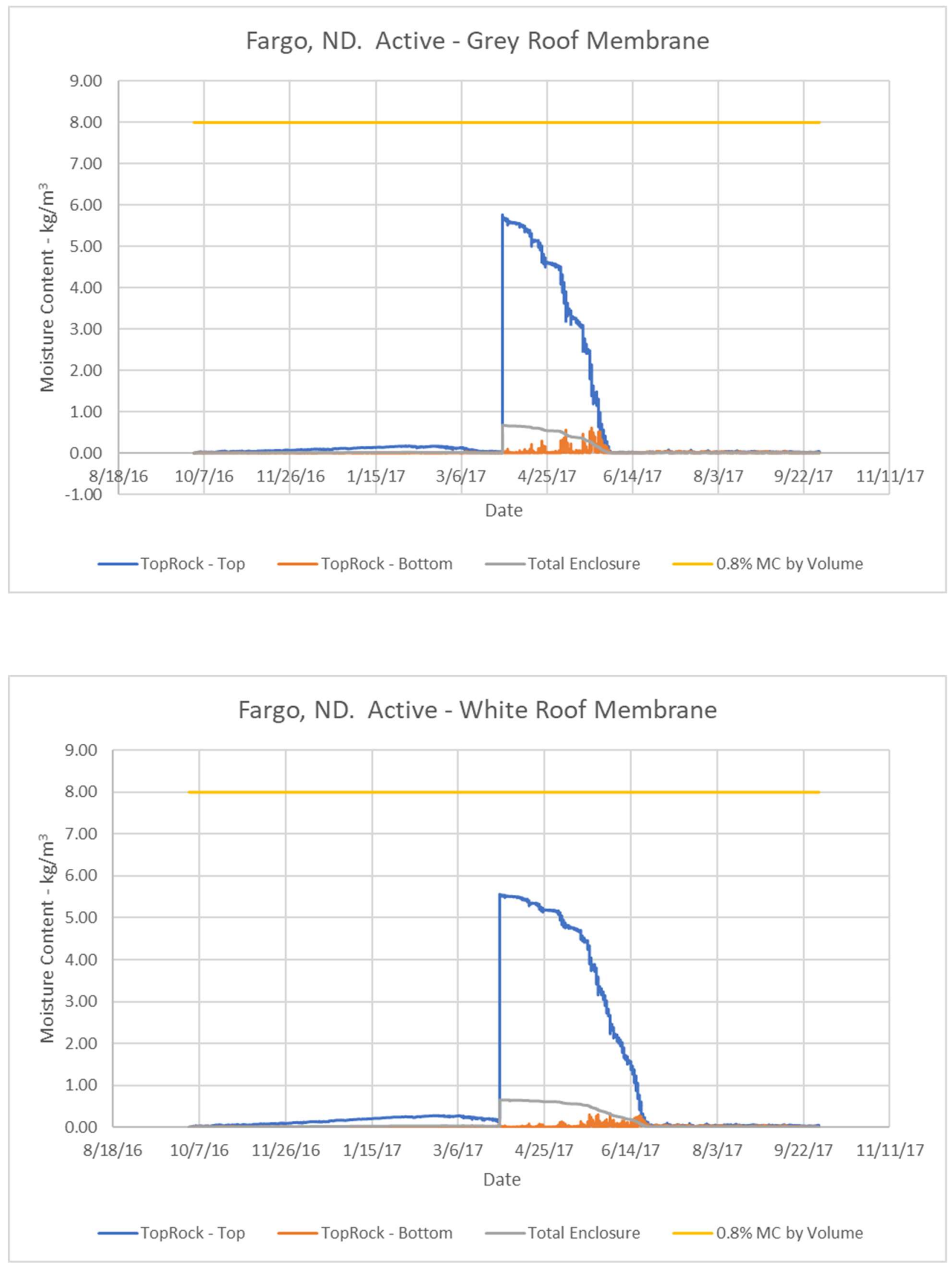
Houston, TX - Active
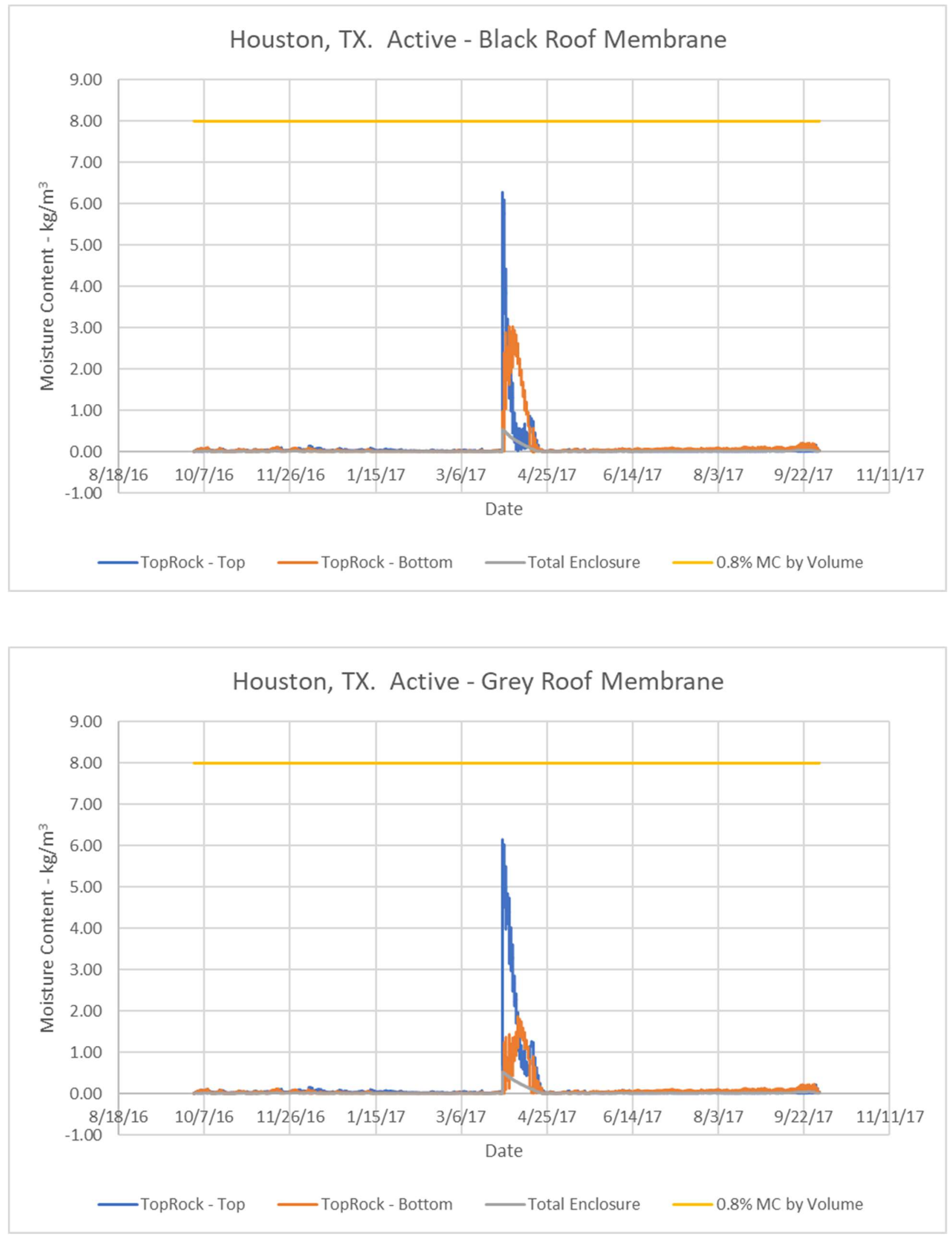


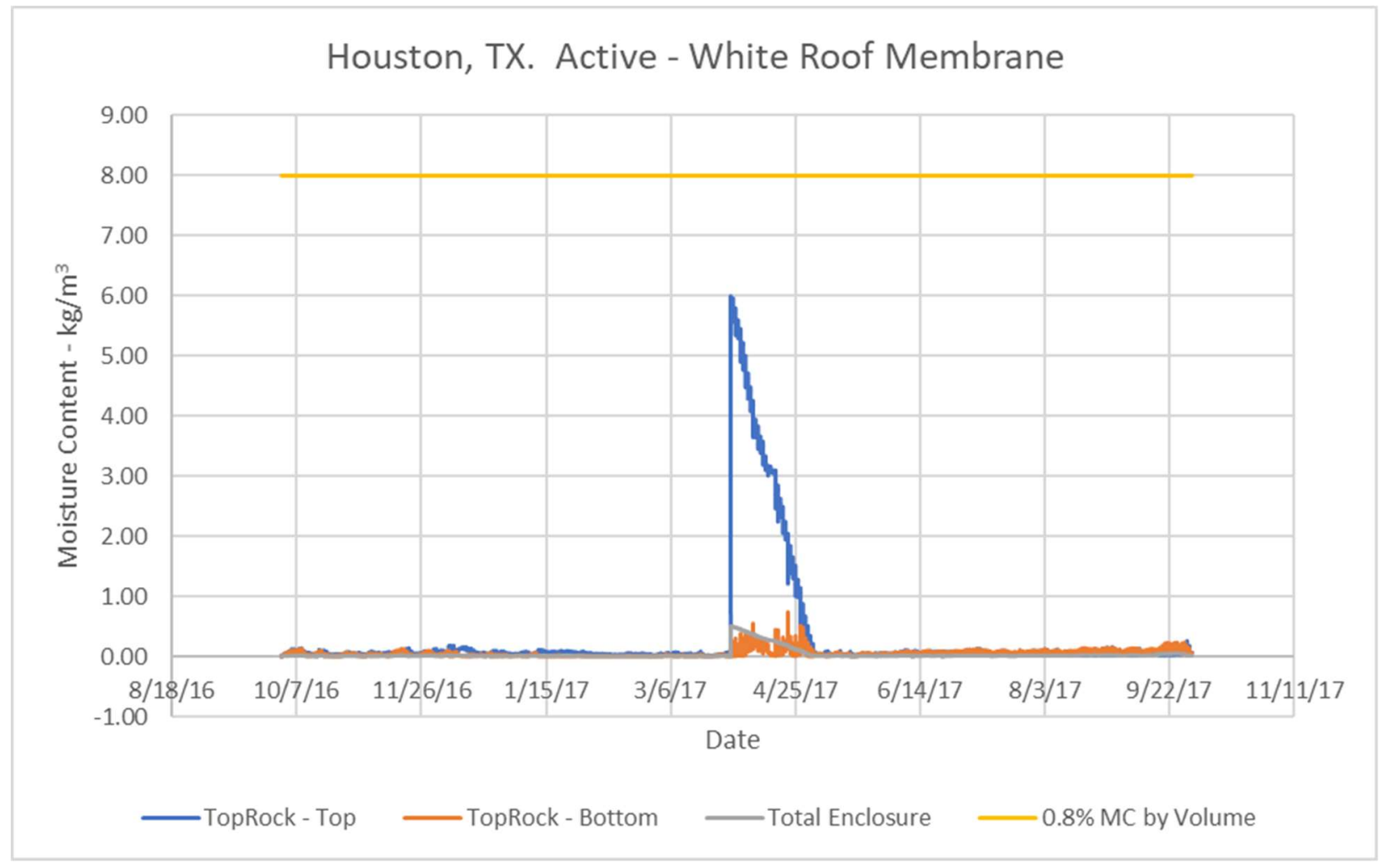

LOS ANGELES, CA - Active

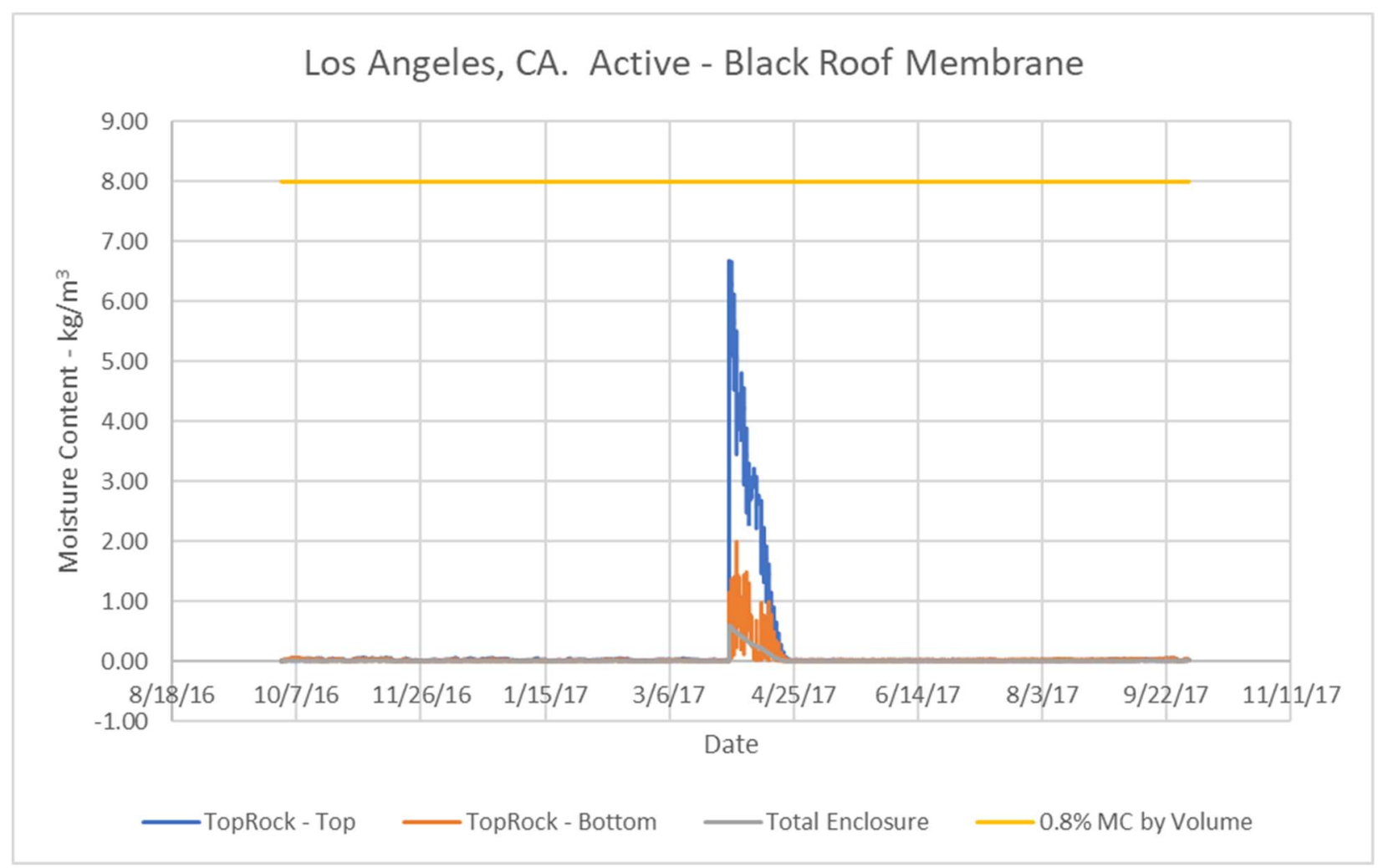



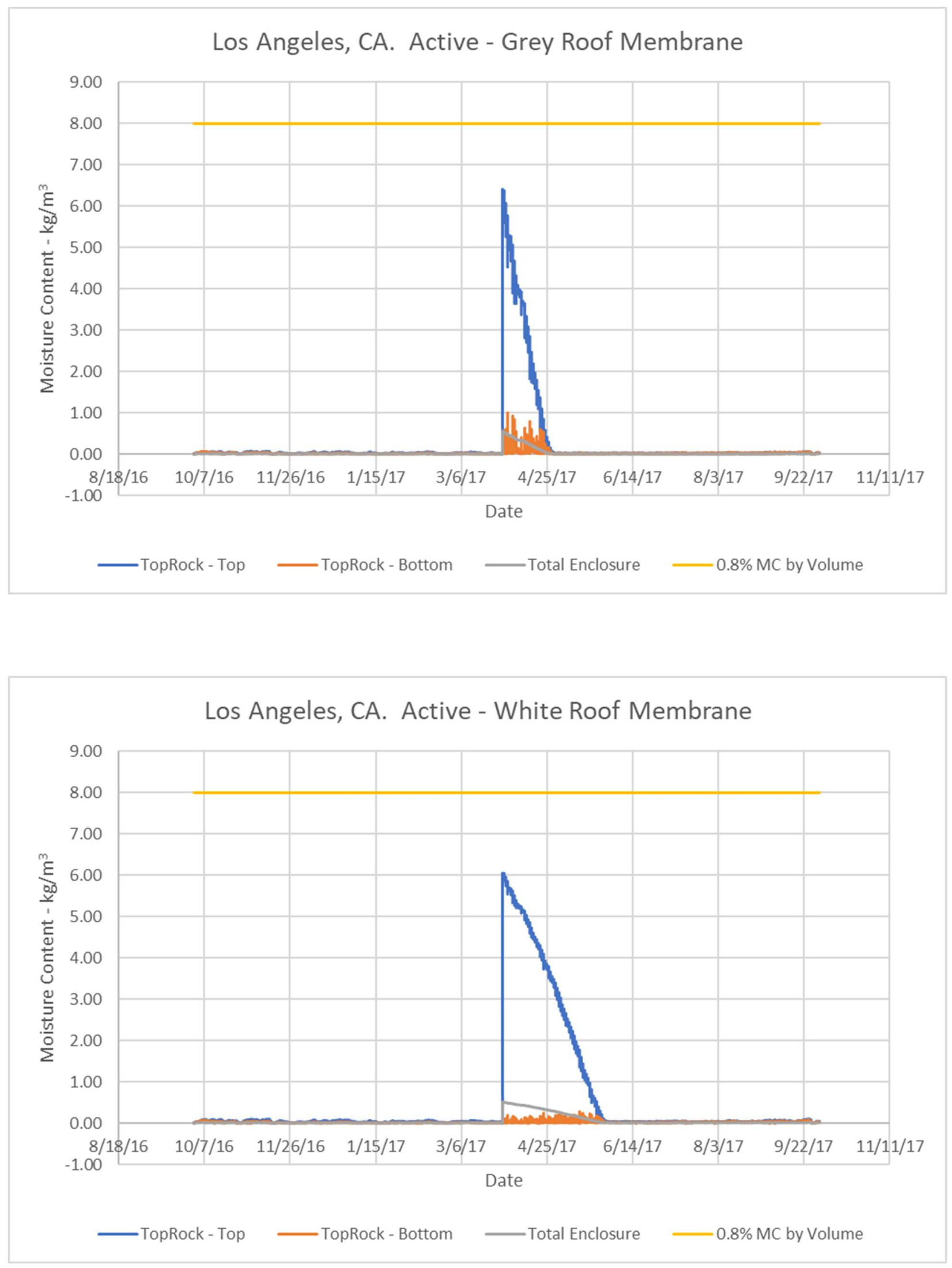




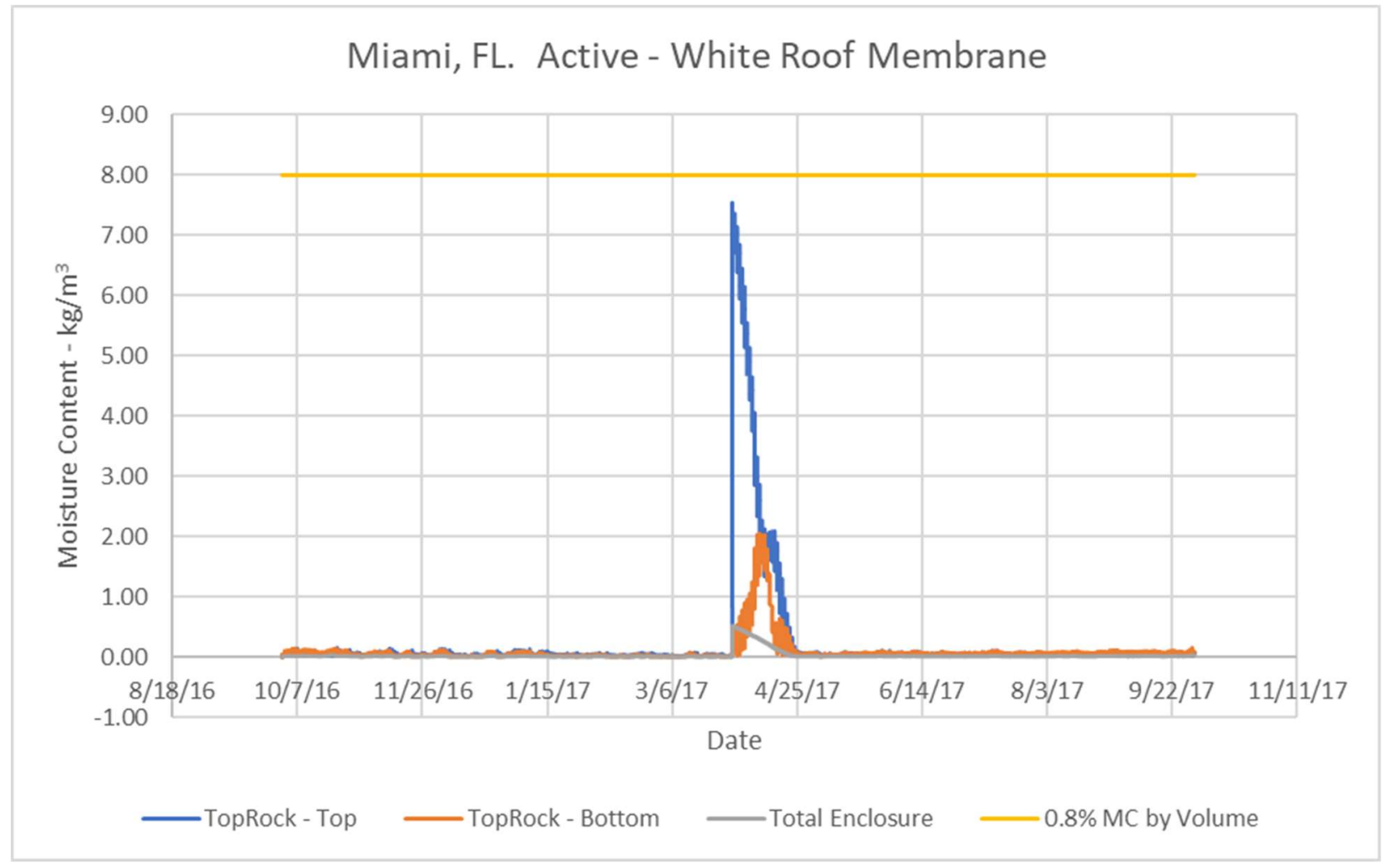

NEW YORK, NY - Active

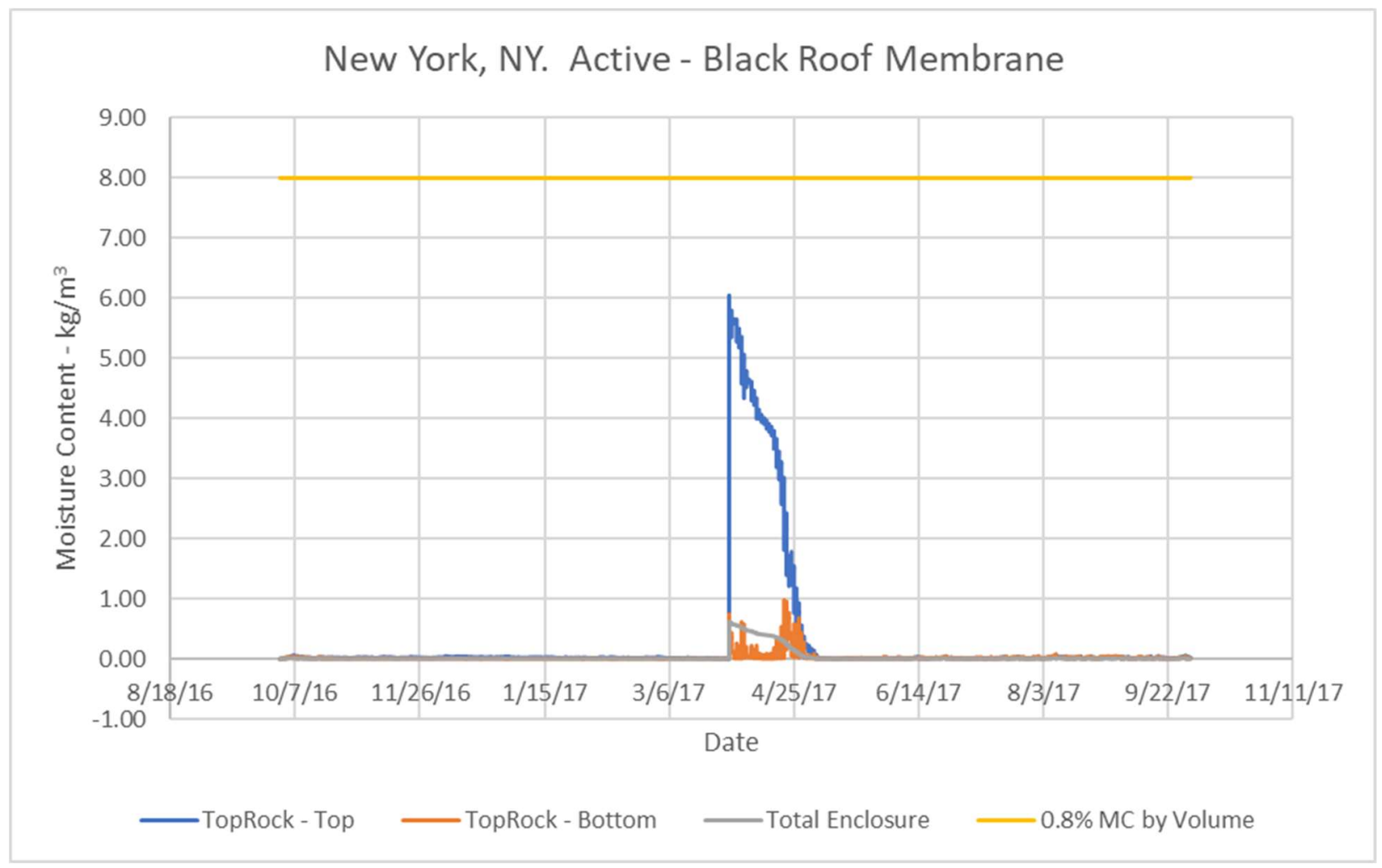



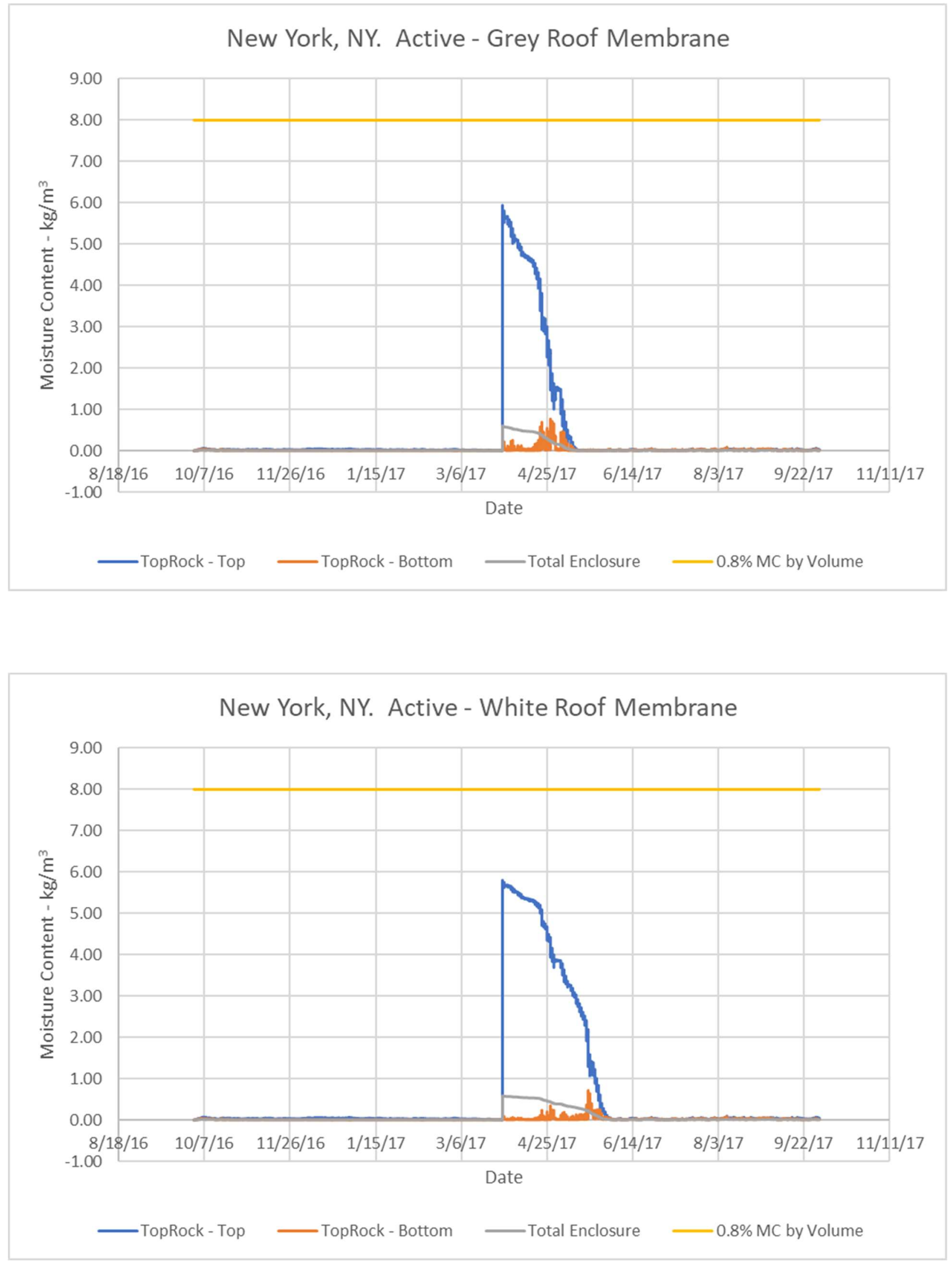